\title{
MUNICIPALIZAÇÃO DA SAÚDE E PODER LOCAL: SUJEITOS, ATORES E POLÍTICAS
}

SILVIO FERNANDES DA SILVA

Tese de Doutorado

apresentada ao

Departamento de Prática de Saúde Pública da Faculdade de Saúde Pública da Universidade de São Paulo para obtenção do grau de Doutor.

Área de concentração:

Administração Hospitalar

ORIENTADOR:

PROF. DR. MARCOS KISIL

São Paulo

2001 


\section{AGRADECIMENTOS}

Os meus sinceros agradecimentos a todos os que contribuíram, direta ou indiretamente, para a realização deste trabalho. Registro o meu agradecimento especial às seguintes pessoas, entidades e instituições:

Ao Prof. Dr. MARCOS KISIL, que, sempre atento às necessidades do orientando, soube dosar a influência e a sugestão com a autonomia e a liberdade. indicando as pistas e os caminhos mais seguros para o desenvolvimento deste estudo acadêmico.

Aos professores NELSON RODRIGUES DOS SANTOS e GASTÃO WAGNER DE SOUZA CAMPOS, da UNICAMP, e CARMEM VIEIRA DE SOUZA UNGLERT, da FSPIUSP, pela contribuição prestada durante a fase de elaboração do pré-projeto deste estudo. Suas informações tornaram mais claras as primeiras pistas que deveriam ser seguidas na delimitação do objeto de estudo.

Ao Prof. Dr. PEDRO ROBERTO FERREIRA, cientista político do Departamento de Ciências Sociais da Universidade Estadual de Londrina, pela leitura do pré-projeto do estudo e pelas sugestões oferecidas.

Ao Prof. Dr. RONALDO BALTAR, cientista político na Universidade do Departamento de Ciências Sociais da Universidade Estadual de Londrina, que em diferentes momentos colaborou com a realização do estudo. Sua orientação foi imprescindivel para reduzir um pouco das minhas dificuldades teóricas na análise de políticas e para dirimir muitas de minhas dúvidas. 
Aos professores PAULO ANTONIO DE CARVALHO FORTES e OSWALDO YOSHIMI TANAKA da FSP/USP pela disposição de ler esboços do projeto de estudos e pelas observações valiosas.

Ao secretário de saúde de Marilia, Dr. JOSÉ ÊNIO SERVILHA DUARTE, extensivo aos membros de sua assessoria, pela eficiência na disponibilização das informações necessárias para o estudo de caso.

A todas as pessoas que se dispuseram a ser entrevistados e a dedicar parte do seu tempo e do seu conhecimento para a execução deste estudo

É necessário registrar, e também agradecer aos envolvidos, o auxilio indireto que representou o convivio com os participantes de diversos sistemas municipais de saüde, nos quais desenvolvi algum tipo trabalho na área de saúde nos últimos quatro anos. Destacamos os municipios de Sorocaba e São Vicente, no estado de São Paulo, e Cascavel, Castro, Maringá, Ibiporã e Apucarana, no estado do Paraná. O contato rotineiro com gestores municipais e centenas de trabalhadores da área de saúde e usuários destes sistemas de saúde, permitiu que eu conhecesse melhor essas diferentes realidades, podendo melhor compará-las com a realidade empirica que estava sendo analisada.

Ao CNPq o meu reconhecimento por incluir-me em seu quadro de bolsistas no periodo de realização deste estudo.

Aos amigos e colegas que me encorajaram na desenvolvimento dos estudos e, em particular, ao amigo LUíS CARLOS YOSHIO SUGMYAMA, pelas críticas, sugestões e apoio.

Ao amigo e doutorando da Universidade de Dallas, PERCY ANTONIO GALIMBERTI CATANIO pelas sugestões e pela troca de idéias. 
Um agradecimento muito especial ao amigo e Prof. Dr. JOSÉ LUíS DA SILVEIRA BALDY, pela competente revisão de toda a tese. Ele, que eu já sabia ser uma referência imprescindivel para quem busca conhecimentos na área de doenças infecciosas, mostrou-se para mim um expert também em outra área: a língua portuguesa.

À minha familia, KEIKO, MIGUEL, FERNANDO E ADRIANO, pelo apoio e incentivo permanentes. 


\section{ÍNDICE}

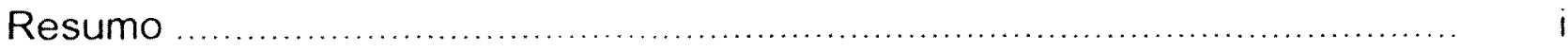

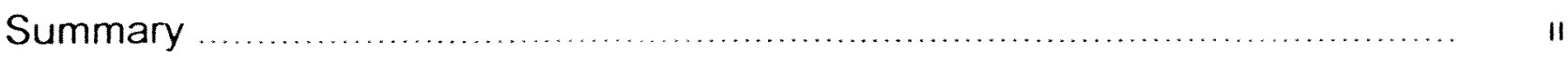

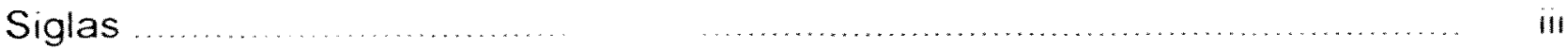

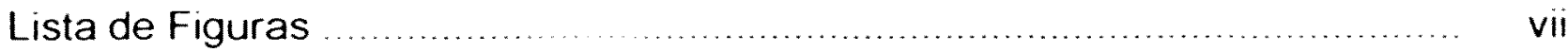

Lista de Tabelas ............ $\quad$ x

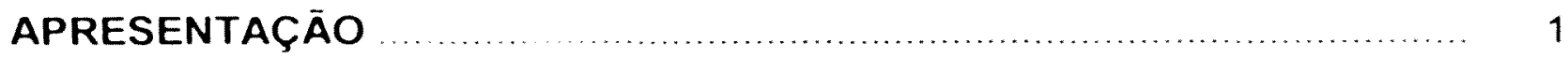

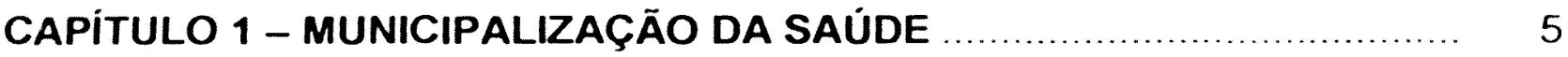

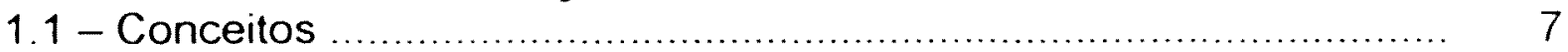

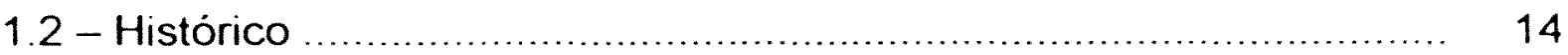

1.3 - Contexto recente do processo de municipalização da saúde .......... 41

CAPITULO 2 - PODER LOCAL ….................................................. 50

2.1 - Conceitos ..................................................................... 52

2.2 - Os governos locais: constrangimentos institucionais e legais ......... 54

2.3 - Poder local e representação de interesses ............................... 60

2.4 - Incongruências da Constituição Federal de 1988 no Brasil ............. 68

2.5 - A participação da sociedade na política .................................. 72

CAPITULO 3 - ASPECTOS METODOLÓGICOS …............................ 84

3.1 - Fundamentação teórica .................................................... 85

3.1.1 - Proposta hermenêutico-dialética ................................... 88

3.1.2 - Aspectos teóricos de análise de políticas públicas ............... 91

3.1 .3 - Planejamento e participação na gestão da saúde municipal ... 103

3.2 - Aspectos metodológicos do estudo empirico ............................ 106

3.2.1 - Particularidades do estudo de caso .............................. 106

3.2 .2 - Hipóteses ou pressupostos .......................................... 111

3.2 .3 - Categorias empíricas ............................................. 115

3.2.4 - Aspectos operacionais da análise de dados ...................... 116 
CAPITULO 4 - O PROCESSO DE MUNICIPALIZAÇÃO DA SAÚDE DE MARILIA - SP

4.1. - Considerações iniciais .............................................................. 123

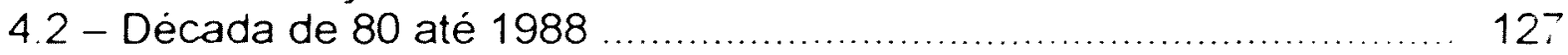

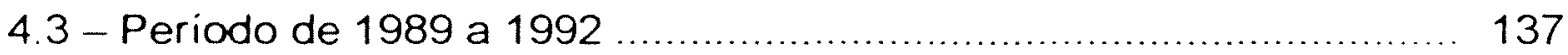

4.3.1 - Os governantes locais e os aliados do movimento sanitário percepções, interesses e contexto ............................................ 137

432 - O surgimento do Conselho Municipal de Saúde .................. 142

4.4 - Periodo de 1993 a 1996 ....................................................... 155

441 - Divergências, discordâncias e alianças entre os atores locais 156

4.42 - O Projeto UNI/Marilia ............................................... 161

4.4.3 - O Conselho Municipal de Saúde ….................................. 166

4.4.4 - Conselhos locais de saúde …....................................... 178

4.5 - Periodo de 1997 a 1999 .................................................... 191

4.5.1 - O município em condição de gestão plena do sistema municipal ........................................................................ 193

4.5.2 - A incorporação de novos atores ao sistema de decisões ....... 193

4.5.3 - O Conselho Municipal de Saúde em uma condição de maior autonomia de gestão ..................................................... 204

4.5.4 - Conselhos locais de saúde ......................................... 217

CAPITULO 5 - MUNICIPALIZAÇÃO DA SAÜDE: CONQUISTAS, OBSTÁCULOS NÃO-SUPERADOS E DESAFIOS PARA A NOVA AGENDA 227

5.1. A municipalização da saúde e o deslocamento de poder ................. 228

5.1.1 - O deslocamento de poder efetivamente ocorreu com a municipalização da saúde? ...................................................... 228

5.1 .2 - As politicas distributivas e redistributivas .......................... 232

5.1 .3 - As politicas regulatórias, a participação e o controle social .... 239

5.2. A municipalização da saúde e a liderança do processo de mudanças 246

5.3. A municipalização da saúde e as dificuldades de mudança do modelo assistencial

5.4. Os desafios para a nova agenda da descentralização da saúde ....... 259

5.5. Considerações finais ............................................................. 273

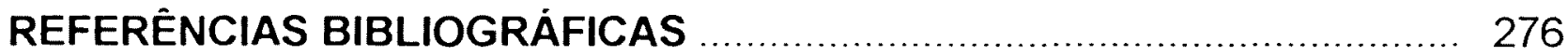

ANEXO 1: Informações sobre os entrevistados ...................................... 287 


\section{RESUMO}

Silva SF. Municipalização da saúde e Poder Local: Sujeitos, Atores e Políticas. São Paulo; 2000. [Tese de Doutorado - Faculdade de Saúde Pública da USP].

Este trabalho analisa como estão sendo implantadas as políticas locais de saúde após o advento da municipalização da saúde no Brasil. A análise dá ênfase à percepção e ao comportamento dos atores locais da saúde, ao processo decisório e aos fatores que levam ao sucesso ou ao insucesso na implementação das politicas adotadas. A metodologia foi fundamentada pela investigação do encontro entre as duas categorias de análise centrais do estudo - municipalizaçăo da saúde e poder local - com o sistema de decisões das politicas de municipalização. A categoria empirica - sistema de decisōes - foi construida a partir de estudo de caso realizado em Marilia-SP Este estudo concluiu que o deslocamento de poder propiciado pela municipalização da saúde tem permitido avanço seletivo e diferenciado na formulação e na implementação das políticas de saúde. Esse avanço tem sido maior em relação a algumas políticas - classificadas como distributivas, redistributivas próprias do setor saúde ou regulatórias no seu sentido formal - e pequeno ou nulo em relação a outras, tais como as que implicam em alguma redistribuição fora do campo do setor saúde, mas ligadas ao processo saúde-doença, e regulatórias, que implicam em participação mais decisiva dos atores não-governamentais no processo decisório. O estudo também conclui que, através dessa percepção, podem ser buscadas pistas para estabelecer limites e possibilidades para o poder local. Além disso, o estudo chama a atenção para dois aspectos que interferem nas possibilidades de melhoria dos sistemas de saúde por intermédio de sua municipalização. $O$ primeiro diz respeito às características de liderança necessárias para impulsionar as mudanças nesse ambiente de governabilidade restrita dos espaços locais. O segundo refere-se aos reflexos das insuficiências teóricas da Reforma Sanitária, nas experimentações de modelos assistenciais alternativos nos municípios, apontando para a necessidade de aperfeiçoamento das estratégias de substituição do modelo hegemônico.

Descritores: Municipalização da saúde. Poder local. Processo decisório. Descentralização de políticas públicas. 


\section{SUMMARY}

Silva SF. The municipalization of the health and the Local Power: Subjects, Actors and Policies. São Paulo; 2000 [doctorate theses - Public Health College off USP].

This work analyzes the health policies implementation at local level after the regulation and implementation of the municipalization process in Brazil. The analysis emphasizes the perception and the behavior of the local actors, the decision-making process, and the factors that lead to succeed or to fail in the implementation of the adopted policies. The methodology was based on the investigation of the interaction between both central categories of analysis of this study -health municipalization and local power - and the policies decision-making system regarding the process of municipalization. The empirical category -the decision-making system- was built based on case study conducted in the city of Marilia (São Paulo State). This study concludes that the displacement of power propitiated by the health municipalization has allowed selective and different levels of advance in the formulation and implementation of health policies. The advance has been bigger for some policies -classified as distributive, re-distributive proper from the health section, or formally regulative-, and little or null for others, such as those involving some re-distribution out of the health field but connected to the health-illness process, and regulative, which implicate in a more decisive participation of the non-governmental actors in the decision-making process. The study also concludes that through this perception clues may be found to establish limits and possibilities to the local power. The study also calls attention for two aspects that interfere on the possibilities of health systems improvement mediated by the municipalization. The first is about the features of leadership necessary to conduct the changes in an environment of restricted governance of local areas. The second refers to the theoretic insufficiencies of the Sanitary Reform about the experimentation of alternative models of health assistance in municipalities, demonstrating the need for improvement of the strategies devoted to the replacement of the hegemonic model

Descriptors: Health municipalization. Local power. Decision-Making process. Decentralization of public policies. 


\section{SIGLAS}

$\mathrm{ABH}$

ABRAMGE

ABRASCO

ACS

AlHs

APS

CEBES

CENDE S

CES

CIB

CIMS

CIPLAN

CIS

CIT

CLIS

CLS

CMS

CNS

COMUS

CONASEMS

CONASP
Associação Brasileira de Hospitais

Associação Brasileira de Medicina de Grupo

Associação Brasileira de Pós-Graduação em Saúde Coletiva

Agente comunitário de saúde

Autorizações de Internações Hospitalares

Atenção primária à saúde

Centro Brasileiro de Estudos da Saúde

Centro de Estudos de Desenvolvimento Econômico e Socıal

Conselho Estadual de Saúde

Comissão Intergestores Bipartite

Comissão Interinstitucional Municipal de Saúde

Comissão Interinstitucional de Planejamento

Comissão Interinstitucional de Saúde

Comissão Intergestores Tripartite

Comissão Interinstitucional Local de Saúde

Conselho Local de Saúde

Conselho Municipal de Saúde

Conselho Nacional de Saúde

Conselho Municipal de Saúde (de Marília)

Conselho Nacional dos Secretários Municipais de Saúde

Conselho Consultivo da Administração da Saúde Previdenciária

CONASS Conselho Nacional de Secretários Estaduais de Saúde 
CRIS Comissão Interinstitucional Regional de Saúde

CS Centro de Saúde

CS Escola - Centro de Saúde Escola

DIR Direção Regional de Saúde

DRS Departamento Regional de Saúde

ENSP Escola Nacional de Saúde Pública

ERSA Escritório Regional de Saúde

EUA Estados Unidos da América do Norte

FAMEMA Faculdade de Medicina de Marilia

FBH Federação Brasileira de Hospitais

FES Fundo Estadual de Saúde

FIOCRUZ Fundação Instituto Oswaldo Cruz

FMS Fundo Municipal de Saúde

FNS Fundo Nacional de Saúde

FUMES Fundação Municipal de Ensino Superior de Marilia

GED/MS Grupo Especial para a Descentralização do Ministério da Saúde

GERUS Desenvolvimento Gerencial de Unidades Básicas de Saúde no Distrito Sanitário

GIHs Guias de Internações Hospitalares

GPABA Gestão Plena da Atenção Básica Ampliada

HC Hospital de Clínicas

IBAM Instituto Brasileiro de Administração Municipal

INAMPS Instituto Nacional de Assistência Médica da Previdência Social

MARE

Ministério da Administração e Reforma do Estado 
MEC

MPAS

MS

NOAS

NOB SUS Norma Operacional Básica do Sistema Único de Saúde

ONGS

OPAS

PAB

PACS

PAM

PAS

PCCN

PDI

PDR

PDS

PIASS

PMDB

PMS

POI

PPI

PREV-SAÚDE Programa Nacional de Serviços Básicos de Saúde

PSF

Programa de Saúde da Familia

SADT
Ministério da Educação e Cultura

Ministério da Previdência e Assistência Social

Ministério da Saúde

Norma da Assistência à Saúde

Organizações não-governamentais

Organização Pan-Americana de Saúde

Piso da Atenção Básica

Programa de Agentes Comunitários de Saúde

Posto de Atendimento Médico

Pronto Atendimento em Saúde

Programa de Combate às Carências Nutricionais

Plano Diretor de Investimentos

Plano Diretor de Regionalização

Partido Democrático e Social

Programa de Interiorização das Ações de Saúde e Saneamento

Partido do Movimento Democrático Brasileiro

Plano Municipal de Saúde

Programação e Orçamentação Integrada

Programação Pactuada e Integrada 
SES

SILOS

SIM

SINAM

SINASC

SUDS

SUS

UBS

UNI

UNIMAR

URRS

USP
Secretaria Estadual de Saúde

Sistemas Locais de Saúde

Sistema de Informações em Mortalidade

Sistema de Informações de Agravos de Notificação de Vigilância Epidemiológica

Sistema de Informação de Nascidos Vivos

Sistema Unificado e Descentralizado de Saúde

Sistema Único de Saúde

Unidade Básica de Saúde

Uma Nova Iniciativa na Educação dos Profissionais de Saúde União com a Comunidade

Universidade de Marilia

União das Repúblicas Socialistas Soviéticas

Universidade de São Paulo 


\section{LISTA DE FIGURAS}

Figura 1 - Arenas de poder, com exemplos relativos a políticas puras e mistas.

Figura 2 - Localização do município de Marilia 105

Figura 3 - Esquema do sistema político e seu vínculo com o sistema social.

Figura 4 Comparação entre as freqüências dos assuntos que surgiram nas reuniões do Conselho Municipal de Saúde, nos periodos de 1991 a 1992 e 1993 a 1996 - Marilia-SP $(\mathrm{em} \%)$

Figura 5 Comparação entre as freqüências com que os governos federal/estadual e o governo local trouxeram assuntos gerenciais e assistenciais relacionados a mudanças de infra-estrutura e do modelo assistencial às reuniōes do Conselho Municipal de Saúde, períodos de 1991-1992 e de 1993-1996 - Marilia-SP (em \%)

Figura 6 - Comparação entre as freqüências do destino dado aos assuntos gerenciais e assistenciais relacionados a mudanças de infra-estrutura e do modelo assistencial que surgiram nas reuniões do Conselho Municipal de Saúde, nos períodos de 1991-1992 e de 1993-1996 - Marilia-SP $(\mathrm{em} \%)$

Figura 7 - Comparação entre as freqüencias dos assuntos gerenciais e assistenciais relacionados a mudanças de infra-estrutura e do modelo assistencial priorizados (implementados) que surgiram nas reuniões do Conselho Municipal de Saúde por influência dos governos federal/estadual e governo local, nos periodos de 19911992 e 1993-1996 - Marilia-SP (em \%)

Figura 8 - Comparação entre as freqüências com que os usuários e prestadores de serviço trouxeram assuntos ligados a reclamações sobre qualidade da assistência ou sobre remunerações dos serviços nas reuniões do Conselho Municipal de Saúde, nos períodos de 1991-1992 e 19931996 - Marilia-SP (em \%) 
Figura 9 - Comparação sobre o destino dado às reclamações sobre qualidade da assistência ou sobre remuneração dos serviços que surgiram nas reuniões do Conselho Municipal de Saúde, nos periodos de 1991-1992 e 19931996 - Marília-SP (em \%)

Figura 10 - Comparação entre a freqüência com que os governos federal/estadual e o governo local trouxeram assuntos relacionados à ampliação ou aperfeiçoamento do controle social nas reuniões do Conselho Municipal de Saúde nos períodos de 1991-1992 e 1993-1996 - Marilia-SP (em \%)

Figura 11 - Comparação sobre o destino dado aos assuntos relacionados à ampliação ou aperfeiçoamento do controle social que surgiram nas reuniōes do Conselho Municipal de Saúde nos periodos de 1991-1992 e 1993-1996 Marilia-SP (em \%)

Figura 12 - Comparação entre as freqüências dos assuntos que surgiram nas reuniões do Conselho Municipal de Saúde, nos períodos de 1991 a 1992, 1993 a 1996 e 1997 a 1999 - Marilia-SP (em \%)

Figura 13 - Comparação entre as freqüências com que os governos federal/estadual e o governo local trouxeram assuntos gerenciais e assistenciais relacionados a mudanças de infra-estrutura e do modelo assistencial às reuniões do Conselho Municipal de Saúde, períodos de 1991 a 1992, 1993 a 1996 e 1997 a 1999 - Marilia-SP (em \%)

Figura 14 - Comparação entre as freqüências dos destinos dados aos assuntos gerenciais e assistenciais relacionados a mudanças de infra-estrutura e do modelo assistencial que surgiram nas reuniōes do Conselho Municipal de Saúde períodos de 1991-1992, 1993-1996 e 1997-1999 - Marília $\mathrm{SP}(\mathrm{em} \%)$

Figura 15 - Comparação entre as freqüências dos destinos dados aos assuntos gerenciais e assistenciais relacionados a mudanças de infra-estrutura e do modelo assistencial que surgiram nas reuniões do Conselho Municipal de Saúde, periodos de 1991 a 1992, 1993 a 1996 e 1997 a 1999 Marilia-SP (em \%) 
Figura 16 - Comparação entre as freqüências dos destinos dados aos assuntos relacionados à ampliação ou aperfeiçoamento do controle social que surgiram nas reuniões do Conselho Municipal de Saúde nos períodos de 1991 a 1992, 1993 a 1996 e 1997 a 1999 - Marília-SP (em \%)

Figura 17 - Comparação entre as freqüências com que os usuários e os prestadores de serviço trouxeram reclamações sobre a qualidade da assıstência ou sobre a remuneração dos serviços prestados às reuniōes do Conselho Municipal de Saúde, períodos de 1991 a 1992, 1993 a 1996 e 1997 a 1999 - Marilia-SP (em \%)

Figura 18 - Comparação entre as freqüências com que os usuários e os prestadores de serviço trouxeram reclamaçōes sobre a qualidade da assıstência ou sobre a remuneração dos serviços prestados nas reuniöes do Conselho Municipal de Saúde, nos anos de 1997,1998 e 1999 - Marilia-SP (em \%)

Figura 19 - Comparação entre as freqüências dos destinos dados às reclamações sobre a qualidade da assistência ou sobre a remuneração dos serviços que surgiram nas reuniões do Conselho Municipal de Saúde, nos períodos de 1991 a 1992, 1993 a 1996 e 1997 a 1999 - Marilia-SP (em \%) ....

Figura 20 - Relação entre a capacidade de implementação de políticas distributivas e redistributivas e o deslocamento de poder propiciado pela municipalização da saúde

Figura 21 - Relação entre a ampliação da autonomia de gestão e o comportamento das políticas distributivas e redistributivas em municipios que simplesmente reproduzem o modelo de saúde vigente

Figura 22 - Triângulo de governo de Matus

Figura 23 - Organização da atenção e modelos assistenciais hegemônicos e alternativos 


\section{LISTA DE TABELAS}

Tabela 1 - Assuntos que entraram na agenda do Conselho Municipal de Saúde nos anos de 1991 e 1992 - MariliaSP

Tabela 2 - Distribuição dos assuntos gerenciais e assistenciais discutidos nas reuniōes do Conselho Municipal de Saúde nos anos de 1991 e 1992 - Marilia-SP

Tabela 3 - Fatores que tornaram relevantes os informes referentes a assuntos gerenciais e assistenciais transmitidos no Conselho Municipal de Saúde, nos anos de 1991 e 1992, em Marilia-SP

Tabela 4 - Fatores que tornaram relevantes os assuntos ligados a mudanças de infra-estrutura e do modelo assistencial discutidos no Conselho Municipal de Saúde, nos anos de 1991 e 1992, em Marilia-SP

Tabela 5 - Destino dado aos assuntos ligados a mudanças de infraestrutura e do modelo assistencial que entraram na agenda do Conselho Municipal de Saúde nos anos de 1991 e 1992 - Marilia-SP

Tabela 6 - Fatores que tornaram relevantes os assuntos relacionados às reclamaçōes sobre qualidade da assistência ou sobre remuneração dos serviços discutidas no Conselho Municipal de Saúde, nos anos de 1991 e 1992, em Marilia-SP

Tabela 7 - Destino dado às reclamações sobre qualidade da assistência ou sobre remuneração dos serviços que entraram na agenda do Conselho Municipal de Saúde nos anos de 1991 e 1992 - Marilia-SP

Tabela 8 - Fatores que tornaram relevantes os assuntos relacionados à ampliação ou aperfeiçoamento do controle social discutidas no Conselho Municipal de Saúde, nos anos de 1991 e 1992, em Marilia-SP

Tabela 9 - Destino dado aos assuntos relacionados à ampliação ou aperfeiçoamento do controle social que entraram na agenda do Conselho Municipal de Saúde nos anos de 1991 e 1992 - Marília-SP 
Tabeia 10 - Assuntos que entraram na agenda do Conselho Municipal de Saúde no período de1993 a 1996 - MariliaSP.

Tabela 11 - Distribuição dos assuntos gerenciais e assistenciais que surgiram nas reuniões do Conselho Municipal de Saúde, no período de 1993 a 1996 - Marília-SP.

Tabela 12 - Fatores que tornaram relevantes os informes referentes a assuntos gerenciais e assistenciais discutidos no Conselho Municipal de Saúde, nos anos de 1993 a 1996, em Marilia-SP

Tabela 13 - Fatores que tornaram relevantes os assuntos ligados a mudanças de infra-estrutura e do modelo assistencial discutidos no Conselho Municipal de Saúde, no periodo de 1993 e 1996, em Marilia-SP

Tabela 14 - Destino dado aos assuntos ligados a mudanças de infraestrutura e do modelo assistencial que entraram na agenda do Conselho Municipal de Saúde, no periodo de 1993 a 1996 - Marilia-SP

Tabela 15 - Fatores que tornaram relevantes os assuntos relacionados às reclamações sobre qualidade da assistência ou sobre remuneração dos serviços, discutidas no Conselho Municipal de Saúde, no periodo de 1993 a 1996 - Marilia-SP

Tabela 16 - Destino dado às reclamações sobre qualidade da assistência ou sobre remuneração dos serviços que entraram na agenda do Conselho Municipal de Saúde, no periodo de 1993 a 1996 - Marilia-SP

Tabela 17 - Fatores que tornaram relevantes os assuntos relacionados à ampliação ou aperfeiçoamento do controle social discutidas no Conselho Municipal de Saúde, no periodo de 1993 a 1996 - Marilia-SP

Tabela 18 - Destino dado aos assuntos relacionados à ampliação ou aperfeiçoamento do controle social que entraram na agenda do Conselho Municipal de Saúde, no período de 1993 a 1996 - Marilia-SP 
Tabela 19 - Número de reuniões e de assuntos discutidos nas reuniões dos Conselhos Locais de Saúde de 7 (sete) Unidades de Saúde no período de 1993 a 1996 Marilia-SP

Tabela 20 - Distribuição dos assuntos que surgiram nas reuniōes dos CLS das UBS Santa Antonieta, São Judas, Bandeirantes, Altaneira, Vila Coimbra, Aeroporto e Castelo Branco, realizadas no período de 1993 a 1996 Marilia-SP

Tabela 21 - Assuntos que entraram na agenda do Conselho Municipal de Saúde. no periodo de1997 a 1999 Marilia-SP

Tabela 22 - Distribuição dos assuntos gerenciais e assistenciais que surgiram nas reuniões do Conselho Municipal de Saúde, no periodo de 1997 a 1999 - Marilia-SP

Tabela 23 - Fatores que tornaram relevantes os informes referentes a assuntos gerenciais e assistenciais discutidos no Conselho Municipal de Saúde, no periodo de 1997 a 1999, em Marilia-SP

Tabela 24 - Fatores que tornaram relevantes os informes referentes a assuntos gerenciais e assistenciais discutidos no Conselho Municipal de Saúde, no periodo de 1997 a 1999, em Marília-SP

Tabela 25 - Destino dado aos assuntos ligados a mudanças de infraestrutura e do modelo assistencial que entraram na agenda do Conselho Municipal de Saúde, no periodo de 1997 a 1999 - Marilia-SP

Tabela 26 - Fatores que tornaram relevantes os assuntos relacionados à ampliação ou ao aperfeiçoamento do controle social discutidos no Conselho Municipal de Saúde, no período de 1997 a 1999, em Marília-SP

Tabela 27 - Destino dado aos assuntos relacionados à ampliação ou ao aperfeiçoamento do controle social que entraram na agenda do Conselho Municipal de Saúde, no período de 1997 a 1999 - Marília-SP 
Tabela 28 - Fatores que tornaram relevantes os assuntos relacionados às reclamações sobre qualidade da assistência ou sobre remuneração dos serviços discutidos no Conselho Municipal de Saúde, no período de 1997 a 1999, em Marília-SP

Tabela 29 - Destino dado às reclamações sobre qualidade da assistência ou sobre remuneração dos serviços que entraram na agenda do Conselho Municipal de Saúde, no periodo de 1997 a 1999 - Marilia-SP

Tabela 30 - Número de reuniōes e de assuntos discutidos nas reuniões dos Conselhos Locals de Saúde de sete Unidades de Saúde, no periodo de 1997 a 1999 Marilia-SP

Tabela 31 - Distribuição dos assuntos que surgiram nas reuniões dos CLS das UBS Santa Antonieta, São Judas, Bandeirantes, Altaneira, Vila Coimbra, Aeroporto, Castelo Branco, realizadas no periodo de 1997 a 1999 Marilia-SP

Tabela 32 - Distribuição dos assuntos que surgiram nas reuniões dos CLS das UBS Santa Antonieta, São Judas, Bandeirantes, Altaneira, Vila Coimbra, Aeroporto, Castelo Branco, realizadas nos periodos de 1993 a 1996 e 1997 a 1999 - Marilia-SP 


\section{APRESENTAÇÃO}

Neste trabalho preocupou-nos investigar de que forma são utilizados os diferentes recursos relacionados à municipalização da saúde. Não nos referimos aqui apenas aos recursos econômicos mas também, de forma particular, aos recursos políticos, ou seja aos recursos de poder. Como nos mostra Matus (HUERTAS $\left.{ }^{56}, 1996\right)$, para viabilizar as ações de governo é, as vezes, indispensável, a disponibilidade de recursos econômicos; outras vezes basta saber utilizar adequadamente os recursos de poder já existentes

Essas alternativas suscitam reflexões sobre poder e governo e sua relação com o processo de municipalização da saúde em curso no Brasil, já que esse processo ocorre em ambiente onde interagem distintos atores sociais, no qual os responsáveis pela implementação do SUS têm a responsabilidade de administrar conflitos, negociando mudanças no sistema de saúde. No entanto, como afirma Matus, nem tudo é redutível à negociação. Deve-se negociar, quando necessário; no entanto, muitas vezes os responsáveis pela execução das politicas devem impor operações conflitivas, utilizando os recursos de poder de que dispõem.

Com a preocupação de compreender melhor como se dá o exercício do poder de governo e de como se comportam os diferentes atores e personagens da municipalização da saúde, procuramos elaborar projeto de estudo, que valoriza os conceitos relacionados com o poder local e com o ato de governar e de liderar processos de mudança.

Nossa opção metodológica exigiu, primeiramente, que duas categorias de análise - municipalização da saüde e poder local - fossem desenvolvidas, o que fizemos nos dois primeiros capitulos deste trabalho. 
No capítulo 1 expusemos e analisamos os conceitos, o histórico e o contexto em que se processa a municipalização da saúde, procurando ressaltar as duas diferentes racionalidades politicas que estão envolvidas com o movimento descentralizatório.

O Movimento Sanitário brasileiro participa de uma dessas racionalidades; a análise de seu percurso permite conhecer os valores e os interesses com os quais está identificado esse movimento.

A descentralização das políticas sociais, entre as quais a da saúde, num contexto político em que o ajuste das contas públicas ocupa posição prioritária na agenda dos governantes, constitui a outra racionalidade. Esta é impulsionada por valores e interesses ligados a políticas de ajuste fiscal e de reforma do Estado. Entendemos que ambas devem ser consideradas na análise da politica de municipalização da saúde.

No capitulo 2 tivemos como objetivo analisar como se expressam os distintos interesses no âmbito do poder local e os fatores - constitucionais, legais e financeiros - que constrangem os governantes locais para o desenvolvimento de seus projetos de governo. Além disso, procuramos verificar como tem se processado a participação da população brasileira no setor saúde, na história recente, em particular depois de promulgadas a Constituição de 1988 e a Lei Orgânica da Saúde, com o advento dos Conselhos de Saúde.

No desenvolvimento do projeto de pesquisa, que começou com entrevistas exploratórias abertas com pesquisadores da UNICAMP e USP, procurou-se inicialmente identificar pistas que facilitassem a delimitação do objeto de estudo; uma vez conhecidas, optamos pela investigação que nos possibilitasse a análise do deslocamento de poder propiciado pela municipalização da saúde. 
A opção de articulação metodológica que permitisse confrontar as categorias de análise centrais do estudo com os dados empíricos é tema do capitulo 3. Um dos referenciais utilizados foi o de análise de políticas, dando ênfase a temas como agenda decisória, classificação de políticas, processo decisório e sistema de decisões. Este último foi escolhido como categoria empirica principal, pois entendemos que é a partir da identificação e investigação de como se processam as decisões nos espaços concretos de implantação da política de municipalização que poderão surgir pistas para o desenvolvimento da análise proposta.

Os pressupostos deste estudo, também apresentados no capítulo 3, dizem respeito basicamente aos limites e às possibilidades do poder local para por em prática as políticas de interesse do SUS, ao reflexo das fraglidades conceituais da Reforma Sanitária, nos espaços concretos em que ela procura se materializar, e à dependência que tem a municipalização da saúde de "sujeitos de mudança" com determinado perfil, mais adequado para dar inicio às modificações preconizadas pela Reforma, em âmbito local.

O capítulo 4 trata da investigação empírica. Optou-se por estudar o municipio de Marília SP - local onde se desenvolveu o estudo de caso - em diferentes periodos de governo. O periodo de estudo abrangeu desde o inicio da municipalização da saúde, nos primeiros anos da década de 1980, até a vigência da gestão plena do sistema municipal, no final da década de 1990. Procuramos coletar informações de todos os potenciais fóruns decisórios das políticas de saúde - governo formal, conselhos de saúde, elementos de poder real etc. - para conhecer como se processam as decisões.

A análise dos resultados e as conclusões do estudo são apresentadas no capítulo 5, no qual procuramos mostrar as repercussões da ampliação do deslocamento de poder que se observou nos sucessivos períodos estudados e sua influência na implementação das políticas de saúde e no controle 
social. Optamos por distinguir as politicas distributivas e as redistributivas, utilizando o esquema de Lowi, apresentado no capítulo 3. Foram tratadas diferentemente as políticas redistributivas setoriais - próprias do setor saúde - das politicas redistributivas extra-setoriais, consideradas por nós como aquelas ligadas às condições de vida. Distinguiu-se também o controle social formal, representado pela institucionalização dos conselhos de saúde, de um controle social mais substantivo, em que os atores locais de fato se apropriam de parte do poder de decidir.

No fim deste quinto e último capitulo, fazemos algumas reflexões que consideramos oportunas, a serem incorporadas à agenda de mudanças exigidas pelo processo de descentralização da saúde, dando ênfase a formas de enfrentar os desafios ainda não superados pela municipalização da saúde. 


\section{CAPÍTULO 1}

\section{MUNICIPALIZAÇÃO DA SAÚDE}

Segundo o Ministério da Saúde (BRASIL ${ }^{15}, 2.000$ ) dos 5.506 municípios brasileiros, 5.451 (99\%) estavam habilitados à gestão municipalizada da saúde, em 15/012/2000. Essa situação constitui, em tese, um êxito dos defensores da municipalização da saúde. Em suma, com a criação das condições juridico-legais, a quase totalidade dos municipios brasileiros está formalmente habilitada, de acordo com as normas vigentes, à gestão municipalizada da saúde.

Qual é o saldo desse processo?

Não é fácil responder a esta pergunta. A municipalização da saúde tem sido analisada em diversos estudos, a partir de diferentes enfoques. No campo da Reforma Sanitária é um assunto sobre o qual não existe consenso. Apesar de não existirem divergências a respeito da importância da descentralização na implantação do Sistema Único de Saúde (SUS), existem claras discordâncias quando se trata de analisar a forma pela qual o processo está sendo conduzido. Há os que acham que está ocorrendo com excessiva autonomia municipal e os que, pelo contrário, consideram que os municipios ainda não têm a desejável autonomia para assumir a gestão da saúde.

Os que são contrários à municipalização da saúde, da forma como está sendo implantada, consideram-na em essência "radical" (MENDES ${ }^{82}$, 1998), propondo redefinição dos papéis de estados, municípios e União no processo de descentralização do setor saúde. Criticam os segmentos do movimento municipalista que pretendem seja conferida autonomia excessiva 
aos governos municipais, considerando que estes segmentos procuram ressaltar apenas os aspectos positivos da municipalização da saúde; são contrários à descentralização que está ocorrendo no pais, polarizada, segundo eles, entre União e municípios, e acham que as atuais normas valorizam em excesso o papel dos últimos, em detrimento de instâncias estaduais e regionais de gestão (MENDES ${ }^{82} 1998$, p. 39).

Os que são partidários da municipalização com a maior autonomia possivel criticam, por sua vez, as normas federais que operacionalizam a descentralização, considerando-as dificultadoras do pleno exercicio da autonomia local, ao imporem parâmetros e políticas de "cima para baixo", sem a participação dos atores locais (BUENO e MEHRY'", 1998). Alguns muncipalistas, além disso, consideram que o financiamento federal para a gestão municipal da saúde tem sido insuficiente, sendo este um dos principais fatores da persistência das atuais dificuldades.

Os diferentes posicionamentos e as diferentes avaliaçōes quanto ao processo de municipalização da saúde em nosso pais mostram que, no campo dos aliados da. Reforma Sanitária brasileira, existem dúvidas e discordâncias sobre os acertos e desacertos na implementação da descentralização do setor saúde.

Essas dúvidas e discordâncias podem ser explicadas, pelo menos em parte, pelas dificuldades que o projeto da Reforma Sanitária brasileira tem encontrado para se viabilizar, especialmente a partir da década de 90 , num contexto político em que se tornou comum o descumprimento dos dispositivos constitucionais, passando a considerar-se a descentralização da saúde não como uma das estratégias de garantia de direitos conquistados mas de redução das responsabilidades do poder central. A contradição entre o projeto da Reforma, que amplia direitos, e as politicas recessivas, que os restringem, aumenta os espaços para os projetos de saúde voltados exclusivamente aos interesses do mercado. 
$\dot{E}$ nesse contexto, caracterizado por permanente tensão entre o projeto da Reforma Sanitária e o projeto neoliberal, articulado com o mercado e pautado pelas políticas de ajuste fiscal e de reforma do Estado, que será feita a análise da municipalização da saúde, neste capítulo. Procuramos realizá-la considerando os aspectos conceituais da municipalização da saúde, o histórico da descentralização segundo o projeto da Reforma Sanitária brasileira, e o contexto mais recente, do final da década de 90.

\subsection{Conceitos}

\section{DESCENTRALIZAÇÃO: CONCEITO E VALOR IDEOLÓGICO}

Centralização e descentralização são conceitos que têm sido utilizados com diferentes significados, na análise das politicas públicas. ROVERSI-MONACO ${ }^{103}$ (1986) considera a centrauzação e a descentralização política e administrativa do Estado moderno como situações idealizadas e, em conseqüência, nunca totalmente atingidas. Para descrever situaçōes nas quais existe predominância de uma ou outra forma de governo, deve-se considerar centralização aquela em que os "poderes das entidades locais e dos órgãos periféricos são reduzidos ao mínimo indispensável" e descentralização "quando os órgãos centrais do Estado possuem o mínimo de poder indispensável para desenvolver as próprias atividades" (p.330).

Tanto a centralização quanto a descentralização constituem-se elementos presentes na organização do Estado; não existem em estado puro. Seria utópico imaginar um Estado totalmente centralizado, assim como seria impossivel um processo total de descentralização, pois isso contrariaria a própria noção de Estado. Esses conceitos não podem ser tratados sem considerar o ambiente social e o momento histórico, pois não ocorrem de 
maneira idêntica em todos os lugares e todas as épocas (ROVERSIMONACO ${ }^{103}, 1986 ;$ STEIN $\left.^{116}, 1997\right)$.

A dificuldade de conceituar com precisão centralização e descentralização tem sido associada às diferentes interpretações que costumam atribuir-se aos seus significados. É comum associar centralização com governos autocráticos, pouco ou nada permeáveis à participação popular, e descentralização com governos democráticos, que preservam ou procuram ampliar as liberdades individuais. Essa associação nem sempre corresponde à realidade histórica e deve ser vista com ressalvas. Igualmente incorreto é associar descentralização, automaticamente, como uma estratégia situada no campo progressista da atuação política, e centralização como ligada ao campo conservador.

A descentralização tem sido utilizada como valor ideológico e como diretriz política das mais diversas formas e segundo distintas conveniências. Pode constituir-se e, de fato, vem-se constituindo na América Latina, como exemplificaremos adiante, tanto em uma estratégia política de implementação do neoliberalismo, situando-se, portanto, no campo conservador do espectro político, quanto em uma estratégia de democratização. Como a descentralização pode identificar-se com várias ideologias, devem-se considerar em sua análise as diferentes motivações com as quais se associa e o momento histórico e contexto politico com que está relacionada (TEIXEIRA ${ }^{121}$, 1990; FELICÍSSIMO ${ }^{43}$, 1992).

Apesar de a descentralização poder ser tratada pelos diferentes interessados da forma que lhes é mais conveniente e oportuno, não resta dúvida, no entanto, que a maioria dos autores, quando analisam esse tema, - fazem associando descentralização com o objetivo de democratizar o Estado e promover justiça social. Isso tem feito com que o tema descentralização constitua uma bandeira dos setores progressistas da sociedade, no campo da militância politicosocial. De acordo com esse 
entendimento, é a partir da descentralização do processo de decisão das políticas públicas que se ampliam os canais institucionais de participação e se incorporam novos sujeitos sociais aos centros de poder. A descentralização, de acordo com esta racionalidade, constitui uma forma de aproximar a sociedade do Estado, ao mesmo tempo em que amplia a responsabilidade dos cidadãos no processo decisório, desloca os eixos de poder, aproximando-os da população.

\section{DESCENTRALIZAÇÃO NA AMÉRICA LATINA: DUAS SIGNIFICAÇÕES DISTINTAS}

Quando se considera o processo histórico de descentralização das politicas sociais na Amérıca Latina, e em particular no Brasil, este tema tem duas dimensões de significação distintas: a política e a econômica. $\mathrm{Na}$ dimensão política, a descentralização pode ser considerada como um instrumento fundamental na estratégia de democratização do Estado. Por esse motivo ela compõe a agenda dos que lutam contra os estados autoritários. Na dimensão económica, a descentralização tem sido utilizada, especialmente a partir da década de 90 , como estratégia de redução do déficit público e estabilização da economia, visando contribuir com o ajuste fiscal do Estado (COHN ${ }^{33}$, 1998; TEIXEIRA ${ }^{121}$, 1990; FELICISSIMO ${ }^{43}$, 1992).

Essas duas dimensões de compreensão do significado de descentralização, política e econômica, constituem um dos aspectos centrais na análise das politicas sociais nos paises emergentes. Enquanto em uma das dimensões predomina a lógica de descentralização como uma proposta política de deslocamento dos eixos de poder para as instâncias locais, ampliando, como conseqüência, os mecanismos institucionais de democracia formal e promovendo a participação direta da sociedade, na outra predomina a lógica da racionalidade econômica, onde se descentraliza para cobrar maior racionalidade e eficiência na execução das politicas setoriais. 
Em situação de crise fiscal do Estado, hoje predominante na maioria dos países latino-americanos, esta segunda dimensão, a econômica, acaba tendo maior correspondência com a realidade do processo de descentralização. Considerando mais especificamente a descentralização das políticas sociais, é importante ressaltar que as propostas de redução dos gastos públicos, apresentadas por organismos financeiros internacionais, (Banco Mundial, por exemplo) acabam sendo mais bem sucedidas quando são aplicadas nos setores sociais, em virtude de serem setores mais frágeis no processo de negociação dos ajustes. Nesse caso, o resultado prático da descentralização, como afirma TEIXEIRA ${ }^{121}$ (1990, p.81), acaba sendo a privatização de setores sociais, porquanto a transferência e a delegação đ* responsabilidades pode sair da esfera pública, além de serem instituidas taxas de cobrança para utilização de serviços antes acessiveis sem ônus para os usuários.

Para a compreensão do significado da descentralização em situaçōes históricas concretas, é necessário compreender como essas duas dimensões, a política e a econômica, se articulam nas complexas sociedades modernas. De acordo com SANTOS (1995 apud $\mathrm{COHN}^{33}, 1998$ ). coexistem nessas sociedades, contraditoriamente, dois princípios: o da emancipação e o da regulação. Enquanto o primeiro aponta para a igualdade e a integração social, o segundo, produzido pelo próprio desenvolvimento capitalista, amplia a desigualdade e os fenômenos de exclusão social (p.147). É necessário considerar, em sintese, que os limites e possibilidades da descentralização não existem, a priori, fazendo parte dessa relação contraditória. O resultado do processo de descentralização não é necessariamente bom ou ruim; depende ele de cada ambiente social e político em particular, que configuram o contexto onde ocorrem as mudanças. 


\section{DESCENTRALIZAÇÃO E GLOBALIZAÇÃO}

Os efeitos da globalização, ou mundialização, como preferem alguns, têm trazido novos elementos de complexidade na análise do processo de centralização e descentralização nas sociedades modernas. CHESNAIS (1994 apud GUIMARÃES NETO e col. ${ }^{53}$ 1998, p.10) refere-se à atual situação mundial, em que as grandes corporações necessitam realizar operações diretas com as instâncias locais, dando a falsa impressão de descentralização. Na verdade, diz o autor, o poder das corporações globais é altamente centralizado e o que está de fato ocorrendo não é uma descentralização e sim uma reduçăo da regulação das instâncias nacionais ou regionais; ou seja, reduzem-se as intermediações na regulação e no exercício do poder, ocasionando uma centralização ainda maior. Esse poder passa a ser exercido cada vez menos pelos governos e mais pelas grandes corporações globais.

\section{DIFERENTES TIPOS DE DESCENTRALIZAÇÃO}

Diversos estudiosos têm procurado classificar e construir uma tipologia para a descentralização. Para sua classificação devem-se diferenciar as intra-governamentais, que operam de "dentro para dentro" do próprio governo e as inter-institucionais, que operam de "dentro para fora" do órgão governamental que descentraliza (FELICÍSSIMO ${ }^{43}$ 1992, p.10).

\section{(a) DESCENTRALIZAÇÕES INTRA-GOVERNAMENTAIS}

As descentralizaçōes intragovernamentais podem ser de dois tipos: desconcentração e descentralização funcional.

A desconcentração é uma delegação de responsabilidades aos níveis hierárquicos inferiores para a realização de determinados serviços, sem a delegação de poder decisório. Delega-se o poder de agir, mas não o de decidir (TEIXEIRA ${ }^{121} 1990$, p.83; MULLER NETO ${ }^{89} 1991$, p.55; MENDES ${ }^{82}$ 1998, p.30). A desconcentração é muito comum nas situações em que órgãos centrais de governo, tais como Ministérios e Secretarias Estaduais, criam entidades regionais a eles vinculados e transferem aos mesmos a 
execução de determinados serviços. Efetuam um rearranjo no processo de implementação das politicas e ações de governo, não delegando, no entanto, possibilidade de alteração no que já foi decidido pelas instâncias centrais.

A descentralização funcional, que também recebe denominações de descentralização autárquica ou descentralização institucional, constitui a transferência de responsabilidades no âmbito administrativo dentro da mesma estrutura de governo. Trata-se de criação de órgãos de administração indireta, tais como empresas públicas, sociedades de economia mista, fundações ou autarquias, que passam a assumir funções da competência dos órgãos da administraçăo direta. Assim como a desconcentração, também não é uma descentralização que transfere poder de um núcleo político para outro mais descentralizado. Preserva o poder central e, por esse motivo, como afirma TEIXEIRA ${ }^{121}$ (1990, p.84), é mais compativel, como analisaremos no capítulo 2, com os chamados estados unitários. De forma semelhante ao que ocorre com a desconcentração, na descentralização funcional o objetivo que se pretende atingir está ligado à redução da burocratização e rigidez nas açōes de governo. Uma diferenciase da outra forma apenas por aspectos juridico-administrativos (MULLER NETO ${ }^{89} 1999$, p.55; FELICÍSSIMO ${ }^{43}$ 1992, p.10).

(b) DESCENTRALIZAÇÕES INTER-INSTITUCIONAIS

No grupo das descentralizações interinstitucionais, o poder decisório é transferido de uma instituição governamental para outras entidades. As instituições que recebem as novas atribuições de poder podem ser outras instituições governamentais, de niveis hierárquicos inferiores, ou pertencer à sociedade civil. Nesse grupo estão a devolução e a delegação.

A devolução (JACOBI, 1993 apud MENDES ${ }^{82}$ 1998, p.30-31), que também é chamada de descentralização territorial, é uma transferência de poder entre diferentes niveis de governo, na qual os níveis superiores 
transferem responsabilidades politicas e administrativas para os inferiores. Transfere-se, em tese, o poder de agir e também o de decidir. Os níveis de governo que assumem as novas responsabilidades não só implementam o que foi decidido centralizadamente quanto podem formular novas políticas

A devolução estimula a ampliação da autonomia local, em especial do chamado poder local. É mais compativel com estados onde predomina o federalismo, como é o caso do Brasil. Embora os autores consultados não explicitem, suponho que seja mais apropriado considerar devolução como descentralização político-administrativa, já que este é o seu significado predominante

Na delegação, os órgãos de governo transferem poder de decisão a instituições ou entidades da sociedade civil. Isso tem ocorrido mais freqüentemente no Brasil com organizações não-governamentais (ONGS) ou outras entidades sem fins lucrativos. Constitui a delegação uma das estratégias de ampliação da privatização do atual governo, que se consubstancia no plano diretor de reforma do aparelho de Estado do Ministério da Administração e Reforma do Estado - MARE (BRASIL ${ }^{10}$, 1995).

\section{MUNICIPALIZAÇÃO}

Os diferentes aspectos que foram citados a respeito do conceito de descentralização permitem deduzir que, de acordo com a tipologia utilizada, a municipalização é uma devolução, podendo também ser chamada de descentralização territorial ou descentralização político-administrativa.

Pelo fato de envolver o nível local de governo, seu estudo envolve questões ligadas a poder local, municipalismo, federalismo e estados unitários, que serão analisados no capítulo 2.

Com respeito à municipalização da saúde no Brasil, CUNHA (1994 apud PAIM ${ }^{95}$, 1999) considera que está relacionada com a distribuição de 
poder. Esse autor assim se refere à municipalização: "Municipalizar a saúde significa o reconhecimento da responsabilidade politica do município com a saúde dos seus cidadãos. (O municipio) passa a assumir a formulação de políticas de âmbito local, o planejamento, a organização, a execução, a avaliação e o controle das ações e serviços de saúde na sua área de atuação. (...) A municipalização é parte de uma estratégia para a concretização dos principios constitucionais de universalidade, integralidade, eqüidade e controle social, através da devolução de poderes ao municipio, da descentralização das ações e serviços de saúde e da transformação da relação entre o poder público e a sociedade" (p.489).

Assim como esse autor, muitos outros também associam municipalização da saúde com deslocamento de poder. A análise do significado histórico da municipalização da saúde no Brasil mostra que existem diferentes motivaçōes e interesses envolvidos que conformam esse deslocamento de poder, como se verá a seguir.

\subsection{Histórico}

Alguns estudiosos da Reforma Sanitária brasileira atribuem à III Conferência Nacional de Saúde (CNS), de 1963, a primazia na tentativa de descentralização da saúde no país. Essa Conferência foi convocada para discutir quatro itens fundamentais: (1) a situação sanitária da população brasileira; (2) a distribuição e coordenação das atividades médico-sanitárias em âmbito federal, estadual e municipal; (3) a municipalização dos serviços de saúde e (4) a fixação de um Plano Nacional de Saúde (FADUL ${ }^{42}$ 1978, p.67). Pela primeira vez uma Conferência Nacional de Saúde assume a diretriz explícita de municipalizar a saúde.

Não existe consenso quanto ao real significado histórico dessa Conferência para o processo de descentralização da saúde no país. Autores como ELIAS $^{40}$ (1996, p.103-105) preferem considerá-la como simples 
tentativa de promover maior igualdade na extensão de cobertura dos serviços, sem ligação com as propostas de descentralização da saúde preconizadas pelo movimento sanitário.

Sem dúvida, nos interesses expressos pelos idealizadores dessa Conferência não se identifica na proposta de municipalização da saúde a intenção de ampliação de autonomia política e administrativa das instâncias locais, um dos pontos centrais da descentralização da saúde conforme preconizado pelo movimento sanitário. Essa Conferência, no entanto, tem o mérito de ter manifestado, pela primeira vez, a intenção de incluir na agenda sública a criação de uma rede municipal de serviços de saúde intenção esta abortada pela ruptura institucional ocorrida no ano seguinte

\section{DÉCADA DE 1970}

No período que se seguiu entre a realização dessa Conferência e a criação do Programa de Interiorização das Ações de Saúde e Saneamento (PIASS), em agosto de 1976, ocorreram no país alguns experimentos de atenção à saúde que tinham como objetivo a organização de serviços locais. De acordo com PAIM ${ }^{95}$ (1999, p.489-490), no final da década de 1960 e inicio dos anos 70, a expansão local dos serviços teve influência da proposta de Medicina Comunitária norte-americana. Essa proposta, que nos EUA era voltada à população pobre e negra, passou a ser apoiada no Brasil por fundações norte-americanas e era geralmente vinculada a algumas universidades e movimentos de igrejas.

A essas experiências localizadas e dirigidas à população carente, consideradas como "programas comunitários de saúde", seguiram-se alguns projetos-pilotos ligados a departamentos de medicina preventiva, social e comunitária de algumas universidades, direcionados às comunidades locais, ainda na década de 1970. Esses novos projetos consistiam em implantação de serviços básicos de saúde em áreas pobres de periferias urbanas ou 
rurais, procurando integrar as ações preventivas com as curativas. Apesar de contra-hegemônicas ao modelo médico vigente e coincidirem com a origem do movimento sanitário, a base político-ideológica da Reforma Sanitária brasileira, segundo $\operatorname{ESCOREL}^{41}$ (1998, p.23), tinha eventualmente o apoio dos governos latino-americanos "por serem soluções baratas para uma demanda crescente de atenção à saúde".

É arriscado, no entanto, simplificar a influência dos diversos movimentos teóricos e práticos, que, no campo da Saúde Coletiva, influenciaram no surgimento desses serviços locais. Referindo-se aos aspectos históricos da Saúde Coletiva e à emergência de um "projeto preventivista" para a América Latina nesse periodo, $\operatorname{NUNES}^{\mathbf{9 0}}(1994$, p.6) diz o seguinte: "Como tem sido abordado por estudiosos desse período, a emergência desses projetos reflete, de modo geral, o contexto socioeconômico e político-ideológico mais amplo, como também as sucessivas crises, presentes tanto no plano epistemológico, como no das práticas em saúde e da formação de recursos humanos". Afirma ainda este autor que os projetos preventivistas da época, que se traduziram em programas extramuros de faculdades de Medicina, expressos na chamada "medicina comunitária", tiveram vinculo mais forte a projetos pedagógicos do que a reforma das práticas médicas.

Algumas dessas experiências mais bem sucedidas, tais como as de Londrina-PR, Campinas-SP e, especialmente, de Montes Claros, no Norte de Minas Gerais, passaram a constituir referências para a expansão desse tipo de modelo (ESCOREL ${ }^{41}$ 1998, p.154). Estimuladas pelo movimento municipalista de saúde, que na época começava a se articular em encontros nacionais de secretários municipais de saúde, os representantes do movimento sanitário necessitavam de bases empíricas para um novo modelo de saúde (GOULART ${ }^{52}$, 1996; PAIM5 ${ }^{95}$ 1999). 
Com o surgimento do Programa de Interiorização das Ações de Saúde e Saneamento (PIASS), em 1976, o processo de descentralização da saúde passa a ter a participação do governo federal. Esse programa, concebido na Secretaria do Planejamento da Presidência da República, recebeu influência, em sua elaboração, de técnicos que partilhavam das idéias do incipiente movimento sanitário; tratava-se de um programa de medicina simplificada que tinha como principal finalidade expandir a rede de postos e centros de saúde para o atendimento das doenças mais comuns. Inicialmente, a expansão desse modelo ocorreu no Nordeste e, posteriormente, em todo o pais. A rede ambulatorial pública passou de 1.122 para 13.739 unidades em periodo de cerca de dez anos (MENDES ${ }^{* 0}, 1993$ p.28) e deu impulso a algumas mudanças estruturais no sistema de saúde. Entre estas destacam-se importantes modificações na composição de recursos humanos, com a criação da carreira de sanitarista e a incorporação ao sistema de grande número de "atendentes" de saúde pública. Passou a ocorrer também maior envolvimento das secretarias estaduais de saúde e das prefeituras com o sistema de saúde do país.

Esse período, especialmente até o final da década de 1970, coincidia com a plena vigência do Estado burocrático-autoritário, caracterizado por intensa centralização do poder, repressão política e arrocho salarial, como decorrência da crise do "milagre econômico", no final da década de 1960 e início da década de 1970. Alguns técnicos ligados ao movimento sanitário passaram a ocupar cargos de poder no aparelho de Estado, nos três escalões de governo, e passaram a exercer influência na elaboração das políticas de saúde. Documentos oficiais explicitavam a importância da descentralização da saúde e da participação comunitária.

O incipiente processo descentralizatório, em momento político de ausência de liberdades democráticas, não se caracterizava por deslocamentos nos eixos do poder, que continuava acentuadamente centralizado. Possibilitava, no entanto, que mais atores sociais aderissem ao 
movimento sanitário e se aglutinassem na crítica ao chamado modelo médico-assistencial privatista, caracterizado por uma série de distorçōes. Entre estas destacavam-se: (1) o excesso de atividades no âmbito da medicina curativa; (2) a exclusão na cobertura assistencial de amplos segmentos sociais não-cobertos pela assistência previdenciária; (3) a falta de controle público das ações desenvolvidas pelo setor privado médicohospitalar contratado, gerando distorçōes, fraudes, desperdícios e custos crescentes e (4) o fraco impacto do modelo vigente na melhoria dos indicadores de saúde, entre outros. Este modelo tinha o Estado como o grande financiador das ações desenvolvidas, o setor privado nacional como - maior prestador da assistência médico-hospitalar e o setor privado internacional como fornecedor de insumos e equipamentos. Essa realidade, induzida pelo Estado e resultante de sua intervenção, leva ao surgimento de um complexo industrial médico-hospitalar cujos interesses estimularam a manutenção e ampliação do modelo de saúde vigente.

O fortalecimento do movimento sanitário, além da ampliação da crítica a essa situação, possibilitou também a visualização da imagem-objetivo de um novo modelo de saúde, universal e igualitário, bastante inspirada na reforma sanitária italiana, e que passou a servir de referência para a reforma sanitária brasileira.

\section{DÉCADA DE 1980}

Com base na experiência do PIASS, surgiu, no início dos anos 80 , nova proposta de politica de saúde, o Programa Nacional de Serviços Básicos de Saúde, que ficou conhecido como PREV-SAÚDE. Essa proposta, influenciada também pela VII Conferência Nacional de Saúde, de 1980, apareceu em contexto de grave crise da Previdência Social, inflação galopante e recessão econômica, com mais de 40 milhões de brasileiros sem acesso aos serviços de saúde (MAGALDI ${ }^{65}$, 1995; CHIORO e col. ${ }^{29}$, 1997). O PREV-SAÚDE foi um ambicioso projeto conjunto do Ministério da 
Saúde (MS) e do Ministério da Previdência e Assistência Social (MPAS) que tinha como objetivo a "reorientação do sistema de saúde, mediante a integração programático-funcional entre os dois ministérios e as secretarias estaduais e municipais de saúde" (PAIM ${ }^{95}$ 1999, p.491). Além de reforçar a Atenção Primária à Saúde (APS), o PREV-SAÚDE previa a reorganização do sistema de saúde, com regionalização, hierarquização, participação da comunidade e atenção integral. Apesar de constituir-se em política classificada como racionalizadora, assim como foi o PIASS, o PREV-SAÚDE não saiu do papel. Esse programa contrariou muitos interesses e não foi implementado por resistências diversas dentro do próprio governo (burocracia do INAMPS), e fora dele (ABH - Associação Brasileira de Hospitais e ABRAMGE - Associação Brasileira de Medicina de Grupo).

Em 1982, a crise financeira da Previdência Social levou o governo a propor um conjunto de medidas racionalizadoras para enfrentar as despesas crescentes com assistência médico-hospitalar. Surgiu, então, o "Plano de Reorientação da Assistência no Âmbito da Previdência Social", por iniciativa do Conselho Consultivo da Administração da Saúde Previdenciária CONASP. Esse plano, que ficou conhecido como Plano do CONASP, desencadeou várias modificações no sistema de saúde vigente e acabou tendo importância significativa nas etapas subseqüentes do processo de descentralização da saúde. Incorporou propostas do PREV-SAÚDE e do movimento sanitário, entre as quais a regionalização dos serviços e a integração entre os diferentes escalões de governo na assistência à saúde. O objetivo central do plano do CONASP, no entanto, era a eliminação da ociosidade dos recursos públicos, para ampliar a produtividade e a eficiência do sistema de saúde.

Os convênios trilaterais, entre o Ministério da Saúde (MS), Ministério da Previdência Social (MPAS) e as Secretarias Estaduais de Saúde (SES), constituíram uma das iniciativas do plano do CONASP. Pela primeira vez a descentralização da saúde passou a fazer parte da política oficial, 
propiciando alguma transferência de poder para os governos estaduais. Os convênios trilaterais, mesmo que de forma tímida, delegavam poder de interferência na assistência médico-hospitalar do sistema previdenciário contratado, já que até então essa área era prerrogativa exclusiva do Ministério da Previdência e Assistência Social.

Apesar da importância que teve como fato simbólico para o processo de descentralização, não foi o projeto dos convênios trilaterais que caracterizou o plano do CONASP. Esse plano ficou marcado por suas medidas racionalizadoras nas áreas ambulatorial e hospitalar, entre as quais se destacaram: (1) a criação das AlHs - autorizações de internações hospitalares. Essa nova sistemática de controle de internações hospitalares passou a remunerá-las não mais por unidades de serviço, como no sistema anterior de GIHs (guias de internações hospitalares), mas por diagnósticos e procedimentos hospitalares; (2) o planejamento por parâmetros de demanda/oferta de serviços, a partir da Portaria MS n. ${ }^{\circ} 3046$, de 1982, que consolidou uma cultura de avaliação e controle baseada na tradição do então ainda poderoso INAMPS (Instituto Nacional de Assistência Médica da Previdência Social), contribuindo para reforçar o modelo médico-curativo hegemônico (MENDES ${ }^{80}, 1993$ ).

Com a proposta de abertura política do governo Geisel, no inicio da década de 1980, numa conjuntura de dificuldades econômicas e grande insatisfação da população com o governo, a oposição amplia suas bases de sustentação política. Cresce a mobilização da sociedade civil, que passa a reivindicar eleiçōes diretas para presidente da República (movimento das "Diretas Já"). Alguns governos estaduais e municipais são ocupados por oposicionistas, entre os quais muitos aliados do movimento sanitário. Aumenta o peso político de diversos atores sociais partidários da Reforma Sanitária. Técnicos da área da saúde ligados a este movimento, que já participavam da estrutura de poder do INAMPS e do Ministério da Saúde, passam a estar presentes também nas secretarias estaduais e municipais 
de saúde. Tudo isso contribui para fortalecer o processo de descentralização e municipalização da saúde.

Em 1984, através de portaria interministerial envolvendo o Ministério de Educação e Cultura (MEC), Ministério da Previdência e Assistência Social (MPAS) e Ministério da Saúde (MS), é criado o Programa das Ações Integradas de Saúde (AIS). As AIS representam um reforço à descentralização, ao propiciar a assinatura de convênios entre a União, estados e municípios, voltadas para o desenvolvimento de ações de saúde pública e de assistência médica. Instituem-se formas colegiadas de gestão, denominadas "comissões interinstitucionais de saúde" nas instâncias federal (CIPLAN), estadual (CIS), regional (CRIS), municipal (CIMS) e local (CLIS), que foram, posteriormente, substituidas pelos conselhos de saúde.

Muitas das administrações municipais que tinham tomado posse em 1982, assim como algumas administrações estaduais, entre as quais se destacaram as do Paraná e de São Paulo, aproveitaram o contexto das AIS para promover avanços no processo de descentralização da saúde. Multiplicam-se experiências municipais bem-sucedidas de implantação de politicas municipais de saúde, tais como as de Cachoeiras de Macacu-RJ, Cambé-PR, Juiz de Fora-MG, Bauru-SP, Rondonópolis-MT, Pelotas-RS, Uberlândia-MG, entre outras, que se transformaram em um considerável reforço para a municipalização da saúde (MULLER NETO 1991, p.60).

Esse período caracterizou-se também pela intermediação clientelista de políticos situacionistas da bancada federal na expansão dos convênios/AIS, em virtude do expressivo volume de recursos envolvidos, correspondente a cerca de $5 \%$ do orçamento global do INAMPS (MENDES ${ }^{80}$ 1993, p.38). Os estados e municípios, nesse periodo, eram remunerados pelo governo federal com base nos serviços prestados na área de atenção médica. Isso representava, por um lado, aporte adicional de recursos 
públicos federais aos municípios, mas por outro não alterava as condições de gestão, que continuavam centralizadas.

A articulação da Aliança Democrática e a vitória de Tancredo Neves e José Sarney para a presidência da República, em março de 1985, coincide com o fortalecimento do movimento municipalista, cuja articulação foi fortalecida em encontros estaduais e nacionais.

O advento da Nova República e o fim do periodo autoritário é acompanhado pela expansão ainda maior das AIS e pelo fortalecimento dos sistemas municipais e estaduais de saúde. É nesse contexto que ocorre, em 1986, a VIII Conferência Nacional de Saúde (VIII CNS). Esse evento, considerado unanimemente pelo movimento sanitário como um dos marcos da Reforma, reúne em Brasilia mais de 5.000 participantes, entre representantes da sociedade civil e de sindicatos, alguns prestadores de serviços, corporações profissionais e gestores de saúde, entre outros. É necessário registrar que, na Conferência, setores representantivos do setor privado - como ABRAMGE e FBH - tiveram tolhida sua participação, fato considerado posteriormente por segmentos do movimento sanitário como erro estratégico, uma das causas da atual falta de controle do subsistema privado de saúde. Na Conferência é consolidada a doutrina do Sistema Único de Saúde (SUS), um sistema de saúde universal, igualitário, participativo, descentralizado e integral (CONFERÉNCIA NACIONAL DE SAÚDE $\left.{ }^{34}, 1987\right)$.

Em 1987, por decreto presidencial, é implantado o Sistema Unificado e Descentralizado de Saúde (SUDS). Esse sistema foi concebido pelos técnicos do movimento sanitário como "estratégia ponte", preparatória para a implantação do SUS. Nesse período de transição, pretendeu-se incorporar ao contexto das AIS os princípios da Reforma Sanitária, reafirmados na VIII CNS: (1) universalização na atenção à saúde ("saúde: direito de todos e dever do Estado"); (2) integralidade da atenção; (3) regionalização e 
hierarquização; (4) descentralização do processo decisório; democratização das instâncias gestoras e (6) política integrada de recursos humanos (MENDES ${ }^{80}$ 1993, p.43).

Ficou, então, claramente explicitada a diretriz de descentralizar as responsabilidades administrativas e de democratizar a gestão, incorporando novos atores ao processo decisório. O SUDS desconcentrou recursos, delegando responsabilidades administrativas e transferindo serviços, assim como também descentralizou parcelas do processo decisório, possibilitando às secretarias estaduais de saúde interferência na formulação das políticas de saúde. Ficou também reduzido o pooer de instâncias burocráticas centralizadas, entre as quais O INAMPS sendo extintas suas superintendências estaduais. Além disso, conforme afirma PAIM"s (1999) "o SUDS possibilitou o desencadeamento de mars dois processos no sentido de descentralização das ações e serviços de saude: a municipalização e a distritalização" (p.492). No sentido colocado por esse autor, a municipalização refere-se à desconcentraçăo de serviços e descentralização da gestão aos municípios, e a distritalizaçåo ao "processo político organizativo de reorientação do sistema de saúde, com ênfase no nível local, capaz de facilitar a implantação de modelos assistenciais alternativos, como base para a construção do SUS" (PAIM, 1996 apud PAIMs 1999, p.495).

O período de vigência do SUDS representou, na opinião de alguns autores, "um processo radical de alteração nas regras do processo decisório vigente" (DRAIBE e col., 1990 apud MULLER NETO ${ }^{89}$ 1991, p.61). Para esses autores, constituem fato significativo as mudanças observadas na estrutura do INAMPS. Essa autarquia, vinculada ao MPAS e criada no final dos anos 70 para gerir a assistência médica previdenciária, com o advento do SUDS, deixou de ser responsável pela prestação de serviços, que é transferida a estados e municipios, para tornar-se controladora e cofinanciadora do sistema de saúde. Passa a ocorrer também a descentralização do planejamento, que reduz o paralelismo e a ineficiência, 
ampliando a resolubilidade, universalidade, regionalização, hierarquização e integralidade das ações de saúde.

Essa redução do poder da burocracia federal foi marcada por diversos momentos de turbulência político-institucional. Os que tinham seus interesses contrariados, em especial a corporação burocrática do INAMPS, que perdia poder com a descentralização, e o subsetor privado, que temia ser preterido na destinação de recursos públicos federais, passaram a articular-se politicamente para preservar seus interesses.

Somado a isso, travava-se simultaneamente luta politica tamtwom no campo ideológico, na qual participavam, por um lado os setores mais conservadores, entre os quais a Federação Brasileira de Hospitais (FBH) e a Associação Brasileira de Medicinas de Grupo (ABRAMGE), que temiam uma estatização radical com o processo de reforma, e, de outro, facços do movimento sanitário que defenderam essa alternativa tanto na VIII CNS quanto na Assembléia Nacional Constituinte. Essa polêmica historica (estatização versus privatização) revelou-se falsa ou inexistente, na opınião de vários estudiosos da reforma. O movimento sanitário, em sua maioria defendia não a estatização dos serviços do sistema público, mas a garantia de que prevalecesse o seu caráter público. De qualquer forma, a visibilidade que assumiu essa controvérsia e os "fantasmas" que ela gerou em parcelas dos segmentos conservadores contrários à reforma contribuíram para o acirramento de ânimos, interferindo nas articulações políticas e no estabelecimento da correlação de forças que influenciaram as mudanças das politicas de saúde, na época.

Os partidários da Reforma tinham como meta o desmonte da máquina do INAMPS. Segmentos do subsetor privado e da burocracia do INAMPS, articulavam-se contrariamente a esse desmonte $e$, conseqüentemente, à implantação do SUDS. No final de 1987, no Congresso Nacional, as articulações do "Centrão", nome pelo qual ficou conhecido o grupo político 
conservador que apoiava o governo procurando garantir os cinco anos de mandato para o presidente Sarney, uniram as facções políticas mais conservadoras, que procuraram barrar a sua implantação, com o argumento de que o SUDS, ao descentralizar recursos, favoreceria politicamente os governos estaduais de oposição.

Essas articulações, apesar de não conseguirem interromper o processo de descentralização, dificultaram seu avanço. Além de campanhas de desqualificação dos governos estaduaıs e municipais promovidas pelas facções contrárias à descentralização, que eram acusados de incompetentes $e$ ineficientes no uso do dinheiro publico esses governos também foram penalizados com a redução acentuada do repasse de recursos federais (MULLER NETO ${ }^{89}, 1991$ ).

Apesar dessas dificuldades, o SUDS cumpriu o seu papel. Contribuíram para que não houvesse retrocesso algumas forças politicas, entre as quais governadores e prefeitos de oposição, técnicos e dirigentes de saúde, articulados em fóruns nacionais. Destacaram-se, nesses fóruns, os encontros nacionais de secretários municipais de saúde, em especial os de Olinda-PE, em 1988, Porto Alegre-RS, em 1989, e Fortaleza-CE, em 1990. Em Olinda-PE os secretários municipais de saúde criaram o Conselho Nacional dos Secretários Municipais de Saúde (CONASEMS). A consolidação desse ator social, que já se esboçava desde os primeiros anos da década de 1980, aumentou a pressão para a descentralização da saúde no pais (GOULART $\left.{ }^{52}, 1996\right)$.

Durante o V Encontro Nacional de Secretários Municipais de Saúde, realizado em Olinda-PE, de 11 a 14 de abril de 1988, além de ter sido criado o CONASEMS, foi publicada a Carta de Olinda, em que se manifestou apoio à "continuidade na implantação do SUDS", e a "preocupação com os retrocessos (...) a partir de uma composição das forças conservadoras". No VI Encontro, realizado em Porto Alegre-RS, de 04 a 07 de junho de 1989, e 
no VII Encontro, realizado em Fortaleza-CE, de 09 a 13 de dezembro de 1990, manifestou-se a preocupação de garantir o avanço da descentralização e, especialmente, de ampliar a autonomia de gestão municipal, a partir do "repasse automático de recursos entre as esferas de governo" (GOULART ${ }^{52}$ 1996, p.47-50).

Além do movimento municipalista e da atuaçāo dos políticos de oposição, também alguns movimentos sindicais, populares e instituições acadêmicas tiveram papel importante nessa fase da implantação do SUS. Merece destaque o Centro Brasileiro de Estudos da Saúde (CEBES) que, além de sua atuação no campo da militância, representou, segundo alguns autores, entre os quais TEIXEIRA ${ }^{122}(1997$ p 25), a própria institucionalização do movimento sanitário. Esse papel do CEBES é ressaltado por essa autora, ao afirmar que: “ (...) a institucionalização do movimento sanitário através da criação do CEBES, alcançando assim constituir-se um verdadeiro partido sanitário, foi capaz de organizar as diferentes visōes criticas do sistema de saúde, definindo um projeto comum e estratégias e táticas de ação coletiva" (p.26). Deve-se dar destaque especial à participação da ABRASCO, por suas expressivas contribuições no campo teórico.

A delegação de responsabilidades aos estados, no entanto, não impedia os governos estaduais de se relacionarem de forma clientelista com os municípios. Nada impedia, também, os governos estaduais de retraírem a destinação de recursos dos estados para a saúde, ao receberem os recursos federais transferidos por força dos convênios das AIS e do SUDS. Diversos estados mantiveram práticas centralizadoras e clientelistas no seu relacionamento com os municipios. Além disso, nos anos de 1987, 1988 e 1989, os gastos estaduais em saúde cairam drasticamente, chegando a ter crescimento negativo em 1988, ou seja, a soma dos gastos estaduais foi inferior ao total dos repasses federais, pois parte destes foram transferidos para outros setores do governo. Nesse ano, para um repasse federal aos 
governos estaduais de quatro bilhões, seiscentos e noventa e dois milhões de dólares, os gastos estaduais foram de quatro bilhões, vinte e três milhões e quinhentos mil dólares. Ou seja, houve uma diferença para menos de mais de seiscentos milhões de dólares dos recursos federais repassados. Os estados, em seu conjunto, além de não gastarem um único centavo dos seus recursos, utilizaram-se de seiscentos milhões de dólares da saúde para outros fins (VIANNA e col.126 1994, p.18). Apesar disso, porém, alguns estados, tiveram a preocupação efetiva de colocar em prática ações de apoio ao processo de descentralização e, em especial, de desmonte da estrutura burocrática federal, que teimava em resistir. JUNQUEIRA e col. * (1997) referem-se à implantação do SUDS no Estado de São Paulo, assinalando as diferenças observadas em relação a outros estados do país quanto ao processo de absorção do INAMPS. Ao assumir concretamente as decisões que cabiam à Superintendência Regional do INAMPS, em São Paulo, a Secretaria Estadual de Saúde assumiu mais rapidamente a gestão dos equipamentos e da rede própria federal, assim como parte do controle da compra de serviços junto ao setor privado, anteriormente toda centralizada.

Essa "estadualização da saúde", no entanto, independentemente de ter ocorrido nos diversos estados com maior ou menor rapidez ou com maior ou menor absorção das funções federais, foi nitidamente incompleta. Ou seja, a autonomia que os estados passaram a ter na gestão da assistência médico-hospitalar, especialmente junto ao setor privado, mesmo tendo representado um avanço para a época, era ainda bastante limitada. Os limites e os critérios para os gastos eram estabelecidos pelo governo federal. Até aquele período o processo de descentralização da saúde significou, no máximo, uma desconcentração de serviços do governo federal para os governos estaduais e municipais, sendo que, para estes últimos, ainda muito timidamente. 
Segundo PAIM $^{95}$ (1999, p.493), ocorreu no período de 1985 a 1988 o desencadeamento da Reforma Sanitária brasileira. Esse autor considera que o setor saúde, nesse período, avançou em sete pontos: (1) contenção das políticas privatizantes do INAMPS; (2) transferência de recursos federais previdenciários para estados e municipios; (3) prioridade para o fortalecimento dos serviços públicos; (4) estímulo à integração das ações e serviços de saúde; (5) apoio à descentralização gerencial; (6) incorporação do planejamento à prática institucional e (7) abertura de canais para a participação popular.

Com a promulgação do SUS pela Constituição de 1988, as forças políticas favoráveis à Reforma Sanitária sairam vitoriosas, já que o texto constitucional preservou as doutrinas e os principios aprovados na VIII CNS. O debate entre os favoráveis e contrários à implantação do SUS passa a ocorrer em outra arena política, o Congresso Nacional, onde iria dar-se a regulamentação das medidas constitucionais por intermédio das Leis Orgânicas da Saúde N. ${ }^{\circ} 8.080$ e N ${ }^{\circ} 8.142$.

DÉCADA DE 1990

No final dos anos de 1980 e no início da década de 1990 ocorre o avanço das propostas neoliberais e a redução do papel redistributivo do Estado. Esse contexto político e econômico influenciou de forma decisiva na implantação do SUS. Enquanto no Congresso Nacional e em outras arenas político-institucionais a agenda do setor saúde era ocupada pela regulamentação dos dispositivos constitucionais e pelas propostas de operacionalização das políticas aprovadas, o Estado brasileiro enfrentava intensa crise política e fiscal, que era o prenúncio do fracasso de sua estratégia desenvolvimentista (FIORI, 1991 apud MENDES ${ }^{80} 1993$, p. 49).

O avanço do neoliberalismo no continente latino-americano, que teve início na década de 1980, mas que atingiu seu auge no final da mesma e 
início dos anos 90, e que teve no Brasil um dos últimos paises do continente a se alinhar a essa proposta (SINGER ${ }^{110}$ 1998, p.108), somou-se ao retrocesso político representado pelo governo Collor. Esse governo assumiu o poder no início de 1990 e adotou, seguindo o receituário neoliberal, políticas econômicas racionalizadoras, que atingiam diretamente a viabilização e a expansão das políticas sociais compensatórias. Além disso, por causa do seu caráter conservador, o governo Collor impôs dificuldades para a descentralização e democratização da saúde, ao vetar pontos importantes da Lei 8.080, de 19 de setembro de 1990, que previam transferência direta e automática de recursos federais aos fundos estaduais e municipais de saúde e a participação deliberatıva da população no SUS, através de Conferências e Conselhos de Saúde.

A supressão de pontos vitais da formulação do SUS deu origem a grande mobilização e reação de setores da sociedade civil, exigindo o cumprimento dos pontos acordados na discussão do texto da lei. No VII Encontro Nacional de Secretários Municipais de Saüde (VII Encontro do CONASEMS), referido anteriormente, realizado em Fortaleza-CE de 9 a 13 de dezembro de 1990, o Ministro da Saúde, Alceni Guerra, reconheceu que os vetos foram decorrentes das pressões da área econômica do governo. No último dia do encontro foi enviado pelo ministro o texto de nova lei aprovada pelo Congresso, Lei 8.142, que dispõe sobre a participação da população e a transferência de recursos aos estados e municipios, sancionada pelo presidente em 28 de dezembro de 1990 (GOULART ${ }^{s 2}$ 1996, p.50). Essa vitória do movimento sanitário deveu-se não só ao CONASEMS, mas também a mais de duas centenas de entidades da sociedade civil, que se articularam em um fórum reivindicatório e político que ficou conhecido como Plenária Nacional pela Saúde na Constituinte.

À Constituição de 1988 e às Lei Orgânicas da Saúde, 8.080 e 8.142, se somam as Constituições Estaduais e as Leis Orgânicas Municipais, aprovadas em 1990, ficando constituido, dessa forma, o arcabouço juridico- 
legal do SUS. Essa vitória do movimento sanitário, que resultou em consagração jurídico-legal dos princípios da reforma sanitária nos três níveis de governo, teve apoio significativo do Instituto Brasileiro de Administração Municipal (IBAM), da Associação Brasileira de Pós-Graduação em Saúde Coletiva (ABRASCO) e do Centro Brasileiro de Estudos da Saúde (CEBES) (MULLER NETO ${ }^{89} 1991$, p.31)

Paralelamente a esse avanço, que institui o que alguns autores chamam de "SUS legal", coexistiam e se ampliavam as dificuldades para a sua efetiva implantação. A expansão da universalização dos direitos foi acompanhada de racionamento na oferta e de progressiva queda na qualidade dos serviços Torna-se visivel a tensão entre a dupla significação que tinha o processo de descentralização da saúde nesse periodo, a politica e a econômica, já referidas neste capitulo. A descentralização como estratégia politica de democratização avançou com a aprovação dos preceitos juridico-legais necessários. Nessa dimensão, a politica, consubstanciada na luta político-institucional, a vitória foi do movimento sanitário. O contexto de crise econômica e de implementação de politicas neoliberais, no entanto, também transformaram a descentralização em estratégia que passa a contribuir com o racionamento na oferta dos serviços sociais. Nessa segunda dimensão, a econômica, a descentralização favorece a manutenção dos mecanismos de exclusão social, ao propiciar a pulverização das demandas sociais, ao induzir à organização de um sistema assistencial de saúde com deficiências, voltado para pobres, e ao favorecer a expansão do mercado de planos e seguros de saúde.

O direito à saúde não foi acompanhado da confirmação desse direito, isto é, não se transformou em realidade. A "crise do Estado" é acompanhada de desativação progressiva de equipamentos federais e estaduais na área da saúde, em virtude da não-reposição de servidores e sucateamento desses serviços. A deterioração real dos valores pagos aos serviços privados contratados pelo SUS reduz acentuadamente a oferta desses 
serviços. Eles são selecionados em obediência à lógica de mercado, ampliando os espaços de demanda não atendida e a iniquidade e as injustiças do sistema de saúde. Essa situação favorece o crescimento de um subsistema privado de atenção médico-hospitalar supletiva, que passa a ser procurado pelas camadas médias que querem fugir do subsistema público.

O subsistema público passa a ser caracterizado mais nitidamente como o "SUS para pobre" (PAIM ${ }^{9 \leqslant} 1999$, p.494) e incorpora os segmentos mais carentes. Passa a oferecer assistência médica simplificada, reduzindo o acesso aos procedimentos mais complexos pela redução na sua oferta

O subsistema privado agrega segmentos sociais das camadas médıas e do operariado mais qualificado e se utiliza da falta de regulação pública para selecionar doenças e clientela, transferindo ao subsistema público usuárıs que não the interessa atender. O subsidio público e a baixa regulaçăo do Estado contribuiram para o rápido crescimento desse subsistema

Esse fenômeno, que passa a ser conhecido como "universalização excludente", incorpora os segmentos mais carentes, "expulsando" as camadas mais privilegiadas para o subsistema privado (FAVARET FILHO E OLIVEIRA, 1989 apud MENDES $^{\text {su }}$ 1993, p.53). Trata-se de clara manifestação da racionalidade econômica no enfrentamento dos excluidos da saúde, ao inclui-los não em uma condição de cidadania plena, igualdade na atenção, mas incorporando-os num sistema de saúde em situação de crescente racionamento e, simultaneamente, ao possibilitar a transferência daqueles que poderiam opor-se ao racionamento, pela via do mercado, para o subsistema privado

PAIM (1995 apud PAIM ${ }^{œ 4}$, 1999) passa a identificar quatro tipos diferentes de SUS, nesse periodo. Além do "SUS para pobre", da medicina 
simplificada, e do "SUS legal", presente nas leis, referidos anteriormente, tornam-se mais visiveis o "SUS real" e o "SUS democrático".

O SUS real é caracterizado pela situação de privilegiamento, falta de controle, "cobranças por fora" e iniqüidades do sistema de saúde.

O "SUS democrático" é o proposto pela Reforma Sanitária e ainda não-viabilizado. Para o movimento sanitário, portanto, o verdadeiro SUS, democrático, constitui uma imagem-objetivo. Os militantes da Reforma têm a percepção de que a construção do SUS, do SUS democrático, deve ser perseguida em diversos campos e a partir de diferentes estratégias

Entre as estratégias dos primeiros anos da década de 1990 que tiveram a participação ativa do movimento sanitário, duas se destacaram: A IX Conferência Nacional de Saúde (IX CNS) e a elaboração do documento intitulado "Municipalização das ações e serviços de saúde: a ousadıa de cumprir e fazer cumprir a lei".

A IX CNS, realizada em agosto de 1992, tem como tema central: "Saúde: a municipalização é o caminho". Com atraso de dois anos, em meio à crise do governo Collor, essa Conferência somente se realizou por causa da pressão de setores do movimento sanitário, com apoio do Ministério de Saúde, mas com discordância de outras áreas do governo. Concomitante a um tumultuado momento político, praticamente às vésperas do impeachment do presidente da República, que ocorreu no final daquele ano, a IX CNS constituiu um significativo ato político em favor do cumprimento das leis. Essa Conferência posicionou-se contrariamente a qualquer tipo de retrocesso na implantação do SUS. Tendo sido precedida de ampla mobilização social, sobretudo em conferências estaduais e municipais, essa Conferência, além de propugnar pelo cumprimento da Constituição e das Leis Orgânicas, reforçou a proposta descentralizante da Reforma. 
Com a queda do governo Collor, no final de 1992, técnicos comprometidos com o movimento de municipalização assumiram posições de destaque no Ministério da Saúde. Visando avançar no processo de descentralização, o Grupo Especial para a Descentralização do Ministério da Saúde (GED/MS) elaborou o documento "Descentralização do SUS: prioridade do Ministério da Saúde", em cujo conteúdo está presente o texto intitulado "Municipalização das ações e serviços de saúde: a ousadia de cumprir e fazer cumprir a ler" (BRASIL ${ }^{8}$, 1993). Esse documento reafirma a necessidade de descentralizar os recursos e a gestão da saúde para os estados e os municipios, cumprindo a legislaçăo do SUS, tendo sido seguido pela publicação, pelo Ministério da Saúde, em maı de 1993, da Norma Operacional Básica do Sistema Único de Savde 01/93 (NOB SUS/93) (BRASIL ${ }^{9}$, 1993). A NOB SUS/93 determina alteração significativa nos mecanismos de transferência de recursos federaıs aos municípios.

Enquanto as normas até então vigentes transferiam recursos federais aos outros níveis de governo com base na produção de serviços, considerando as secretarias estaduais e municipaıs como meros prestadores públicos de serviços ambulatoriais e hospitalares, a NOB SUS/93, em uma das formas de habilitação previstas, denominada semiplena, inaugura nova relação do governo federal com os outros niveis de governo, ao possibilitar transferência de recursos sem exigir dependência direta com a produção. Essa norma institucionaliza instâncias permanentes de negociação entre os niveis de governo, denominadas Comissões Intergestores Tripartite (CIT) União, estados municipios - e Comissões Intergestores Bipartite (CIB) estados e municipios - e cria três formas de gestão municipalizada da saúde: incipiente, parcial e semiplena.

Essas formas implicam responsabilidades, prerrogativas e direitos crescentes para os municípios, de modo que, na mais avançada, a semiplena, o município passa a ter direito ao repasse de recursos federais a partir de tetos mensais globais que não dependem do volume da produção 
de serviços. Essa nova forma de repasse amplia a autonomia dos municípios que podem alterar a programação dos serviços contratados e promover mudança nos modelos de saúde vigentes.

Com a transferência de recursos federais para os estados e municípios, isto é, do Fundo Nacional de Saúde (FNS) para os Fundos Estaduais de Saúde (FES) e Fundos Municipais de Saúde (FMS), como preconizado pela gestão semiplena da NOB SUS/93, tem inicio a etapa mais recente da descentralização da saúde. Essas mudanças constituem, em itse, o início da implementação das propostas do movimento sanitário. f ‘ ‘uelece-se a transferência automática e imediata de recursos aos muncipios, com a possibilidade de maior controle social, ja que os Conselhos de Saúde, nacional, estaduais e municipais, passam a ter a incumbência legal de fiscalizar os respectivos fundos de saúde.

A gestão semiplena passa a ser considerada por amplos segmentos do) movimento sanitário, entre os quais os militantes do movimento munıcipalista, como a forma de gestão mais adequada. Nessa forma, segundo esses segmentos, existe maior autonomia de gestão administrativa e financeira, e a possibilidade concreta de efetivo deslocamento de poder das instâncias centrais para o chamado poder local.

A partir de 1994, diversos municípios brasileiros habilitam-se à gestão semiplena. No final de 1994, eram 24 os municipios habilitados e, em meados do ano seguinte, 43 , abrangendo $7,4 \%$ da população do país. No final de 1997, mais de uma centena de municipios estavam habilitados à gestão semiplena. Esses municipios, distribuidos pelas mais diferentes regiões do país, abrigavam aproximadamente $12 \%$ da população e movimentavam cerca de $20 \%$ dos recursos federais transferidos do Fundo Nacional de Saúde para os fundos municipais (ALMEIDA' 1998, p.9). 
Em novembro de 1996, instituiu-se a NOB/SUS/96 (Norma Operacional Básica do Sistema Único de Saúde 01/96), por intermédio da Portaria n. ${ }^{\circ} 2203$. (BRASIL", 1996), que prevê duas formas de gestão: plena da atenção básica e plena do sistema de saúde, as quais substituem as formas anteriores. As responsabilidades, requisitos e prerrogativas dessas condições de gestão são, resumidamente, as seguintes:

- Gestáo plena da atenção básica, cujas responsabilidades são: elaborar a programação municipal dos serviços básicos; gerenciar as unidades amoulatoriais próprias; prestar ou acompanhar e controlar os serviços relacionados à atenção básica, e executar as ações básicas de vigiláncia sanıtana e epidemiológica. Os requisitos são: comprovação do funcionamento do Conselho Municipal de Saúde e da operação do Fundo Municipal de Saúde; ter Plano Municipal de Saúde; assumir o compromisso de participar da programação pactuada e integrada (PPI), e comprovar capacidade técnica e administrativa para desenvolver as açóes de sua responsabilidade. As prerrogativas são as de obter a transferéncia de recursos federais e ter as unidades básicas de saúde de seu território, estatais ou privadas, subordinadas à gestão municipal.

- Gestão plena do sistema municipal, cujas responsabilidade são: elaborar a programação municipal de serviços básicos, especializados e hospitalares; gerenciar as unidades ambulatoriais e hospitalares próprias; garantir a prestação de serviços em seu território, inclusive aos nãoresidentes, e a execução dos serviços aos seus municipes nos outros municipios, conforme a PPI (programação pactuada e integrada); exercer o controle público dos serviços ambulatoriais e hospitalares, e executar as ações em geral nas áreas de vigilância sanitária e epidemiológica. Os requisitos são: comprovação de funcionamento do conselho municipal de saúde (CMS) e da operação do fundo municipal de saúde (FMS); assumir o compromisso de participar da PPI; comprovar capacidade técnica e admınistrativa para desenvolver as ações de sua responsabilidade. As 
prerrogativas são as de obter transferências de recursos federais e ter o conjunto das unidades ambulatoriais especializadas e hospitalares de seu território, inclusive as privadas contratadas pelo SUS, subordinadas à gestão municipal.

A NOB SUS/96 amplia a municipalização da saúde. A norma estabelece como sua "finalidade primordial consolidar o pleno exercício, por parte do poder público municipal e do Distrito Federal, da função de gestor da atenção à saúde de seus municipes". O municipio é considerado o "responsável imediato pelo atendimento das necessidades e demandas de saúde do seu povo e das exigências de intervenções saneadoras em seu território" (BRASIL"1996, p.6).

Embora também normatize no seu teor mudanças nas gestões estaduais de saúde, instituindo as formas avançada e plena do sistema estadual e proponha um reordenamento do papel das três esferas de governo, a NOB SUS/96 é nitidamente municipalista. Utiliza-se da experiência acumulada com as gestões semiplenas e procura incentivar as transferências direta e automática de recursos federais para os fundos municipais de saúde, ampliando a responsabilidade de gestão dos governos locais.

Em 1998, inicia-se a habilitação dos municípios às gestões plena da atenção básica e plena do sistema de saúde, entrando em vigor, de fato, a NOB SUS/96. Esse processo expande-se rapidamente e, como está citado no início deste capítulo, 5.451 dos 5.506 municípios brasileiros já se encontravam habilitados no dia 31 de dezembro de 2000. Destes, 4.928 municipios estavam na gestão plena da atenção básica e 523 na gestão plena do sistema de saúde

Alguns autores têm publicado avaliações a respeito do processo de municipalização dos serviços de saúde no Brasil. Voltando um pouco no 
tempo, em artigo publicado em 1990, e portanto alguns anos antes da implantação das formas mais recentes de gestão, semiplena e plena, CAMPOS $^{20}$ (1990) fez uma série de consideraçōes sobre o processo de municipalização, das quais destacamos algumas: (1) a corrente municipalista tem considerado a questão da municipalização da saúde de forma ufanista e acritica, apresentando o municipalismo como uma panacéia que poderá resolver os problemas sociais do Brasil; (2) o desafio na análise do processo é esclarecer os vinculos entre o local e o nacional, já que muitos dos desafios do local dependem do nacional; (3) a descentralização existente (até entāo) não transfere recursos de forma automática e não se descentraliza poder sem descentralizar recursos e a descentralização só avança se ocorrer unificação do sistema.

Alguns anos depois, TEIXEIRA ${ }^{123}$ (1997), em pesquisa que abrangeu 1.422 municipios brasileiros, analisou a gestão municipal da saúde, tendo como principal preocupação o potencial de inovação possibilitado pela municipalização. Como o estudo se referiu ao periodo de setembro de 1996 a abril de 1997, foram pesquisados municipios em gestōes incipiente e parcial, além de alguns poucos que já estavam na semiplena. $A$ análise foi efetuada em três dimensões, denominadas social, gerencial e assistencial. A dimensão social, que incluía prestação de contas à comunidade e controle social, por exemplo, foi a que mais avançou, de acordo com os resultados da pesquisa. As dimensões gerencial e assistencial, que englobariam eficiência/eficácia e capacidade de inovação nas ações institucionais, respectivamente, em contrapartida tiveram avanços mais discretos, segundo esse trabalho.

No estudo de Teixeira, acima citado, evidencia-se a associação positiva existente entre a municipalização da saúde e a democratização. $A$ participação da população, especialmente no controle social, em sua dimensão de accountability (que será analisado conceitualmente no capitulo 2) apresentou crescimento. Por outro lado, as inovações nas formas de 
gestão que trazem mais eficiência, eficácia, criatividade e melhoria na qualidade, entre outras, tiveram relação com as características pessoais e profissionais dos secretários. Segundo os dados dessa pesquisa os secretários mais inovadores são mais participativos, militantes nas questões de saúde e, em especial, da reforma sanitária. Enfatiza-se a importância da liderança local no aperfeiçoamento da gestão.

Em 1988, por iniciativa do Ministério da Saúde, realizou-se uma pesquisa em 12 municípios que já estavam há mais de dois anos na gestão semiplena, procurando-se avaliar o processo de descentralızação e o seu ımpacto no sistema de saúde, tendo-se chegado às seguintes conclusões: (1) a gestão semi-plena faz avançar a descentralização no interior do sistema de saúde; (2) houve aumento na oferta de açōes e serviços de saúde; (3) imprimiu-se maior dinâmica na participação da comunidade; (4) o papel do gestor estadual (secretarias estaduais de saúde) ficou fragilizado nessa nova situação de gestão municipal, e (5) evidenciou-se que o gestor federal tem grande influência no direcionamento das politicas de saúde, por causa de seu poder de disponibilização de recursos (BRASIL ${ }^{16}, 2.000$ ).

$\operatorname{MENDES}^{82}$ (1998) considera que a NOB SUS/93 e a NOB SUS/96 inauguraram uma forma diferente de descentralização da saúde, criando relação direta entre o Ministério da Saúde e os municipios, sem a participação dos governos estaduais. Enquanto no periodo das AIS e do SUDS a descentralização tinha a participação dos secretarias estaduais de saúde, a partir de 1993 esses órgãos de governo ficaram esvaziados. O autor acima citado discorda da forma pela qual vem sendo conduzida a municipalização da saúde, como já foi mencionado no inicio deste capítulo. Destaca, apesar disso, alguns aspectos positivos: consolidação do mando único municipal; ampliação da capacidade de regulação dos prestadores de serviço por parte da secretaria municipal de saúde; ampliação do controle público dos serviços pelos conselhos de saúde; aumento da produtividade, e incorporação de segmentos populacionais desassistidos, entre outros. Entre 
os negativos, assinala os seguintes aspectos: reforço ao modelo flexneriano de atenção médica em detrimento das açōes de saúde pública; ineficiência na aplicação de recursos por perda de escala e pulverização de recursos públicos, e aumento da iniqüidade. Além desses aspectos negativos, denominados pelo autor de debilidades da descentralização, ele critica a ideologização do slogan "municipalização é o caminho", considerado equivocadamente indiscutível, segundo ele, por segmentos do movimento sanitário.

Fazendo uma análise da NOB SUS/96, BUENO e MERHY'19 (1998), discordam de alguns de seus aspectos Para esses autores, a gestão semiplena, instituida pelo NOB SUS/93 trouxe para a reorganização do sistema de saúde, avanços significativos que, no entanto, ficaram restritos a apenas $15,57 \%$ da população, porcentual correspondente aos habitantes de municipios nesta forma de gestão. Com a nova norma, a NOB SUS/96 afirmavam esses autores em 1997 - iria aumentar o número de municípios com repasse de recursos fundo a fundo, o que constitui aspecto positivo. Consideravam, porém, que os mecanismos de incentivos propostos para o financiamento das ações de saúde se dariam de forma verticalizada, ferindo o princípio de autonomia do gestor local. Entre esses mecanismos, sobressaiam os incentivos financeiros do Programa de Saúde da Familia (PSF) e do Programa de Agentes Comunitários de Saúde (PACS). A norma restringia a liberdade dos gestores locais, ao induzir os municipios a aderir a esses programas como estratégia de alteração do modelo assistencial e, em situações particulares, dizem os autores, as estratégias mais adequadas poderiam ser outras.

NOAS-SUS 01/2001

Em 26 de janeiro de 2001 foi publicada a NOAS-SUS 01/2001 (Norma Operacional da Assistência à Saúde 01/2001) por intermédio da portaria n. ${ }^{\circ}$ 95 do Ministério da Saúde (BRASIL ${ }^{18}$ 2001). Tendo como objetivos "amplia 
(r) as responsabilidades dos municipios na Atenção Básica" e definir o processo de regionalização da saúde essa norma amplia as responsabilidades das Secretarias Estaduais de Saúde na gestão do SUS. Propõe a organização de sistemas funcionais de saúde, compreendendo um ou um conjunto de municípios, como base do processo de regionalização, e delega às SES o papel de coordenadoras das mudanças.

Entre as principais modificações propostas pela NOAS-SUS 01/2001 destacam-se

(1) Elaboraçāo de um Plano Diretor de Regionalização (PDR), pelas Secretarias Estaduais de Saúde, que procure garantir acesso aos cidadãos, o mais próximo possivel da residência, de um conjunto mínimo de ações e serviços e, estabelece compromisso entre gestores para o atendimento de referência intermunicipais, procurando garantir também, dessa forma, o acesso aos outros niveis de atenção, mais complexos.

Para a organização da assistência no âmbito estadual, visando a implementação do processo de regionalização, o PDR utiliza os seguintes conceitos-chave:

(a) Regiões e microrregiôes de saúde: constituem bases territoriais de planejamento regionalizado que podem compreender um ou mais módulos assistenciais;

(b) Módulos assistenciais: correspondem a um conjunto de municípios ou, em alguns casos, a um único município - com resolubilidade para um elenco mais simples de serviços de média complexidade. O municipio-sede do módulo assistencial deve estar apto para oferecer esse elenco de serviços para si e para os outros municípios do módulo e estar habilitado na Gestão Plena do Sistema Municipal de Saúde;

(c) Municipio-pólo: é o que desempenha papel de referência para outros municipios em qualquer nivel de atenção. 
(2) Instituição da Gestão Plena da Atenção Básica Ampliada (GPABA). Para habilitar-se nesta forma de gestão os municipios em Gestão Plena da Atenção Básica (conforme preconizado pela NOB SUS 01/96) deverão responsabilizar-se pelos serviços básicos incluindo, obrigatoriamente, $\mathrm{O}$ controle de Tuberculose, Hanseniase, Hipertensão Arterial, Diabetes e desenvolver programas de atenção à saúde da criança, da mulher e bucal para os seus municipes.

Para a operacionalizaçāo da regionalização, a NOAS propõe utilização de instrumentos como PPI (Programação Pactuada e Integrada), termos de garantia de acesso firmado entre gestores para organizar as referências intermunicipais, definição de prioridades de intervenção, elaboração de um Plano Diretor de Investimentos (PDI) para corrigir lacunas assistenciais etc.

Essa norma faz parte da agenda futura da descentralização e, apesar de propor ênfase na regionalização como necessária "para o aprofundamento do processo de descentralização", é uma norma que poderá reduzir, ao menos em parte, a autonomia de gestão conquistada pelos municípios com a NOB SUS 01/96. Esse tema será objeto de reflexão no capitulo final desse trabalho, na análise dos desafios para a nova agenda da descentralização da saúde.

\subsection{Contexto recente do processo de municipalização}

Como de certa forma previram BUENO e MERHY ${ }^{19}$ (1998), os municipios estão aderindo ao PACS e ao PSF. O período mais recente da descentralização da saúde no Brasil tem-se caracterizado pela expansão desses dois programas. O Programa de Agentes Comunitários de Saúde contava em maio de 1998 com 64.776 agentes. Em maio de 2000 o número de agentes passou para 125.993, que atuavam em 4.330 municípios e em todas as regiões do país (BRASIL $\left.{ }^{17}, 2.000\right)$. 
O Programa de Saúde da Família também teve crescimento rápido. As equipes desse programa, constituída cada uma por médico, enfermeiro, auxiliares de enfermagem e agentes comunitários de saúde, somavam 1.992, em maio de 1998. Em janeiro de 2000 já existiam 5.139 equipes, em 1.931 municipios. A expansão continuou, chegando em julho de 2000 a 7.291 equipes, em 2.438 municípios (BRASIL ${ }^{17}, 2000$ ). As metas atuais são de 20.000 equipes de PSF, propiciando a cobertura de 69 milhões de pessoas até o ano 2002.

A expansão do PACS e do PSF deu-se especialmente em decorrência de incentivos financeiros do Ministério da Saúde, que agregou valores ao Piso da Atenção Básica (PAB) para contribuir com o financiamento dos programas; as perspectivas são de continuidade nessa expansão, como mostra a publicação pelo Ministério da Saúde da Portaria $n^{0} 1329$ (BRASIL $^{13}$, 1999). Essa portaria, de 12 de novembro de 1999, amplia ainda mais o incentivo financeiro ao PSF, ao autorizar o pagamento das equipes implantadas de forma proporcionalmente maior à cobertura populacional. Os municípios que alcançarem, por exemplo, cobertura de mais de $50 \%$ de sua população com a Saúde da Familia, receberão mais por cada equipe do que aqueles que tiverem uma cobertura menor do que $50 \%$.

A magnitude que esse incentivo financeiro representa é significativo no atual contexto de financiamento federal da saúde. Essa cobertura é calculada pela fórmula $C=(E \times 3450) / P) \times 100$, na qual $C$ é a cobertura, $E$ é o número de equipes e $\mathrm{P}$ é o número de habitantes do municipio. No municipio em que a cobertura for igual ou superior a $70 \%$, os valores de incentivo serão de $R \$ 54.000,00$ ao ano por equipe implantada. Como cada uma dessas equipes é responsável por cerca de 3.450 pessoas, referencial estabelecido pelo Ministério da Saúde, os valores de incentivo per capita alcançam em torno de $\mathrm{R} \$ 15,00 / a n o$, superiores ao do próprio piso de atenção básica, que é próximo de $R \$ 12,00 / a n o$. Explicando de outra forma, 
o município que se encontra em gestão plena de atenção básica e implanta o PSF, com cobertura de $70 \%$ de sua população, recebe aproximadamente o dobro de recursos federais sob a forma de repasse direto, em seu fundo municipal de saúde. Além disso, recebe incentivos adicionais de implantação (cerca de $\mathrm{R} \$ 10.000,00$ por equipe) e por agente comunitário de saúde (ACS) de $\mathrm{R} \$ 2.200,00 / \mathrm{ACS} / \mathrm{ano}$.

Estes dados foram apresentados com minúcia para exemplificar a maior influência do Ministério da Saúde no direcionamento do processo de descentralização, no final dos anos 90.

Estarão representado essas medidas uma restrição maior à liberdade de formulação das politicas locais de saúde?

Consideramos que o reforço ao PACS e ao PSF nessa magnitude está exercendo forte influência na descentralização, objetivo que parece ser o do Ministério da Saúde, como se pode verificar no documento: "Saúde da Familia: uma estratégia para a reorientação do modelo assistencial", no qual se reconhecem os avanços nas reformas administrativas, políticas e organizativas, por conta da descentralização que está em curso, e se dá ênfase à democratização da gestão, mas se considera que "no entanto, por si só, essas realizações não foram ainda suficientes para transformar a prática sanitária brasileira e suas reais condições de garantir a melhoria da qualidade de vida e saúde dos cidadãos brasileiros" (BRASIL ${ }^{12}, 1997$ ). Para essa transformação das práticas sanitárias, segundo os documentos oficiais do Ministério da Saúde, a estratégia dos agentes comunitários de saúde e da saúde da familia passam a constituir o ponto central.

Alguns estudos procuraram analisar o potencial transformador dos programas PACS e PSF, na reorientação das práticas sanitárias e mudança do modelo assistencial. PAIM"4 (1999) afirma que "mantidos o caráter de programa especial e a gestão verticalizada, através das coordenações 
nacional, estadual e municipal, o PACS e o PSF podem comprometer esforços genuínos de municipalização" (p.499); ressalta aspectos e exemplos positivos dos programas, mas considera que ainda não existem evidências que caracterizem esses programas como estratégia suficiente para mudança dos atuais modelos.

Alguns autores têm defendido o PSF como a estratégia de reorganização da atenção primária da saúde, em nosso país. MENDES ${ }^{81}$ (1996, p.281), por exemplo, destaca alguns aspectos positivos em experiências do PSF, tais como aumento da resolubilidade, diminuição das internações hospitalares, mudança do perfil de morbidade hospitalar e maior satisfação da clientela. Ressalta esse autor, porém, que, como resultado da ampliação do PSF, induzida pelo incentivo financeiro do Ministério, foram implantadas muitas experiências que, "apesar do nome de Programa de Saúde da Familia", nada têm de estratégia de reorientação das práticas sanitárias na área da atenção básica.

Como a estratégia do PSF é um processo recente, ainda é necessário algum tempo para avaliar seus resultados. Existem algumas discordâncias, porém, entre parcelas do movimento sanitário, especialmente daquelas que defendem outras propostas de inversão do modelo assistencial, ou das que consideram a autonomia do poder local um fator indispensável para o êxito da descentralização.

O final dos anos 90 aponta para uma redução dessa autonomia?

Consideramos que, se o PSF for utilizado como estratégia de mudança do modelo assistencial como propõem diversos autores, e não como um programa vertical do Ministério, não provocará, necessariamente, uma redução da autonomia local, pois poderá ser adaptado a cada realidade municipal. Deve-se entendê-lo, segundo propõe SOUZA ${ }^{112}$ (2000, p.15), como estratégia estruturante de reorganização da atenção básica, que só se 
viabilizará se produzir mudanças nas práticas sanitárias, construindo novos vínculos entre os serviços de saúde e a população. Persistem, no entanto, divergências a respeito da efetividade dessa estratégia, que será melhor abordada no capitulo final.

\section{O CONTEXTO ECONÔMICO}

É necessário ressaltar a dualidade que envolve a descentralização da saúde no pais, já abordada anteriormente, e de como ela se manifesta no presente momento. Os últimos governos têm reiterado os propósitos de priorizar metas económicas, que cujo principal objetivo é promover o ajuste fiscal do Estado; isso reouz, como afirma FIORI" ${ }^{45}$ (1997, p. 212) "o espaço de exercicio das politicas públicas". Para esse autor, dividindo as políticas públicas em três grandes campos, o macroeconômico, o das políticas industriais e o das politıcas sociais, verifica-se o seguinte: (1) o campo macroeconômico, num mundo globalizado em que os eixos de poder se afastam cada vez maıs dos países individualizados, é comandado por distintos fatores e poderes que fogem cada vez mais do espaço de governabilidade do pais; (2) as politicas industriais sofrem influências da abertura comercial radical e do câmbio, requisitos da nova ordem econômica internacional para os paises que se alinharam, como é o caso do Brasil, eliminando o campo de atuação do governo, e (3) as políticas sociais, por sua vez, encontram-se limitadas pela impossibilidade de mexer na parte financeira da divida pública.

Os reflexos mais visiveis dessa situação traduzem-se na redução dos gastos federais na maioria das áreas sociais. Para citar alguns exemplos, na área de habitação e urbanismo o governo federal gastou, em 1996, cerca de oito vezes menos, e na área de saneamento e meio ambiente, cerca de quatro vezes menos, em valores corrigidos, do que gastava no inicio da década de 1980. A expressiva elevação dos gastos com assistência e previdência social, que aumentou, também em valores corrigidos, mais de 
$70 \%$, nos últimos 20 anos, consome a maior parte dos recursos da Seguridade Social (OLIVEIRA JÚNIOR ${ }^{11}, 1998$ ).

Na área da saúde, apesar de pequena recuperação nos gastos federais, se comparados com os dos primeiros anos da década de 1990, os valores não eqüivalem, em relação aos valores per capita, aos de 1989. A proposta de vinculação de recursos orçamentários federais e de estados e de municipios para a saúde (Emenda Constitucional 29) encontrou barreiras políticas para sua aprovação definitiva, que foram superadas com a votação favorável no Senado Federal em agosto de 2000. Sua recente aprovação foi um fator positivo a se refletir no ano de 2001, mas não representará mudança tão substancial nesse quadro de gastos, a não ser para a esfera estadual. Para o conjunto das áreas sociais não se vislumbra alteração na tendência de retração nos gastos, já que sua isso dependeria de alterações estruturais da economia, dificilmente realizáveis no atual contexto político e econômico.

Entre os protagonistas da Reforma Sanitária, observa-se uma situação distinta daquela observada quando dos embates políticoideológicos da primeira metade da década de 1990. Naquele período, a união dos distintos atores favoráveis à implantação da Reforma Sanitária e do SUS dava-se em torno de bandeiras políticas de clara visibilidade, tais como a aprovação da Lei Orgânica da Saúde e o cumprimento da legislação através de normas operacionais. O princípio de identidade do movimento sanitário estava fortalecido porque os opositores da implantação do SUS eram mais visíveis. A luta pelo restabelecimento do Estado de Direito e a construção de condições jurídicas e legais para a nova política de saúde aglutinavam os atores do movimento sanitário. No final da década o movimento ficou mais fragmentado em sua luta política. Os momentos de consenso quanto à estratégia de luta que mais aglutinam ocorrem com as mobilizações por melhoria do financiamento para a saúde, tais como as que 
ocorreram nos últimos anos, em conseqüência das pressões exercidas sobre o Congresso Nacional.

Consideramos que o foco da luta política se deslocou um pouco mais para as arenas locais, no campo da experimentação de novos modelos assistenciais, alternativos ao modelo médico-assistencial privatista. Essas estratégias passaram a ocupar a agenda do movimento sanitário. A luta contra o Estado neoliberal, a convivência com ele ou o apoio ao mesmo passaram a constituir agenda de partidos politicos e de outros movimentos sociais.

$\mathrm{Na}$ análise do contexto atual, é importante ressaltar alguns aspectos da dualidade existente entre a política econômica e a política de saúde. Enquanto a política econômica tem sua agenda ocupada com as metas do ajuste fiscal, como comentamos, deve-se reconhecer que a política de saúde, tanto neste governo quanto nos anteriores, a partir do término do governo Collor, tem procurado "lutar contra essa maré". Mesmo constituindo política contra-hegemônica, a politica da saúde tem-se caracterizado por manter articulação razoável com a reforma sanitária.

Além das políticas de incentivo à reorganização do sistema de saúde, percebem-se esforços políticos do setor saúde no sentido de regulação do setor privado nas áreas de medicamentos e insumos, planos de saúde, propaganda e marketing, entre outros.

Nesse contexto econômico e político a municipalização da saúde no Brasil sofreu influências, também, da pletora de municípios que foram criados após a Constituição de 1988. O expressivo aumento de municípios na década de 1990, determinado na maioria das vezes por interesses de grupos e facções politicas, transfere responsabilidades de gestão para muitos governos locais despreparados para cumprir seus deveres constitucionais. Apesar de ter ressaltado os direitos do cidadão e os deveres 
do Estado, a Constituição pouco avançou na efetivação de direitos e deveres da cidadania. Os governos não cumprem as leis, como ocorre freqüentemente nas mais diversas áreas e não apenas na da saúde, e não existem mecanismos consolidados para exigir que esses direitos sejam respeitados.

É necessárin reafirmar a agenda do movimento sanitário, no qual se destacam: democratização da gestão; resgate da cidadania; incorporação de excluídos; controle social e substituição do atual modelo de saúde pelo SUS, com integralidade, equanimidade e qualidade. Os avanços na agenda dependem, por um lado, como afirma ESCORt ` (1998, p. 194), de entender que "o inimigo comum do movimento sanıarı está identificado nas diversas facetas que o projeto neoliberal em saúde assume, tanto em seus diferentes âmbitos governamentais quanto em suas diversas práticas assistenciais. Não há qualquer possibilidade de acordo entre práticas tão distintas em seus principios fundamentais".

Além disso, pensamos nós, é também necessário construir um consenso sobre as estratégias de mudança. Não exıstem dúvidas de "onde se quer chegar". A imagem-objetivo é o "SUS democrático", que personifica os princípios da Reforma Sanitária brasileira. As dúvidas existem quando se buscam formas de "como chegar" ao objetivo.

O estudo do local, avaliando a experimentação de modelos assistenciais em curso no processo de municipalização da saúde de forma contextualizada com o momento histórico e politico, poderá contribuir para esclarecer algumas dessas dúvidas. É necessário conhecer os limites e as possibilidades de implementação de mudanças decorrentes do processo de municipalização da saúde para aperfeiçoar as estratégias políticas e operacionais do SUS. 
Um dos objetivos deste capitulo foi analisar a municipalização da saúde procurando ressaltar a importância do estudo do espaço local de poder na implantação do SUS. Este trabalho propõe-se a estudar alguns aspectos do processo decisório local, com a finalidade de contribuir para o esclarecimento de algumas das muitas dúvidas relativas ao processo de municipalização da saúde. É no espaço local de poder que se dá a experimentação de novos modelos assistenciais e se materializam as contradições entre o local e o geral. Os conceitos relacionados ao poder local serão objeto do próximo capítulo. 


\section{CAPÍTULO 2}

\section{PODER LOCAL}

O processo de municipalização da saúde no pais trouxe novas responsabilidades aos governos locais. A Lei Orgânica da Saúde, 8.080, de 19 de setembro de 1990 , em seu artigo 18, especifica a competência dos mur zipios:

Art 18. À direção municipal do Sistema Único de Saúde - SUS compete:

I - planejar, organizar, controlar e avaliar as ações e os serviços de Saúde e gerir e executar os serviços públicos de Saúde;

II - participar do planejamento, programação e organização da rede regionalizada e hierarquizada do Sistema Único de Saúde - SUS, em articulação com sua direção estadual;

III - participar da execução, controle e avaliação das ações referentes as condições e aos ambientes de trabalho;

IV - executar serviços:

a) de vigilância epidemiológica;

b) de vigilância sanitária;

c) de alimentação e nutrição;

d) de saneamento básico; $e$

e) de Saúde do trabalhador.

$V$ - dar execução, no âmbito municipal, à política de insumos e equipamentos para a Saúde;

VI - colaborar na fiscalização das agressões ao meio ambiente que tenham repercussão sobre a saúde humana e atuar, junto aos órgãos municipais, estaduais e federais componentes, para controlálas;

VII - formar consórcios administrativos intermunicipais;

VIII - gerir laboratórios públicos de saúde e hemocentros;

IX - colaborar com a União e os Estados na execução da vigilância sanitária de portos, aeroportos e fronteiras;

$X$ - observado o disposto no artigo 26 desta Lei, celebrar contratos e convênios com entidades prestadoras de serviços privados de saúde, bem como controlar e avaliar sua execução;

XI - controlar e fiscalizar os procedimentos dos serviços privados de saúde;

XII - normatizar complementarmente as ações e serviços públicos de saúde no seu âmbito de atuação. 
Essas responsabilidades não ficaram restritas apenas aos governantes municipais, como já foi comentado no capítulo 1, mas também se estenderam a outros atores locais, que no seu conjunto compõem o que se costuma denominar poder local. A legislação vigente dispõe sobre a participação da comunidade na gestão local do Sistema Único de Saúde através da Lei n. ${ }^{\circ}$ 8.142, de 28 de dezembro de 1990. Essa Lei refere-se à "participação colegiada na gestão da saúde" e assinala em seu artigo primeiro:

Art. $1^{\circ}$. O Sistema Único de Saúde - SUS de que trata a Lei n. ${ }^{\circ} 8.080$. de 19 de setembro de 1990, contará, em cada esfera do governo sem prejuizo das funções do Poder Legislativo, com as seguintes instâncias colegiadas:

I - a Conferência de Saúde; e

II - o Conselho de Saúde.

$\S I^{\circ}$. A Conferência de Saúde reunir-se-á a cada 4 (quatro) anos com a representação dos vários segmentos sociais, para avaliar a situação de saúde e propor as diretrizes para a formulação da política de saúde nos niveis correspondentes, convocada pelo Poder Executivo ou, extraordinariamente, por este ou pelo Conselho de Saúde.

$\S 2^{\circ}$. O Conselho de Saúde, em caráter permanente e deliberativo, órgão colegiado composto por representantes do governo, prestadores de serviço, profissionais de saúde e usuários, atua na formulação de estratégias e no controle da execução da política de saúde na instância correspondente, inclusive nos aspectos econômicos e financeiros, cujas decisões serão homologadas pelo chefe do poder legalmente constituido em cada esfera de governo.

$\S 3^{\circ}$. O Conselho Nacional de Secretários de Saúde CONASS e o Conselho Nacional de Secretários Municipais de Saúde - CONASEMS terão representação no Conselho Nacional de Saúde.

$\S 4^{\circ}$. A representação dos usuários nos Conselhos de Saúde e Conferências será paritária em relação ao conjunto dos demais segmentos.

$\S 5^{\circ}$. As Conferências de Saúde e os Conselhos de Saúde terão organização e normas de funcionamento definidas em regimento próprio, aprovadas pelo respectivo Conselho.

O marco legal do Sistema Único de Saúde, como se vê, é bastante claro no sentido de delegar responsabilidades aos atores locais, governantes e população, na gestão da saúde. A operacionalização dos dispositivos legais através da criação das formas de gestão semiplena, em meados da década de 1990 e plena da atenção básica, e plena do sistema municipal, 
alguns anos depois, permitiu que fossem construidas bases empíricas para analisar a influência do poder local nessas novas formas de gestão. Essa influência tem, evidentemente, restrições e limites em sua capacidade de intervenção e de mudança das práticas sanitárias. Esses limites necessitam ser melhor conhecidos para que as estratégias de gestão local da saúde possam ser potencializadas.

\subsection{Conceitos}

Tanto os governos locais quanto o chamado poder local têm dificuldades e constrangimentos impostos pela legislaçāo nacional, que limitam o seu poder na condução das políticas de saúde. Para a análise desse tema é indispensável considerar, primeiramente, o significado dos termos "poder", "local" e "poder local", que serão utilizados neste estudo.

\section{PODER}

BOBBIO $^{5,6}$ (1986, p.955; 1999, p.82-5) classifica o poder nas sociedades modernas em três grandes classes: econômico, ideológico e político. O poder econômico vale-se da posse de determinados bens a induzir os que não o possuem e dele necessitam, a adotar o comportamento que os que o detêm, desejam. O poder ideológico utiliza a influência das idéias, que "expressas e definidas sob certas circunstâncias e mediante certos processos" influenciam a conduta dos que dela são alvos. O poder político é aquele que pode recorrer à força para fazer prevalecer sua vontade.

LOCAL

O local coincide com o espaço municipal e mais freqüentemente com o ambiente restrito às cidades. Seus limites, porém, não devem ser entendidos no âmbito puramente territorial ou geográfico. Correspondem não só a determinado espaço físico, mas têm os seus limites estabelecidos a 
partir das relações entre os grupos e atores sociais que interagem nesse espaço.

PODER LOCAL

O poder local, entendido como poder que emana dessa rede de relações que se estabelece no "local", constitui um tema complexo, que tem sido tratado na literatura a partir de diferentes perspectivas. Referindo-se à complexidade do estudo do poder local, FISCHER ${ }^{47}$ (1997, p.10) considera que o poder local requer tratamento "no minimo multidisciplinar", em que "sociólogos, antropólogos, geógrafos, administradores, economistas, comunicadores" observem o local "com seus instrumentos e referenciais de análise".

Nos estudos sobre o local e o poder local, conseqüentemente, devem ser evitadas simplificações ou reduções, já que estas podem ter como resultado apenas visões parciais de uma realidade complexa. Os propósitos deste capitulo referem-se à análise dos limites do local e, por extensão, de suas possibilidades e desafios, na mudança das práticas sanitárias em decorrência da municipalização da saúde. Considerando a complexidade do assunto, isso não constitui uma tarefa fácil.

É necessário ressaltar que uma das primeiras preocupaçōes deste estudo é o de não tomar partido por qualquer das duas visōes polares freqüentemente encontradas na literatura do setor saúde, sobre a análise do local: sua supervalorização ou sua negação. Os que supervalorizam o local, especialmente alguns segmentos da chamada corrente municipalista, consideram que esse ambiente constitui um cenário passivel de grandes transformações sociais e políticas. Os que negam, absolutamente, o local, por outro lado, preferem retirar qualquer possibilidade transformadora do poder local. Para esses, os determinantes da realidade local estão no âmbito das estruturas social, política e econômica mais amplas da sociedade e do 
Estado, e a capacidade de intervenção do poder local nessa realidade é nula.

Parece-nos, como mostram os resultados de diversos estudos, citados neste capítulo, que nenhuma dessas duas visões polares é correta. Existe mútua interferência entre o "central" ou "global" e o "local". Não é possivel analisar as políticas locais sem considerar os determinantes sociais, econômicos, politicos e culturais mais amplos. Por sua vez, também é preciso reconhecer que os grupos locais, através do exercicio do poder local, podem influenciar no direcionamento das politicas de saúde.

Analisamos neste capitulo os seguintes temas: (1) os governos locais: constrangimentos institucionais e legais; (2) o poder local e a representação de interesses; (3) as incongruências da Constituição Federal de 1988 no Brasil, e (4) a participação da sociedade na politica. Nosso objetivo foi o de, com base nas informaçōes relacionadas, analisar o problema e suscitar reflexōes que possam contribuir para o conhecimento dos limites e das possibilidades do poder local no processo de municipalização da saúde.

\subsection{Os governos locais: constrangimentos institucionais e legais}

Os governos locais, que, no caso do Brasil, equivalem às administraçōes municipais, possuem autonomia para o exercício do poder limitada pela legislação pertinente. Essa autonomia depende basicamente de dois fatores: (1) das relações entre os governos eleitos e os atores locais (cidadãos e diversos grupos locais); (2) das relações entre os governos eleitos e os governos central e subcentral (governos estaduais, por exemplo) 
RELAÇÕES ENTRE OS GOVERNOS ELEITOS E OS ATORES LOCAIS

Como afirmam BOWMAN e $\operatorname{HAMPTON}^{7}$ (1989, p.333-334) as relações existentes entre os governos eleitos e os atores locais podem situar-se em dois pólos distintos: dominante e pluralista.

$\mathrm{Na}$ forma dominante, o governo local desempenha suas atividades com autonomia e independência dos atores locais. A influência do meio social e político local nas decisões de governo não se dá dentro da estrutura formal de poder. O exercício da autoridade local é puramente governamental. Os governos dominantes costumam ter independência também em relação aos outros niveis de governos, central e subcentral.

Na forma pluralista, por outro lado, o contexto formal do exercício de poder local terá influéncia dos outros atores do espaço local e também de outros niveis de governo Nesses governos a representação de interesses no processo politico local tem espaços para manifestar-se no interior da estrutura formal do govemo.

Segundo esses autores, as formas dominante e pluralista dificilmente existem em estado puro. Na prática, costumam existir governos locais predominantemente dominantes ou predominantemente pluralistas, na dependência da legislaçåo e da cultura política de cada país.

RELAÇÕES ENTRE OS GOVERNOS ELEITOS E OS GOVERNOS CENTRAL E SUBCENTRAL

As relações entre os governos locais e os outros niveis de governo se diferenciam nos denominados estados federais e estados unitários. As relações intergovernamentais, a distribuição de funções entre os niveis de governo e o financiamento de que podem dispor os governos locais são diferentes para os paises onde predomina uma ou outra dessas duas formas de governo. 
O federalismo, caracteristica dos estados federais, é uma "forma de governo pela qual vários estados se reúnem numa só nação, sem perderem sua autonomia fora dos negócios de interesse comum" (FERREIRA $\left.{ }^{44}, 1986\right)$. Nos países com sistemas políticos federais, tais como Canadá, Austrália e EUA por exemplo, existe uma maior cooperação política e financeira entre o governo federal e as demais esferas da federação.

Nesses paises, a descentralização das funções ou competências do governo central costumam se dar das instâncias centrais de poder para os outros niveis de governo mais periféricos, dispersos nas suas divisర̋es territoriais. Esse tipo de descentralização, denominada descentralizaçåo territorial, já analisada no capitulo 1, é compativel com o federalismo, pors nesses sistemas políticos os dispositivos legais que permitem essa transferência de poder e de responsabilidades estão previstos constitucionalmente.

Nações unitárias, tais como Inglaterra, Japão e Nova Zelândia por outro lado, têm em geral poder mais centralizado e a identidade dos estados e municipios é menos individualizada. Nesses paises existem transferências de serviços ou de competências dentro de limites que mantêm essas funções dentro da esfera de ação do Estado central. Essa descentralização, denominada funcional, também analisada no capítulo 1 , não ocasiona efetiva transferência de poder, sendo por isso mais apropriada a esse tipo de governo (TEIXEIRA ${ }^{121}$ 1990, p.84).

Não existe distinção precisa e clara entre estados unitários e federais quanto à descentralização de poder. Segundo VIEIRA (apud TEIXEIRA ${ }^{121}$, 1990), a concepção de que só os países federados podem ser efetivamente descentralizados não corresponde à realidade. De acordo com os estudos desse autor, o grau de descentralização de um país não depende apenas do que diz sua constituição, mas também de fatores ligados aos interesses econômicos e tecnológicos, que influem, igualmente, na distribuição de 
poder. Como há, no entanto, várias definições e vários entendimentos sobre o conceito de descentralização, como foi comentado no capítulo 1, é possivel correlacionar os estados federais como, ao menos, mais permeáveis à descentralização, que acarreta "devolução de poderes" às instâncias locais, pois nesses estados existem dispositivos legais que favorecem essa forma de descentralização.

Alguns autores, entre os quais CLARKE e STEWART ${ }^{32}$ (1991, p.5456), BOWMAN e HAMPTON ${ }^{7}$ (1989, p.328) e SOUZA'"' (1996, p.104), têmse dedicado a estudar esse assunto, classificando a relação entre os governos central e local em alguns modelos. Nos países desenvolvidos identificam-se basicamente três formas, apesar de que dificilmente essa relação corresponda a modelos puros, havendo predomínio de um deles, mas, em geral, está presente mescla dos três: (1) os governos locais têm autonomia relativa, podem tributar e formular politicas e o controle central baseia-se fundamentalmente na legislação reguladora; (2) os governos locais constituem-se como agências de implementação das políticas do governo central, podem sofrer intervenções freqüentes e existe pouca justificativa para liberdade de taxação, e (3) a relação entre as duas instâncias se dá de forma complexa, existindo uma mútua interferência numa situação em que o processo político local e central estão interrelacionados, sendo difícil identificar responsabilidades de níveis particulares.

Estudos de caso realizados em paises industrializados estão detectando a tendência de ampliação do controle central, com motivações ideológicas ligadas a fatores econômicos e políticos.

A existência de um governo local implica em que ele atenda a determinadas caracteristicas que the dêem alguma individualidade. BOWMAN e HAMPTON ${ }^{7}$ (1989) definem os governos locais como "instituições que estão constituidas por alguma forma de procedimento 
democrático, que desfrutam de fonte independente de recursos (tributos), ao menos para uma parte de seus gastos, e que tem certo grau de autonomia para buscar políticas que possam estar relacionadas com a de outros governos subnacionais, ou com prioridades estabelecidas pelo governo central" (p.326).

EMBATE ENTRE OS FEDERALISTAS E OS DEFENSORES DO ESTADO UNITÁRIO, NO BRASIL

A capacidade de influència dos governos locais está relacionada com o seu grau de autonomia e indıvidualidade. A opção de dar maior ou menor poder aos estados e munıcıpıos está condicionada a determinantes históricoculturais e politicos de cađa pais, e as publicações que tratam desse assunto para os países desenvolvidos, ressaltando o alcance do poder dos governos locais nesses paises. dificilmente se aplicam ao Brasil. A questão da autonomia dos governos locais, na história do nosso país, fez parte do embate ideológico e politico entre os defensores de estados unitários e do federalismo.

Segundo $\mathrm{MELO}^{79}$ (1993), a critica à centralização polịtica e a defesa do federalismo remontam ao periodo do Império, no Segundo Reinado. De acordo com esse autor, levantando a tese da autonomia municipal e provincial, pensadores liberais passaram a defender a descentralização política e administrativa do Império, criticando o modelo monárquico "unitarista e centralizador, de inspiração francesa, adotado no país" (p.86). Nesse contexto, passam a surgir construções intelectualmente bem acabadas, tendo como foco temas como "municipalismo", "federalismo" e "libertação dos municipios", entre outros

No inicio do século $X X$ podiam ser identificadas posições de crítica à doutrina municipalista e de defesa da centralização politica, não por considerar que o modelo centralizador tem virtudes, mas por temer a manipulação do poder por oligarquias locais. Aqueles que defendiam essas 
posições eram contrários à descentralização do poder, pois considercivam que os grupos dominantes locais, utilizando a condição privilegiada de que dispunham nos seus municípios, submeteriam o poder público local aos seus interesses particulares.

Situado entre os que criticavam a doutrina municipalista, Oliveira Vianna (apud SADEK ${ }^{104}$ 1991, p.13), nas décadas de 20 e 30, considerava que a questão de fundo da doutrina municipalista, defensora do federalismo, era a submissão do Estado a interesses privados, presentes nos chamados "feudos municipais", dominados pelos "coronéis" da política tradicional. Os críticos do federalismo consideravam que "o pais estava dividido entre pequenos tiranos locais, sem escrúpulos, desatentos aos interesses da população" (HOCHMAN ${ }^{5 s} 1998$, p.72). O federalismo, adotado pela Constituição de 1891, constituia, segundo esses criticos, um dos fatores que dificultavam a solidariedade e a cooperação.

Para alguns defensores do federalismo, por outro lado, a viabilização de políticas mais eqüitativas não seria obtida com a centralização. Sem discordar, fundamentalmente, da existência de um domínio político local por elites descomprometidas, propunham a descentralização como estratégia de romper com esse domínio. Essa sofisticada concepção das relações de poder, mais visível a partir da década de 1950, surge com a obra Coronelismo, Enxada e Voto, de Victor Nunes Leal (SADEK ${ }^{104}$, 1991), que identifica um "pacto não escrito entre o poder central e os chefes locais, (que) longe de ameaçar o poder público, acaba por torná-lo presente nos pontos mais distantes do território nacional." Essa posição deixava claro que a ampliação da autonomia municipal não era a causa da privatização do Estado pelas oligarquias políticas locais. A verdadeira causa era a forma pela qual era exercida essa autonomia. O domínio politico local nas mãos de uma oligarquia retrógrada e a conseqüente utilização do poder público para seus benefícios só poderiam ser combatidas, segundo Victor Nunes Leal, por intermédio da autonomia municipal. Entendendo-se a autonomia, nesse 
caso, como a possibilidade de fragmentação do poder oligárquico, distribuindo-o a outros atores locais, ou seja, democratizando-o

Na década de 1950, a urbanização reduziu a força do "coronelismo". Essa politica tradicional, que persistiu e persiste até hoje em alguns municípios pequenos, em agrupamentos rurais e, mesmo, em "feudos urbanos" de municipios maiores, passou a sofrer entraves institucionais a partir desse período. Posteriormente, o regime burocrático-autoritário de 1964, fortemente centralizado, interrompeu o embate entre defensores do federalismo e do estado unitário, que retornou com a abertura politica e com a outorga da nova Constituição, de 1988, francamente favorável aos defensores do federalismo. Movimentos municipalistas de caráter mais setorial, como é o caso da saúde, deram importante contribuição nesse sentido, especialmente em virtude de sua capacidade de articulação com amplos setores políticos e sociais (GOULART ${ }^{52}, 1996$ ).

\subsection{Poder local e representação de interesses}

Os diversos atores que interagem no espaço local não tem, evidentemente, os mesmos interesses. Esses distintos interesses organizam-se a partir de estratégias que esses atores constroem, consciente ou inconscientemente, no processo de interação. A capacidade de interferência do poder local pode ser considerada como a resultante dos interesses que são representados nesse processo.

A concepção de como se organizam esses interesses e, conseqüentemente, de como se constitui e se manifesta o poder local, pode ser considerada a partir de diferentes enfoques teóricos. Ou seja, existem diferentes formas de compreensão do significado de poder local, que dependem basicamente da compreensão que se tem da realidade social. Como analisar a realidade social local? 
CASTRO $^{26}$ (1988, p.56) aponta as questões que devem ser respondidas na análise dessa realidade: (1) a natureza do poder local nas condições do capitalismo avançado; (2) as relações desse poder com a estrutura econômica, o Estado e os distintos níveis de poder e estruturas decisórias; (3) os constrangimentos de várias ordens - sócio-econômicos, burocráticos e institucionais - que delineiam o perfil de intervenção no nivel local; (4) os efeitos do processo de urbanização sobre a implementação de politicas sociais; (5) quais os mecanismos de intermediação de interesses e a influência que os mesmos sofrem de fatores politicos, e (6) a influência da tradição político-partidária e o grau de participação política sobre o processo de tomada de decisões.

Diversos estudos trataram dessas questões. Segundo FISCHER (1991), eles se orientam basicamente por dois pólos distintos: (a) a análise das estruturas, politicas e ações de governo, e (b) a ação dos movimentos sociais. No tópico anterior analisamos os aspectos legais (constituições, leis e práticas de governo); agora nos interessa considerar as estruturas políticas e, mais à frente, ainda neste capítulo, discutir os aspectos relacionados com a participação da sociedade.

As estruturas politicas locais podem ser compreendidas de diferentes formas. Isto se dá, fundamentalmente, em função de como se interpretam as relações entre a sociedade e o Estado. Essas relações podem ser interpretadas a partir de três grandes matrizes teóricas - pluralista, neocorporativista e marxista (LOBATO ${ }^{61}$, 1997; COUTINHO ${ }^{38}, 1989$; CASTRO $^{26}, 1988$ ) - as quais analisamos a seguir, com o objetivo de compreender como os diversos interesses se fazem representar, em cada uma, no âmbito do poder local. 
PLURALISMO: PLURALISTAS E ELITISTAS

A teoria pluralista considera que o jogo político se faz a partir de diferentes grupos de interesse que disputam entre si o poder. Segundo essa teoria, os grupos mais fortes do espaço local conseguem fazer prevalecer seus interesses, em detrimento dos grupos contrários. Essa "disputa" é intermediada pelo processo eleitoral, que garante o equilibrio entre os grupos, ao impedir que aqueles que têm maior poder econômico exerçam também maior poder político no processo de formulação das decisões de governo (VAITSMAN, 1988 p.145 apud LOBATO ${ }^{61}, 1997$ p.31)

O pluralismo recebeu forte influência das teorias norte-americanas. Seus adeptos discordam de uma distribuição desigual ou piramidal do poder local, ou seja, não consideram a existência de grupos locais que possam, a priori, ocupar posições privilegiadas em decorrência de sua posição na estrutura social; por esse motivo não se preocupam em pesquisar a estrutura do poder local. Para os pluralistas, o processo de tomada de decisões deve ser analisado em seus vários campos, onde se estabelecem disputas entre os grupos que procuram influenciar o governo para fazer valer seus interesses; o governo faz o papel de intermediador e aliviador de conflitos, procurando fazer prevalecer o interesse público que esteja acima dessas disputas.

A partir da década de 1970, o pluralismo sofreu modificações em sua concepção de poder, passando a reconhecer que nem sempre o plano de decisão das políticas públicas está acima dos interesses dos grupos em disputa. Conseqüentemente, a intermediação do governo nem sempre se coloca como uma força amoral e descompromissada com esses interesses. No entanto, de acordo com LABRA (1990) apud LOBATO ${ }^{61}$ (1997), porém, apesar dessa mudança em sua concepção, o pluralismo nunca se afastou concretamente de sua matriz teórica original, que insiste em não reconhecer uma desigualdade estruturalmente determinada nas relações de poder entre os vários grupos sociais. 
O pluralismo tem origem no liberalismo. Identificava-se nessa doutrina, desde o século $X \mid X$, a preocupação de que uma disputa entre interesses diversos pudesse fazer prevalecer os interesses de uma possivel maioria contrária à ordem capitalista. A ampliação dos direitos politicos, de acordo com essa preocupação, poderia fazer com que. numa situação de múltiplas representaçōes de interesses, a maioria pudesse eliminar a liberdade, ao exercer um poder despótico sobre as minorias.

A teoria liberal mais recente passou a tentar mostrar que em decorrência da fragmentação dos interesses, dispersos no meio social, e de uma natural apatia politica da maioria, nunca se formam maiorias estáveis Esses liberais tentaram evidenciar que, na prática, a politica não é exercida pela maioria, mas por "várias pequenas elites" que acabam por representar múltiplos interesses. Essa é a concepção que fundamenta o pensamento dos elitistas. A democracia, na visāo de elitistas como Schumpeter (apud COUTINHO 3x 1989, p.58) "nāo passa de um método procedimental para selecionar elites por meio de eleiçōes periódicas"

Para a teoria elitista, o processo eleitoral não corresponde a uma manifestação de interesses diversos, mas a um método de escolha de lideres que passam a ter a delegação de decidir e governar. De acordo com elitistas clássicos, como Schumpeter, a politica envolve compromissos entre elites, pois o cidadão comum não tem o necessário discernimento, competência e racionalidade para tomar as decisões mais acertadas.

As divergências entre os pluralistas e os elitistas estão muito presentes nos estudos publicados sobre representação de interesses e poder local, especialmente aqueles realizados nos EUA a partir da década de 1960. Na análise do processo decisório local, enquanto os pluralistas consideram que grupos de interesse diversos conseguem articular-se na defesa de seus interesses especificos, os elitistas admitem que è necessária 
uma seleção dos mesmos, por elites dirigentes, para garantir a implementação de mudanças.

Essas críticas dos elitistas ao pensamento pluralista fundamentam-se numa concepção de não-responsividade das estruturas decisórias locais às demandas do conjunto dos cidadãos, havendo necessidade, portanto, de uma instância dirigente privilegiada (TEIXEIRA ${ }^{120}$ 1998, p 41: CASTRO ${ }^{26}$ 1988, p.57; STOCKER ${ }^{118}$ 1991, p.118-119). Apesar dessas divergências, o elitismo é originário da mesma doutrina social do pluralismo o liberalismo. Ambas podem ser situadas nessa mesma matriz teórica, pors têm como principal característica não reconhecer a existência de contradições na estrutura social, no que se refere à distribuição do poder.

\section{NEOCORPORATIVISMO}

O neocorporativismo surge, especialmente, em decorréncia de uma critica ao pluralismo. O pensamento liberal, que fundamenta tanto o pluralismo quanto o corporativismo, orienta-se pela posıço de que, na sociedade civil complexa que caracteriza o mundo moderno, os interesses que se expressam nas arenas políticas não são representados por individuos ou grupos, mas por corporações mais expressivas.

Essas entidades corporativas, criadas pelo próprio Estado ou reconhecidas pelo mesmo, fariam parte de um sistema de intermediação de interesses entre a sociedade civil e o Estado. Os diversos grupos de intermediação, ao serem institucionalizados passam a ser co-responsáveis pelas políticas. Enquanto no pluralismo se pressupõe uma livre competição entre diferentes minorias em busca de consenso intermediado pelo governo, no corporativismo os conflitos não se resolverão pelo consenso. Reconhecese o conflito como "inevitável", em virtude das contradições existentes e propõe-se, não uma competição plural que o solucione, mas um "arranjo político" que constitua um novo contrato entre o Estado e a Sociedade (COUTINHO $^{38} 1989$, p.58; LOBATO ${ }^{61} 1997$, p.34). 


\section{MARXISMO E REPRESENTAÇÃO DE INTERESSES}

A matriz marxista considera que o processo de formulação das políticas públicas pode ser entendido a partir da análise da estrutura econômica de classes e do papel do Estado. Esse pensamento pode apresentar-se a partir de uma posição, habitualmente denominada estrutural-funcionalista, na qual o Estado representaria os interesses da classe dominante ou por outras posições que. considerando a complexificação associada ao papel do Estado, identificam nele a presença de interesses diversos, nem sempre relacionados com os interesses de classes.

Essa renovação do pensamento marxista ocorreu, especialmente, a partir do pensamento de Gramsci, que desenvolveu seus estudos em um contexto de crescimento da sociedade civil, e do reconhecimento da manifestação de múltiplos e complexos interesses na relação entre Estado e sociedade. A interação entre os atores políticos em contronto passa a exigir a busca de relações de consenso para que um desses atores consiga legitimar-se em sua influência necessária para o processo de formulação de políticas. Nessa situação, segundo o pensamento com influência gramsciana, o Estado faz concessões às classes dominadas e permite que seus interesses também possam ser representados nas politicas públicas (COUTINHO $\left.{ }^{37,38}, 1981 ; 1989\right)$.

No âmbito do local, as análises marxistas, no que diz respeito ao sistema de representação de interesses, têm sido feitas com diferentes perspectivas, privilegiando a esfera econômica, a esfera política ou as mediações de poder de classe exercidas pelos atores locais (CASTRO ${ }^{26}$ 1988 , p.57). A separação entre economia e politica, aliás, tornou-se uma das características do Estado moderno. Mais recentemente, inclusive, alguns autores têm-se dedicado a estudar as relações entre Estado, sociedade e 
mercado, pelo fato deste último estar incorporando determinantes novos na análise da realidade social, como decorrência das relações globalizadas.

As diferentes abordagens do local, no pensamento marxista, abrem amplo campo de análise da questão. Apesar de existirem alguns enfoques nessa matriz, tais como o funcionalismo marxista, que consideram o local como sub-produto das contradições gerais da estrutura nacional de classes, reduzindo, como conseqüência, seu alcance e a interferência dos seus atores no processo político local, existem, por outro lado, outros enfoques que apontam para a sua valorização enquanto campo investigativo.

Autores mais próximos do campo funcionalista, como MILLS ${ }^{84}$ (1981) e MILIBAND ${ }^{83}$ (1972), em sua crítica ao pensamento pluralista, que atribui ao espaço local uma distribuição mais democrática de poder, ressaltam que as mesmas relações desiguais de distribuição de poder que se verificam nas Instâncias centralizadas ocorrem nos niveis mais descentralizados.

Entre as diversas vertentes que analisam o local fora do campo funcionalista, percebe-se em alguns, como é o caso daquela defendida por CASTELLS (1981 apud CASTRO $^{26}, 1988$ ), uma valorização do governo local como "o mais penetrável pela sociedade civil e o mais acessivel pelos cidadãos". Esse autor considera que os municipios, apesar de estarem submetidos a determinantes globais de poder, não se constituem em apenas uma replica desse poder. A estrutura de poder local permite a manifestação de interesses "subalternos", das classes populares, porque é o único nivel de governo que pode manifestar interesses contrários à estrutura de poder dominante sem provocar crise nessa estrutura.

A arena política local é sede de alianças e conflitos que estão condicionadas à estrutura do poder local. Os "notáveis locais" utilizam-se, por um lado, do poder que detêm em relação à sociedade local, para atender seus interesses e, por outro, intermediam os interesses locais junto ao 
Estado central, com a finalidade de arbitrar e aliviar os conflitos soriais. Nessa situação, os governos locais deixam somente de representar os interesses dominantes, pois os conflitos decorrentes da implementação das políticas locais ocasionam pressões das populações usuárias sobre esses governos, ao mesmo tempo em que eles sofrem a pressão do Estado central e da falta de recursos, configurando uma situação complexa e contraditória (CASTELLS 1981 apud CASTRO $^{26}$ 1988).

O SISTEMA DE REPRESENTAÇÃO DOS INTERESSES LOCAIS EM UMA REALIDADE SOCIAL COMPLEXA: O MARCO DESTE ESTUDO

É no campo teórico, que conceitua o local como espaço de realidade social complexa, que se situa o marco do nosso estudo. No confronto com os achados empíricos, cuja análise fazemos nos capítulos 4 e 5 , procurou-se considerar os determinantes estruturais de origem central e também a interrelação dos atores com a estrutura de poder local.

Essa análise não foi realizada a partir de um modelo fechado. Diversas publicações têm-se referido à dificuldade de analisar o sistema de representação de interesses dentro do processo politico local a partir de modelos de explicação dogmáticos, que utilizam paradigmas fechados para explicar a realidade social. GERSCHMAN ${ }^{51}$ (1989), por exemplo, afirma a esse respeito: "A questão que se coloca para uma formulação teórica mais acabada das políticas sociais é a integração ao marco metodológico marxista de outros conceitos e aportes teóricos, o que nos permitirá evitar o 'beco sem saída' ao qual nos conduzem o 'pluralismo' e a 'teoria marxista' de cunho estrutural-funcionalista" (p.126).

Referindo-se a esse mesmo assunto, CASTRO ${ }^{26}$ (1988) considera também necessário um "certo grau de pluralismo teórico e tolerância epistemológica, na tentativa de compreender a realidade social" ( $p .56$ ). 
Em nosso entendimento, portanto, a investigação dos interesses que se manifestam na formulação da política e a identificação de sujeitos do processo decisório e de arenas políticas, no contexto da municipalização da saúde, poderão contribuir para melhor análise dos conflitos e alianças que se estabelecem no processo de formulação das políticas locais de saúde.

\subsection{Incongruências da Constituição Federal de 1988 no Brasil}

O texto adotado pela Constituição vigente no Brasil, promulgada em 1988, foi tão favoráve a descentralização que levou SADEK ${ }^{104}$ (1991) a afirmar que "O contraste entre os princípios descentralizadores consagrados pela Constituição de 1988 e os preceitos centralistas do passado é tão profundo que se pode sustentar que estamos face a uma modificação de alcance imprevisivel." (p 9)

Não seria exagero afirmar que na situação anterior à atual Constituição os municipios brasileiros não tinham independência política nem administrativa. Apesar de poderem eleger seus governantes, estavam freqüentemente constrangidos por legislações eleitorais casuísticas, limitaçōes de liberdades partidárias, práticas coronelistas e incentivo a negociações politicas não-institucionais, entre outras restrições ao exercício de sua autonomia política. No campo puramente administrativo nunca houve uma situação que permitisse liberdade na organização dos serviços locais e na elaboração de políticas próprias.

Com a Constituição de 1988, os municípios brasileiros conquistaram, como afirma MEIRELLES ${ }^{78}$ (1990, p.83), uma tríplice autonomia: politica, administrativa e financeira. A autonomia política diz respeito à possibilidade de eleger prefeito, vice-prefeito, vereadores e de legislar sobre assuntos de interesse local. A administrativa possibilitou liberdade para organizar os 
serviços públicos e ordenar o território municipal. E a financeira viabilizou as condições para instituir tributos e aplicar as rendas municipais.

Após a vigência da atual Constituição, o Brasil passou a ser um dos paises de maior descentralização de poder politico e de recursos tributários (SOUZA ${ }^{111}$ 1996, p.103). É necessário, no entanto, relativizar o alcance dessa descentralização, sendo exemplo ilustrativo a alteração na destinação de tributos ocasionada pela Constituição de 1988. Os municipios brasileiros, que no periodo de 1964-1988 detinham 15\% dos recursos nacionais disponiveis, passaram a contar, após 1988, com 22,75\%. Essa elevação, no entanto, sequer coloca o Brasil na condição da maioria dos paises desenvolvidos que, apesar de muitos não considerarem os municipios como entes federados, destinam aos mesmos $30 \%$ da carga tributária nacional (REZENDE ${ }^{101}$ 1998, p.99-100). O Brasil descentralizou o poder de instituir e de arrecadar tributos e ampliou a destinação da carga tributária, porém essa ampliação não foi suficiente para as necessidades e as responsabilidades da instância local.

Além disso, deve-se destacar a enorme diversidade regional do pais e a heterogeneidade de seus municipios. Dos 5.506 municipios brasileiros, cerca de $40 \%$ têm menos de 10.000 habitantes e mais de $50 \%$ não conseguem arrecadar o suficiente para custear as despesas de suas estruturas administrativas e legislativas. Acrescente-se que em 1.965 municipios não são arrecadados impostos federais (MENDES ${ }^{* 2} 1998$, p. 18).

O texto constitucional é explicito quando ressalta a autonomia municipal e os princípios do federalismo, dando liberdade ao municipio de elaborar sua própria Lei Orgânica, legislar sobre assuntos de interesse local e instituir e arrecadar tributos. Essa nova situação, paradoxalmente, não tem sido acompanhada pela independência dos municipios em relação ao governo central. Pelo contrário, o final da década de 1990 caracterizou-se como periodo de crise administrativa de boa parte dos governos locais. 
Existem obstáculos diversos que dificultam 0 alcance dos objetivos propostos na Constituição de 1988.

SOUZA ${ }^{111}$ (1996) assinala alguns aspectos que, segundo ela, explicam essa incongruência entre uma Constituição aparentemente federalista e uma realidade local sem condições de que seja exercida essa autonomia, premida por inúmeras dificuldades. O federalismo, como teoria, segundo a autora citada, implica numa cooperação politica e financeira entre o governo federal e as demais esferas da federação. Apoiando-se em BURGESS (1993 apud SOUZA ${ }^{111}$ 1996, p.104), identifica no federalismo um conceito de valor e uma percepção ideológica que the dão status de ideologia politica. Com base em estudos sobre o federalismo e o que o impulsiona, em diversos paises, identifica diferentes motivações de ordem econômica, politica ou sócio-cultural, que, de acordo com o momento histórico, assumem diferentes formas. No caso brasileiro, o federalismo não teve como principal motivação um pacto político que fosse alavancado por princípios ligados a essa corrente. O fator motivador principal do federalismo brasileiro estava relacionado, como afirma a autora, a "uma forma de acomodação das demandas de elites com objetivos conflitantes, bem como um meio para amortecer as enormes disparidades regionais" (p.104).

No embate entre os centralistas e os federalistas, no período mais imediatamente anterior à Constituição de 1988, o momento político foi favorável ao processo de descentralização. O forte sentimento de oposição à centralização do periodo autoritário pós-1964 até a Nova República, influenciou na descentralização de poder político aos municipios. Esse processo, no entanto, não foi pautado pela reavaliação da relação entre o Estado e a sociedade e por uma tentativa de redefinir o papel do Estado. No campo tributário, por exemplo, alterou-se a estrutura de distribuição da arrecadação tributária, mas as bases de arrecadação foram mantidas intactas e a regressividade dos impostos não foi alterada. 
A autonomia administrativa local está claramente tolhida por determinantes econômico-estruturais, apesar da maior liberdade, formal, que passou a ter em relação ao governo central. Os recursos acabam sendo insuficientes para cumprir com as responsabilidades que teve de assumir. $E$, como disse DOWBOR ${ }^{39}$ (1998, p.11), "quando os processos de decisão não são acompanhados dos fluxos financeiros, a máquina emperra".

No contexto de recursos financeiros insuficientes e de responsabilidades crescentes dos governos locais, os governantes locais não só eles mais também os dos outros niveis de governo - passaram a ser mais rigidamente fiscalizados. A publicação da Lei Complementar $N{ }^{\circ} 101$ de 04 de maio de 2000 (BRASIL ${ }^{14}, 2000$ ), que ficou conhecida como Lei de Responsabilidade Fiscal (LRF), estabeleceu metas para gastos públicos nos três níveis de governo e tornou mais rígida a fiscalização e a responsabilização dos governantes com a gestão fiscal. Os governantes que não obedecerem os limites de gastos e de negociação da dívida publica passaram a ter punição prevista no Código Penal por crime contra as finanças públicas, com penas de reclusão da liberdade, que variam conforme a falta cometida. A LRF representa, em nosso ponto de vista, um instrumento de ajuste necessário para que os governantes não gastem mais do que podem gastar e não deixem dividas para seus sucessores, comprometendo as administrações futuras. Surge, no entanto, em um contexto de responsabilização crescente dos governos locais para o atendimento às demandas sociais em geral, e da saúde em particular. Apesar de benéfica para conter o impeto de administradores perdulários e inconseqüentes, representa também, em uma situação de falta de recursos e de endividamento da maioria dos municípios, restrição do atendimento a essas demandas.

Por outro lado, apesar dos constrangimentos financeiros a que estão submetidos os governos locais e da maior fiscalização sobre os governantes, a situação atual também caracteriza-se por um momento mais 
favorável à democratização do espaço local. A legislação prejê a participação da população na gestão da coisa pública e dá maior possibilidade de intervenção aos grupos de interesse local. É nessa perspectiva que será tratado o tema do item que se segue.

\subsection{A participação da sociedade na política}

CHIRINOS (1991 apud TEIXEIRA'120 1998, p.29) define seis tipos de participação política: (1) eleitoral ou partidária; (2) dos movimentos sociais; (3) de ação comunitária; (4) manipulada por governos; (5) de controle dos recursos e instituições estatais e (6) das estruturas governamentais de decisão. Constitui objetivo de nosso estudo focalizar um aspecto particular da participação: o que diz respeito à sua relação com o processo decisório local.

A participação enquanto fenômeno de manifestação coletiva tem inúmeros significados e pode ser tratada das mais variadas formas, em virtude da complexidade de fatores com as quais se relaciona. Os diferentes tipos de participação e as diferentes dimensões que a mesma pode assumir - direta ou indireta; institucionalizada nas instâncias formais do Estado ou dentro de movimentos da sociedade; e objetivando apenas exprimir-se ou influir de fato nas decisões que estão sendo tomadas - tem em comum o sentimento, e o desejo de fazer parte do processo coletivo em questão.

Nem sempre essa vontade de influir, de tomar parte e de aproximar o social do político está presente. Muitas vezes, mesmo em ambiente sem constrangimentos legais, democrático, o sentimento predominante é o da apatia, do afastamento. Para que haja participação, há a necessidade de motivação e esta depende de diversos fatores, entre os quais o contexto sócio-político e histórico do país. 
Ao longo de nossa história, no Brasil, houve diversos fatores que motivaram a participação da população. Ocorreram momentos, como na década de 1970, após a ruptura institucional de 1964 que deu origem ao período burocrático-autoritário, em que o governo estimulava a sociedade a participar, visando obter apoio às suas ações de governo. Os governantes instituiram campanhas como "Ouro para o bem do Brasil" e "Brasil: ame-o ou deixe-o" procurando, em um periodo de censura dos meios de comunicação, induzir a sociedade a apoia-los. Era uma participação tutelada e administrada pelo Estado. De acordo com a classificação exposta no início deste tópico, trata-se de participação "manipulada pelo governo". Em outros momentos, o estímulo estava na própria sociedade, tal como ocorreu no período de abertura politica, em que o motivo para a participação passou a ser o enfrentamento ao Estado autoritário, exigindo democratização, "diretas já", anistia politica etc. (CARVALHO ${ }^{22}, 1994$; TEIXEIRA' ${ }^{120}, 1998$ ).

Com o fim do período autoritário e a instauração do pluralismo politico, em decorrência do advento da "Nova República", a participação deixa de ter como foco a luta contra o Estado. Entra na agenda de diversos movimentos sociais a preocupação com a democratização. O campo de luta não está mais localizado, necessariamente, fora do âmbito do Estado, mas também dentro do seu próprio aparelho. O "Estado plural" do fim do autoritarismo passa a ser compativel com a manifestação de distintos interesses. O processo político passa a ter a participação de atores políticos diversos, inclusive populares, na formulação e implementação das politicas públicas.

Não estamos querendo dizer que a democratização do Estado ocorreu por completo e que o interesse das maiorias já esteja prevalecendo nas ações do Estado; ou ainda, que a interferência dos atores populares já tenha se tornado decisiva. Apenas nos estamos referindo, com base nos autores citados, que o processo político passa a admitir a diversidade de 
interesses. As diferentes concepções acerca de como esses interesses se podem manifestar, foram expostos em tópicos precedentes, neste capítulo.

A interferência dos atores populares no processo decisório está diretamente relacionada com a existência de regras democráticas e, segundo alguns autores, com o estímulo à participação e à credibilidade conquistada pelo processo. Como afirma TEIXEIRA ${ }^{120}$ (1998, p.32), não se trata de o Estado "conceder" a participação, mas mostrar-se aberto ao diálogo, condição esta que se pode colocar até como alvo da própria participação; ou seja, a abertura, a transparência e a honestıdade do Estado podem ser a primeira etapa a ser atingida como decorrênca da participação política. Sem essa transparência e um mínimo de regras e compromissos nas arenas políticas, a participação dos diferentes atores fica bastante dificultada.

A participação mais ampla nas decisões de governo transformou-se em bandeira dos setores sociais mais progressistas, com a Constituição de 1988. A estratégia para a ampliação dessa participação, por parte desses setores, tem sido construída com o objetivo de institucionalizar formas de democracia direta no processo político.

$\mathrm{BOBBIO}^{4}$ (1983), referência obrigatória no estudo desse tema, ao analisar as formas representativas e diretas de participação, refere-se ao fetiche que a democracia direta causa, especialmente no pensamento da esquerda socialista. Para Bobbio, quando se fala em democracia direta, habitualmente se pensa em referunduns nos quais a população em geral possa exprimir-se e influir em temas de interesse nacional ou local. É preciso analisar, no entanto, segundo esse autor, até que ponto esse tipo de manifestação é possível, tem viabilidade operacional, e quais são suas relações com a democracia indireta. Questionando essa viabilidade, propõe ele uma integração entre as duas formas de democracia, direta e indireta, 
considerando que uma não pode substituir a outra e as duas, juntas, nãu são incompatíveis (p. 68-69).

A democracia de Rousseau, que preconiza grandes assembléias, com a participação de todos os cidadãos, não está, segundo Bobbio, suficientemente precisa em suas particularidades técnicas, e poderia até ser possivel para pequenos agrupamentos, mas seria evidentemente impossivel de ser aplicada numa sociedade complexa como a atual. ROSSEAU ${ }^{102}$, em o Contrato Social, deixa claro que sua concepção de "verdadeira democracia", no sentido rigoroso do termo, nunca existiu nem jamais existirá; a propósito, a esse respeito, afirma: "Se exisisse um povo de deuses, governar-se-ia democraticamente. Um governo tåo perfeito, não convém aos homens" (p.69).

É dificil estabelecer um consenso sobre o que sejam regras democráticas. Quando se fala de democracia direta, no sentido rousseauniano do termo, habitualmente se desconsidera a natureza do Estado. A teoria socialista de Estado. por outro lado, refere-se à democracia direta de forma totalmente distinta, colocando essa questão como ligada às relações entre as classes sociais e o papel do Estado e, classicamente, trabalha com conceitos de "democracia burguesa" e "democracia socialista" $\left(\mathrm{SAES}^{105}, 1987\right)$.

De acordo com BOBBIO (apud FLEURY ${ }^{48}$ 1997, p.29), a democracia contêm dois sentidos básicos: o formal e o substancial. No primeiro, a evidência maior é sobre o conjunto de regras que devem existir para que o jogo político se estabeleça; em seu sentido substancial, prevalece a concepção ideal de democracia, em que o valor mais importante a ser considerado é o da igualdade entre os cidadãos.

Neste estudo, vamos considerar que o Brasil esteja avançando, apesar de muito longe do desejável, em um dos sentidos da democracia, no 
seu sentido formal, segundo a acepção de Bobbio. Para esse autor, a democracia, formalmente, significa respeito às regras existentes. Essa condição é indispensável para que os diferentes interesses se manifestem.

Pode-se considerar, por outro lado, que o Brasil se encontra muito distante da democracia no seu sentido substancial, de igualdade, tanto na dimensāo de direitos quanto na dimensão econômica. Torna-se desnecessário reafirmar a grande desigualdade existente em nosso pais, no campo dos direitos humanos, sociais e da distribuição de renda.

Além das condições formais, traduzidas pela permeabilidade das estruturas de poder para o processo de participação, é necessário existir também o que alguns autores denominam cultura politica ancorada em valores de solidariedade, para que assumam caráter político e transformador (TEIXEIRA ${ }^{120}$, 1998). Ou seja, a vontade de "fazer parte" do processo decisorio deve estar ancorada em valores relacionados às questões gerais da sociedade, e de interesse geral, para que não prevaleçam interesses particulares ou corporativos, e para que os agentes interessados não sejam mais facilmente envolvidos "na lógica própria do poder, na racionalidade técnico-burocrática" (p.35)

\section{PARTICIPAÇÃO CIDADÃ, COMUNITÁRIA E POPULAR}

Essa concepção de participação moldada por principios de solidariedade social tem sido tratada na literatura sob a denominação de participação cidadã. O último autor citado, Teixeira, define participação cidadã como "um processo complexo e contraditório da relação entre sociedade civil, Estado e mercado, em que os papéis se redefinem pelo fortalecimento da sociedade civil através da associação organizada dos inaividuos, grupos e associações" (p.35).

Esse tipo de participação não se define como simplesmente apoiando ou lutando contra o Estado, mas incorporando uma concepção de Estado 
que contém interesses contraditórios, constituindo direito de todos os cidadãos e segmentos sociais buscar formas de se fazer representar no interior do aparelho estatal, procurando legitimar seus interesses.

É necessário diferenciar a participação cidadã de outras formas, como a "comunitária" ou a "popular", que se constituem em expressões de outros significados. Essas duas formas de participação estão mais relacionadas com a prestação de serviços à comunidade, mutirões, parcerias ou com ações reivindicativas e de protesto. O campo de atuação da participação cidadã, apesar de se diferenciar destas, nem sempre, porém, é totalmente claro. Preferimos enquadrá-la, aderindo à opção de alguns autores, em um campo mais institucionalizado de ação, onde a busca do exercício da cidadania se dá em canais que pertencem ao arcabouço jurídico-institucional do Estado, ou a partir de mecanismos e canais presentes no interior da sociedade. O foco de atenção da participação cidadã, esteja ela sendo exercida na sociedade, no mercado ou no interior do aparelho estatal, pode estar tanto no Estado quanto na própria sociedade (CARVALHO ${ }^{23}$ 1997; TEIXEIRA $\left.{ }^{120}, 1998\right)$.

\section{CONTROLE SOCIAL}

A forma pela qual a sociedade procura exercer sua cidadania constitui modalidade própria de regulação, que pode ser entendida como controle social. Este, de acordo com TEIXEIRA ${ }^{120}$ (1998 p.48) tem duas dimensões básicas: a accountability e a responsabilização dos agentes políticos pelos atos praticados em nome da sociedade.

Accountability, de acordo com $\operatorname{BITTAR}^{3}$ (1997, p.82), é um conceito dificil de ser definido, mas pode entender-se como "relacionado com a responsabilidade social pelo desempenho de tarefas, democracia, respeito pelo cidadão". O controle social implica, portanto, em submeter o poder dos agentes políticos à regulação da sociedade, corrigindo eventuais desvios e 
responsabilizando aqueles que se utilizaram indevidamente do poder que Ihes foi outorgado pela sociedade.

O controle social e a participação cidadã confundem-se, porque ambos procuram conquistar direitos sociais e partilham dos mesmos valores. A participação cidadã, no entanto, está centrada na busca da eqüidade social, da universalização dos direitos, na solidariedade. Seus objetivos estão ligados à construçāo de uma democracia mais substantiva, de igualdade, de conquistas. O controle social, por outro lado, constitui-se em mecanismo de vigilàncıa de agentes e instituições políticas que atuam nas estruturas de poder. Se radicionalmente, conforme afirma VIEIRA ${ }^{127}$ (1999, p.252), o controle social era "visto como o aumento da capacidade de influência da sociedade sobre o Estado", hoje "passa a ter duplo caráter: aperfeiçoar os mecanısmos de controle da sociedade sobre o Estado e inventar formas de controle da sociedade sobre a sociedade".

Nem sempre, porem, foi esse o entendimento de controle social. Há algumas décadas o alvo do controle da sociedade era o indivíduo e não o Estado ou a própria sociedade. A meta era a limitação do agir individual, enquadrando-o em determinados padrões de comportamento culturalmente estabelecidos. Essa inversão de concepção de controle social, passando a ter como foco não os individuos, mas as diferentes estruturas de poder, com o objetivo de assegurar os direitos coletivos e individuais, trouxe novo entendimento a respeito de controle social, participação e cidadania. Os efeitos da globalização e da comunicação, a partir da década de 1990, têm, segundo alguns autores, modificado a forma pela qual se têm exercido a vigilância e o controle nas sociedades modernas.

HOBSBAWN $^{54}$ (1999) refere-se à desconsideração da maioria da população quanto ao processo político tradicional, como uma das características do final do século $X X$. Está havendo desinteresse cada vez maior em relação à política e às instituições do Estado. Esse desinteresse 
coletivo não significa, segundo esse autor, uma ausência de participação nas questões políticas. O que essa reflexão traz de relevante, e parece-nos que, apesar de estar colocada em um contexto de análise que leva em conta o que ocorre nos países industrializados, também se aplica a países em outros estágios de desenvolvimento, tais como o Brasil, é a mudança na forma de influência que a sociedade está passando a exercer sobre o processo político.

Paralelamente ao descrédito dos partidos politicos e das instituições de Estado, está havendo uma ampliação da função polıtica dos meios de comunicação. O extraordinário crescimento do poder dos meios de comunicação, que chegam a praticamente todas as casas e pessoas, os tornam um ator de grande capacidade de influência, muito difícil de ser totalmente monopolizado ou manipulado nos Estados modernos nãoautoritários.

Afirma HOBSBAWN" (1999) que "quando o século acabava, tornouse evidente que os meios de comunicação eram um componente mais importante do processo político que os partidos e os sistemas eleitorais, e provavelmente assim continuariam - a menos que os politicos dessem uma forte guinada para longe da democracia" (p.559). A identificação coletiva, quando ocorre, diz esse autor, se faz muito mais em esportes ou grandes fatos de comoção e emoção nacional e simbolos não-políticos, do que relacionada com as instituições de Estado. E as manifestações de interesse conduzidas por minorias, em cima de objetivos especificos, interferem mais no processo político do que se o fizessem a partir de partidos políticos, porque conseguem convergir sua energia para esses objetivos.

\section{CCNSELHOS POPULARES, PARITÁRIOS E GESTORES}

Para os propósitos deste estudo nos interessa aprofundar a análise das formas de participação política e de controle social que têm como alvo as estruturas decisórias que se situam no âmbito dos governos locais. Além 
dos mecanismos formais de participação, próprios da democracia representativa, tais como o processo eleitoral para a Câmara de Vereadores e para o Executivo Municipal, outros instrumentos têm sido utilizados, como conselhos populares e setoriais (saúde, educação, ação social etc.). Esta última forma de participação pressupõe que para o processo democrático não bastam as previstas na democracia representativa. Esse processo não pode prescindir de formas de participação direta da sociedade nas decisões de governo.

A origem dos conselhos populares no Brasil é analisada por WANDERLEY ${ }^{128}$ (1991, p.27), que se refere à relação entre a utilização de conselhos como forma de organização de trabalhadores e operários e os setores da esquerda socialista e comunista, especialmente após a notoriedade que ganharam os sovietes e os conselhos de fábrica na experiência revolucionária da URSS. O papel dos conselhos em regimes não-socialistas suscitou grandes controvérsias, porém constituíram experiências inovadoras tanto na esfera do movimento sindical quanto na atuação de partidos de esquerda e social-democratas, tendo possibilitado avanços aos trabalhadores. Segundo esse autor, os principais avanços ocorreram no campo do controle social, da descentralização do poder e do exercicio do poder local.

No Brasil, ainda segundo o autor acima citado, duas situações distintas marcam o surgimento dos conselhos: o movimento das oposições sindicais nas décadas de 1970 e 1980, em São Paulo, que instituiu as comissões de fábrica como proposta de organização dos trabalhadores nas bases, e os conselhos populares de administrações municipais democráticopopulares do Partido dos Trabalhadores, no final da década de 1980 (MOISES $^{88}$ 1986, p. 19).

As comissões de fábrica enfrentaram dificuldades diversas, entre as quais a resistência dos empresários e de lideranças sindicais tradicionais. 
Além disso, foi dificil a integração entre a lógica do movimento sindicai e a necessária autonomia das comissões.

Os conselhos das administrações democrático-populares, à época, eram considerados com base em três diferentes concepções ideológicas: (1) sua constituição é prerrogativa do partido e da administração petista; (2) é uma proposta de democracia direta que pretende contribuir para uma mudança social não-burguesa, e (3) constituem-se em instrumentos de democratização do Estado a partir da transparência e da contribuição na viabilização de políticas públicas voltadas para os interesses populares. Esta última posição, majoritária dentro do partido e das administrações, acabou por prevalecer. Os conselhos, nessas administrações, passaram a ser considerados canais de participação e democratização, cujos limites se encontravam estabelecidos pela legislação vigente e pela institucionalidade do país. Os conselhos populares passaram a fazer parte das administrações do PT, tanto em governos municipais, (sendo a administração de Porto Alegre o exemplo mais paradigmático) quanto, mais recentemente, em administrações estaduais

A questão dos conselhos populares, porém, ainda constitui objeto freqüente de conflitos político-ideológicos. Apesar da posição majoritária que atribui aos conselhos o papel de reforço à democratização, incorporando atores populares ao processo decisório tradicional, eles são também considerados como ferramenta para o acúmulo de forças politicas e de poder alternativo. Neste último campo, diferentes graus de autonomia são atribuidos aos conselhos. As tendências que pregam uma autonomia mais radical, procuram negar o jogo político tradicional e correm o risco de isolamento politico. Outras, menos radicais, atuam tanto dentro do jogo político quanto na defesa da autonomia, construindo nessa dualidade sua estratégia (WANDERLEY ${ }^{128} 1991$, p. 29). 
Tanto as experiências das comissões de fábrica quanto a dos conselhos populares petistas, nos seus primórdios, constituíram experiências fora do campo da institucionalidade do Estado. Na década de 1980, com o alargamento político dos espaços de participação do Estado, passaram a surgir alternativas que possibilitaram a segmentos da sociedade civil se fazerem representar em seus mecanismos formais de poder. Os conselhos setoriais de saúde e assistência social, entre outros, como componentes do arcabouço jurídico-institucional do Estado, surgem em um contexto de disseminação de uma concepção pluralista do poder estatal. Conforme afirma CARVALHO ${ }^{23}$ (1997, p.96), a ampliação da participação política com o advento da Nova República, em meados da década de 1980, e o reconhecimento, por parte do Estado, de que as politicas públicas devam ser "fruto do processo de disputa e pactuação entre grupos de interesse no seu interior", aumentam as formas de representação direta da sociedade.

A descentralização das politicas sociais, e em especial a da saúde, analisada no capítulo 1, foi acompanhada pela criação de conse/hos paritários de representação, compostos de usuários, entidades da sociedade civil, entre as quais prestadores de serviço público, e representantes do governo. Os conselhos paritários diferenciavam-se dos populares porque nestes costuma haver predominância absoluta de segmentos populares.

Além da composição, outra diferença relevante entre esses dois tipos de conselhos é constituída pelo fato de que os conselhos de composição paritária, como os conselhos de saúde, por exemplo, surgem por iniciativa do Estado e passam a ser componentes do aparelho estatal. Os conselhos populares, por outro lado, surgem externos ao Estado e, mesmo se tendo institucionalizado em algumas administrações populares, não costumam fazer parte da institucionalidade do Estado, constituindo canal mais "marginal" de poder. 
O processo de municipalização da saúde ampliou o número de conselhos de saúde no pais, conforme analisamos no capitulo $1, \mathrm{e}$, em muitos municípios criou também conselhos de usuários, também denominados conselhos locais de saúde ou conselhos gestores de unidades de saúde, que habitualmente não obedecem o critério de paridade, tendo maioria de usuários.

Existem diferentes visões sobre o significado dessa mudança de postura do Estado brasileiro, ao dar institucionalidade aos mecanismos de participação direta no âmbito das políticas sociais, através dos conselhos. Seus aspectos mais relevantes dizem respeito, por um lado, aos avanços obtidos na luta pela redemocratização do Estado e, por outro, pelos próprios interesses do capitalismo em seu processo de legitimação política.

WANDERLEY $^{128}$ (1991, p. 25) situa com clareza os três diferentes posicionamentos que se verificam na análise do alcance dessa forma de participação: os otimistas admitem modificações estruturais na "refundação do Estado, pelo influxo da crescente participação democratizadora em todas as relações sociais"; os negativistas sustentam que essas formas de participação não tem interferido nas grandes decisões políticas; os intermediários, que relativizam o alcance e ressaltam influências reciprocas entre as duas partes - movimentos populares e governo. 


\section{CAPÍTULO 3}

\section{ASPECTOS METODOLÓGICOS}

Para a elaboração do projeto de pesquisa foi adotada a orientação de alguns autores (TRIVIÑOS ${ }^{124}$ 1987; QUIVY e CAMPENHOUDT ${ }^{100}$ 1992; MINAYO ${ }^{85}$ 1989; CONTRANDRIOPOULOS e col ${ }^{36} 1997$ ), que propõem a utilização de um fio condutor para nortear o processo de investigação. Este, em nosso estudo, foi construído a partir das seguintes questões:

- O processo de descentralização da saúde no Brasil está ocasionando deslocamento de poder para os municípios?

- Qual é o alcance e quais são as limitações desse deslocamento de poder?

- Como se realiza o processo decisório local no âmbito das políticas de saúde do subsistema público?

- Quais são os fatores que favorecem ou dificultam a implementação de modelos de saúde alternativos ao modelo assistencial-privatista hegemônico, no âmbito local?

No desenvolvimento do projeto, concluímos que nosso propósito de tentar responder essas questões permitia definir como nosso objeto de estudo a análise sobre o processo de decisão das politicas locais de saúde no contexto da municipalização da saúde. A finalidade deste capítulo é explicar como se estabeleceu a metodologia para a realização do estudo.

De acordo com MINAYO ${ }^{87}$ (1999, p.22), a metodologia deve incluir: (1) as concepções teóricas que fundamentam a análise; (2) as técnicas ou conjunto de técnicas utilizadas para compreender a realidade e (3) o 
potencial criativo do pesquisador.

O terceiro item refere-se, em especial, ao tratamento dado ao confronto entre a teoria que fundamenta a pesquisa e os dados empíricos. Os três componentes da metodologia - teoria, técnica e criatividade - devem estar articulados numa lógica metodológica consistente, não sendo conveniente o predominio de um dos componentes para evitar a teorização excessiva, a supervalorização da técnica ou o empirismo irracional. Com o objetivo de atender esses requisitos, utilizamos a proposta de MINAYO ${ }^{87}$ (1999) e de outros autores citados ao longo deste capítulo, como guia para a definição metodologica do estudo.

O desenvolvimento do capitulo se dará em duas partes: fundamentação teórica e (2) aspectos metodológicos do estudo empírico. Para a segunda parte, três tópicos serão desenvolvidos: 1. particularidades do estudo de caso; 2 hipóteses ou pressupostos, e 3. categorias empíricas.

\subsection{Fundamentação teórica}

A teoria está sempre presente em uma pesquisa. Autores como TRIVIÑOS $^{124}$ (1987), QUIVY E CAMPENHOUDT ${ }^{100}$ (1992) e MINAYO ${ }^{87}$ (1999), entre outros, nos ensinam que o modo pelo qual o investigador considera a questão da pesquisa e formula os problemas que quer desvendar, o identifica com o enfoque teórico que pessoalmente utiliza para interpretar a realidade. A simples escolha de um objeto de estudo e a opção de como investigá-lo tem relação com determinada compreensão da realidade e é, conseqüentemente, sustentada por determinado arcabouço teórico. Essa premissa evidencia, segundo esses autores, que nenhuma pesquisa é neutra, por mais simples que seja e por menos organização lógica que tenha. Ela expressa uma forma de pensar e indica, consciente ou 
inconscientemente, a corrente de pensamento que o pesquisador utiliza para conduzi-la.

Na elaboração do projeto, adotamos as questōes iniciais, referidas no início deste capítulo, como o fio condutor da investigação. Essas questões contribuíram para delimitar a área de interesse do estudo, que foi submetida a uma análise exploratória - através da literatura e de entrevistas com pesquisadores do tema - que subsidiou a elaboração do projeto. Foram destacados conceitos que tiveram interesse para o estudo: governos locais, poder local, sistemas de decisão e participação politica, arenas políticas e decisórias etc. Diversos autores, citados nos capitulos 1 e 2, contribuiram para o aprofundamento teórico desses diferentes assuntos. Procurou-se articular os diversos conceitos envolvidos com essas questões em duas categorias de análise principais: a municipalização da saúde e o poder local. Essas duas categorias foram desenvolvidas, respectivamente, nos capítulos 1 e 2 .

No nosso entendimento a abordagem dialética, adotada neste estudo, é a mais adequada para apreender a realidade à qual estão associadas essas duas categorias de análise. Não se pretendeu, no entanto, utilizar de forma hermética, ou fechada apenas um paradigma para analisar o objeto de estudo. Como afirma CARVALHO ${ }^{43}$ (1995), a análise da realidade social deve procurar uma intercomunicação entre diferentes perspectivas teóricas. Entendemos que podem ser utilizadas essas diferentes perspectivas, desde que a lógica metodológica da pesquisa preserve a necessária coerência na correlação entre a teoria e a técnica utilizada.

A opção pela abordagem metodológica dialética deveu-se também ao fato de, como diz MINAYO ${ }^{85}$ (1989), ser a única que consegue fazer o questionamento do sentido das ações. Essa autora refere-se à importância das explicações estruturais, funcionais, fenomenológicas etc. que podem ser utilizadas, desde que submetidas "às representações fundamentais que o 
método dialético supõe da realidade" (CARDOSO apud MINAYO ${ }^{85} 1989$, p.119).

Decidimos realizar análise qualitativa dos dados empíricos, aplicando a proposta hermenêutico-dialética difundida por MINAYO $^{87}$ (1999, p. 218228). Antes de discorrer sobre essa proposta, consideramos importante apontar alguns aspectos do debate que se tem travado sobre as metodologias qualitativas e quantitativas e sua aplicação no campo da pesquisa social, como sugerem CASTRO e BRONFMAN (1997), já que neste estudo, por vezes, utilizamos os dados obtidos de forma quantitativa.

Um dos pontos centrais desse debate refere-se à necessidade de superação da dicotomia entre quantitativo e qualitativo na estratégia de pesquisa. Como afirma SPINK ${ }^{113}(1997$, p.2), a oposição entre esses dois métodos - quantitativo e qualitativo - "tem pouco a ver com as técnicas e análıse dos dados. Desenha-se no interior de outra questão que lhe é anterior - a natureza do fazer científico - sendo aí o discurso hegemônico o da 'retórica da verdade' articulada, no dizer de Tomas Ibañez (1991), pela razão científica e pelos critérios aí utilizados para a legitimação das descrições e explicações". Ou seja, a escolha do método quantitativo ou do qualitativo para analisar os dados empíricos não é o mais relevante. O que importa é o enfoque teórico da pesquisa e a sua concepção sobre a busca do conhecimento e da verdade científica. O investigador pode incluir em sua estratégia instrumentos de análise quantitativos ou qualitativos, e mesmo sua integração, desde que a lógica metodológica tenha consistência e coerência com o enfoque teórico proposto e esteja bem elaborada em seus aspectos operacionais.

No Brasil, discussão a respeito do quantitativo/qualitativo no campo da pesquisa em saúde, coordenada por MINAYO e SANCHES $^{86}$ (1993), tendo como objetivo apontar as potencialidades e limitações dessas alternativas, levou às seguintes conclusões: (1) as investigações quantitativa 
e qualitativa são de naturezas diferentes: a primeira atua em um plano da realidade em que os dados se apresentam aos sentidos, e a segunda trabalha com valores, crenças, representações, hábitos, atitudes e opiniões; (2) nenhuma das duas opções é mais cientifica que a outra: a pesquisa quantitativa, mesmo manipulando sofisticados instrumentos de análise pode vir a desconhecer "aspectos importantes dos fenômenos ou processos sociais estudados", enquanto a pesquisa qualitativa "em si não garante a compreensão em profundidade"; (3) a análise das relações sociais deve ser feita considerando seus aspectos mais concretos, aprofundando-se também em seus aspectos mais essenciais. Não existe, portanto, "oposição contraditória" entre os dois métodos, pois "o estudo quantitativo pode gerar questōes para serem aprofundadas qualitatıvamente e vice-versa".

Na estratégia de pesquisa utilizada neste estudo foi adotada postura pragmática, tendo em conta que não há "oposição contraditória" entre os métodos quantitativo e qualitativo, conforme proposto por esses últimos autores. Como os dados $\mathrm{e}$ informações tiveram origem basicamente em documentos e entrevistas, eles foram, em algumas situações, quantificados, mas sempre submetidos à análise qualitativa.

\subsubsection{Proposta hermenêutico-dialética}

A Hermenêutica, afirma Minayo - apoiada nos debates entre Gadamer e Habermas - tem os seguintes pressupostos metodológicos: (1) o pesquisador deve ter clara, para si próprio, a importância do contexto dos entrevistados e do material que está sendo analisado; (2) esse material tem sempre algum teor de racionalidade, mesmo que, à primeira vista, isso possa parecer absurdo; (3) as "razões" dos autores que contribuiram para elaborar os textos devem ser levadas em conta; (4) os textos devem ser entendidos e interpretados sob dois pontos de vista: o do autor do texto e o do investigador, e (5) a interpretação do investigador, se bem sucedida, é de 
se supor que poderia ser compartilhada pelo autor, caso pudesse fazê-lo segundo a racionalidade do investigador.

A aplicação da Hermenêutica na interpretação dos dados tem como finalidade compreender os valores do sujeito da fala, suas razões e, em conseqüência, seus significados. Conforme afirma MINAYO ${ }^{87}$ (1999, p.223), a Hermenêutica "repudia o objetivismo que estabelece conexão ingênua entre os enunciados teóricos (...) dados fatuais (...) e o idealismo filosófico que coloca a verdade nalgum lugar fora da práxis".

A Dialética e sua aplicação ao método hermenêutico-dialético, segundo Minayo, apresenta alguns elementos de destaque: (1) a razão humana permite que se compreenda a realidade $e$, na sua capacidade de critica, esclarece, reúne, contesta e dissocia; (2) a totalidade do mundo real é composta de trabalho, poder e linguagem. Os significados da linguagem dizem respeito, portanto, a apenas um dos fatores dessa totalidade; (3) o método deve buscar uma interpretação que leve à transformação e viceversa, devendo-se reconhecer a existência do engajamento em todo trabalho de compreensão, e (4) o pensamento está condicionado historicamente e o discurso e a imagem lingüistica do mundo se estruturam sobre determinismos histórico-sociais - modo de produção, relações sociais de produção etc.

Referindo-se à Dialética e Hermenêutica, STEIN ${ }^{115}$ (1987 p.98) situa a primeira como ligada ao método de apreensão da verdade e à segunda como "tentativa de inventar a verdade mesmo para além do método". Segundo esse autor, esses dois caminhos - Dialética e Hermenêutica representam a busca de instrumentos de racionalidade que fundamentem a verdade, por intermédio da confluência entre a filosofia e as ciências humanas. 
Além de reconhecer a possibilidade de quantificação dos dados, quando necessário, a proposta hermenêutico-dialética reconhece também a possibilidade de utilização de instrumentos próprios da metodologia qualitativa tradicional, tais como a análise de conteúdo e a análise de discurso. Segundo Minayo, esses instrumentos de pesquisa podem também ser utilizados como auxiliares para a operacionalização da proposta hermenêutico-dialética.

Segundo BARDIN" (1995, p.9), análise de conteúdo é "um conjunto de instrumentos metodológicos cada vez mais subtis em constante aperfeiçoamento, que se aplicam a 'discursos' (conteúdos e continentes) extremamente diversificados. O fator comum destas técnicas múltiplas e multiplicadas - desde o cálculo de freqüência que fornece dados cifrados, até a extração de estruturas traduziveis em modelos - é uma hermenêutica controlada, baseada na dedução: a inferência".

A análise de conteúdo tem um campo amplo de aplicação, podendo ser adotado em grande variedade de situações. Pode ser utilizada para analisar desde conteúdos subjacentes a um manual escolar ou à tipologia de anúncios matrimoniais, até ao estereótipo dos papéis da mulher na sociedade ou a estruturas narrativas de histórias humorísticas. Para isso vale-se de um conjunto de regras e técnicas que pretendem captar informações objetivas, as quais thes permitam inferir significados nos documentos ou nas entrevistas realizadas.

A análise de discurso, criada pelo filósofo francês Michel Pêcheux na década de 1960, como diz MINAYO ${ }^{87}$ (1999, p.211), situa-se entre as Ciências Sociais e a lingüistica, e tem dois pressupostos básicos:

1. O sentido de uma palavra, de uma expressão ou de uma proposição não existe em si mesmo, mas expressa posições ideológicas em jogo 
no processo sócio-histórico no qual as palavras, as expressões e proposições são produzidas.

2. Toda formação discursiva dissimula (pela transparência do sentido que nela se constitui) sua dependência das formações ideológicas (Pêcheux:1988, 160-162).

As aplicações metodológicas da análise de discurso são diversas e, de acordo com SIMIONI ${ }^{1 *}$ e col. (1996), podem-se utilizar quatro figuras metodológicas: a ancoragem; a idéia central; as expressōes-chave e o discurso do sujeito coletivo. A análise dos dados, utilizando essas figuras, permite identificar os pressupostos teóricos - conceitos, ideologias etc. - do autor do discurso, apreender a síntese do conteúdo discursivo explicitado pelos sujeitos e clarear as representações sociais dos sujeitos coletivos envolvidos.

A proposta hermenêutico-dialética diferencia-se da análise de conteúdo e da análise de discurso, segundo Minayo, porque enquanto estas constituem uma tecnologia de interpretação dos textos, a proposta hermenêutico-dialética institui "um caminho do pensamento". Essa autora não nega, no entanto, sua utilização como instrumento complementar na análise dos dados, como foi referido acima.

\subsubsection{Aspectos teóricos de análise de politicas públicas}

O objeto deste estudo trata das políticas locais de saúde, no contexto da municipalização. De acordo com MAINGON ${ }^{66}(1992$, p.8), na análise de uma politica pública é necessário identificar como os diferentes atores sociais e institucionais interagem, formulam seus problemas e buscam solucioná-los, e de como se dá a negociação entre as forças sociais e políticas envolvidas. 
Algumas dificuldades devem ser superadas nessa análise. Uma delas consiste em estabelecer o significado do termo política, cujo conceito é controvertido, pois pode assumir diferentes acepções no campo das várias disciplinas do conhecimento e como decorrência da racionalidade de quem o utiliza. Isso determina que o conceito de "política" seja apropriado de diferentes formas por economistas, cientistas sociais, empresários e políticos, entre outros, os quais o utilizam ao se referir a politica empresarial, política econômica, política institucional, politica organizacional etc.

Neste estudo, a palavra politica è uthrado conforme o conceito proposto por SALAZAR-VARGAS ${ }^{106}$ (1995, p 17) como termo derivado do inglês policy (ou policies, no plural), que significa "diretriz ou curso definido de ação, deliberadamente adotado e perseguido para atingir um determinado objetivo".

Também controvertido é o conceito de politica pública. SALAZARVARGAS $^{106}$ (1995) considera que quando essas diretrizes ou cursos de ação são desenvolvidos por algum ministério ou organısmo do governo, fala-se em "políticas públicas". Estas, da mesma forma como ocorre para o termo "política", têm várias definições. O autor propōe para políticas públicas a seguinte definição: "o conjunto de sucessivas respostas do Estado frente a situações consideradas socialmente como problemáticas".

Independentemente do conceito que se adote para políticas públicas é importante que se considere que elas dizem respeito ao processo que se relaciona com a tomada de decisões por parte do Estado. Essas decisões são dirigidas a toda a sociedade, que deve, obrigatoriamente, acatar o que foi decidido. Ou seja, as autoridades políticas, por intermédio do uso do pocer de que dispõem, conseguem que as decisões sejam acatadas como valores que atingem a todos (OPAS $^{92}, 1975$; MAINGON $\left.{ }^{66}, 1992\right)$. 
Esta última característica da política pública é que a diferencia das demais políticas. Apenas ela contém decisões que são impostas, pela força ou pelo consenso, a todos da sociedade. Seu uso está diretamente ligado ao uso do poder. O exercicio desse poder constitui monopólio do Estado e tem como finalidade manter e garantir a coesão e a persistência do sistema social. Os conceitos de poder e conflito serão analisados a seguir.

\section{PODER POLITICO, CONFLITO E ARENAS POLITICAS}

A categoria de poder exercido pelo homem sobre o homem, segundo BOBBIO` (1986, p.955), corresponde ao poder politico. É necessário ficar claro que para o poder politico ser exercido não é preciso haver o uso da força. O que o caracteriza não é o seu uso, mas a prerrogativa ou a exclusividade para fazê-lo.

As interações e as relações sociais que conduzem às decisões politicas e ao controle e a revisão dessas decisões, constituem o que se denomina processo político, enquanto os componentes e as estruturas nos quais o processo se realiza constituem o sistema político da sociedade. Nas sociedades modernas nem sempre é fácil distinguir o sistema político do todo social, razão por que "o (sistema) politico pertence ao todo social e está perfeitamente inserido nele" (OPAS ${ }^{92}$ 1975, p.6). Igualmente difícil é identificar, com clareza, os distintos processos politicos que conduzem às decisões e às formulações de políticas. Esses processos podem ocorrer nos espaços oficialmente designados pelo sistema político, mas também podem ocorrer em fóruns extra-oficiais, nos quais atores influentes utilizam seu poder para influir nas decisões políticas.

Existe uma relação estreita entre política e poder, que se situa no limite entre decidir o que fazer - campo da política - e impor essa decisão aos outros - campo do poder. Essa relação associa o exercício do poder politico à "luta pelo poder", ou seja, ao conflito. A politica existe em virtude de existirem conflitos entre os homens e os grupos sociais. A política 
intermedia esses conflitos e a política pública é a única, em decorrência de sua associação com o poder político, que detêm o monopólio do uso da força, quando necessário, no processo de intermediação.

As arenas politicas, também denominadas arenas decisórias ou arenas de luta, são os locais onde se situa o conflito. Nessas arenas, os atores governamentais e os outros atores envolvidos interagem. Ou seja, nelas ocorre o processo politico. As diversas intenções manifestas nas arenas politicas se materializam em decisões e a isso se dá o nome de processo decisóno, definido, segundo HOPPE e col. (USP ${ }^{125}, 1988$ ), como o "diálogo entre as intençres e as ações".

Nem sempre as arenas políticas têm visibilidade. O locus do conflito pode se dar em foruns formalmente institucionalizados, assim como, em virtude da complexidade do exercício do poder politico, em arenas de identificação mais dificıl LOW/63 (1964), classifica as arenas politicas, que ele chama de arenas de poder, em distributivas, regulatórias e redistributivas.

Nas arenas distributivas situam-se as politicas de subsidio público. Como habitualmente se constituem em políticas que podem ser desagregadas e tratadas em partes, é mais fácil, nessas arenas, acomodar os conflitos.

As políticas tratadas nas arenas regulatórias são mais dificeis de ser desagregadas e de ser tratadas em vários itens, correspondendo a sanções, penalidades e proibições. Envolvem interesses, muitas vezes fortes, de grupos. Não sendo possivel o consenso, a coerção na implantação da politica coexiste com processo conflitual mais intenso do que com políticas distributivas. 
Nas arenas redistributivas, as politicas afetam grupos especificns de pessoas e geralmente são relacionadas a interesses de minorias, (população carente e menores abandonados e sem acesso a serviços básicos, por exemplo). O conflito que se estabelece nessas arenas é entre o "ter" e o "não ter". Esse conflito pode ser mais forte do que observado nas politicas regulatórias, desde que os atores que defendem os interesses dos que não têm possuam a capacidade de exercer pressão no processo político.

Fazendo adaptação da posição de alguns autores, entre os quais Lowi, SPITZER ${ }^{114}$ (1995, p.233) refere-se a quatro tipos de arenas politicas, acrescentando às três de Lowi uma quarta, que denomina constituinte ou legal (constituint, em inglês). $\mathrm{Na}$ arena constituinte estão inseridas as políticas que se referem às "regras do jogo". O foco de atenção dessas politicas são o próprio governo e as autoridades governamentais.

Segundo Spitzer, citado no parágrafo anterior, as politicas públicas nem sempre existem em "estado puro"; ou seja, dificilmente se apresentam como exclusivamente distributivas, redistributivas, regulatórias ou constituintes. Costumam-se apresentar em formas mistas e, além disso habitualmente interagem entre si. Na Figura 1, adaptada dos trabalhos de Spitzer, são mostrados alguns exemplos de politicas puras e mistas, de cada uma dessas arenas de poder. 


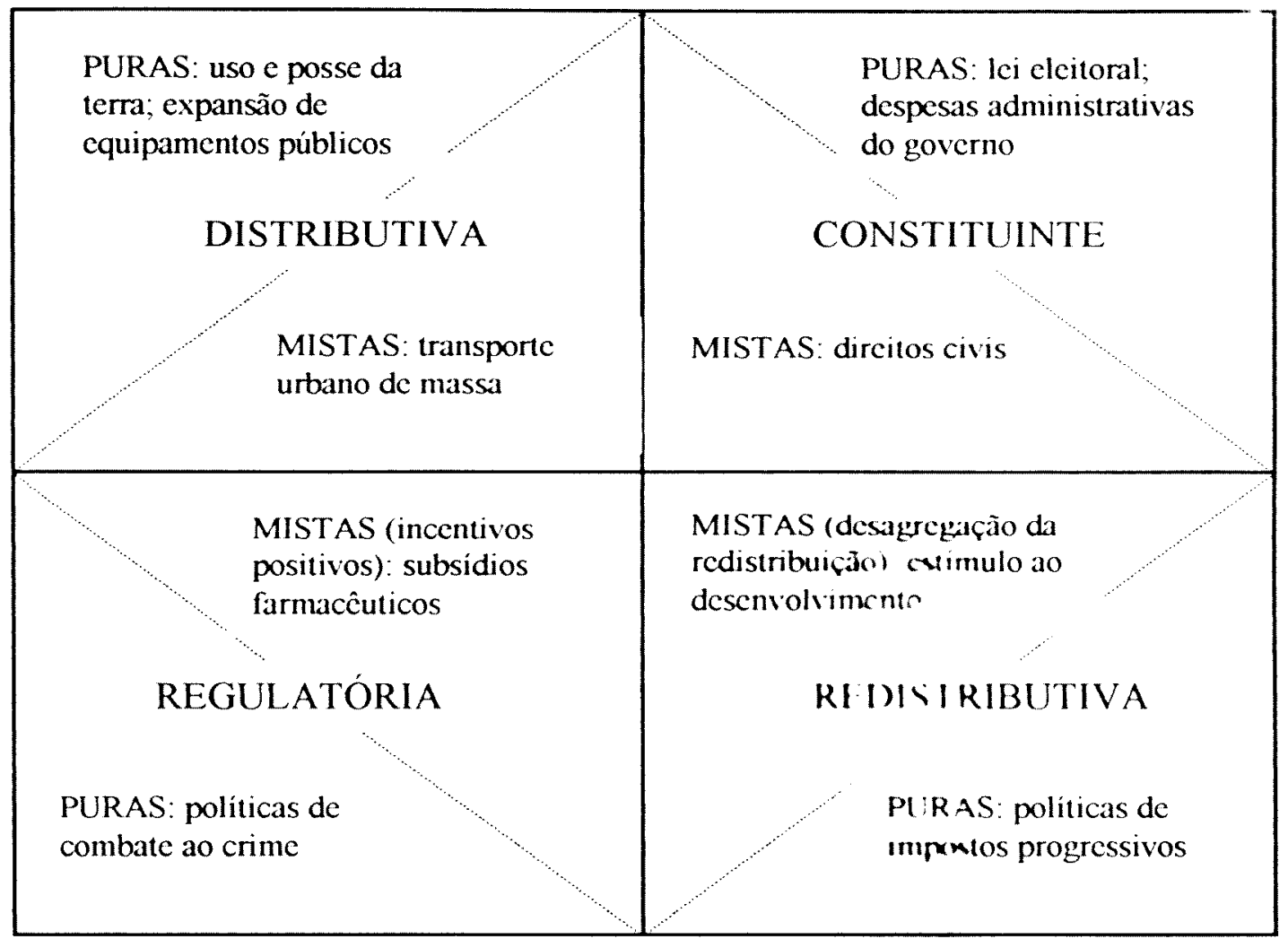

Figura 1 - Arenas de poder, com exemplos relativos a politicas puras e mistas (adaptada de Spitzer RJ. Promotin policy theor In: McCool DC. Public policy. Theories, models and concepts New Jersey: Prentice Hall; 1995. p.233-244).

Nessa figura, cada uma das arenas politicas é representada por um retângulo, em que são apresentados exemplos de politicas puras e mistas. Apesar dos exemplos se aplicarem de forma mais apropriada à realidade norte-americana, eles podem contribuir para estabelecer a tipologia adaptada à realidade de cada país.

De acordo com essa classificação, as políticas puras, que correspondem aos triângulos externos, são mais claramente identificadas com as arenas às quais pertencem, enquanto as politicas mistas, que correspondem aos triângulos internos, têm componentes que interessam também às outras arenas.

Segundo SPITZER ${ }^{114}$ (1995), repetindo o que comentamos anteriormente, a probabilidade de conflito e a necessidade de que sejam 
acionados mecanismos de coerção para a implantação e aplicação das políticas é remota para as distributivas e constituintes e elevada para as regulatórias e redistributivas. O mencionado autor faz exceção para as políticas regulatórias, considerando que estas se dividem em duas formas: econômica e social. As econômicas estão mais próximas das arenas distributivas e as sociais das redistributivas.

Apesar dessa classificação contribuir para ampliar a compreensão do conflito e dos fatores de coerção que se associam à implantação das políticas públicas, persistem, evidentemente, muitos pontos obscuros. Esta análise nem sempre é fácil, especialmente quando a politica pública envolve múltiplos processos políticos.

CARVALHO e COSTA ${ }^{2:}$ (1988) propõem uma forma interativa de análise de políticas públicas, incluınđo nessa análise as arenas politicas e também determinados processos politicos nos quais se dá a formação da denominada agenda de governo Para o entendimento dessa proposta, que será apresentada a seguir, é necessário conceituar "agenda", termo que tem, no campo das ciências politıcas, sido definido como "a relação dos assuntos que mereceram a atenção dos formuladores de políticas". Alguns desses assuntos são priorizados e entram na lista dos que serão decididos; os outros são descartados.

Os fatores que fazem um assunto sobressair e entrar na agenda, ser descartado ou priorizado, são os mais diversos. Dependem do tipo de agenda, dos diferentes contextos sócio-políticos em que ela está sendo construida e da racionalidade dos que são responsáveis por sua elaboração. KINGDON (USP ${ }^{125}$, 1988) refere-se a três tipos de agenda: sistêmica, governamental e decisória ou política 
A agenda sistêmica é a agenda não-governamental, isto é da sociedade. Ela é constituída por demandas e problemas que se tornaram relevantes na sociedade

A agenda governamental contém a lista de assuntos que mereceram a atenção das autoridades, fato que pode ocorrer como decorrência das seguintes situações: (1) crises sociais ou políticas que os tornaram relevantes; (2) em virtude de que indicadores relacionados aos assuntos chamaram a atenção das autoridades, ou (3) porque experts, especialistas naquela área, chamaram a atenção sobre o assunto.

A agenda decisória contém a lista de assuntos que serão decididos, isto $\dot{e}$, os assuntos que foram priorizados. O fator determinante de que uma parte dos assuntos que compõe a agenda governamental passe para a agenda decisória e a outra parte seja descartada depende de influências e pressces dos diferentes atores que interagem no processo político e da capacıdade de intervenção dos atores em interação, ou seja, do poder que têm para tratar do assunto.

$\mathrm{Na}$ literatura, a terminologia utilizada para designar as agendas nem sempre é a mesma. Na abordagem interativa de análise de políticas, proposta por CARVALHO e $\operatorname{COSTA}^{25}$ (1988), a noção de agenda é desdobrada em duas: agenda societária e agenda institucional de governo. A agenda societária, ou sistêmica, é resultante "do conjunto das demandas sociais - latentes ou manifestas - (que) se introduzem na agenda societária por intermédio dos meios de organização disponíveis ... ". Nessa agenda estão os assuntos que emergem da sociedade e assumem dimensão pública. A agenda institucional de governo é definida por CARVALHO e $\operatorname{COSTA}^{25}$ (1988) como referente aos assuntos que serão submetidos à decisão do governo. Na proposta desses autores deve-se, num primeiro plano, reconhecer que existe um processo político mais amplo, no qual a natureza do governo e a racionalidade e o interesse dos governantes 
selecionam os problemas que terão lugar na agenda pública, de goveriı, e serão objeto de decisão política. A porta de entrada para a agenda de governo costuma ser a agenda societária. Essa, porém, não é uma regra fixa. Podem ocorrer pressões particularizadas de grupos econômicos ou de outros grupos de pressão que procuram interferir no governo para fazer prevalecer seus interesses e agem por outras portas de entrada, "oficiosas".

Além desse primeiro plano, que contêm o processo político mais amplo, outros devem ser levados em conta, relacionados com o nível da politica em si, que, apesar de sofrerem influência do processo mais amplo, têm suas especificidades. Ou seja, para a análise da política é necessário considerar esses dois planos: um geral, que interfere no conjunto das políticas e no qual diferentes pressões, legítimas e ilegitimas, influem nas decisões de governo, e um especifico, cujas caracteristicas variam para cada politica em particular.

Nesse plano mais específico, no âmbito da política em si, dois processos políticos merecem destaque; o sistema de decisão e o sistema de participação política. Esses dois sistemas e o assunto em pauta, ou seja o assunto ao qual se refere a politica, estruturam-se e interagem num processo permanente. O conjunto formado por esses três elementos: sistema de decisão, sistema de participação politica e assunto constituem a unidade básica de análise.

Na análise de uma determinada política pública, como é o caso da política de municipalização da saúde, conforme nossa dedução, é importante identificar como se constitui sua unidade básica de análise. Quem decide a respeito daquele assunto, quais são os atores participantes e de que forma eles participam, por exemplo. Feito isso, o passo seguinte é investigar a arena politica onde se vai dar o confronto: distributiva, redistributiva ou regulatória. Quando o assunto em questão exacerba conflitos que impedem o seu encaminhamento, em decorrência da reaglutinação de forças políticas 
e sociais opositoras, e isso ocorre em geral nas politicas de caráter redistributivo, ele é encaminhado a outras arenas políticas. Não ocorre a acomodação do conflito. Como, em decorrência da natureza do assunto, ele nem sempre pode ser resolvido nas outras arenas, retorna de tempos em tempos, assumindo uma forma circular. A reflexão a respeito do comportamento linear ou circular dos assuntos permite compreender a composição das forças politicas e sociais, sua organização e as ações politicas desenvolvidas

\section{POLITICAS PÜBLICAS "SOC.A.S" E "NÃO-SOCIAIS"}

As politicas socias constituem tipo particular de politicas públicas que, segundo MAINGON * (1992, p.5), "tem limites muito vagos e conteúdos muito amplos". Apesar das dificuldades semânticas de utilização do termo "social", pode-se considerar as políticas sociais como responsáveis por alcançar objetivos relacionados ao bem-estar da população. Nessa perspectiva, existe consenso em classificar politicas de saúde, de educação, de seguridade social e de habitação, como exemplos de políticas sociais.

A distinção entre politıcas sociais e econômicas nem sempre é fácil. Diferenciam-se, segundo Maingón, porque, apesar de ambas serem politicas públicas, as econômicas estão centradas nos processos de acumulação e as sociais nos de distribuiçāo.

O conflito está mais presente nas políticas sociais do que nas outras políticas, em virtude de seu habitual caráter redistributivo. Em situação de desigualdade na efetivação de direitos, como serve de exemplo o que ocorre na América Latina, o aspecto redistributivo é marcante. A investigação das políticas sociais adquire maior importância em virtude de que ela contribui para identificar os valores predominantes na sociedade. A origem da politica social, como afirma FERNANDEZ (1987 apud MAINGÓN ${ }^{\star 6}$ 1992, p. 6) é o "resultado da dinâmica de processos conflitivos ou cooperativos entre demandas de distintos grupos e atores com diferentes interesses e valores 
acerca do que deve ser a sociedade". Essas políticas, mais do qu: as econômicas, estão diretamente relacionadas à solidariedade social na sua implantação.

\section{ELEMENTOS BÁSICOS DAS POLITICAS PÚBLICAS E O SUS}

As políticas públicas tem dois elementos básicos: uma imagemobjetivo e um sistema de decisões.

A imagem-objetivo representa a finalidade última da politica. O Sistema Único de Saúde (SUS), conforme por exemplo, preconiza a Reforma Sanitária, tem como imagem-objetivo a crinsecução dos principios que compõe o seu ideário. Este, que por sinal faz parte do seu marco juridico-legal, adota os princípios de cobertura universal, eqüidade, descentralização, integralidade e participação popular.

O sistema de decisões é formado pelo processo político ou, as vezes, pelo conjunto de processos-políticos que conouzem à formulação e à implementação das ações que devem promover a efetivação da política. $O$ SUS tem um sistema de decisões que se caracteriza por ter vários processos políticos. Esse sistema está disperso em vários campos e envolve distintas áreas de poder, fato não incomum, que constitui, aliás, uma característica freqüente das políticas públicas. De acordo com SALAZARVARGAS $^{106}$ (1995 p.30), as políticas públicas "em geral, envolvem um conjunto ou 'rosário' de decisões que se podem dar de forma simultânea ou seqüencial".

A efetivação do SUS envolve decisões que devem ocorrer, por exemplo, com relação à política farmacêutica, combate a endemias, prestação de serviços assistenciais, regulação do setor privado médicohospitalar, vigilância sanitária, combate a doenças imunopreveníveis, entre muitas outras. 
Uma das preocupações deste estudo foi a de procurar identificar os componentes do sistema de decisão das políticas locais de saúde no âmbito do poder local. Além dos governantes locais, prefeito e secretário de saúde, por exemplo, outros atores locais incorporam-se ao processo de decisões, já que, pelo marco legal, a municipalização da saúde deve ter gestão participativa. Os governos locais devem incorporar atores locais nãogovernamentais no seu sistema de decisões. A estratégia operacional utilizada pela Reforma Sanitária foi a constituição dos Conselhos de Saúde, que são um pré-requisıto obrigatório à municipalização.

Os Conselnos Municipais de Saúde, portanto, fazem parte do sistema de decisões das politicas locais de acordo com a legislação do SUS. Houve preocupação neste estudo em procurar dimensionar o peso dos Conselhos nas decisões. Exıstem Conselhos de Saúde que são "tutelados" pelo poder executivo e outros que têm maior liberdade de ação. Procurou-se investigar, no estudo empirico que realizamos, a relevância do Conselho Municipal de Saúde no processo decisório, partindo do pressuposto de que um dos constrangimentos a que está submetido para o exercicio do poder advêm da situação concreta de relação, tutelada ou autônoma, que mantêm com o poder executivo

Outros constrangimentos derivam dos limites do poder local, havendo necessidade de diferenciar a origem das limitações. Dito de outra forma, o papel do sistema de decisões, depende não só da postura democrática dos governos locais, mas também das limitações do poder local frente às decisões nacionais. Procurou-se analisar, com preocupação especial, essa questão no estudo de caso, como se verá adiante. 


\subsubsection{Planejamento e participação na gestão da saúde municipal}

Para os propósitos deste estudo é necessário assinalar diferenças e semelhanças que existem entre a gestão participativa e o planejamento participativo.

A gestão participativa preconizada pela municipalização da saúde diz respeito à incorporação de atores locais ao processo decisório das politicas de saúde. Como já comentamos, a institucionalização dos conselhos municipais e locais de saúde é a principal estratégia operacional utilizada para promover a participação na gestão. Esses canais permitiriam, segundo a estratégia da Reforma Sanitária, que grupos locaıs, tais como prestadores de serviço, usuários e associações de doentes, entre outros, pressionassem e influenciassem na decisão das politicas locais. A expectativa do movimento sanitário é a de que esses canais contribuam para melhor fiscalização na aplicação dos recursos, democratização do processo decisório e para a efetivação do SUS.

O planejamento participativo em saúde também diz respeito à incorporação de novos atores ao processo decisório. No campo do planejamento em saúde também existem intenções de ampliação da participação nas decisões. Enquanto no campo da gestão, ou seja, da política, no uso do poder político, a origem da ampliação da participação pode ser explicada pela trajetória da Reforma Sanitária brasileira, no campo do planejamento, a origem é outra. A incorporação de novos atores ao processo de decisão pode ser compreendida a partir da trajetória histórica do planejamento em saúde na América Latina.

De acordo com CHORNY ${ }^{31}$ (1990), o planejamento em saúde na América Latina é caracterizado por três fases distintas: normativa, estratégica e pensamento estratégico aplicado ao planejamento. Essas fases, de acordo com o pensamento desse autor, são sintetizadas a seguir. 
A primeira fase, do planejamento normativo, tem forte influência do método CENDES/OPAS. Esse método teve origem entre os anos de $1962 \mathrm{e}$ 1963, em uma conjuntura histórica muito particular, que privilegiava o racionalismo e a "cientificidade" na busca de um mundo melhor. Tendo como idéias centrais a eficiência na aplicação dos recursos e a visão do planejador como sujeito independente do todo social, o planejamento não reconhece, nessa fase, o conflito ou, ao menos, a possibilidade de que interfira no processo de planejamento.

Em meados da década de 1970, o planejamento em saúde na América Latina começa a deslocar-se do âmbito da economia e da racionalidade cientifica, própria das ciências físicas e naturais, para o campo das ciências sociais e politicas. O planejamento passa a utilizar-se de "imagem-objetivo", "estratégias" e "planos estratégicos", reconhecendo que existem conflitos no sistema social. Essa nova fase do planejamento, denominado estratégica, além de constituir uma ruptura epistemológica com a fase anterior, caracteriza-se por considerar o conflito e a existência de outros atores que devem ser levados em conta no processo de planejamento.

A ruptura com o modelo de planejamento normativo anterior teve forte influência do documento "Formulación de Politicas de Salud" (OPAS", 1975), publicado pelo Centro Pan-Americano de Planejamento em julho de 1975. Ao criticar o processo de planejamento tradicional e a forma pela qual surgem os planos de saúde, seus autores apontam para a "necessidade de um melhor conhecimento do sistema dos serviços de saúde e da maneira como sua estrutura e funcionamento são influenciados pelo contexto político, social e econômico" (p.1).

O encontro do planejamento com a politica e o reconhecimento do conflito como inevitável na convivência entre os individuos e os grupos 
sociais, que surge com esse novo paradigma, abrem espaços para que sistemas de decisão e de participação se aproximem. Fala-se mais, no âmbito da saúde, tanto em "gestão participativa" quanto em "planejamento participativo". A formulação das políticas de saúde deixa de situar-se na esfera exclusiva do Estado para abrir-se também ao sistema social.

A terceira fase, do pensamento estratégico aplicado ao planejamento, constitui derivações da fase anterior, na qual, mantido o paradigma estratégico, três diferentes enfoques passam a ter destaque: o pensamento estratégico de Mario Testa; o planejamento situacional de Carlos Matus e o enfoque estratégico da Escola de Medelin.

Para Mario Testa, é a partir do estudo do poder que pode ser compreendida a estratégia; coloca em discussão o planejamento, ou seja, "o que fazer", vinculado à análise do poder e da estrutura social e, nesse sentido, sua proposta é mais de intervenção do que da criação de uma metodologia. Matus, por sua vez, preocupa-se menos com os aspectos estruturais e com o político, e mais com o método, procurando dar racionalidade ao processo decisório. A Escola de Medelin tem orientação mais pragmática, estando mais preocupada em aplicar métodos e técnicas.

A fundamentação teórica para analisar a municipalização da saúde deve considerar a influência dos dois campos referidos neste tópico: o da política - ou seja, do poder politico na gestão - e o do planejamento. Nesses dois campos está ocorrendo uma ampliação da participação - ao menos no âmbito do discurso, ou seja da intencionalidade explicita - no processo de decisões.

No campo da política de saúde, percebe-se pelo marco legal da Reforma Sanitária, que o SUS delega poder de participação e de decisão formular, acompanhar, controlar - aos atores locais, instituindo fóruns formais para que isto ocorra. Institucionaliza-se o pluralismo no espaço local 
e a meta é a "gestão participativa". Na investigação desses aspectos as questões que sobressaem são: Quais são as arenas politicas locais? Como o processo decisório local está ocorrendo? Qual é capacidade de intervenção dos atores locais nas políticas do SUS? Qual é a influência do processo político mais amplo, no âmbito do governo central, estadual ou do Estado, na governabilidade dos atores locais?

No campo do planejamento em saúde, a participação nas decisões não foi incorporada a partir de um marco legal, mas em virtude de desenvolvimento epistemológico específico. Ou seja, está na moda falar em "planejamento participativo" e uma das razões desse slogan ter entrado em moda foi a consolidação do pensamento estratégico no ato de planejar em saúde. Na análise das politicas locais de saúde, as questōes mais próprias desse campo são: Como se está dando o processo de planejamento das politicas locais? Quais são os atores que planejam? De que forma os diferentes atores estão interferindo no processo de planejamento? As estratégias locais estão sendo eficientes, no sentido de avaliar o cenário e os ambientes externo e interno às organizações de saúde?

É necessário assinalar que não existem limites muito precisos entre "gestão participativa" e "planejamento participativo". O exercício do poder, de forma coercitiva, para garantir a efetivação da politica, nem sempre é aplicável sem planejamento e estratégia.

\subsection{Aspectos metodológicos do estudo empírico}

\subsubsection{Particularidades do estudo de caso}

MUNICIPIO ESCOLHIDO

A pesquisa foi realizada em um único município, Marilia, no Estado de São Paulo. Foi preponderante nessa escolha a facilidade na obtenção das 
informações necessárias para o estudo. Entre os aspectos favoráveis para a escolha sobressairam: (1) o porte médio do municipio, que the dá a condição de dispor de atores locais representativos dos diversos segmentos e grupos - prestadores de serviços, usuários, profissionais de saúde, segmentos acadêmicos etc. - bem delimitados, e ao mesmo, permitir que se incluam na pesquisa representantes de todo o universo. Em municípios de menor porte os segmentos de atores locais seriam mais restritos e menos facilmente identificados e em municipios de porte muito maior a caracterização dos atores provavelmente seria mais dificil; (2) a disposição dos atores locais em contribuir com a pesquisa - o secretário de saúde, por exemplo, e (3) a facilidade de deslocamentos do investigador para a obtenção dos dados, em virtude da localização geográfica e do acesso.

O município de Marilia, localizado na região Oeste do Estado de São Paulo, como mostra a Figura 2, foi fundado no ano de 1929 e tinha em 1999 população estimada de 188.658 habitantes, com taxa de urbanização de $96,21 \%$. Marilia constitui polo universitário do interior paulista, contando com quatro escolas de ensino superior, com cerca de 15.000 alunos. 


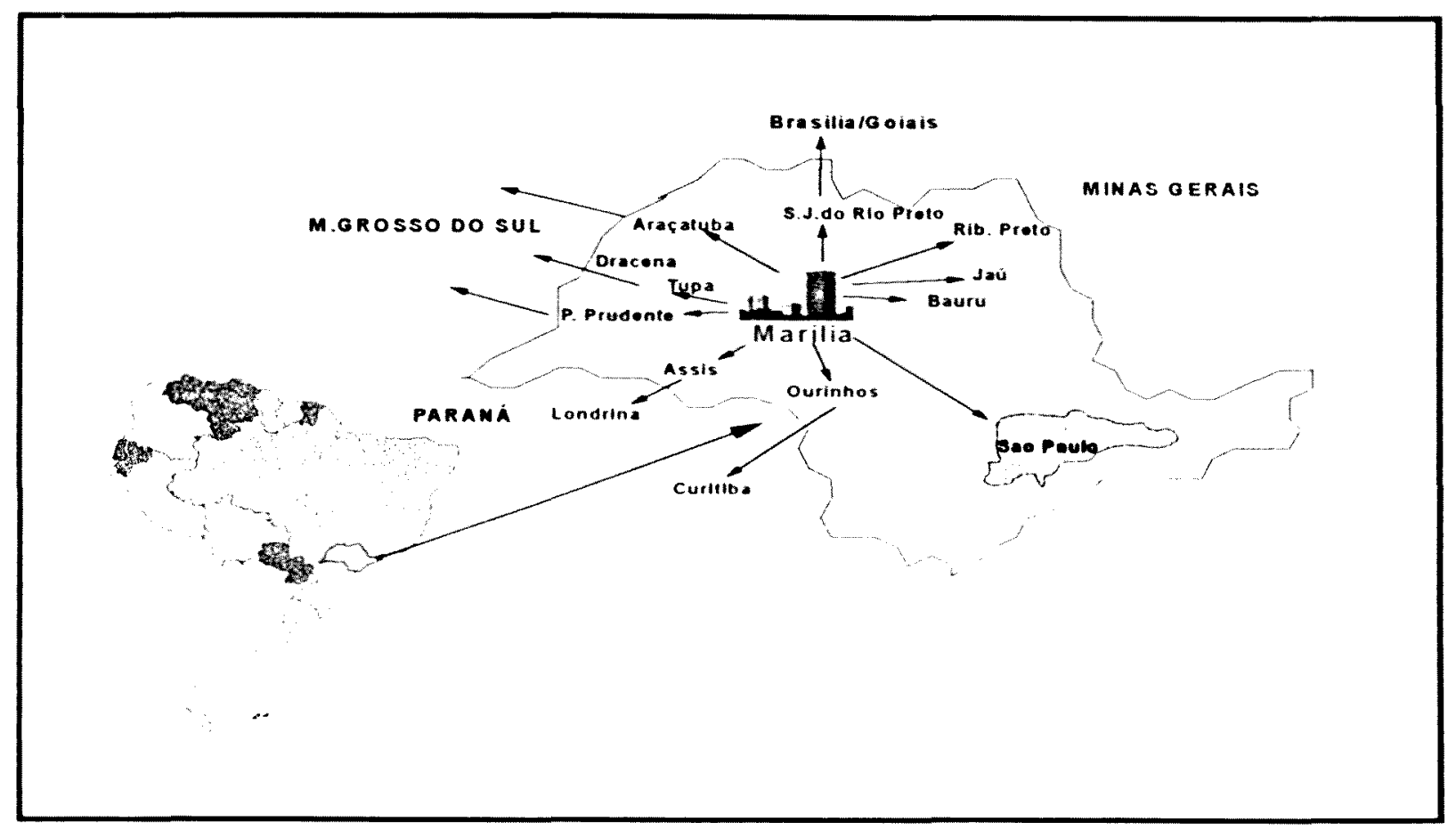

Figura 2 - Localização do municipio de Marilia.

(Figura adaptada da dissertação de mestrado de López LOJGB. Uma aproximação à avaliação da participação comunitária em SILOS: o projeto UNI - Marilia. São Paulo, 1996).

Inicialmente, um dos fatores que pesou contra a escolha desse municipio foi o fato de Marilia não ter assumido a gestão semiplena e ter municipalizado a saúde com maior autonomia - gestāo plena do sistema de saúde, segundo a NOB SUS 96 - apenas em meados de 1998. Outros municipios brasileiros, que assumiram a gestão semiplena, adquiriram essa condição de autonomia alguns anos antes. O histórico do processo de municipalização de Marilia, no entanto, sobrepujou esse aspecto. Mesmo tendo demorado um pouco mais para assumir a gestão autônoma da saúde, o municipio está entre os que vêm desenvolvendo esforços de municipalizar e ampliar seus sistema de saúde há vários anos, com participação política marcante de atores locais.

Como resultado dessa participação pode ser ressaltada a inclusão desse municipio no projeto UNI - Uma Nova Iniciativa na Educação dos Profissionais de Saúde: União com a Comunidade - a partir de 1993. Esse 
projeto, que procura integrar a universidade, os serviços de saúde e a comunidade local, e tem como objetivo contribuir para a indução de mudanças organizacionais e dos modelos de saúde tradicionais (KISIL e CHAVES $\left.^{59}, 1994\right)$, ampliou a visibilidade dos processos politicos no âmbito da saúde, contribuindo, conseqüentemente, para a análise das politicas de saúde nesse municipio.

\section{VALIDADE INTERNA E GENERALIZAÇÃO DOS ESTUDOS DE CASO}

A estratégia de pesquisa que se baseia em estudo de caso único, de acordo com CONTRANDRIOPOULOS e col. ${ }^{35}$ (1997, p.35), possui um alto potencial de validade interna, embora as generalizações devam ser feitas com ressalvas. Ou seja, os resultados terão mais validade para a realidade de Marilia do que para os municipios em geral.

Apesar disso, porém, no caso deste estudo procurou-se realizar a análise dos dados fazendo permanente incursão do particular para o geral e vice-versa. Ou seja, os dados empíricos procuraram captar, sempre que possivel, características gerais do processo de municipalização da saúde que costumam ocorrer em todos os municipios. As informações obtidas com o estudo de caso foram utilizadas para identificar e analisar as variáveis envolvidas com o assunto $e$, além da influência dessas variáveis no processo ocorrido em Marilia, procurou-se inferir as possiveis influências em realidades distintas, especialmente no capítulo final, ao confrontar os achados empíricos com os pressupostos do estudo.

Essa estratégia metodológica foi utilizada com o objetivo de ampliar o potencial de generalização do estudo. Os estudos de caso têm, segundo LUDKE e col. ${ }^{64}$ (1986, p. 18-21), como uma de suas características permitir generalizações quando o leitor, ao lê-lo, pode mais facilmente indagar o que é possivel de ser aplicado em outra situação. 
Para a obtenção dos dados foram utilizados dois instrumentos: pesquisa documental e entrevistas.

\section{PESQUISA DOCUMENTAL}

Esse tipo de pesquisa tem como vantagem, segundo QUIVY e CAMPENHOUDT'10) (1992, p.203), "economia de tempo e dinheiro, que permite ao investigador consagrar o essencial de sua energia à análise propriamente dita". Seus fatores limitantes referem-se à possibilidade de acesso aos documentos e à existência desses registros.

Foram analisados os seguintes documentos (1) atas das reuniões do Conselho Municipal de Saúde; (2) atas das reunides dos Conselhos Locais de Saúde; (3) relatórios das Conferências Municipaıs de Saúde; (4) relatórios de pré-conferências de saúde; (5) decretos e leis relacionados à saúde e ao meio ambiente, e (6) planos de saúde do governo local.

O período analisado obedeceu à cronologıa dos próprios eventos relacionados aos documentos. As atas do Conselho Municipal de Saúde, por exemplo, foram analisadas desde a sua criação, em 21 de fevereiro de 1991. Os documentos referentes aos Conselhos Locais de Saúde, por outro lado, foram bem posteriores, já que foram criados vários anos depois. Não foi realizada, propositadamente, delimitação precisa de tempo, por considerar esse aspecto irrelevante e até incompativel com a estratégia da pesquisa. A referência básica, no entanto, são as décadas de 1980 e 1990, pois esse foi o período histórico que coincide com o processo de municipalização da saúde no país.

\section{ENTREVISTAS}

Foram realizadas entrevistas semi-estruturadas com os seguintes atores locais: secretários e ex-secretários de saúde, prefeitos, técnicos e assessores da secretaria municipal de saúde, lideranças de usuários, lideranças sindicais com envolvimento na área da saúde, prestadores de 
serviço e jornalista, entre outros, num total de 21 entrevistas. No anexo 1 estão especificadas as funções exercidas pelos entrevistados.

A escolha dos atores considerados relevantes para o desenvolvimento da pesquisa deu-se por causa do envolvimento dos mesmos no processo de municipalização da saúde. O roteiro das entrevistas (gravadas com autorização prévia dos entrevistados), que teve pequenas variações em função do desenvolvimento da entrevista, fundamentou-se em três perguntas básicas: Quais são as suas impressões a respeito do processo de municıpalızação da saúde do municipio de Marília? Quais foram os fatores que vocè acha que mais influíram no processo de municipalização da saúde no munıcipıo de Marília? Que sugestões você teria a dar para o aperfeiçoamento do processo de municipalização da saúde em Marilia?

\subsubsection{Hipóteses ou pressupostos}

Os passos metodológicos ou operacionais de uma pesquisa habitualmente são apresentados de forma seqüencial, no qual se elaboram hipóteses, institui-se um modelo de análise ancorado pelo arcabouço teórico e classificam-se e ordenam-se dados, para, a partir de categorias empiricas, fazer a interpretação e análise dos resultados. Na prática, não existe separação rigorosamente precisa entre essas etapas. No processo investigativo ocorre habitualmente interação desses diferentes momentos e, para facilitar a compreensão, eles são, como neste caso, apresentados separadamente.

As hipóteses constituem, segundo QUIVY E CAMPENHOUDT ${ }^{100}$ (1992), respostas provisórias às perguntas que suscitaram o processo de investigação. No seu sentido puramente positivista, hipóteses estabelecem relação entre uma causa e um efeito suposto e, nesse sentido, teriam que ser comprovadas ou refutadas (CONTRANDRIOPOULOS e col. ${ }^{35}$, 1997). Em uma abordagem dialética, no entanto, representam "o que o investigador 
deseja esclarecer" (TRIVIÑOS ${ }^{124}$ 1987, p.107), não necessitando ser objetivamente comprovadas. Segundo MINAYO ${ }^{85}$ (1989, p.130), no enfoque dialético as hipóteses servirão de "caminho e baliza no confronto com a realidade empírica".

Pressupostos tem sido utilizado por alguns autores para substituir o termo hipóteses, exatamente para evitar confusões que podem surgir quando se utilizam hipóteses, em estudos qualitativos no âmbito das ciências sociais. Na definição de MINAYO $^{87}$ (1999, p.95), por exemplo, pressupostos são "alguns parâmetros básicos que permitam encaminhar a investigação empirica qualitativa". Aderindo a essa sugestão, apresentamos os pressupostos do nosso estudo:

\section{PRESSUPOSTO 1:}

O deslocamento de poder propiciado pela municipalização da saúde, apesar de limitado por obstáculos que fogem do domínio dos atores locais, permite que os processos politicos que ocorrem no municipio interfiram positivamente no controle social e na ampliação do atendimento aos direitos em saúde.

Este pressuposto aponta para uma leitura otimista das potencialidades do poder local. O otimismo não está relacionado, nesse caso, aos resultados obtidos, mas às potencialidades do processo. A municipalização da saúde permite interferência do poder local no direcionamento das políticas de saúde. Essa interferência pode dar-se com a ampliação do controle social e com a melhoria da qualidade do sistema de saúde. Esse pressuposto tern o seu contraponto: a interferência do poder local pode também ser negativa. Neste caso, podem prevalecer nos processos políticos locais os interesses que reduzem o controle social e pioram a qualidade do sistema de saúde. 
Entre esses dois pólos, devem-se considerar, na prática, diferentes nuanças e graus de interferência, mais próximos da interferência positiva ou da negativa. O que esse pressuposto ressalta, no entanto, é a existência do poder local. Ou seja, os municipios não são, necessariamente, meras instâncias burocráticas de racionalização e corte de despesas, podendo interferir no rumo dos acontecimentos, mesmo que de forma limitada.

\section{PRESUPOSTO 2:}

A capacidade de interferência do poder local no direcionamento das políticas de saúde está limitada a determinados assuntos. Esse "rol" de assuntos configura os limites do poder local. Seu descarte ou inclusão na agenda decisória local está condicionado à interação de complexos mecanismos de decisão e de participação politica dos atores locais.

Diversos fatores influem na escolha dos assuntos que serão tratados de forma prioritária na formulação das politicas locais. Existem assuntos que são do âmbito do poder local, enquanto outros, não. Por exemplo, politicas que regulam industrialização e comércio de insumos e equipamentos médicos ou o uso de sangue e hemoderivados, entre muitas outras, são tratadas habitualmente de forma centralizada. Há outros assuntos que dizem respeito claramente aos problemas locais, como por exemplo: reorganização da atenção básica à saúde e programação de compra de serviços ambulatoriais e hospitalares de prestadores privados. A opçāo de priorizar alguns em detrimento de outros depende de dois fatores: o sistema de decisões e a participação dos atores.

\section{PRESSUPOSTO 3:}

A priorização de assuntos e a formulação de políticas locais condizentes com o paradigma da Reforma Sanitária pode gerar conflitos no sistema de decisões e na interação dos atores. Gestores locais comprometidos e capacitados contribuem para a superação desses conflitos, com planejamento e condução adequada da política. 
A municipalização da saúde depende da existência de "sujeitos" que conduzam estrategicamente as mudanças no sistema de saúde local. Esses sujeitos são os gestores locais, secretário de saúde e seus assessores, isto é, os agentes públicos que estão no poder. Além de partilhar do paradigma da Reforma Sanitária, os gestores locais devem estar capacitados para conduzir o planejamento do sistema de saúde. Esse pressuposto aponta para a necessidade de investigar o processo político integrado com o processo de planejamento das politicas locais de saúde. Os condutores locais da política são agentes políticos e administrativos. O conflito entre atores gera demandas ligadas a recursos de poder e de habilidade de negociação e superação de conflitos por capacidade de liderança (visão estratégica, capacidade de condução de politicas etc.). Em outras palavras, os gestores locais devem saber utilizar o poder político que lhes foi disponibilizado pelo processo de municipalização com habilidades de líder, para maximizar o potencial de mudança das práticas sanitárias.

\section{PRESSUPOSTO 4:}

A municipalização da saúde convive com dificuldades relacionadas ao 'que fazer' e ao 'como fazer'. Essas dificuldades não se devem apenas a obstáculos existentes no campo político-administrativo, mas também no campo teórico e prático da Reforma Sanitária.

O que fazer, aqui referido, diz respeito à imagem-objetivo do Sistema Único de Saúde. O como fazer refere-se à implementação de ações técnicooperativas concretas que aproximem o sistema de saúde municipal da imagem-objetivo. Além dos obstáculos implicitos nos três pressupostos anteriores, a municipalização da saúde convive com uma dificuldade não superada pela Reforma Sanitária, que é a de traduzir suas intenções em práticas concretas, por causa da inexistência de caminhos absolutamente claros para transformar o atual modelo de saúde. Ao lado do modelo hegemônico surgem propostas de "modelos alternativos" que estão em 
experimentação no país. Esse pressuposto traz um elemento adicional a ser considerado na análise da política local, que diz respeito às dúvidas e incertezas que persistem nos campos do saber e prática da Reforma Sanitária.

\subsubsection{Categorias empíricas}

O sistema de decisões das politicas locais de saúde constituiu a categoria empirica principal. Essa categoria é composta de vários componentes. Alguns tem maior visibilidade, podendo ser facilmenie identificáveis, por estarem mais institucionalizados. Fazem parte desse grupo: (1) decisões dos governantes locais da área da saúde; (2) Conselno Municipal da Saúde, e (3) Conselhos Locais de Saúde. Em cada um desses três grupos ocorrem processos politicos que, em tese, podem influenciar no direcionamento das políticas locais de saúde.

Existem outros componentes do sistema de decisões das politıcas locais de saúde que não têm a mesma visibilidade. Nesses componentes, não tão visiveis, também se manifestam interesses de atores, que exercem influências e pressões diversas nos processos decisórios e, certamente, também influem no direcionamento das politicas. Esses diferentes inputs ao processo decisório devem ser considerados na análise da política, buscando identificá-los tanto no estudo empírico quanto na confrontação deste com a teoria que dá suporte à análise.

Para facilitar o estudo dessa categoria empirica - sistema de decisões das políticas locais de saúde - foram utilizadas algumas pré-categorias: (1) visibilidade dos atores; (2) interesse dos atores, e (3) agenda decisória.

A visibilidade dos atores contribui para dar uma condição mais homogênea à classificação dos dados. Os governantes locais (ou gestores), os prestadores de serviço, os profissionais de saúde, os usuários, os 
representantes da Universidade, entre outros, constituem exemplos de conjuntos de atores específicos.

Os interesses dos atores, explicitos no discurso dos mesmos, ou implícitos e inferidos pelo estudo do seu comportamento e pela análise de sua estrutura de relevância, permitem igualmente dar tratamento analítico mais homogêneo a esse tema. Esses interesses são considerados não apenas pela sua expressão mais imediata no processo político, mas pelo seu significado mais abrangente. Sua apreensão procurou levar em conta o contexto sócio-histórico de inserção desse ator no processo de interação, conforme propõe a abordagem dialétıca

A agenda decisória é constituida pelos assuntos que adquiriram o status de compor a agenda. Essa pré-categoria foi subdivida em lista de assuntos homogêneos, classificados por temas especificos e por fatores que influenciaram a entrada do assunto na agenda. Esses grupos homogêneos de assuntos surgiram após leitura repetıda dos dados coletados e, portanto, da realidade empírica e não de uma proposta prévia.

Para a classificação, ordenamento e interpretação dos dados, os documentos principais foram os seguintes: atas do Conselho Municipal de Saúde, atas dos Conselhos Locais de Saúde, diretrizes de saúde do governo local e registro transcrito das entrevistas gravadas. O material relativo às Conferências Municipais de Saúde, Planos de Saúde, Leis e normas da saúde, de origem local, entre outros, fornecem subsídios adicionais de informações para a análise dos dados e sua interpretação.

\subsubsection{Aspectos operacionais da análise de dados}

ASPECTOS OPERACIONAIS DE ANÁLISE DAS ENTREVISTAS

Foram realizadas 21 entrevistas, nas quais se procurou obter informações sobre: (1) percepção do processo, pelo ator; (2) interesses do 
ator e (3) fatores que influenciaram sua ação política no decorrer do processo.

Inferiu-se a percepção do processo por manifestações que foram registradas ao longo da entrevista e em cujo conteúdo era possível apreender o significado que tinha, para o entrevistado, o processo de municipalização da saúde, considerando o contexto de sua inserção e sua história de vida. Essa preocupação de identificar as diferentes racionalidades na interpretação da realidade tem como pressuposto o pensamento de Carlos Matus (HUERTAS ${ }^{\varsigma 6} 1996$, p.30), segundo a qual, na interação entre atores sociais, "cada ator retira da realıade uma interpretação dos fatos, conforme as lentes com que os observa" Existem, em sua opinião, "distintas verdades" construidas pelos atores para explicar a realidade e essas explicações atendem os interesses dos atores

Procurou-se identificar os interesses manifestos ou implicitos, da participação política do ator, considerando, como afirmamos acima, que todo ator tem, no processo de interação politıca com outros atores, algum interesse que deseja ver prevalecido.

A identificação dos fatores que influenciam a ação política dos atores que interagem no processo politico permitiu investigar elementos de racionalidade que moldam suas estratégias políticas e ter noção do significado de alianças e divergências que se estabelecem.

É necessário ressaltar que o termo ator, utilizado neste estudo, referese ao conceito de ator social, conforme preconiza MATUS ${ }^{77}$ (1997). Segundo esse autor, os atores sociais "são forças sociais e personalidades que controlam centros de poder". Matus afirma, a respeito da capacidade de intervenção política dos atores sociais:

Nosso interesse pelos atores sociais advém de seu papel no processo de produção social. Eles são os únicos produtores coletivos de 
eventos sociais, e, portanto, são os sujeitos da mudança situacional. Esses atores podem seguir um processo de produção direta, utilizando o poder que têm em si como instituições, ou um processo de produção indireta, através das instituições que controlam (p.228).

De acordo com Matus, os atores sociais podem ser pessoas isoladas ou grupos (organizações, instituições etc.) mas devem ter as três características seguintes: (1) algum grau de organização; (2) alguma capacidade de intervenção, e (3) um projeto de intervenção. O individuo isolado ou grupos desorganizados, que não conseguem dar organicidade, mesmo que minimamente, a um projeto politico, não tendo, por consequencia qualquer capacidade de interferir no processo politico, não podem ser considerados atores sociais.

No que diz respeito à análise dos dados encontrados, é necessário assinalar que a subjetividade do pesquisador e a impossibilidade de neutralidade no tratamento do objeto, no campo da pesquisa social, pode interferir na interpretação das informações. Procurou-se separar o dado de sua interpretação, cuja responsabilidade é do autor deste estudo e do uso dado ao marco teórico utilizado. Essa constitui uma das formas de interpretar a realidade estudada, não sendo a única nem a definitiva, podendo representar, no máximo, como afirma MINAYO ${ }^{87}$ (1999), uma contribuição à aproximação do conhecimento da realidade.

ASPECTOS OPERACIONAIS DE ANÁLISE DAS ATAS DO CONSELHO MUNICIPAL DE SAÚDE

Em relação às atas das reuniões do Conselho Municipal de Saúde procurou-se analisar os diversos assuntos em alguns conjuntos especificos, com o objetivo de dar maior homogeneidade às informações. Essa classificação dos assuntos tratados, adotando proposição de KINGDON (USP $\left.{ }^{125}, 1988\right)$, foi realizada levando em consideração: a) o tipo de assunto; b) o fator de relevância do assunto, ou seja, o que o tornou relevante, e c) o destino dado ao assunto. 
(a) TIPO DE ASSUNTO

Os assuntos que surgiram nas reuniões dos conselhos foram classificados em alguns conjuntos de assuntos para facilitar a análise. A escolha dos conjuntos fundamentou-se na leitura exaustiva das atas, procurando-se identificar semelhanças entre os temas tratados, como propõe Minayo, com o objetivo de estabelecer alguma ordem na aparente desordem propiciada pelos dados. Os conjuntos de assuntos utilizados foram:

(1) assuntos regimentais: relativos à discussão do regimento interno, à presença ou ausência de conselheiros, quórum, exclusão e reintegração de conselheiros etc;

(2) propostas gerenciais e assistenciais locais: ampliação ou redução dos serviços que prestam assistência ao SUS, politicas de saúde para grupos específicos (criança mulher, idoso, etc.), avaliação sobre o atendimento de urgência/emergência etc;

(3) relacionados a campanhas e programas de saúde nacionais e estaduais: prevenção de endemias, informe e operacionalização de campanhas nacionais de multivacinação, controle do dengue, informe e operacionalização de programas formulados pelo Ministério da Saúde ou pela Secretaria Estadual de Saúde;

(4) reclamações sobre qualidade da assistência ou sobre remuneração dos serviços prestados para o SUS: solicitação de abertura ou ampliação de serviços, reajuste de pagamentos, queixas e denúncias sobre cobranças indevidas etc;

(5) relacionados à ampliação ou ao aperfeiçoamento do controle social: realização e organização de conferências de saúde, apreciação e aprovação de contas do FMS ou de convênios do SUS etc. 
(b) FATOR DE RELEVÂNCIA DO ASSUNTO

Os assuntos entraram na pauta do CMS, evidentemente por algum motivo. Em geral, quem organiza a pauta são os coordenadores da reunião, que, no presente caso, foram os governantes locais. A inclusão dos assuntos na pauta, no entanto, tem influências diversas, nem sempre relacionadas à pura vontade dos governantes locais. Além disso, surgem assuntos extra-pauta, incluidos por outros participantes ou outros fatores. Para pesquisar esses fatores procurou-se identificar quais atores, organizações ou instituições trouxeram esses assuntos para a agenda do CMS.

Utilizou-se, para identificar a origem dos assuntos da agenda e o que os tornou proeminente, a seguinte classificação: (1) governo federal ou estadual (normas ou decisões que tiveram origem na União ou no governo do estado (geralmente ministério da saúde ou secretaria estadual de saúde); (2) governantes locais (entraram na agenda por decisão do Secretário ou sua equipe); (3) usuários; (4) prestadores de serviço; (5) profissionais de saúde; (6) crise ou eventos dramáticos (situações que geram comoção ou escândalo, como, por exemplo, risco de epidemia, morte sem assistência médica etc.).

\section{(c) DESTINO DADO AO ASSUNTO}

Quanto ao destino, foram classificados em:

(1) descartado: a análise das atas permitiu concluir que o destino dado ao assunto foi no sentido de descartá-lo. Os descartados não adquiriram status de assuntos de agenda. Constituiram relatos, informes, desabafos etc., que não foram incorporados ao processo politico em questão;

(2) permanece na agenda: o assunto não é descartado mas, apesar de ficar na agenda e, portanto, ser considerado importante, não é priorizado. Não são desprezados mas o processo político mostra-se impotente para o 
seu encaminhamento. Podem sair da agenda, serem remetidos a outros processos políticos ou ficar latentes, mas não são implementados;

(3) priorizado: o assunto não é apenas considerado importante, e é priorizado. Buscam-se as condições para a sua implementação ou encaminhamento no âmbito do processo politico que ocorre no próprio CMS

ASPECTOS OPERACIONAIS DE ANÁLISE DAS ATAS DOS CONSELHOS LOCAIS DE SAÚDE

É importante ressaltar a dificuldade de dar uniformidade a assuntos nem sempre bem formulados e em atas habitualmente pouco claras, como foram, às vezes, as desses conselhos. A opção de classificação dos assuntos nos grupos acima foi realizada após diversas leituras das atas

Estes assuntos foram classificados nos seguintes grupos:

(1) regimentais: relativos à discussāo do regimento interno, à presença ou ausência de conselheiros, quórum; exclusão e reintegração de conselheiros etc;

(2) relacionados à divulgação de informações aos conselheiros/usuários: nesse grupo foram incluidos todos os assuntos que têm como foco o conselheiro/usuário. O conselheiro usuário é o sujeito-passivo. Ele recebe o assunto. Dizem respeito a informações sobre prevenção de doenças, divulgação da realização de conferências ou pré-conferências de saúde, divulgação de cursos ou medidas que visam capacitação de conselheiros de saúde etc:;

(3) relacionados a sugestões dos conselheiros/usuários aos outros membros do CLS: referem-se aos assuntos em que o conselheiro/usuário é um sujeito-ativo. Ele traz o assunto; 
(4) reclamações relacionadas à UBS: nesse grupo foram incluídas todas as reclamações que dizem respeito à infra-estrutura física e de recursos humanos da UBS. Incluem-se nesse grupo reclamações sobre falta de insumos, equipamentos e ineficiência de processos;

(5) reclamações relacionadas à demanda reprimida na assistência básica e especializada: todas as queixas e reclamações referentes à dificuldades de demanda, como falta de oferta de consultas médicas, odontológicas, existência de filas etc.;

(6) justificativa dos gestores (locais ou municipais) às reclamacoes dos conselheiros/usuários. Nesse grupo foram incluidos assuntos que entravam na pauta do CLS como conseqüência de reclamações constantes dos itens (4) e (5). Por exemplo: os gestores locais informam que se ampliou o número de recursos humanos ou que for realizado determinado investimento na UBS;

(7) ligados à desmotivação dos conselheiros. Incluem todos os assuntos em que o foco da discussão era a desmotivação e a impotência dıante dos problemas;

(8) relacionados à mobilização da população para solução de problemas do bairro (mutirões). São exemplos deste grupo: mobilização para doação de sangue, mobilização para coleta de medicamentos não-vencidos etc.;

(9) estudo de clientela e ligados a mudanças do modelo gerencial e assistencial. Incluem-se neste grupo estudos epidemiológicos da área, reflexões sobre modelo de saúde etc. 


\section{CAPÍTULO 4}

\section{O PROCESSO DE MUNiCiPALIZAÇÃo dA SAÚdE DE MARÍLIA-SP}

\subsection{Considerações iniciais}

As razões da escolha do municipio de Marilia, Estado de São Paulo, para a investigação empirıca coram citadas no capítulo 3. A técnica metodológica, também já referida nesse capitulo, teve como objetivo principal conhecer o processo decisório local, pressupondo que o sistema de decisões das politicas locais de saúde, categoria empirica central, é constituido de processos politicos distintos, com diferentes graus de importância e visibilidade. Procurou-se compreender esses processos a partir dos dados obtidos com as pesquisas de documentos e entrevistas com os atores relevantes.

A coleta de dados procurou abranger todo o processo de municipalização da saúde em Marilia, desde o seu início, ocorrido nos primeiros anos da década de 1980, até o final de 1999, periodo em que se encerrou a coleta. Os anos que corresponderam à análise foram divididos em periodos correspondentes às diferentes gestões municipais: (1) início da década de 1980 até 1988; (2) 1989 - 1992; (3) 1993 - 1996 e (4) 1997 1999. A pesquisa documental utilizou-se de fontes primárias diretas e indiretas (livros de atas dos conselhos de saúde, planos de saúde, documentos relativos à legislação local da saúde etc.). A escolha dos atores locais relevantes teve como critério sua inserção no processo de municipalização, tendo sido incluidos governantes locais (prefeito, secretário de saúde e assessores), lideranças comunitárias e outras lideranças do setor saúdie. 
A relevância dos atores locais para o sistema de decisões das políticas de saúde não foi uniforme ao longo do processo de municipalização, variando conforme o período considerado. Para facilitar sua identificação utilizou-se a inserção e a influência que os personagens ligados à saúde exerceram no sistema politico local. A Figura 3 traz um esquema de sistema político que contribui para tornar mais clara a identificação desses atores.

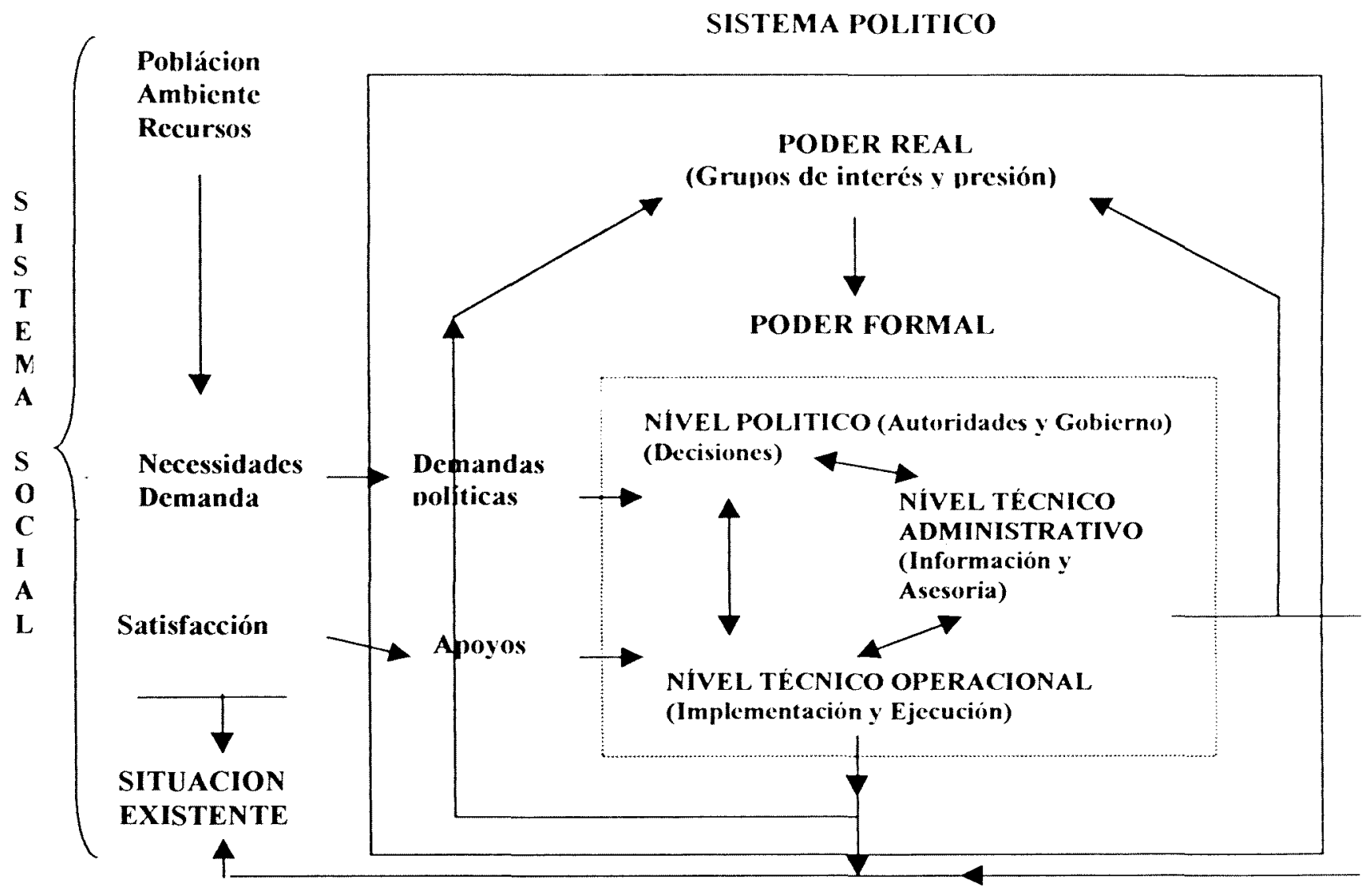

Figura 3 - Esquema do sistema políptico e seu vínculo com o sistema social. (reproduzida do texto OPS/CLPAS. Formulacion de politicas de salud. OPS/Centro Latinoamericano de Planificacion Social, Washington DC, 1975).

Nessa figura, o poder político do Estado é representado pelo Poder Formal. O Estado atua em um meio social em que estão presentes diversas cutras estruturas e componentes (classes sociais, grupos e indivíduos) que também influem nas decisões politicas. O conjunto dessas influências 
constitui outra forma de expressão de poder político, chamada Poder Real. No meio social, os indivíduos e os grupos sociais atuam politicamente quando suas decisões e ações geram demandas politicas. Esses indivíduos e grupos podem, portanto, transformar as insatisfaçōes sociais em demandas políticas.

Esse enfoque tem, de acordo com seus autores, limitações que devem ser consideradas quando de sua utilização. A propósito é importante referir a seguinte referência: "El enfoque sistemico debe ser complementado com los análises de estructuras y funciones especificas (funcionalestructural) y de la evoluoon histórica de los componentes y relaciones fundamentales (histórıco-esiructural), como marco explicativo de los comportamientos individuales y colectivos. En este trabajo no se discuten los diversos enfoques mencionados excepto las caracteristicas generales del análisis sistêmico incluidos en la descriptión que se hace de un sistema político." (OPAS 1975 , p 15)

Apesar de suas limıtações como fonte exclusiva para análise do processo político, esse esquema mostra-se útil para identificar os atores relevantes. Utilizando-o, identificamos três grandes grupos:

1. os governantes locais;

2. os atores componentes do poder real, que podem exercer pressão ou influência no poder formal;

3. as demandas e necessidades oriundas do sistema social.

Os governantes locais, personalizados na figura do prefeito, do secretário de saúde e dos seus principais assessores, foram considerados "atores relevantes" em todos os periodos analisados, já que, como componentes do poder formal detiveram, inegavelmente, algum poder político local no sistema de decisões das políticas de saúde, sempre que estiveram no governo. 
Os atores do poder real tiveram sua relevância variável ao longo dos quatro períodos analisados. Um dos atores desse grupo que se mostrou relevante em todos os períodos recebeu a designação de aliados do movimento sanitário. Logo mais à frente discorreremos sobre os aliados do movimento sanitário, para melhor caracterizá-los. Outros mostraram-se mais claramente relevantes no sistema de decisões em apenas alguns dos periodos, por causa do contexto local, tais como o Conselho Municipal de Saúde, os Conselhos Locais de Saúde e os prestadores de serviço (donos de hospitais, por exemplo). Além desses, que adquiriram maır visibilidade, outros atores e outros fatores de influência nas decisð̌es tomadas também surgiram na análise, sob a forma de produtos do estudo empirico, como se verá ao longo deste capítulo. 


\subsection{Década de 1980 até 1988}

O processo de municipalização da saúde em Marilia teve inicio nos primeiros anos da década de 1980, estimulado, principalmente, por dois fatores: os propósitos descentralizantes do governo estadual da época (governo Montoro) e o advento das Ações Integradas de Saúde - AIS - em 1984. Até esse periodo, o município tinha três estruturas de serviço público ambulatorial distintas: (1) a federal, constituída por uma unidade ambulatorial prestadora de serviços básicos e especializados (o Posto de Assistência Médica - PAM - do Instituto Nacional de Assistência Médica da Previdência Social - INAMPS) e um serviço de controle dos prestadores privados conveniados e contratados; (2) a estadual, representada por uma unidade ambulatorial - o tipico Centro de Saúde Estadual - presente na maioria das cıdades de médio e grande porte, na época, e (3) o Centro de Saúde Escola (CS Escola), gerenciado pela Faculdade de Medicina local.

De acordo com CHIRELLI ${ }^{30}$ (1995, p. 48), em Marilia, em 1983, os serviços federais (próprios e contratados) eram responsáveis por $66 \%$, e o Governo do Estado, em seu Centro de Saúde, por 14\% dos atendimentos ambulatoriais. O CS Escola e o Hospital da Faculdade de Medicina realizavam os restantes $20 \%$ dos atendimentos.

No modelo vigente na época, devendo-se lembrar que era anterior às Ações Integradas de Saúde, correspondente à década de 1970 e ao início dos anos 80 , já comentado no capítulo 1, era evidente a falta de integração entre os seus componentes. O poder de formular e dar direção às politicas de saúde era centralizado e, além disso, disperso em dois pólos distintos: a União, responsável pela assistência médica previdenciária, coordenada pelo INAMPS, e os governos estaduais, por intermédio das secretarias estaduais de saúde, pelas ações no chamado campo preventivo. 
Em Marília, como ocorreu em vários municipios brasileiros que tinham escolas médicas com departamentos de medicina preventiva mais atuantes e inovadores, a Faculdade de Medicina de Marília - FAMEMA - contribuiu, com a criação do CS Escola, para romper parcialmente com a dicotomia existente entre os serviços previdenciários federais, responsáveis pela atenção curativa, e os serviços estaduais, pelas de caráter preventivo. Essa unidade tinha como principal objetivo propiciar a integração docenteassistencial, promovendo a interação dos alunos com a rede de atenção primária à saúde.

O SURGIMENTO E A EXPANSÃO DA REDE DE POSTOS E CENTROS DE SAÚDE DO MUNICIPIO

No ano de 1983, Marília aderiu ao "Convênio do Municipio Carente" do Governo do Estado, que tinha como finalidade contribuir com a ampliação dos equipamentos públicos municipais para o atendimento às áreas sociais. Essa adesão foi um dos fatores que contribuiu para o surgimento da rede de serviços ambulatoriais de saúde no municipio.

No ano seguinte, com a assinatura do convênio das Ações Integradas de Saúde, a expansão da rede de atenção primária à saúde se consolidou. O surgimento e a expansão da rede municipal de unidades básicas de saúde ocorreu, portanto, como citamos, em contexto no qual estavam bem evidentes a política com aspectos descentralizantes do governo estadual e, de forma especial, a implementação das AIS, etapa da Reforma Sanitária que antecedeu a implantação do Sistema Único de Saúde, já analisada no capítulo 1.

O prefeito de então, do PMDB, cria a Secretaria Municipal de Saúde e estimula a expansão da rede de atenção primária, firmando parceria com a Faculdade de Medicina local. Até o final de 1983 são inauguradas três novas unidades básicas de saúde (UBS) na área urbana e duas na área rural. Nos anos seguintes, até o final de 1988, inauguram-se mais sete UBS urbanas e 
quatro rurais, passando a contar o município, no final desse período, com 17 UBS, incluido o CS Escola.

\section{A "ESTADUALIZAÇÃO" DA SAÚDE EM MARÍLIA}

A influência dos atores locais no direcionamento das politicas de saúde, até essa época, era bastante reduzida. Os "atores fortes" da saúde eram os governos faderal e estadual, que tinham o controle sobre a maior parte da capacidade instalada, ambulatorial e hospitalar. A descentralização, apesar de ampliar timidamente o espaço de poder municipa: fortalecia de fato os governos estaduais através da chamada "estadualızáw" da saúde. No período AIS/SUDS, de 1984 a 1988, as secretarias esiaduais de saúde assumiram diversas funções do governo federal.

No Estado de São Paulo, a reforma administratıva ocorrida na Secretaria Estadual de Saúde, em 1986, com a criação dos escritórios regionais de saúde - ERSAs - que incorporaram as atividades do INAMPS, tornou os diretores desses órgãos personagens influentes na formulação das politicas municipais de saúde. A ampliação dos recursos federais que passaram a ser colocados à disposição do governo do Estado e o poder de influir nas formas pelas quais se daria sua liberação aos municipios, que a Secretaria Estadual de Saúde e os ERSAS passaram a ter, interferiram nas características da expansão das redes municipais de saúde.

As reuniões da CIMS (Comissão Interinstitucional Municipal de Saúde) eram realizadas no ERSA, sendo coordenadas pelos gestores estaduais. A POI (Programação e Orçamentação Integrada) tinha grande peso dos órgãos estaduais em sua elaboração. Na definição do plano de aplicação dos recursos, $70 \%$ tinham como fonte as transferências federais do SUDS, repassadas ao município pelo governo do Estado, enquanto o municipio se encarregava de suprir os outros $30 \%$. 
Em Marilia, nessa época, apenas 4 a $5 \%$ do orçamento municifral era destinado à saúde. Como as responsabilidades assumidas pelo município na área da saúde eram muitas, a dependência dos recursos federais transferidos pelo governo estadual era, portanto, bastante expressiva.

A gradativa desconcentração de responsabilidades, da União para os estados, e destes nara os municipios, constituía um movimento inexorável. Os municipios que discordassem do processo poderiam, no máximo, retardá-lo. Este não foi o caso de Marilia. O municipio aderiu à descentralização coordenada pelo governo estadual, e passou a assumir rapidamente o gerenciamento da atenção básica, como se verá a seguir

OS GOVERNANTES LOCAIS E OS ALIADOS DO MOVIMENTO SANITÁRIO

A presença de aliados da Reforma Sanitária nos municipios, como tem mostrado diversos estudos de caso, constitui um fator positivo para a implementação das politıcas de descentralização. Tudo indica que a municipalização da saúde depende de uma "militância política" para impulsionar o processo. Quando essa militância não existe ou não consegue ocupar espaços nos fóruns decisórios, o processo anda mais devagar e, muitas vezes, toma rumos diferentes dos pretendidos pelo "Movimento Sanitário". Esse movimento, como afirma SILVA JÚNIOR ${ }^{107}$ (1998, p.22-23), citando Donnangelo e Campos, Teixeira, Escorel, Arouca, e Paim, entre outros, constitui o campo politıco da reforma da saúde. Uma das condições para que haja "reforma" é a adesão de atores locais que atuam nesse campo. Não bastam mudanças administrativas e transferências de responsabilidades, impostas de "cima para baixo".

O movimento sanitário tinha "aliados" em Marilia. Vamos designar esse grupo como aliados do movimento sanitário. Era constituído, em sua maioria, de pessoas oriundas da Faculdade de Medicina, na qual assumiram posições de destaque, e de outras instituições da área de saúde, tais como 
as instâncias regionais da Secretaria Estadual de Saúde (DRS, DIR, ERSA) e da Secretaria Municipal de Saúde, entre outras. A designação dada a esse grupo, "aliados do movimento sanitário", não significa, porém, que outros atores locais não tenham também se comportado como aliados da reforma. Os que estão sendo convencionalmente denominados dessa forma, no entanto, têm ligação mais orgânica com este movimento e são, portanto, mais identificados com o seu projeto politico.

Alguns desses personagens foram atores relevantes da reforma sanitária também fora do àmbito local. Ou seja, além de contribuirem para a implementação da descentralização da saúde no municipio, participaram de articulações nacionais e estaduais favoráveis à reforma. Sua atuação no processo decisório local será assinalada em vários momentos ao longo deste capitulo, e mesmo que esse grupo de pessoas não tenha adotado os mesmos posicionamentos políticos ao longo de todo o processo de descentralização e municipalização da saúde, discordando, às vezes, entre si, tinham uma caracteristica comum: eram todos partidários da Reforma Sanitária.

A posse de nova administração municipal, em 1983, ocorre em contexto no qual os aliados do movimento sanitário passaram a exercer forte influência junto aos governantes - prefeito e secretário de saúde - que assumiram. O prefeito empossado escolhe um secretário de saúde que se mantém durante todo o periodo de governo bem articulado com 0 movimento sanitário. Essa aliança é perceptivel nas manifestações de diversos entrevistados e algumas delas reproduzimos a seguir:

Essa idéia (de criar uma rede municipal de postos e centros de saúde) surgiu... assim ... tinha um prefeito, que é o atual prefeito, que na época considerava importante descentralizar o acesso da população aos serviços de saúde. Isso era uma coisa forte para ele. E na época ele autorizou, ou fez uma discussão na campanha dele, que coincide com as AIS, e designou a preventiva da Faculdade para fazer um projeto nesse sentido. De criação de outras Unidades Básicas de Saúde. Foi quando deu um “boom" nas Unidades Básicas. A gente tinha ... não sei exatamente o 
número ... três, quatro, no máximo, e sai fazendo mais unidades (Gestor 6) ${ }^{1}$.

A criação da Secretaria de Saúde foi uma pressão do pessoal envolvido na área de saúde ... na época (refere-se aos nomes de alguns aliados do movimento sanitário). Foi uma promessa de campanha, que depois foi cumprida pelo atual prefeito (Gestor 2).

(Porque) eu não tinha uma boa formação na área de saúde pública. Mas na época tinha (refere-se aos nomes de alguns aliados do movimento sanitário). Então, para assumir, eu fiz um pacto, eu seria o Secretário de fato mas todos teriam uma participação. E a descentralização foi tão bem feita ... e tinha, em todos os níveis, as condições necessárias... (Gestor 2).

Eu fui para a Secretaria de Saúde com o apm da Faculdade de Medicina. Com o apoio da Secretaria (estadual) de Saúde. Então, houve uma integração realmente em todos os sentidos. 1. o Prefeito ... ele era jovem ... mas ele sentia necessidade de descentralizar (Gestor 2).

Os governantes locais, particularmente o prefeito, apesar de reconhecerem e legitimarem o projeto dos alıados da reforma, tinham, obviamente, percepção própria do processo de oescentralização da saúde. Para analisar a interação que se estabeleceu entre esses dois grupos de atores - governantes locais e aliados da reforma sanitária - é necessário considerar seus distintos projetos políticos e suas diferentes racionalidades na interpretação do significado da municipalizaçāo da saúde. Para os aliados da reforma sanitária ela seria uma das diretrizes estratégicas de reforma da saúde. E para o prefeito? Uma de suas manifestações permite inferir elementos de sua racionalidade:

As filas concentradas em um único Centro de Saúde ... a reclamação do povo. Eu era vereador, muito jovem, e na campanha (para prefeito) as mulheres, as senhoras, as gestantes, falavam assim: "você vai se eleger, mas não pode ter esta fila que tem". Então isso foi uma constatação. E a partir daquela constatação nós nos reunimos ... com uma turma de gabarito, de bons profissionais ... e pontuamos algumas regiões onde havia uma demanda grande. $\mathrm{E}$ abrimos ali as Unidades Básicas de Saúde ... (Gestor 1). 
Sobressaem, nessa "racionalidade do governante", os problemas que devem ser resolvidos. É a "reclamação do povo". Mesmo que tenham consciência de que projetos setoriais reformistas podem dar bons resultados futuros, de mais longo prazo, os políticos freqüentemente consideram tempos menos elásticos para tomar decisões. O politico trabalha com valores de reconhecimento da população, aprovação da opinião pública, aumento de sua governabilidade e atendimento aos seus critérios de sensibilidade social $O$ comportamento político dos governantes são influenciados por valores como esses. Ou seja, mesmo legitimando um projeto técnico, sempre existe um projeto político por trás da ação do governante é é es pue predomina.

Os aliados do movimento sanitário, por outro lado, têm, ou é desejável que tenham, uma imagem-objetivo projetada para um futuro situado um pouco mais à frente Para esses atores, a expansão da rede básica é uma etapa em um processo de intervenção mais amplo, que faz parte da descentralização da saúde, uma das diretrizes do SUS.

Essas diferenças na percepção sobre o significado das mudanças que ocorriam no sistema de saúde, no periodo que estamos analisando, estão sendo ressaltadas para mostrar que os interesses dos governantes e dos aliados do movimento sanitário, apesar de confluentes, eram distintos. Isso, porém, em nenhum momento fragilizou a aliança que se estabeleceu entre eles. As alianças são mais facilmente rompidas quando existe frágil identificação de interesses no processo de interação politica dos atores. Não foi o que ocorreu nesse caso. Os governantes locais e os aliados da reforma sanitária estabeleceram forte aliança. Estabeleceu-se processo permanente de negociação entre os dois grupos, que resultou em freqüentes mecanismos de troca. De um lado, o governo local assumia a descentralização da saúde como um projeto da reforma sanitária. De outro, os instrumentos de poder institucional que os aliados do movimento sanitário detinham foram disponibilizados para os governantes locais. Isso se 
traduziu, concretamente, em acordos operacionais, que atendiam aos dois lados, como mostram os depoimentos transcritos a seguir:

Os funcionários eram da Fundação, tudo da Faculdade. Mas seguiam os programas da Secretaria. Naquela época o município estava muito acanhado. Mas, em parceria, o município alugava a casa, comprava os equipamentos e a gente entrava com os recursos humanos e o gerenciamento. Isso durou até 84,85 . (Gestor 6).

O município de Marilia tem a linha férrea ... então a coisa era assim, para baixo da linha é de um e para cima é de outro. Quando eu entrei na Faculdade, em 82, nós só tínhamos o CS Escola. De 82 a 84 a gente assumiu 40\% do município (Gestor 6).

A Faculdade assumiu boa parte do gerenciamento da reoe de unidades de saúde do municipio e cedeu os recursos humanos necessários para o seu funcionamento. Essa aliança contribuiu para expandir rapidamente a rede básica e ampliar a extensão da cobertura assıstencial ambulatorial.

O resultado dessas modificações no sistema de saúde municıpal foi mais condizente com os interesses dos governantes locais ou do movimento sanitário?

Nesse periodo, de acordo com CHIRELLI ${ }^{30}$ (1995), o poder "politico" sobrepunha-se ao poder de normatização técnica e administrativa. Reafirmando esse fato, Chirelli argumentou que a expansão da rede de UBS teve como principal preocupação a extensão da cobertura assistencial e pouca preocupação com a qualidade dos serviços oferecidos. Essa posição é reforçada pela opinião de alguns entrevistados:

Naquele momento (o crescimento da rede de unidades de saúde estava) pouco preocupado com a qualidade. Nem dava. Mas preocupado com a quantidade. Com a coisa do acesso. E fez um monte de Unidades ... (Gestor 6). 
Olha, o nosso Prefeito ... a gente até brinca: pra ser Secretário do Camarinha tem que ser extremamente político. Então, é claro, a gente contra-argumentava. Se achasse que aquela área não era adequada ... Mas era promessa, não é. E o PMDB já vinha com esse discurso de descentralização na área da saúde. Foi Montoro, Quércia ... (Gestor 2).

Então nós abríamos postos de saúde em casas mesmo, ... Bandeirantes, Coimbra, JK ... hoje são postos de saúde com estrutura boa, mas que no começo eram pequenos. E a gente sabia, na época, que aquilo ia ser melhorado no futuro (Gestor 2).

Contrataram funcionários ... foi num crescente. E, na época, a gente tinha dificuldades na qualificação do pessoal. Mas atendia o Prefeito. A gente sabia que la na frente essa coisa iria melhorar (Gestor 2).

Inegavelmente o fator determinante da expansão da rede de unidades de saúde foı a demanda reprimida na área de atenção básica. Essa expansão, como afirmou Chirelli e de acordo com a percepção de entrevistados clados acima, que se referiram ao assunto, não foi acompanhada do devido planejamento que possibilitasse aumentar a oferta assistencial e ao mesmo tempo incorporar mudanças no modelo de atenção vigente.

\section{OS OUTROS ATORES LOCAIS}

A influência no processo decisório local não se estendeu, nesse período, além dos governantes locais e dos aliados do movimento sanitário Os outros atores locais com potencial interesse nas politicas de saúde, tais como os prestadores de serviço, os grupos de usuários organizados e os profissionais de saúde, não tiveram participação significativa nos processos politicos locais.

Sua influência, se houve, deu-se a partir de demandas dirigidas diretamente ao poder formal, personalizado na figura do prefeito ou do secretário de saúde. É necessário ressaltar que optamos por não analisar o papel da CIMS (Comissão Interinstitucional Municipal de Saúde), que pode ser considerado o "embriāo" do Conselho Municipal de Saúde, em virtude 
deste fórum não ter sido considerado relevante no sistema de decisões, segundo a manifestação de diversos entrevistados.

\section{O FORTALECIMENTO DO PROCESSO DE MUNICIPALIZAÇÃO}

O surgimento de uma rede municipal de unidades básicas de saúde não foi acompanhado da reorganização dos serviços existentes. A integração entre os diferentes serviços e os niveis de atenção era ainda incipiente e a gestão da saúde estava dispersa em diferentes comandos e com pouco controle público

Em 26 de janeiro de 1988 por intermédio da Lei n. ${ }^{0} 3.286$ (MARÍLIA ${ }^{67}$, 1988), manifesta-se a intenção de "Municipalização dos serviços de saúde pública", através de convênios com o governo estadual.

Seu artigo $1^{\circ} \mathrm{diz}$ :

Fica o Municipio de Marilia autorizado a celebrar, representado pelo seu Prefeito em exercicio, convénio com o Governo do Estado de São Paulo, com interveniência da Secretaria de Estado da Saúde, objetivando implementar a integração dos serviços de saúde que atuam no Municipio, propiciando mudança qualitativa dos serviços e fortalecimento do processo de municipalização.

Essa lei inaugura novo momento da municipalização da saúde em Marília. Se até essa época a prioridade tinha sido criar e fortalecer uma rede de serviços ambulatoriais de atenção primária, em parceria com a Faculdade local, a partir dessa data começa a entrar em pauta a necessidade de integração mais efetiva dos serviços públicos de saúde. Essas mudanças são influenciadas pela aprovação das diretrizes do SUS, na VIII Conferência Nacional de Saúde, em 1986, ocasião em que, entre outras medidas, o movimento da reforma da saúde propõe a integração dos serviços como etapa preliminar à constituição de um comando único nos diferentes niveis de governo. 


\subsection{Período de 1989 a 1992}

A administração municipal eleita para esse periodo teve, durante 0 processo eleitoral, apoio do grupo politico que deixou o governo. Esses grupos, porém, romperam já no ano seguinte à posse. O rompimento fragilizou a aliança que existia até então entre os governantes locais e os aliados do movimento sanitário. Os dois grupos, no entanto, mesmo assim continuaram a ter papel relevante no novo contexto, como veremos a seguir.

\subsubsection{Os governantes locais e os aliados do movimento sanitário: percepções, interesses e contexto}

No período de 1989 a 1992 deixou de existir identificação de interesses entre os governantes locais e os aliados do movimento sanitário. Rompeu-se a aliança política entre os dois grupos. Um deles passou a ter postura mais independente que a do outro, passando a verificar-se disputa de poder entre ambos. Além disso, os governos municipal e estadual deixaram também de compor a aliança que caracterizava o período anterior.

Nesse contexto, qual era a percepção destes dois grupos de atores sobre o processo de municipalização da saúde que, apesar de ainda no início, estava em pleno curso?

O que se pode destacar a respeito desse assunto é o seguinte:

1. Os governantes locais tinham a intenção de realizar uma "gestão técnica". Isso era reconhecido pelos aliados do movimento sanitário e destacado como fator positivo.

2. A centralização promovida pelo Prefeito dificultava as ações da Secretária de Saúde e reduzia acentuadamente a sua autonomia. 
O relato que se segue é representativo desses destaques:

$\mathrm{Na}$ gestão (desse período) foi uma coisa interessante. A Secretária fez uma gestão bem técnica. Ela se assessorou tecnicamente e delegou. Mas, como ela não tinha o poder de compra, o poder do recurso, teve dificuldade de implementar. Eu acho que ela teria implementado mais, caso tivesse essa possibilidade. Eu acho que ela era barrada na Prefeitura. Por mais que quisesse implementar. Eu me lembro que estava na DIR e negociei com (com a Secretaria Municipal de Saúde) o projeto do Aedes. (programa de erradicação do mosquito Aedes). Para você contratar os agentes ... essa era uma proposta forte na Secretaria (...) a dificuldade que a gente teve de implementar isso (foi enorme). E era menos por não acreditar e sim pela dificuldade mesmo ... uma coisa muito centralizada. Um prefeito extremamente centralizador (Gestor 6).

3. A disputa de poder entre os dois grupos levou os governantes locais a procurarem delimitar mais claramente seus espaços de atuação.

O depoimento que transcrevemos ressalta esse fato:

Uma das coisas que me chamou a atenção foi a seguinte: o grupo defensor da municipalização (...) esse grupo na época estava na Regional. Eles não quiseram descentralizar. Porque quando tem outro (grupo) na municipalização (não thes interessa descentralizar). Porque? Eles não queriam perder o poder. É isso que eu senti. Não sei. Não foi uma coisa clara, lógico. Por exemplo: existia na época a CIMS. Sabe onde eram feitas as reuniões? Na Regional. E quem era o Diretor? Era uma pessoa super municipalista, certo! Defensor mesmo. De carteirinha. Na DIR. Na Regional. E pra eu tirar de lá. Tive que fazer um esforço (...) Entendeu. Então foi muito difícil (Gestor 3).

A participação dos aliados do movimento sanitário no jogo político disputando espaços locais de poder institucional, conforme ressaltou o último depoimento, nos mostra que a ação política desses atores não é influenciada apenas pelos interesses da Reforma Sanitária. Interesses pessoais ou grupais podem prevalecer, apesar de que não temos elementos suficientes para analisar se isso ocorreu em Marilia. Seria, porém, ingenuidade considerar que esses atores se comportam, em todas as situações, apenas, como "braços políticos" da Reforma Sanitária. 
As divergências que ocorreram entre os grupos citados não foram aparentemente muito marcantes, não chegando a interferir nas mudanças no sistema de saúde. Nesse periodo investiu-se na melhoria da estrutura física das UBS e na ampliação dos serviços assistenciais. Reduziu-se gradativamente a dependência do ERSA e, segundo dados de CHIRELLI ${ }^{30}$ (1995, p.67), houve substancial aumento de recursos humanos. O número de médicos, por exemplo, passou de 28, em 1989, para 58, em 1992.

A municipalizaçāo prosseguiu, avançou, ampliando significativamente a produção de serviços nas áreas médica, odontológica e de enfermagem. As UBS começaram a consolidar-se como porta de entrada do sistema público de saúde. Essas modificaçōes traduziam-se, fundamentalmente, em ampliação da cobertura assistencial, como no periodo anterior. A diferença é que agora ocorriam numa rede melhor estruturada.

A partir de 1990 passou a ocorrer redução do repasse de recursos federais para a saúde, fato que ocasionou dependência progressivamente maior do tesouro municipal para o custeio da rede assistencial. Isso gerou conflitos entre a prefeitura e os governos federal e estadual. Os governantes municipais consideravam que os encargos $\mathrm{e}$ as responsabilidades que estavam assumindo não eram acompanhados pela devida contrapartida de recursos. Pode-se compreender melhor a origem desse conflito analisando os dados de CHIRELLI ${ }^{30}$ (1995), os quais evidenciam que o orçamento municipal da saúde, de 1987 a 1989, era coberto em $70 \%$ pelos recursos federais, transferidos pelo governo do estado para o municipio. Em 1990, esse porcentual passa a ser de apenas $20 \%$. O Prefeito se sentiu enganado porque sua expectativa, quando municipalizou, era de que fossem mantidos os mesmos aportes de recursos não-municipais, o que não se verificou. Essa situação mostra que no discurso preconizava-se descentralização de poder mas, na prática, estava ocorrendo apenas uma desconcentração de responsabilidades para os municipios. 
Essa situação foi interpretada pelos governantes locais como duplamente adversa: por um lado, o municipio era obrigado a executar o que determinava o governo do Estado, já que a sua capacidade de modificar o movimento descentralizatório da política de saúde era bastante limitado; por outro, passava a contar com aporte de recursos progressivamente menor; ampliando ainda mais as dificuldades de custeio da rede própria, o município teve que assumir quatro das seis UBS que estavam sob a gerência da Faculdade de Medicina. Alem disso, ocorreu mudança nos critérios de repasse, que passaram a basear-se na produção realizada e não mais por projetos. As conseqüências dessa mudança para o sistema de saude foram marcantes. A lógica de financiamento forçava a produção de atos curativos. Os serviços públicos tinham que "faturar", atendendo a doença reforçando, com isso, o modelo de saúde clínico-curativo tradicional Os serviços privados, pouco controlados pelo poder público, reduziam a oferta de alguns atos médicos e aumentavam o número de outros, selecionando a oferta $e$ direcionando-a para os atos cujos valores de remuneração eram maıres

Nesse contexto, em que as dificuldades de financiamento estavam bem evidenciadas, é realizada a I Conferência Municipal de Saúde de Marilia, em 1991 (MARILIA $^{70}$, 1991). A conferência de abertura "Saúde: municipalização é o caminho", que seria o tema da IX Conferência Nacional de Saúde, marcada para o ano seguinte, mostrava que, apesar das dificuldades conjunturais, o movimento sanitário estava presente no municipio. Os aliados desse movimento consideravam que a municipalização da saúde era a estratégia principal para superar as dificuldades

Aparentemente todos os atores locais, e não apenas os aliados do movimento sanitário, apoiavam a municipalização. Eventuais interesses discordantes não foram consubstanciados em ações politicas efetivas que dificultassem a descentralização. Exemplo desses interesses discordantes, que significou uma manifestação de receio e contrariedade à 
municipalização, foi a posição adotada por segmentos da categoria médica local, que viam no crescimento da municipalização uma das causas de sua "baixa" remuneração como autônomos, como ilustram os depoimentos que transcrevemos a seguir:

(...) a classe médica, por exemplo. A discussão com a classe médica, em dado momento foi muito difícil, porque a acusação era a seguinte: o SUS só dá certo aqui em Marilia. Nós estamos empobrecendo porque aqui (refere-se a alguns atores que defendem a Reforma Sanitária no municipio) são os culpados dessa coisa.

(isto se manifestava) verbalmente. Em assembléias, na questão da Unimed.

Não gerava boicote mas gerava ação política. Na cidade mesmo. Brigas na Secretaria ... por cargos na Regional ... tem esse grupo ai de malucos ... eles querem acabar com as diferenças, enfim (Prestador 4 ).

Há, sim. Aqui em Marilia, quando cheguei aqui, tinha um comentário muito comum que dizia que a Medicina tinha sido socializada. E eu dizia: mas gente! Socializou aonde? Isso era tão freqüente que quando eu perguntava para os alunos a respeito lá do artigo 199, que dava os direitos da iniciativa privada eles diziam: Não! Foi socializada. Por que eles ouviam isso de todos os professores. A corporação, (...) eles se protegem. Eles vêem o SUS como coisa assim da caridade. Não do Inamps, mas da caridade. Por que (na época) do Inamps (visualizam usuários) que podiam exigir,... que tinham certos direitos, ... podiam denunciar. Na caridade eu espero humildade. Recebem um equipamento SUS e usam para atender a clientela particular. Por exemplo, a Santa Casa fez muito isso. $O$ corporativismo fala mais alto. É difícil enfrentar médico. E médico enfrentar médico mais difícil ainda. E não deve ser na "porrada". Quer dizer, ninguém vai fazer reforma sanitária sem médicos. Eles são fundamentais. Mas se deixar, eles vão exigir todas as concessões possíveis (Profissional de saúde 2).

A I Conferência Municipal de Saúde de Marilia contribuiu para a elaboração do Plano Municipal de Saúde (PMS), de 1992. Esse Plano contemplou basicamente a melhoria no controle de doenças (raiva, AIDS, cólera, dengue etc.) e o monitoramento de óbitos infantis (MARÍLIA ${ }^{71}$, 1992).

Os PMS constituem-se habitualmente em manifestações de intenção difíceis de se transformar em realidade. Trata-se de uma obrigação legal, um requisito a ser cumprido, e raras vezes são elaborados como "Planos de 
Ação" verdadeiramente viáveis. Em Marilia isso parece não ter sido diferente, devido sobretudo à reduzida autonomia dos governantes para formular e implementar políticas. As principais decisões não eram tomadas no âmbito do poder local, mas fora do município. Os governantes locais tinham um campo restrito de formulação de políticas, como se verá a seguir, com a análise das atas do Conselho Municipal de Saúde.

\subsubsection{O surgimento do Conselho Municipal de Saúde}

A le. complementar $n .^{\circ} 02$, de 14 de dezembro de 1.990 , regulamentou o Conselho Municipal de Saúde (CMS) (MARÍLIA $\left.{ }^{68}, 1990\right)$. Por essa le ficam estabelecidos, entre outros, alguns aspectos ligados ao CMS (1) É o órgão colegiado máximo da política municipal de saúde, tendo funções de caráter deliberativo, normativo, fiscalizador e consultivo; (2) compete-Ihe atuar na formulação da estratégia e no controle da execução da politica municıpal de saúde e (3) tem a responsabilidade pela aplicação das diretrizes a serem observadas na elaboração dos planos de saúde, em função das características epidemiológicas e da ordenação dos serviços.

De acordo com a lei que regulamentou seu funcionamento, o CMS passou a ser composto dos seguintes membros:

1 - Administração Pública:

a) dois representantes do Poder Executivo, sendo membro nato o Secretário Municipal de Saúde;

b) dois representantes do Poder Legislativo;

c) dois representantes da área de saúde do governo estadual;

II - Entidades de prestação de serviços na área da saúde, com cadastro na Prefeitura Municipal de Marília:

a) dois representantes de entidade hospitalar sem fins lucrativos;

b) um representante de instituição de saúde privada;

c) um representante de entidades representativas da classe médica;

d) um representante de entidades profissionais de enfermagem, psicologia, odontologia ou serviço social;

e) um representante de associações ou sindicatos de funcionários públicos não-universitários da área da saúde

III- Usuários: 
a) um representante do Sindicato dos Trabalhadores Rurais;

b) um representante dos Sindicatos dos Trabalhadores na Indústria, comércio ou transportes;

c) um representante de sindicatos patronais;

d) quatro representantes de conselhos de comunidades de saúde, sendo um por região da cidade ou, na falta desses, de associações de bairros;

e) um representante de clubes de serviços, entidades religiosas ou demais associações da área da saúde;

f) um representante de associações de doentes, deficientes físicos ou mentais;

g) três representantes de centros comunitários, associações de moradores ou associações de amigos de bairro.

Essa composıçăo foi posteriormente alterada, por influência das recomendações do Conselho Nacional de Saúde (CNS). Entre os equivocos na sua composição estava a inclusão de representantes do poder legislativo no CMS. Além disso, a recomendação do CNS propugnava que o segmento de não-usuários tivesse os gestores, profissionais de saúde e prestadores de serviço representados na mesma proporcionalidade. A criação do Conselho Municipal de Saúde, denominado COMUS em Marilia, e sua designação como órgão deliberativo máximo das questões de saúde no municipio, obedecendo à Lei Orgânica da Saúde, representa, em tese, a distribuição do poder de decisão a outros atores até então fora da cena política local. O CMS passa a fazer parte, formalmente, do sistema de decisões das politicas de saúde.

Com a criação do Fundo Municipal de Saúde (FMS), por intermédio da Lei complementar n. 7 (MARÍLIA ${ }^{\circ 9}, 1991$ ), de 17 de setembro de 1991, as principais disposições legais relacionadas à municipalização da saúde foram instituidas no municipio.

O surgimento do CMS representou concretamente, pelo menos em algum grau, a democratização do processo decisório? Incorporaram-se, de fato, novos atores ao sistema de decisões com o surgimento desse conselho? 
Essas questões estimularam a realização de investigação espe vifica sobre o papel desempenhado pelo Conselho Municipal de Saúde nesse período, para determinar de que forma esse fórum interferiu no processo decisório.

O CMS realizou sua primeira reunião ordinária em 21 de fevereiro de 1991 e fez 27 reuniões, 14 ordinárias e 13 extraordinárias, nos anos de 1991 e 1992. Como verificar se o CMS também passou a exercer alguma influência no sistema municipal de saúde e, se estivesse ocorrendo, como se manifestava? Como já referimos no capítulo 3, para pesquisar essa questão frocurou-se identificar os assuntos que compuseram a agenda do Conselho, quem tornou esses assuntos relevantes na agenda e o destino que lhes foi dado.

Nas 27 reuniões realizadas no periodo de 1991 a 1992 foram tratados de 106 assuntos, como mostra a Tabela 1. Predominaram três grupos: gerenciais e assistenciais (38,7\%), reclamações sobre a qualidade da assistência ou sobre a remuneração dos serviços prestados para o SUS $(28,3 \%)$ e os relacionados à ampliação ou ao aperfeiçoamento do controle social $(23,6 \%)$.

Tabela 1 - Assuntos que entraram na agenda do Conselho Municipal de Saúde nos anos de 1991 e 1992 - Marília-SP.

\begin{tabular}{lll}
\hline Assuntos & $\mathrm{N}^{\circ}$ & $\%$ \\
\hline Regimentais & 6 & 5,7 \\
$\begin{array}{l}\text { Gerenciais e assistenciais } \\
\text { Relacionados a campanhas e programas de saúde nacionais }\end{array}$ & 41 & 38,7 \\
$\begin{array}{l}\text { estaduais } \\
\text { Reclamações sobre qualidade da assistência ou sobre remuneração }\end{array}$ & 30 & 28,3 \\
$\begin{array}{l}\text { dos serviços prestados para o SUS } \\
\text { Relacionados à ampliação ou ao aperfeiçoamento do controle social }\end{array}$ & 25 & 23,6 \\
\hline Total & 106 & 100,0 \\
\hline
\end{tabular}

Fonte: atas do CMS.

Os grupos de assuntos que tiveram maior freqüência na agenda do CMS são analisados a seguir. 


\section{ASSUNTOS GERENCIAIS E ASSISTENCIAIS}

Esses assuntos, em virtude de suas caracteristicas, foram separados em três conjuntos: (1) informes; (2) ligados a mudanças de infra-estrutura física e de recursos humanos - e capacidade instalada da rede de serviços e (3) ligados a mudanças do modelo assistencial - projetos inovadores e estudos de clientela

Os informes representam transmissão de informações entre os membros do CMS Náo se constituiram propriamente em assuntos de agenda politica, apesar de que traziam eventualmente à tona informações que podiam influir nas açōes politicas dos atores

Os assuntos ligados a mudanças de infra-estrutura - física e de recursos humanos - e capacidade instalada da rede de serviços diziam respeito à preocupaçåo com a oferta e a qualidade dos serviços. Traziam, implicitamente, intenções ou propostas concretas de intervenção nessas áreas.

Diferenciavam-se dos ligados à mudanças do modelo assistencial projetos inovadores e estudos de clientela - porque, nesses, as intenções e propostas diziam mais respeito ao modelo assistencial. Colocavam em destaque o processo saúde-doença e os seus determinantes e, em geral, traziam implicitamente uma preocupação que ultrapassava a simples melhoria do modelo de saúde existente, tendo como imagem-objetivo um novo modelo

A Tabela 2 mostra que os informes corresponderam a mais da metade, ou mais precisamente $51,2 \%$, do total de assuntos desse grupo, enquanto os outros dois conjuntos corresponderam a $24,4 \%$ cada um. Isso 
mostra que o CMS desempenhou freqüentemente o papel de ca.ral de transmissão de informações.

Tabela 2 - Distribuição dos assuntos gerenciais e assistenciais discutidos nas reuniões do Conselho Municipal de Saúde nos anos de 1991 e 1992 - Marilia SP.

\begin{tabular}{lccc}
\hline Assuntos & $\mathrm{N}^{\circ}$ & $\%$ \\
\hline $\begin{array}{l}\text { Informes } \\
\text { Ligados a mudanças de infra-estrutura - fisica e de recursos }\end{array}$ & 21 & 51,2 \\
humanos - e capacidade instalada da rede de serviços & & 24,4 \\
$\begin{array}{l}\text { Ligados a mudanças do modelo assistencial - projetos inovadores e } \\
\text { estudos de clientela. }\end{array}$ & 10 & 24,4 \\
\hline Total & 41 & 100,0 \\
\hline
\end{tabular}

A análise do que tornou relevantes os informes citados na Tabela 3 mostra que o governo local e os governos federal e estadual são os que mais se utilizam do CMS, especialmente os primeiros, com 47,8\%, para transmitir informações. O fator classificado como outros foi, no período analisado, todo ele correspondente ao projeto UNI - Uma Nova Iniciativa na Educação dos Profissionais de Saúde: União com a Comunidade, que nessa época estava em fase de planejamento e implantação inicial. Esse projeto, já mencionado no capítulo 3, será analisado com pormenores no próximo período, época em que sua atuação foi mais marcante.

Tabela 3 - Fatores que tornaram relevantes os informes referentes a assuntos gerenciais e assistenciais transmitidos no Conselho Municipal de Saúde, nos anos de 1991 e 1992, em Marília-SP

\begin{tabular}{lll}
\hline Fatores & $\mathrm{N}^{\circ}$ & $\%$ \\
\hline Governos federal e estadual & 4 & 17,4 \\
Governantes locais & 11 & 47,8 \\
Usuários & - & - \\
Prestadores de serviço & 1 & 4,4 \\
Profissionais de saúde & - & - \\
Crise ou eventos dramáticos & 2 & 8,7 \\
Outros & 5 & 21,7 \\
\hline Total & $23^{*}$ & 100,0 \\
\hline
\end{tabular}

* o número total de informes não é necessariamente igual ao número de fatores que os tornaram relevantes porque mais de um fator pode interagir simultaneamente.

Os assuntos ligados a mudanças de infra-estrutura e do modelo assistencial foram trazidos às reuniões do CMS mais freqüentemente pelos 
governantes locais $(61,5 \%$ do total), como mostra a Tabela 4 . Liziam respeito, por exemplo, ao fechamento ou abertura de Unidades Básicas de Saúde, ampliação de recursos humanos na área, tratamento do lixo hospitalar e alterações no fluxo de atendimento dos pacientes do SUS, entre vários outros.

Constituiam, jeralmente, propostas que o Secretário de Saúde e seus assessores traziam para conhecimento dos outros conselheiros. Não existia, propriamente, uma liturgia deliberativa no CMS. Podemos considerar que assuntos como esses eram manifestações esparsas do projeto de intervenção dos governantes locais. Esse projeto sofria as influências do contexto no qual se processavam as mudanças decorrentes da descentralização, que ampliavam as responsabilidades do governo municipal.

Tabela 4 - Fatores que tornaram relevantes os assuntos ligados a mudanças de infraestrutura e do modelo assistencial discutidos no Conselho Municipal de Saúde, nos anos de 1991 e 1992, em Marilia-SP.

\begin{tabular}{lll}
\hline Fatores & $\mathrm{N}^{\circ}$ & $\%$ \\
\hline Governos federal e estadual & 7 & 26,9 \\
Governantes locais & 16 & 61,5 \\
Usuários & - & - \\
Prestadores de serviço & 1 & 3,8 \\
Profissionais de saúde & - & - \\
Crise ou eventos dramáticos & 2 & 7,7 \\
Outros & & -
\end{tabular}

Total* 26 100.0

* o número total de assuntos não é necessariamente igual ao número de fatores que os tornaram relevantes porque mais de um fator pode interagir simultaneamente.

Os governos federal e estadual também foram responsáveis pela inclusão na agenda de algumas propostas gerenciais e assistenciais $(26,9 \%)$, como, por exemplo, obrigatoriedade de interrupção da realização de Pré-Natal em hospitais do SUS, alterações nos índices de valorização de qualidade hospitalar; redefinição dos papeis de unidades de saúde de referência regional etc. Constituíam decisões já tomadas. Cabia aos governantes locais aplicá-las e ao CMS tomar conhecimento das mesmas. 
O destino dado pelo CMS a esses assuntos é mostrado na Tabela 5. Reafirmando o que comentamos no final do capítulo 3, sobre a metodologia utilizada, os assuntos descartados são os desconsiderados pelo fórum decisório. Surgiam nas reuniões, mas eram tratados como mero desabafo ou, então, destituídos de pertinência para os que fazem a agenda. Os que permanecem e, portanto, são considerados pertinentes adquirem status de assuntos de agenda. Os priorizados, além disso, são encaminhados para implementação imediata ou, se isso não fosse possivel, para alguma resposta mais efetiva, ficando bem caracterizada a preocupação com a implementação

Tabela 5 - Destino dado aos assuntos ligados a mudanças de infra-estrutura e do modelo assistencial que entraram na agenda do Conselho Municipal de Saude nos anos de 1991 e 1992 - Marilia-SP.

\begin{tabular}{lll}
\hline Destino & $\mathrm{N}^{\circ}$ & $\%$ \\
\hline Descartado & - & - \\
Permanecem na agenda & 6 & 30,0 \\
Priorizados & 14 & 70,0 \\
\hline Total & 20 & 100,0 \\
\hline
\end{tabular}

Dos 20 assuntos deste grupo nenhum foi descartado pelo CMS. Consolidaram-se como assuntos de agenda. Além de todos adquirirem este status, a maioria - mais precisamente $70 \%$ - foi priorizada.

Considerando que a expressiva maioria foi trazida pelos governantes locais ou por outros niveis de governo, conclui-se pelo elevado peso dos temas de governo no processo de municipalização no periodo. Ou seja, quem formulava politicas locais com potencial de implementação ligadas a mudanças de infra-estrutura e do modelo assistencial eram os governantes locais e os outros niveis de governo. Os atores não-governamentais do CMS não eram propriamente formuladores de politicas no que diz respeito a esses assuntos. Analisavam ou, mais propriamente, tomavam ciência de propostas de intervenção formuladas pelos governantes. 
Os achados mostram também o referendo às ações dos governantes pelos outros atores componentes do CMS (prestadores, usuários e profissionais de saúde), já que esse fórum não recusava - ou descartava as propostas de intervenção apresentadas.

RECLAMAÇÕES SOBRE QUALIDADE DA ASSISTENNCIA OU SOBRE REMUNERAÇÃO DOS SERVIÇOS PRESTADOS

Estas reclamações foram mais freqüentemente ligadas a: (1) baixos valores de remuneração da tabela do SUS; (2) má qualidade do atendimento médico-hospitalar; (3) dificuldade de manter a atual oterta de serviços; (4) solicitação de recursos para investimentos em áreas especificas, entre outras.

A forma pela qual entraram na agenda do CMS è mostrada na Tabela 6. Os prestadores de serviço e os usuários, somados, foram responsáveis por trazer $60 \%$ dos mesmos às reuniōes. É importante ressaltar que esse tipo de assunto diz respeito a formas indiretas de controle social, pois representam a pressão de representantes da sociedade civil sobre os governantes locais, visando o atendimento de suas reivindicações. Além disso, como era de se esperar, as reclamações sobre qualidade da assistência são predominantemente feitas por usuários e sobre remuneração dos serviços pelos prestadores.

A Faculdade de Medicina (FAMEMA) e algumas Organizações nãoGovernamentais (ONGs), inseridos em outros fatores na Tabela 6, foram responsáveis, em 22,9\%, pela freqüência de aparecimento desse tipo de assunto, mostrando que o CMS foi utilizado como canal de pressão também pur não- conselheiros de saúde. 
Tabela 6 - Fatores que tornaram relevantes os assuntos relacionados às reclamaçôes sobre qualidade da assistência ou sobre remuneração dos serviços discutidas no Conselho Municipal de Saúde, nos anos de 1991 e 1992, em Marilia-SP.

\begin{tabular}{lll}
\hline Fatores & $\mathrm{N}^{\circ}$ & $\%$ \\
\hline Governos federal e estadual & - & - \\
Governantes locais & 3 & 8,6 \\
Usuários & 10 & 28,6 \\
Prestadores de serviço & 11 & 31.4 \\
Profissionais de saude & 2 & 5.7 \\
Crise ou eventos dramáticos & 1 & 2.9 \\
Outros & 8 & 22.9 \\
\hline Total & $35^{*}$ & 100.0 \\
\hline
\end{tabular}

* o número total de assuntos não é necessariamente igual ao número de fatorer que os tornaram relevantes porque mais de um fator pode interagir simultaneaments

Como mostra a Tabela 7, 46,7\% desses assuntos foram descartados. Entre eles encontravam-se desde alguns que extrapolavam a capacidade de intervenção local, tais como reclamações sobre alguns valores de remuneração muito defasados da tabela do SUS, até outros que contrariavam a concepção de modelo assistencial dos governantes locais, como, por exemplo, pedido de aquisição de ambulância feito por vereador para atender determinada área do município.

Tabela 7 - Destino dado às reclamações sobre qualidade da assistência ou sobre remuneração dos serviços que entraram na agenda do Conselho Municipal de Saúde nos anos de 1991 e 1992 - Marília-SP.

\begin{tabular}{lll}
\hline Destino & $\mathrm{N}^{\circ}$ & $\%$ \\
\hline Descartado & 14 & 46.7 \\
Permanecem na agenda & 12 & 40,0 \\
Priorizados & 4 & 13,3 \\
\hline Total & 30 & 100.0 \\
\hline
\end{tabular}

Outros $(40 \%)$ entraram na agenda mas não foram encaminhados para implementação. Foram considerados pertinentes, porém não estavam presentes as condições necessárias para sua implementação. Ficaram "latentes". Não desencadearam ações concretas de intervenção. São exemplos dessa situação: solicitação de recursos para investimentos em 
hospitais filantrópicos, oferta insuficiente de serviços auxiliares de diagnose e terapia (SADT), baixa resolubilidade das unidades básicas de saúde etc.

Alguns (13,3\%), por sua vez, não só entraram na agenda do CMS como desencadearam ações de intervenção concreta para o seu atendimento. Exemplos: cessão de determinado profissional de saúde para atender situação emergencial em algum serviço do SUS, reforma em UBS por pressão organizada da população local, transmitida por um conselheirousuário, instauração de algum procedimento administrativo em decorrência de queixa sobre cobrança indevida ou mal atendimento etc.

Percebe-se, em sintese, que os atores não-governamentais tiveram espaço de reclamação e reivindicação no CMS. A resposta dos governantes, no entanto, foi pouco expressiva. A maior parte dos assuntos não teve encaminhamento adequado e a principal causa disso foi a limitação do poder local. Conseguiam dar resposta a algumas reivindicaçōes e reclamaçōes que se enquadravam dentro do seu espaço de poder. Esse espaço, no entanto, era bastante restrito.

\section{ASSUNTOS RELACIONADOS À AMPLIAÇĀO OU APERFEIÇOAMENTO DO CONTROLE SOCIAL}

Os fatores que tornaram esses assuntos relevantes são mostrados na Tabela 8, predominando entre eles os governos federal e estadual $(70,6 \%)$, seguidos pelos governantes locais $(26,5 \%)$. Diziam respeito esses assuntos à: criação do Fundo Municipal de Saúde e à fiscalização de suas contas, à prestação de contas de convênios, à realização de conferências etc. 
Tabela 8 - Fatores que tornaram relevantes os assuntos relacionados à ampliação ou aperfeiçoamento do controle social discutidas no Conselho Municipal de Saúde, nos anos de 1991 e 1992, em Marilia-SP.

\begin{tabular}{lll}
\hline Fatores & $\mathrm{N}^{\circ}$ & $\%$ \\
\hline Governos federal e estadual & 24 & 70,6 \\
Governantes locais & 9 & 26,5 \\
Usuários & 1 & 2,9 \\
Prestadores de serviço & - & - \\
Profissionais de saúde & - & - \\
Crise ou eventos dramáticos & - & - \\
Outros & - & - \\
\hline Total & $34^{*}$ & 100,0
\end{tabular}

* o número total de assuntos não é necessariamente igual ao número de fatores que os tornaram relevantes porque mais de um fator pode interagir simultaneamente

A Tabela 9 mostra o destino desses assuntos; foram eles priorizados e desencadearam, em grande maioria ( $88 \%$ do total), ações efetivas de implementação, tais como, por exemplo: apreciação e aprovação de contas dos recursos do fundo, aprovação de realização de Conferência Municipal de Saúde, indicação de delegados para conferências estadual ou nacional etc. A instıtucionalização da participação da população no SUS, por intermédio de conferências e conselhos de saúde, conforme preconiza a Lei Orgânica da Saúde, estava ocorrendo.

Tabela 9 - Destino dado aos assuntos relacionados à ampliação ou aperfeiçoamento do controle social que entraram na agenda do Conselho Municipal de Saúde nos anos de 1991 e 1992 - Marilia-SP

\begin{tabular}{lll}
\hline Destino & $\mathrm{N}^{\circ}$ & $\%$ \\
\hline Descartado & 1 & 4,0 \\
Permanecem na agenda & 2 & 8,0 \\
Priorizados & 22 & 88,0 \\
\hline Total & 25 & 100.0 \\
\hline
\end{tabular}

Como se pode verificar, as propostas de ampliação e aperfeiçoamento do controle social foram formuladas em sua maioria pelos governos federal e estadual e estavam sendo institucionalizadas pelo poder local através do CMS. Os requisitos legais impostos ao município o obrigavam a institucionalizar os mecanismos de fiscalização de recursos, realização de conferências, elaboração de planos de saúde etc. Se o 
municipio não fizesse isso contrariaria as normas legais e não receberia os recursos federais. Isto é, o repasse de recursos ao municipio e a aprovação de contas e convênios estavam condicionados à institucionalização das medidas de controle exigidas pelos governos federal e estadual.

\section{SINTESE DO PAPEL DO CMS NO PERIOODO}

Em sintese, o CMS, nos anos de 1991 e 1992, caracterizou-se por:

(1) Ser freqüentemente utilizado como local propicio para que os governantes locais e algumas organizaçōes de saúde transmitissem informações aos participantes das reuniōes.

(2) Constituir-se em arena politica na qual os governantes locais e, menos freqüentemente outros niveis de governo, propusessem mudanças a serem efetivadas nos modelos gerencial e assistencial do municipio. Essas propostas de mudança, apesar de limitadas pela pouca governança local desse período, foram referendadas, ou seja, aprovadas, pelos outros atores locais presentes.

(3) Constituir-se em caixa de ressonância de queixas e reclamações de prestadores de serviço e usuários. Essas queixas não foram solucionadas, em sua maioria, pois o CMS e os governantes locais não tinham poder suficiente para isso.

(4) Contribuir para a institucionalização de novas formas de controle na aplicação dos recursos do SUS, fiscalizando convênios e contas do Fundo Municipal de Saúde, tendo como ideário transparência, controle púbico e accountability.

A avaliação do papel exercido pelo CMS de Marilia, nesse periodo, coincide em parte com a constatação de CHIRELLI $^{30}(1995$, p.96) segundo a 
qual a participação popular, tanto na CIMS, do periodo anterior, quant’ no CMS, nesse período, limitavam-se a denúncias. Essa autora atribui as causas desse fato ao dominio que o saber técnico do governantes e de outros atores, que detinham o conhecimento cientifico, exercia sobre os representantes populares. Propunha, como proposta de reversão dessa situação e da construção de uma gestão mais democrática, a democratização da informação. Dessa forma, segundo a autora, o "denuncismo" poderia ser substituido por uma intervenção mais efetiva dos representantes populares no processo decisório.

Consideramos, à semelhança da autora, que a democratização das informaçōes, disponibilizando-as aos usuários e seus representantes, constitui fator de primordial importância para que esses atores aperfeiçoem suas estratégias de participação no jogo politico, como um todo, e no CMS de forma particular. Admitimos, no entanto, que outros fatores também influenciaram sobre as limitações do Conselho Municipal de Saúde para tratar de assuntos de interesse dos usuários, os quais dizem respeito a aspectos conjunturais, decorrentes da pouca autonomia de gestão do periodo, e estruturais, ligados aos limites do poder local. Esse tema será explorado e analisado ao longo deste estudo, tanto neste quanto no próximo capitulo.

Para finalizar, procurando responder as questōes anteriormente formuladas sobre o papel do CMS, consideramos que a incorporação de novos atores ao sistema de decisões das políticas locais de saúde, visando democratizar o processo decisório, foi realizada. Foram criados o Conselho Municipal de Saúde e o Fundo Municipal de Saúde, medidas que, no entanto, tiveram pouco resultado. Os atores que participaram desses canais e que deveriam incorporar-se mais efetivamente ao processo decisório, foram protagonistas secundários e pouco relevantes. Restava a esperança de que essa correspondesse a apenas uma etapa preliminar e que seriam criadas condições mais favoráveis no futuro. 


\subsection{Período de 1993 a 1996}

O PDS assume a administração municipal em 1993, substituindo o PMDB, que estava no poder há dez anos. É, então, publicada a NOB SUS/93, o que representou, como citamos no capítulo 1 , possibilidade concreta de ampliação da autonomia da gestão municipalizada, especialmente pela criação da forma de gestão "semiplena".

Essa norma demorou algum tempo para entrar em vigor em decorrência do impasse referente ao montante de recursos que seriam transferidos, na forma semiplena, do Fundo Nacional de Saúde para os fundos municipais. Os valores inicialmente propostos pelo Ministério da Saúde eram inferiores às expectativas do movimento municipalista e, em especial, de muitos prefeitos e secretários que se dispunham a assumir a gestão semiplena, mas estavam com algum receio de fazê-lo.

Esses administradores estavam receosos em assumir uma forma diferente de gestão, inovadora porém arriscada, sem a contrapartida financeira que thes assegurasse que no, final do mês, não faltariam recursos para pagar a rede contratada de serviços de saúde do município.

Alguns prefeitos consideravam, com razoável dose de razão, que os propósitos descentralizantes dos governos federal e estadual, nas áreas de educação, assistência social e saúde, por exemplo, tinham como principal intenção transferir encargos e responsabilidades para os governantes municipais. Com essa percepção do processo de descentralização, é compreensivel que esses governantes assumissem apenas o que thes fosse imprescindivel, atuando no limite de suas obrigações legais, e resistissem a assumir mais encargos. 
A implantação da NOB SUS 01/93, nesse contexto, encontrava dificuldades para a sua implantação. Procurando estimular a adesão à gestão semiplena, o Ministério da Saúde criou incentivos financeiros aos primeiros municipios que se dispusessem a se habilitar. Os mais "ousados" receberiam uma transferência de recursos superior à média histórica de gastos com a prestação de serviços do SUS. Esses municípios teriam, portanto, uma margem de segurança que thes estimulassem a assumir o "risco" de municipalizar mais radicalmente a saúde.

Esses incentivos adicionais levaram algumas dezenas de municipios, quase todos de médio e grande porte, a assumirem a gestāo semplena no ano de 1994. Outros se juntaram a esses nos anos seguintes como já mencionamos no capítulo 1. Muitos municipios, porém, não assumiram a gestão semiplena, mesmo tendo requisitos suficientes para isso, esse foi o caso de Marilia.

Ao optar pela forma de gestão parcial em 05/10/94, e não pela semiplena, a Secretaria Municipal de Saúde de Marilia manteve-se com o repasse dos recursos federais equivalentes aos serviços prestados por sua rede municipal de saúde. Não incorporou, à sua condição de gestão, a prerrogativa de, por exemplo, modificar a relação contratual com a rede de serviços contratados na áreas ambulatorial especializada e hospitalar. Medidas como essa mantinham a gestão centralizada nos governos estadual e federal. Isso desagradou os aliados do movimento sanitário, como veremos a seguir.

\subsubsection{Divergências, discordâncias e alianças entre os atores locais}

A não-adesão de Marilia à gestão semiplena foi considerada pelos aliados do movimento sanitário como um equívoco dos governantes locais. Essa percepção está presente em diversas entrevistas, como mostramos nos depoimentos transcritos a seguir: 
(..) a gente teve, em outros períodos, dificuldade de avançar. Isto se deveu a um certo receio de alguns secretários e, muitas vezes, dos próprios prefeitos, que temiam ... a questão dos recursos. Pensavam assim: serviços (muitos) (...) mas dinheiro que é bom, nada. O governo municipal tinha receio de assumir. Agora, mais recentemente esse processo pôde avançar. Acho que está avançando. Foi assinada a Plena do Sistema (Gestor 7).

(com relação) à NOB 93. Em Marilia eu tenho a impressão de que ela não teve muito impacto, até porque o município acabou não se habilitando na semiplena. Ficou na parcial c praticamente, segundo o meu ponto de vista, não houve nenhum impacto (em Marília) (Gestor 5).

Alguns falavam em "falta de avanço" e outros em "retrocesso" como características desse periodo Os aliados do movimento sanitário consideravam que a Secretaria Municipal de Saúde tinha pouca autonomia e pouca capacidade de ação, tanto em decorrência da não-adesão à gestão semiplena, quanto devido ao reduzido investimento de recursos municipais para a saúde nesse período, que se mantinham em valores próximos de 4 a $5 \%$ do orçamento municipal. Consıderavam que os governantes locais não tinham interesse, ou seja, "vontade política", para assumir as novas responsabilidades previstas na gestão semiplena.

As dificuldades financeiras enfrentadas pela Secretaria da Saúde só poderiam ser resolvidas, de acordo com os críticos da não-adesão à semiplena, com ampliação da governabilidade na utilização dos recursos do SUS e com um projeto consistente de mudança nas práticas sanitárias. No discurso, os governantes da saúde até concordavam com isso; mas não agiam nesse sentido. Os registros abaixo ressaltam esse aspecto:

O (referindo-se ao secretário de então) era médico, era super gente boa. Só que ele falava muito (sobre a municipalização na forma de gestão semiplena) que era legal, era legal, só que ela (a Secretaria) não tomava nenhuma atitude pra coisa acontecer. Uma coisa que dá trabalho, maiores responsabilidades, ninguém quer assumir mesmo (Usuário 1). 
Nós tínhamos a grande esperança, quando surgiu a campanha política com (referindo-se ao prefeito da época) um promotor público ... filantropo, da comunidade espírita (...) Então a gente confiava muito. Nós tivemos decepção. Foi um prefeito que não falava não por nada. Tudo aquilo que a gente dizia, ele dizia sim. Mas, na ação, não funcionava. A gente tinha até admiração por ele. Aqui em casa, muitas vezes nós sentamos juntos e a gente reunia o povo, sentava aqui, nós conversávamos, ele dizia, vai ser feito e ... não acontecia. Então (referindo-se ao Secretário da época), é um médico que eu conheço há 35 anos. Ele já era médico, e nós nos conhecíamos. Tenho grande admiração. Mas não pôde fazer muita coisa, pois não tinha apoio (Usuário 2).

A rede voltou para trás. Todos os programas. (...) Ficou trabalhando só com pronto atendimento. Acabou com as atividades programáticas. Foi literalmente um retrocesso. E o que é pior: não assumiu a gestão. De jeito nenhum. Não assumiu discutir com prestador. Quando você via Campinas, São José dos Campos, ... a todo vapor. A gente estava andando a passos de tartaruga (Gestor 6 ).

$\mathrm{Na}$ análise da racionalidade de alguns governantes locais do setor saúde, subordinados ao prefeito, percebemos que reconheciam igualmente a falta de governabilidade e a falta de apoio do Prefeito. As dificuldades que enfrentavam eram atribuidas, no entanto, também a outros fatores, entre os quais a boicotes de grupos politicos rivais e a dificuldades estruturais mais amplas:

Aqui em Marilia eu participei da administração anterior. O Secretário não assinava cheques. E nem autorizava despesas. $\dot{E}$ lógico que ele acompanhava (o que acontecia) mas, a parte financeira ... (não tinha autonomia para decidir) (Gestor 4 ).

(como o Prefeito dificultava?) De duas maneiras. Ou frenando um pouquinho toda a evolução do processo ou abrindo de uma maneira que não é muito acompanhada pelos recursos, não é. Nossa administração, por exemplo, tinha um bom diálogo com o prefeito. Mas, por outro lado, (ele) não deu condições da gente avançar mais. Por falta de recursos. Não adianta dizer que é uma beleza e tal, mas precisa de recursos. Precisa contratar pessoal (Gestor 4).

A gente nunca atuou em política partidária ... atuou na política do órgão, mas não na partidária. Mas era muito comum a gente encontrar o pessoal que estava mais envolvido com a política e falar assim: olha, se nós não encontrarmos nada que vocês estejam fazendo de errado, nós vamos 
inventar. Mas nós temos que arrasar com isso aí. E realmente são cartas coisas, que você trabalha dentro de uma certa pureza que ela não existe. Você pensa que está compromissado com o bem comum e tem coisas por trás aí que ... (Gestor 4$)$.

(um dos principais fatores de dificuldade é a) própria estrutura. Pensar que já existe uma clara definição dos papeís dos níveis federal, estadual e municipal, não é bem assim. Há trombadas aí que você não pode avançar porque esbarra muitas vezes com uma legislação estadual que .. gente do próprio poder estatal, do Estado, não é. Não adianta só pensar em Marilia, Londrina etc., que têm uma certa estrutura, mas você tem aí municípios que precisam ser equacionados. Algumas coisas a gente quer avançar, mas aí vem o Estado e: Não! Isto é competência nossa. Isto é um fator impeditivo. Você tem que fazer como com a Educação, ter uma verba orçamentária e contar com aquilo. E, mesmo sendo pouco, dá pra avançar bastante. Você estabelece as prioridades e avança no processo. (Gestor 4).

Segundo a percepção dos governantes locais do setor saúde, como se vê pelas opiniões destacadas, a realidade é interpretada de uma forma diferente daquela feita pelos aliados do movimento sanitário. Sentem as dificuldades. Sentem que as "coisas não estão indo bem". Nesse particular concordam com os aliados do movimento sanitário. Explicam as dificuldades, porém, de forma diferente. Para eles, além da falta de apoio do prefeito, obstáculos políticos conjunturais e dificuldades estruturais, que ultrapassam os limites do poder que possuem, explicam os problemas existentes no sistema de saúde.

Os aliados do movimento sanitário reconheciam a existência dessas dificuldades. Entendiam, no entanto, como já comentamos, que a adesão à gestão semiplena daria mais autonomia aos administradores municipais para que pudessem superar as dificuldades e viabilizar o projeto da reforma sanitária.

A Secretaria Estadual de Saúde, por intermédio de seu órgão regional, continuava forte no cenário da saúde local. O Escritório Regional de Saúde (ERSA 45) de Marilia foi extinto e foram criadas as Diretorias Regionais (DIR XIV). Essas novas estruturas acrescentaram mais 22 
municípios da região aos 13 que estavam na área do ERSA 45. A Faculcade de Medicina de Marilia (FAMEMA), mantida pela Fundação Municipal de Ensino Superior (FUMES), foi estadualizada no final desse periodo, ficando vinculada à Secretaria de Ciência e Tecnologia do Estado de São Paulo. A FAMEMA, em todo esse período, mesmo quando sob o comando do município, foi dirigida por aliados do movimento sanitário.

Em situação de reduzida autonomia na gestão da saúde e de restrição de recursos, que se acentuaram ainda mais nesse período, o municipio de Marilia passou a sofrer invasão de pacientes dos municipios vizinhos, maior do que a média histórica habitual, ampliando as dificuldades de acesso aos serviços de atenção secundária e terciária (Projeto UNI Marilia ${ }^{97}$, 1996).

Esses fatos contribuíram para ampliar os problemas da gestão municipal, que sofria os impactos de uma demanda reprimida nos diversos niveis da assistência e, conseqüentemente, de insatisfação dos usuários. A elevação da demanda deve ter contribuido também para pressionar por uma elevação do aporte de recursos municipais, como aliás ocorreu na maioria dos municípios de médio e grande porte do Brasil, nessa época.

Esse aporte, no ano de 1996, foi de $10 \%$ do orçamento geral do municipio, equivalendo, em valores da época a $R \$ 3.489 .995,59$ (três milhões, quatrocentos e oitenta e nove mil, novecentos e noventa e cinco reais e cinqüenta e nove centavos) (MARILIA $\left.{ }^{72}, 1997\right)$. Mesmo ampliando os gastos com o setor, em virtude da magnitude dos problemas e da pouca capacidade de intervenção dos gestores municipais no modelo assistencial vigente, mantiveram-se as dificuldades.

Nesse contexto é firmada uma parceria entre os serviços municipais de saúde e a Faculdade de Medicina, através da adesão ao projeto UNI (Uma Nova Iniciativa na Educação dos Profissionais de Saúde). Participam 
também representantes da Comunidade e da Diretoria Regional da Secretaria Estadual de Saúde. Esse projeto, apesar de ter início em setembro de 1992, com a aprovação das "cartas de intenção" dos Projetos UNI na América Latina, começa efetivamente a ser implementado a partir de 1993

\subsubsection{O Projeto UNI/Marilia}

Marilia fez parte do primeiro grupo de municipios onde foi implantado esse projeto, que è apoiado pelo Fundação Kellog e tem como porta de entrada a Universidade ou a Facuidade local. Alem do acadêmico, dois outros componentes fazem parte do projeto: os Serviços de Saúde e a Comunidade. Os resultados esperados para cada um dos componentes eram, em sintese, os seguintes (KISIL e CHAVES ${ }^{59}$ 1994, p.16):

(1) $\mathrm{Na}$ Comunidade: desenvolvimento de autocuidados em saúde; participação efetiva na gestāo oos SILOS (Sistemas Locais de Saúde); envolvimento em atividades multiprofissionais com a Universidade e os Serviços, e desenvolvimento de lıderanças comunitárias para atuação em saúde.

(2) Na Universidade: modelos académicos de união com a Comunidade e em articulação com os Serviços de Saúde, envolvendo: tecnologias apropriadas para ensino-aprendizagem, ajustes curriculares e atividades de investigação orientadas por problemas dos outros componentes.

(3) Nos Serviços: modelos de SILOS, envolvendo enfoque familiar, espaço e equipamento necessários para ensino-aprendizagem das várias profissões de saúde participantes.

Os projetos UNI têm sido estudados em diferentes dimensões e perspectivas. Para os propósitos do estudo de caso nos interessa abordar mais especificamente as influências que o projeto teve no processo de municipalização em Marilia.

Os entrevistados manifestaram-se de forma unanimemente favorável ao projeto-UNI Marília e ressaltaram sua contribuição ao processo de 
municipalização da saúde. A par dessa unanimidade, consideramos necessário analisar, no entanto, quais foram os aspectos do projeto que significaram, de acordo com a racionalidade desses atores, benefícios para a municipalização da saúde. Uma dessas avaliações é ressaltada no depoimento que se segue:

Ocorreu em Marilia nesse periodo um outro fato, que na minha opiniāo foi importantc para o processo de municipalização, que foi o projeto UNI. ()s contatos começaram antes, mas foi em 92, 93 que ele começou a deslanchar. E o projeto UNI, na verdade, como eu sempre coloco ... é o sI'S. É a integração da academia com os serviços. Que está nas diretrizes dn SUS. Apoio à formação de Recursos Humanos. Participação da ( omunidade. O projeto UNI dá mais ênfase à participação. 'Tem um componente, Comunidade, que também é uma das diretrizes fortes do ¿IS. Então, basicamente o projeto UNI ocupou aquele espaço que deixou de ser ocupado pelo próprio sistema. Eu acho que aqui em Marilia, de 1993 a 1996, o SUS ficou meio paralisado. Os municipios que entraram em semiplena avançaram, os outros não avançaram. Em Marília ru acho que o projeto UNI alavancou esse processo. Houve muito crescimento da rede básica, graças ao projeto UNI. Aumentou a integração. Eu acho que um dos componentes que mais se desenvolveu nesse período foi a comunidade. Era o componente assim ... mais atrasado, vamos dizer. Então deu-se muita ênfase à formaçào de Conselhos locais. Houve muito curso para conselheiros. Muita tentativa de formação de sociedade de amigos de bairros. Um dos projetos do componente comunidade foi regularizar a situação de sociedade amigos de bairros. $O$ pessoal do componente comunidade foi visitar outras áreas ... Londrina ... vieram muitas pessoas de fora ... houve muitos encontros. Então eu acho que foi um componente muito importante. Eu acho então que o projeto UNI circulou ... quer dizer, ele manteve o processo de municipalização e integração. Só que o projeto UNI não avançou no nível sccundário e terciário. Ele ficou mais em termos de municipio. Mas em termos de rede básica. $O$ projeto UNI investiu na rede básica, na área física ... informatizou toda rede básica. Se o município tivesse entrado na semiplena ele teria (investido) muito mais. Nós iríamos ter um investimento muito grande, do ponto de vista do SUS. Na semiplena, os municípios que entraram, numa fase inicial tiveram um aporte maior de recursos até do que a série histórica. Infelizmente junto com o projeto UNI não tivemos essa composição (de entrar na semiplena) (Gestor 5).

De acordo com essa percepção, o Projeto UNI-Marilia veio preencher o vácuo decorrente da não-entrada do municipio em gestão semiplena. $O$ ideário do projeto, segundo o registro acima, e que é partilhado por outros entrevistados, coincidia integralmente com o do SUS. Os aliados do 
movimento sanitário defendiam e apoiavam o projeto. Esse representaria avanços para o sistema municipal de saúde, capacitando recursos humanos, ampliando e reestruturando organizacionalmente a rede básica de saúde e promovendo a participação da comunidade. Lamentam o fato de que não tivesse ocorrido, juntamente com o projeto UNI, a adesão à gestão semiplena, pois isso possibilitaria intervir também nas áreas especializada e hospitalar.

Outros identificaram outros aspectos no projeto, para justificar sua aprovação

Depois veio o projeto UNI, que ajudou muito. É um projeto internacional, financiado por uma entidade internacional que também entrou nessa parceria (Gestor 1).

Eu acho que o projeto UNI (contribui bastante). Por ser um projeto de parceria, por estar se discutindo mais os projetos ligados à saúde, isto acabou capacitando a população e também os profissionais. Falta de informação não é só da população. Das pessoas que trabalham também nas Unidades de Saúde, nos Hospitais (também). Isso acabou influenciando. $E$ a gente começou a entender porque a Unidade Básica tem que fazer o atendimento primário. E porque tem que deixar $o$ atendimento de alta complexidade para um Hospital terciário. Apesar de que a gente também acha que a pessoa, onde ela chega, ela deveria ser atendida. Mas, tudo bem. Nós tivemos esse entendimento, e o que possibilitou esse entendimento foi o projeto UNI. Toda essa capacitação, divulgando informação ... (Usuário 1).

Sempre trabalhava na comunidade. Muitos anos. E aí depois, com a vinda do UNI a gente fez a capacitação .. o projeto deu essa iniciativa pra nós. $O$ projeto veio, como se diz, para ficar. Pode ser que amanhã nós não tenhamos mais a colaboração deles, financeira. Mas a colaboração de ética a gente vai levar, porque isso veio pra ficar (Usuário 2).

Eu acho que ele (o projeto UNI) veio trazer uma discussão mais séria do projeto de municipalização. Pelos seus objetivos, ele desospitalizou a questão do ensino. Pelo menos como meta. É preciso avaliar melhor ... estamos aí no quarto ano (novo currículo). Então eu acho que ele fortaleceu o processo (Profissional de saúde 1). 
... a prática de democratização em nosso país não é habitual ... e a municipalização vem sendo um estímulo nesse sentido. Sendo as decisões centralizadas não há o hábito de participação, tanto dos usuários quanto dos prestadores ... dos serviços complementares ... eu acho que nós ainda precisaríamos incentivar mais essa participação ... num nível mais pleno. Nós ainda precisamos dar esse passo. Em Marília foram dados passos nesse sentido ... porque, através do projeto UNI, queira-se ou não, ele investiu, capacitou pessoas e tiveram condição, na rede, os usuários, de fazer cursos. Os vários cursos, aos usuários, aos profissionais incentivou a participação. Eu acho que ainda (persiste) uma questão concreta: nós sabemos que há um limite em termos de recursos (Parlamentar 1).

Apesar da adesão praticamente unânime ao projeto UNI-Marilia, foi possivel perceber divergências a respeito de como deveria ser a condução do projeto

O projeto Uni contribuiu bastante. Ajudou. $O$ convênio deveria ser feito com o municipio. Esse convênio deveria ser feito com os serviços. Porque o convênio é para reunir Serviços, Universidade e Comunidade. E, sem dúvida, os serviços são o ponto de encontro dos dois. Nesse ponto eu achei que avançou bastante mas poderia ter avançado mais. Um (dos obstáculos à municipalização) foi esse: o processo estar colocado dentro da Universidade. Mas de qualquer forma ele possibilitou a expansão da rede básica. Possibilitou a ida do corpo docente e discente para as UBS. Possibilitou um início de organização da comunidade diante das propostas. Sem dúvida alguma foi um avanço ... (Gestor 4).

Uma questão importante do projeto UNI foi a questão da condução. Começou no final da gestão anterior (89-92), que tinha uma determinada diretriz política. Com a mudança ... aí vem um viés de oposição ... e eu acho que ficou aquela posição de que a Universidade estava querendo usar os serviços. Isto gerou uma certa resistência da rede (à integração) (Gestor 7).

Foi possivel perceber também problemas na integração entre os

Serviços de Saúde e a Universidade:

Houve por parte dos profissionais da rede uma certa resistência. (...) Uma certa "ciumeira". A resistência era que a gente determinava muito as coisas. Tinha alguns problemas de gerência. Criava alguns conflitos. Tinha que ir lá resolver. A ida de alunos. A implementação de programas. A mudança do modelo assistencial era complicada também. Na implementação, era complicado também. No operacional. Porque uma coisa era decidido no nível gerencial, mas era mais difícil a operacionalização. Mas deu pra trabalhar. Eu acho que houve avanços. Deu pra trabalhar (Prestador 4). 
O projeto UNI ocorreu nesse periodo em que os governantes locais tinham pouca autonomia na gestão do sistema de saúde, como comentamos anteriormente. A Secretaria de Saúde não ampliou substancialmente sua autonomia com a execução do projeto, pois, mesmo sendo um projeto de parceria, era a Universidade que detinha mais poder na sua condução do que os outros segmentos, já que cabia a ela a sua coordenação.

O fato de os governantes locais terem dificuldade para implementar mudanças no sistema de saúde, sob sua coordenação direta, deu oportunidade a que o projeto UNI, nesse contexto, passasse a influir de maneira marcante na agenda da municipalização da saúde. Os governantes municipais continuaram "atores secundários" no processo de municipalização.

Os aliados do movimento sanitário entendiam que o projeto UNI supriu a falta da viabilização de um projeto mais consistente do governo local na época, como se verifica na afirmativa seguinte:

(o governo da época) teve tanta sorte que o projeto UNI resolveu o problema dele (Gestor 6).

O projeto UNI contribuiu para a formulação e para a implementação de politicas para os serviços de saúde. Propiciou a execução de ações de planejamento da gestão do sistema de saúde municipal, capacitação de recursos humanos, investimentos em determinadas áreas relacionadas à infra-estrutura física e de equipamentos da rede de serviços. Estimulou mudanças, ao colocar na agenda política dos governantes locais da saúde assuntos ligados ao ideário UNI. Entre esses se sobressairam: a constituição de um novo modelo assistencial, baseado na estratégia de criação e consolidação dos SILOS - Sistemas Locais de Saúde, a participação da comunidade nas questões de saúde, inclusive na gestão dos SILOS e a integração com a Universidade, especialmente com a finalidade 
de contribuir para o aperfeiçoamento e a adequação do ensino na área das profissões de saúde.

Não é objetivo deste estudo analisar os resultados do projeto como um todo, mas sim o de sua influência no contexto da municipalização da saúde e no sistema de decisões das políticas locais. Com respeito a esse segundo ponto, além de propiciar maior visibilidade e integração dos parceiros nas mudanças da saúde local, o projeto UNI estimulou e apoiou a constituição de diversos Conselhos Locais de Saúde (CLS), que serão analisados adiante. Os CLS vieram somar-se aos outros atores relevantes: governantes locais alıados do movimento sanitário e Conselho Municipal de Saúde. O comportamento deste último, nesse período, será analisado a seguir.

\subsubsection{O Conselho Municipal de Saúde}

De 1993 a 1996, o CMS realizou 31 reuniões (18 ordinárias e 13 extraordinárias). A Tabela 10 mostra a distribuição dos 108 assuntos dessas reuniões. Observou-se predomínio de assuntos gerenciais e assistenciais, com $36,1 \%$, seguido dos relacionados à ampliação ou ao aperfeiçoamento do controle social $(32,4 \%)$, reclamações sobre a qualidade da assistência ou sobre a remuneração dos serviços prestados pelo SUS e de campanhas e programas de saúde nacionais e estaduais, cada um dos quais com $12 \%$.

Tabela 10 - Assuntos que entraram na agenda do Conselho Municipal de Saúde no período de1993 a 1996 - Marilia-SP.

\begin{tabular}{|c|c|c|}
\hline Assuntos & $N^{\circ}$ & $\%$ \\
\hline Regimentais & 8 & 7,4 \\
\hline Propostas gerenciais e assistenciais & 39 & 36,1 \\
\hline $\begin{array}{l}\text { Relacionados a campanhas e programas de saúde nacionais e } \\
\text { estaduais }\end{array}$ & 13 & 12 \\
\hline $\begin{array}{l}\text { Reclamações sobre qualidade da assistência ou sobre remuneração } \\
\text { dos serviços prestados para o SUS }\end{array}$ & 13 & 12 \\
\hline Relacionados à ampliação ou ao aperfeiçoamento do controle social & 35 & 32,4 \\
\hline Total & 108 & 100.0 \\
\hline
\end{tabular}

Fonte: atas do CMS. 
Comparando essa distribuição com a que se verificou no período anterior, de 1989 a 1992 (apresentada na Figura 4), alguns fatos chamam a atenção: (1) as propostas gerenciais e assistenciais continuaram predominantes; (2) houve expressiva redução na freqüência de reclamações e reivindicações; (3) ocorreu aumento na freqüência de assuntos relacionados a campanhas e programas de saúde nacionais e estaduais e dos assuntos relacionados ao aperfeiçoamento do controle social.

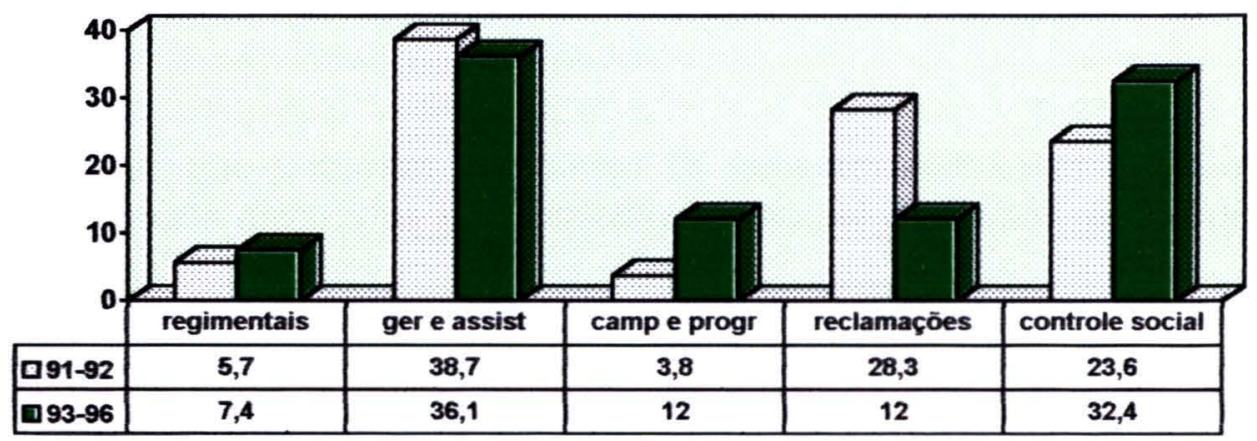

Figura 4 - Comparação entre as freqüências dos assuntos que surgiram nas reuniões do Conselho Municipal de Saúde, nos períodos de 1991 a 1992 e 1993 a 1996 - Marília-SP (em \%)

\section{ASSUNTOS GERENCIAIS E ASSISTENCIAIS}

Assuntos gerenciais e assistenciais surgiram nas reuniões do CMS em diferentes contextos. Referiam-se a, por exemplo, municipalização de unidades estadualizadas, estudos de demanda reprimida em assistência médico-hospitalar, analise crítica de eficiência/eficácia de ações de saúde; programação da assistência e integração ensino-serviço-comunidade, entre outros. 
Como mostram as Tabelas 11 e 12, surgiram como informes em pouco mais da metade dos assuntos do grupo, tendo-se tornado relevantes por influência direta ou indireta dos governos federal/estadual $(36,8 \%)$, governantes locais $(31,6 \%)$ e por outros proponentes - projeto UNI, Universidade de Marilia (UNIMAR) e Sindicato dos Médicos - $(31,6 \%)$.

Tabela 11 - Distribuição dos assuntos gerenciais e assistenciais que surgiram nas reuniões do Conselho Municipal de Saúde, no período de 1993 a 1996 - Marilia-SP.

\begin{tabular}{llc}
\hline Assuntos & $N^{\mathbf{0}}$ & $\%$ \\
\hline Informes & 18 & 51,4 \\
Ligados a mudanças de infra-estrutura - fisica e de recursos & 5 & 14,3 \\
humanos - capacidade instalada da rede de serviços & & \\
$\begin{array}{l}\text { Ligados a mudanças do modelo assistencial - projetos inovadores e } \\
\text { estudos de clientela. }\end{array}$ & 35 & \multirow{2}{*}{\begin{tabular}{c}
12,3 \\
\hline Total
\end{tabular}} \\
\hline
\end{tabular}

Tabela 12 - Fatores que tornaram relevantes os informes referentes a assuntos gerenciais e assistenciais discutidos no Conselho Municipal de Saúde, nos anos de 1993 a 1996, em Marilia-SP.

\begin{tabular}{lll}
\hline Fatores & $\mathrm{N}^{\circ}$ & $\circ$ \\
\hline Governos federal e estadual & 7 & 36,8 \\
Governantes locais & 6 & 31,6 \\
Usuários & - & - \\
Prestadores de serviço & - & - \\
Profissionais de saúde & - & - \\
Crise ou eventos dramáticos & - & - \\
Outros & 6 & 31,6 \\
\hline Total* & $19^{*}$ & 100,0 \\
\hline
\end{tabular}

* o número total de informes não é necessariamente igual ao número de fatores que os tornaram relevantes porque mais de um fator pode interagir simultaneamente.

As Tabelas 13 e 14 mostram que os governantes locais, seguidos dos outros niveis de governo e de outros fatores - Projeto UNI e GERUS trouxeram para o CMS propostas de mudanças de infra-estrutura e do modelo assistencial, sendo que pouco menos da metade foi implementada. 
Tabela 13 - Fatores que tornaram relevantes os assuntos ligados a mudanças de infra-estrutura e do modelo assistencial discutidos no Conselho Municipal de Saúde, no periodo de 1993 e 1996, em Marília-SP.

\begin{tabular}{lll}
\hline Fatores & $\mathrm{N}^{\circ}$ & $\%$ \\
\hline Governos federal e estadual & 5 & 29,4 \\
Governantes locais & 8 & 47,1 \\
Usuários & 1 & 5,9 \\
Prestadores de serviço & - & - \\
Profissionais de saúde & - & - \\
Crise ou eventos dramáticos & - & - \\
Outros & 3 & 17,6 \\
\hline Total & 17 & 100.0 \\
\hline
\end{tabular}

Tabela 14 - Destino dado aos assuntos ligados a mudanças de infra-estrutura e do modelo assisicncial que entraram na agenda do Conselho Municipal de Saúde, no período de lo9: a 1996 - Marília-SP.

\begin{tabular}{lll} 
Destino & $N^{\circ}$ & $\%$ \\
\hline Descartado & - & - \\
Permanecem na agenda & 9 & 52,9 \\
Priorizados & 8 & 47,1 \\
\hline Total & 17 & 100,0 \\
\hline
\end{tabular}

$\dot{E}$ necessário registrar que esses assuntos nem sempre foram colocados de forma sistematizada. Em geral não se constituíam verdadeiramente em "propostas de ação", transformando-se muitas vezes em manifestações de intenção. Às vezes os mesmos assuntos surgiam, eram desconsiderados e novamente reapareciam em outros momentos e contextos.

Comparando o periodo de 1991 a 1992 com o periodo que estamos analisando, de 1993 a 1996, verifica-se que o número absoluto de assuntos relacionados a mudanças de infra-estrutura e do modelo assistencial foi menor em 93-96, mesmo correspondendo a período de quatro anos; ou seja, discutiu-se menos esse tema no Conselho. Na Figura 5 comparamos as influências que os diferentes niveis de governo exerceram no surgimento dessas propostas, e na Figura 6, o destino dado às mesmas, nos dois periodos. 


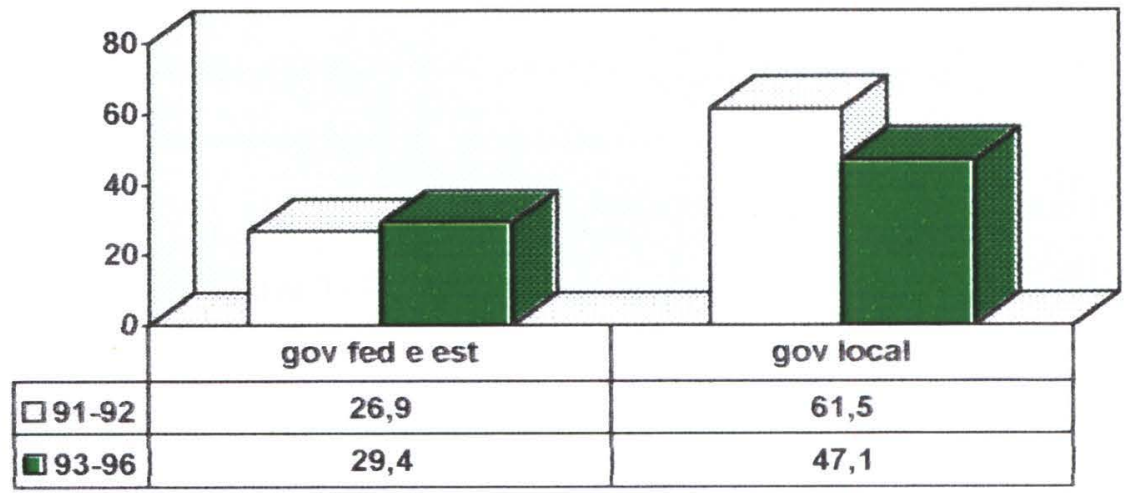

Figura 5 - Comparação entre as freqüências com que os governos federal/estadual e o governo local trouxeram assuntos gerenciais e assistenciais relacionados a mudanças de infra-estrutura e do modelo assistencial às reuniões do Conselho Municipal de Saúde, períodos de 1991-1992 e de 1993-1996 - Marília-SP (em \%).

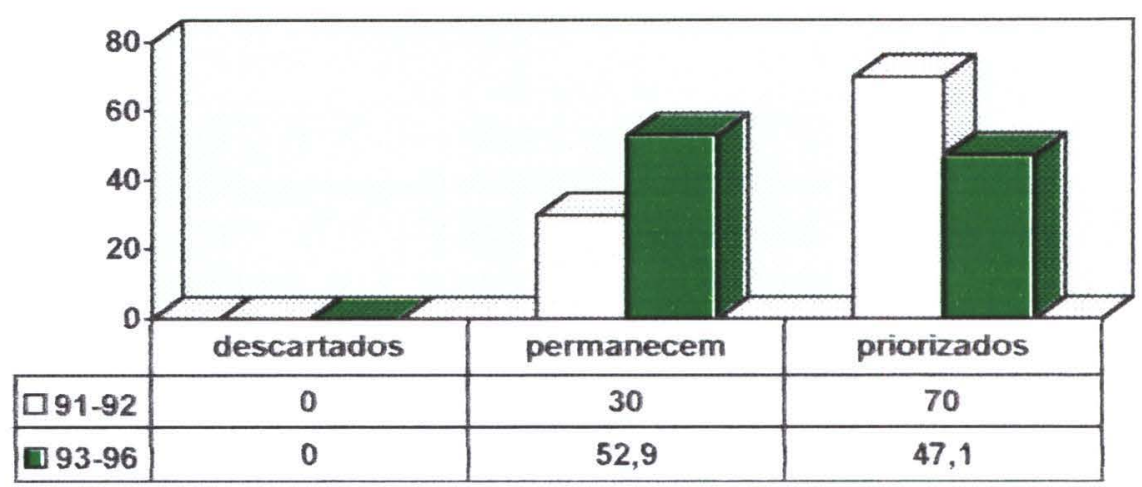

Figura 6 - Comparação entre as freqüências do destino dado aos assuntos gerenciais e assistenciais relacionados a mudanças de infra-estrutura e do modelo assistencial que surgiram nas reuniões do Conselho Municipal de Saúde, nos períodos de 1991-1992 e de 1993-1996 - Marília-SP (em \%).

Esses achados sugerem que diminuiu o espaço de formulação do poder local. Os governantes locais propõem menor número de alternativas para mudança dos modelos de gerência e assistência, como se evidencia na Figura 5, e, vê-se, na Figura 6, que essas propostas são implementadas com menor freqüência do que no período anterior. 
Isso fica mais evidente se analisarmos, separadamente, o destino dado aos assuntos tornados relevantes pelos governantes locais e pelos outros níveis de governo, como mostramos na Figura 7. As propostas de mudança surgidas por influência dos outros niveis de governo foram implementadas em $100 \%$ e $60 \%$ das vezes, enquanto as apresentadas pelos governantes locais o foram em $62,5 \%$ e $25 \%$, nos períodos de 1991-1992 e 1993-1996, respectivamente.

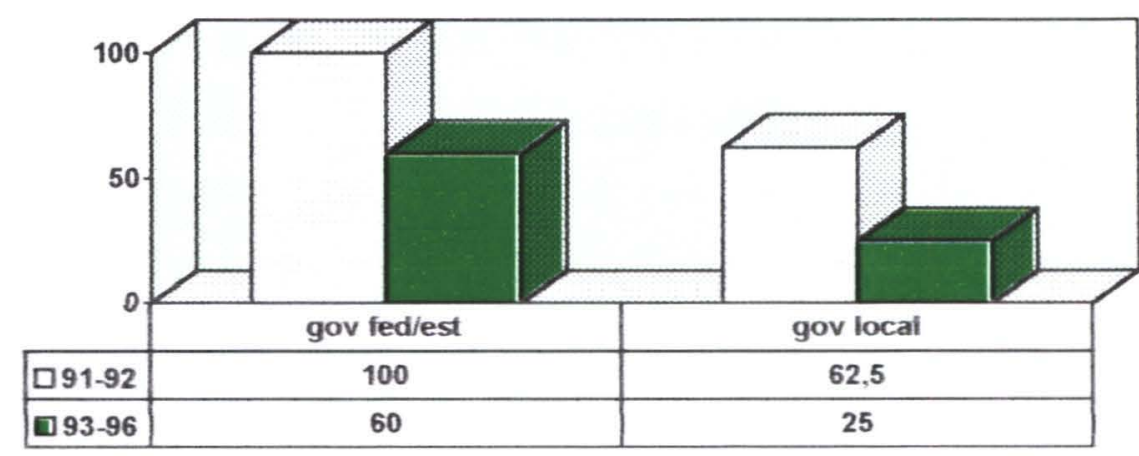

Figura 7 - Comparação entre as freqüencias dos assuntos gerenciais e assistenciais relacionados a mudanças de infraestrutura e do modelo assistencial priorizados (implementados) que surgiram nas reuniões do Conselho Municipal de Saúde por influência dos governos federal/estadual e governo local, nos periodos de 1991-1992 e 1993-1996 - Marília-SP (em \%)

Os achados são meros indícios de delimitação dos limites do poder local, não podendo ser considerados isoladamente do contexto nacional e local em que estava ocorrendo o processo de municipalização da saúde. São sugestivos, no entanto, da pouca autonomia do poder local nesse periodo.

Evidencia-se a dificuldade do CMS decidir pela implementação das propostas discutidas. Apesar dos assuntos surgidos não serem descartados, a maioria não era encaminhada para implementação. Enquanto no período anterior os governantes locais traziam mais assuntos para a agenda do CMS 
e conseguiam encaminhar maior número deles para implementação, nesse período (1993-1996) número maior de assuntos permaneceu na agenda. Pode-se inferir, mesmo sem chegar a conclusōes definitivas, que a baixa governabilidade dos dirigentes locais, cujas causas foram referidas anteriormente, quando do relato da percepção dos atores, contribuíram para ampliar as dificuldades de encaminhamento dos assuntos

\section{RECLAMAÇÕES E REIVINDICAÇÕES}

Esse grupo teve expressiva redução na sua freqüência em 19931996. quando comparado com o periodo anterior, como evidenciado na Figura 4 Diziam respeito, por exemplo, aos temas tais como exposição de dificuldades financeiras por administradores de hospitais conveniados ao SUS, falta de medicamentos para a população carente, não-cumprimento de horários por médicos e dentistas e falta de insumos e equipamentos nas UBS. Na tabela 15 mostramos a origem das reclamaçōes e reivindicaçōes que surgiram no CMS no periodo. Apesar do predominio de prestadores de serviço, também os usuários, os profissionais de saúde e as crises circunstanciais trouxeram esses assuntos ao CMS.

Tabela 15 - Fatores que tornaram relevantes os assuntos relacionados às reclamações sobre qualidade da assistência ou sobre remuneração dos serviços, discutidas no Conselho Municipal de Saúde, no periodo de 1993 a 1996 - MariliaSP

\begin{tabular}{lll}
\hline Fatores & $\mathrm{N}^{\circ}$ & $\%$ \\
\hline Governos federal e estadual & - & - \\
Governantes locais & 2 & 12,5 \\
Usuários & 4 & 25 \\
Prestadores de serviço & 7 & 43,8 \\
Profissionais de saúde & 1 & 6,3 \\
Crise ou eventos dramáticos & 2 & 12,5 \\
Outtros & - & - \\
\hline Total & $16^{*}$ & 100,0 \\
\hline
\end{tabular}

* o número total de assuntos não é necessariamente igual ao número de fatores que os tornaram relevantes porque mais de um fator pode interagir simultaneamente. 
Comparando o comportamento de usuários, prestadores de serviço e profissionais de saúde durante esse período (1993-1996) com o anterior, verifica-se, como mostramos na Figura 8 , que os prestadores de serviço reclamaram mais, proporcionalmente.

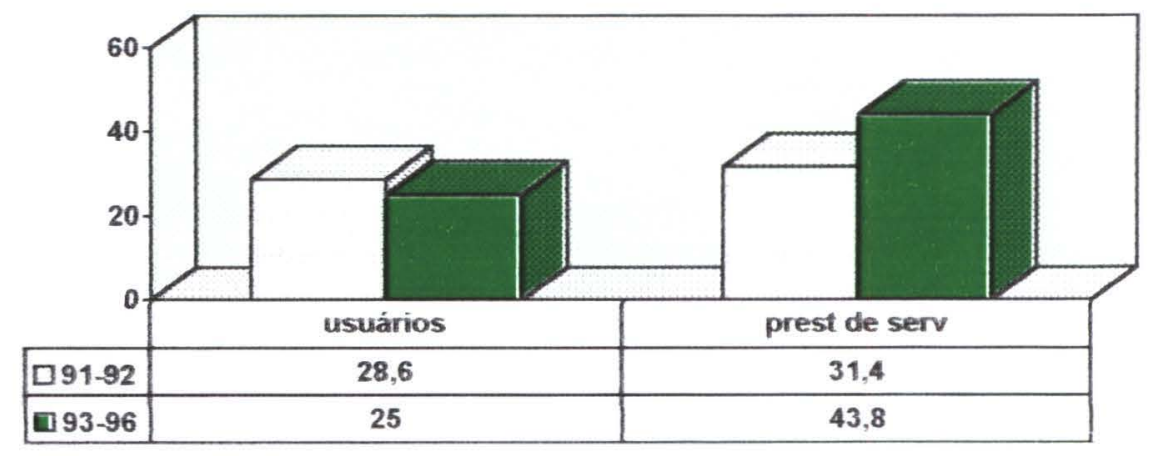

Figura 8 - Comparação entre as freqüências com que os usuários e prestadores de serviço trouxeram assuntos ligados a reclamações sobre qualidade da assistência ou sobre remunerações dos serviços nas reuniões do Conselho Municipal de Saúde, nos períodos de 1991-1992 e 19931996 - Marilia-SP (em \%)

O destino dado a esse grupo de assuntos é visto na tabela 16. A figura 9 compara esse período com o anterior. Verifica-se que o número de assuntos descartados diminuiu, mas isso não ampliou a solução das reclamações, já que a grande maioria permaneceu na agenda, não sendo priorizada. O CMS não teve poder para dar encaminhamento concreto às reclamações, da mesma forma que tinha ocorrido no período anterior.

Com respeito à redução do número de reclamações nesse período, pode-se inferir que isso ocorreu em virtude de os prestadores de serviço, usuários e outros atores locais do CMS perceberem a pouca autonomia desse fórum para encaminhar os assuntos. A expectativa gerada com a criação do CMS para a solução dos problemas frustou-se, pois a solução não veio para a grande maioria. Por esse motivo o CMS passou a ser menos 
utilizado para reclamações, podendo ser caracterizado como um fórum de discussão e não um fórum de decisão.

Tabela 16 - Destino dado às reclamações sobre qualidade da assistência ou sobre remuneração dos serviços que entraram na agenda do Conselho Municipal de Saúde, no período de 1993 a 1996 - Marília-SP

\begin{tabular}{lll}
\hline Destino & $\mathrm{N}^{\circ}$ & $\%$ \\
\hline Descartado & 1 & 7,7 \\
Permanecem na agenda & 11 & 84,6 \\
Priorizados & 1 & 7,7 \\
\hline Total & 13 & 100.0 \\
\hline
\end{tabular}

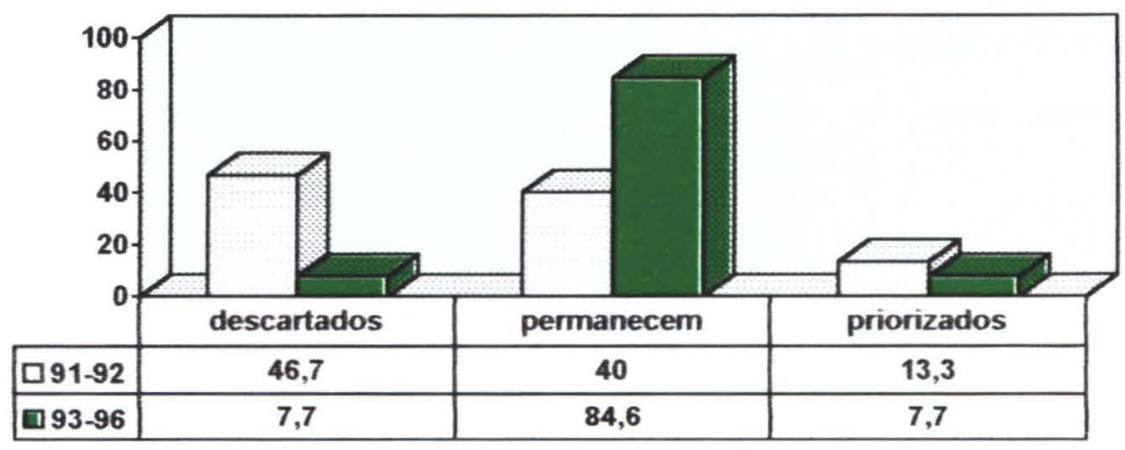

Figura 9 - Comparação sobre o destino dado às reclamações sobre qualidade da assistência ou sobre remuneração dos serviços que surgiram nas reuniões do Conselho Municipal de Saúde, nos períodos de 1991-1992 e 1993-1996 - Marília$\mathrm{SP}(\mathrm{em} \%)$.

\section{CAMPANHAS E PROGRAMAS DE SAÚDE NACIONAIS E ESTADUAIS}

Fizeram parte da agenda do CMS com a freqüência de 12\%, como se vê na Tabela 10. Diziam respeito a: combate ao vetor da dengue, prevenção à raiva, campanha nacional de multivacinação, campanhas de prevenção de AIDS etc.

O que tornam esses assuntos relevantes nas reuniões do CMS são, evidentemente, os governos federal e estadual, já que constituem campanhas preparadas por esses níveis de governo. O destino dado a esse grupo de assuntos é quase sempre o da priorização e implementação. Trata- 
se de projetos e programas "verticais", decididos centralizadamente. Os municipios constituem instâncias técnico-operacionais. São apoiados, geralmente, por recursos especificamente destinados pelas instâncias formuladoras.

AMPLIAÇÃO OU APERFEIÇOAMENTO DO CONTROLE SOCIAL

Corresponderam a $32,4 \%$ do total dos assuntos surgidos no CMS no período, como se verifica na Tabela 10. Foram mais freqüentes do que no periodo anterior, quando corresponderam a 23,6\%. Exemplos de assuntos classificados nesse grupo são: prestação de contas de recursos do Fundo Municipal de Saúde, realização de conferèncias de saúde, formação de conselhos locais de saúde, aprovação de credenciamento de serviços, cursos de capacitação de conselheiros etc.

O que os tornou relevantes é mostrado na tabela 17 , em que se observa amplo predomínio dos governos federal/estadual e governantes locais, em relação a esse item. Os fatores classificados como "outros" foram o projeto UNU/Marilia e a FAMEMA, que trouxeram assuntos desse grupo ao CMS quatro e três vezes, respectivamente.

Tabela 17 - Fatores que tornaram relevantes os assuntos relacionados à ampliação ou aperfeiçoamento do controle social discutidas no Conselho Municipal de Saúde, no periodo de 1993 a 1996 - Marília-SP.

\begin{tabular}{lll} 
Fatores & $\mathrm{N}^{\circ}$ & $\%$ \\
\hline Governos federal e estadual & 21 & 48,8 \\
Governantes locais & 15 & 34,9 \\
Usuários & - & - \\
Prestadores de serviço & - & - \\
Profissionais de saúde & - & - \\
Crise ou eventos dramáticos & - & - \\
Outros & 7 & 16,3 \\
\hline Total & $43^{*}$ & 100,0 \\
\hline
\end{tabular}

* o número total de assuntos não é necessariamente igual ao número de fatores que os tornaram relevantes porque mais de um fator pode interagir simultaneamente. 
A figura 10 compara os períodos 1991-1992 e 1993-1996. Os governos federal e estadual continuaram exercendo forte influência na formulação de políticas de ampliação ou aperfeiçoamento do controle social, como no período anterior; no último, porém, o governo municipal interferiu um pouco mais, ou seja, o governo local não se restringiu a colocar em pauta o que os governos centrais "ordenavam", mas foi além, procurando aperfeiçoar, com iniciativas próprias, as formas de participação.

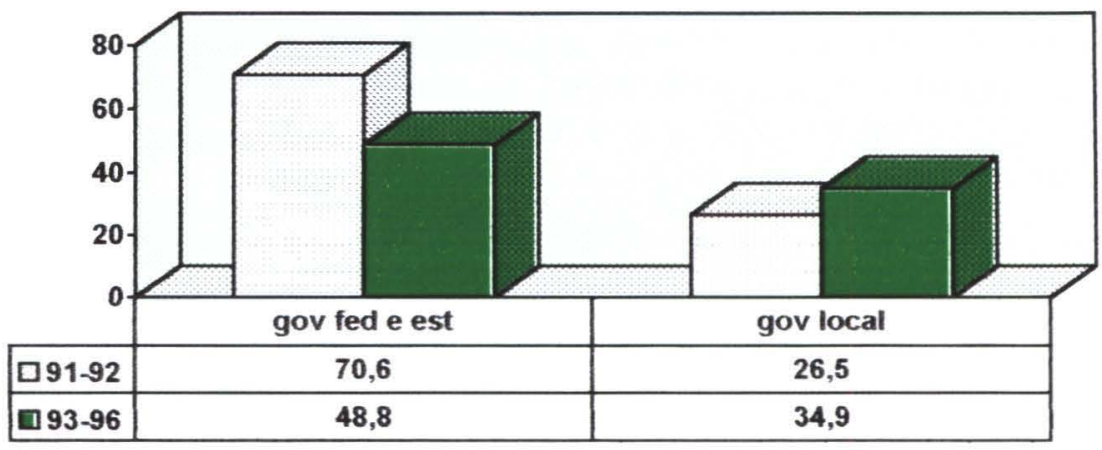

Figura 10 - Comparação entre a freqüência com que os governos federal/estadual e o governo local trouxeram assuntos relacionados à ampliação ou aperfeiçoamento do controle social nas reuniões do Conselho Municipal de Saúde nos períodos de 1991-1992 e 1993-1996 - Marília-SP (em $\%)$.

O destino dados a esses assuntos (Tabela 18 e Figura 11) mostra que foram implementados em sua expressiva maioria, em ambos os periodos.

Tabela 18 - Destino dado aos assuntos relacionados à ampliação ou aperfeiçoamento do controle social que entraram na agenda do Conselho Municipal de Saúde, no período de 1993 a 1996 - Marília-SP.

\begin{tabular}{lll}
\hline Destino & $\mathrm{N}^{\circ}$ & $\%$ \\
\hline Descartado & - & - \\
Permanecem na agenda & 4 & 11,4 \\
Priorizados & 31 & 88,6 \\
\hline Total & 35 & 100.0 \\
\hline
\end{tabular}




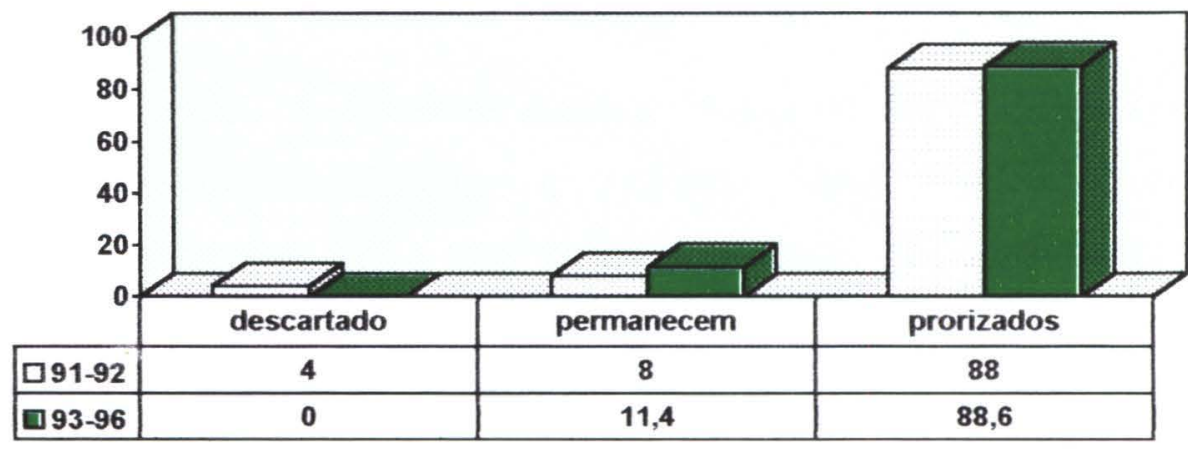

Figura 11 - Comparação sobre o destino dado aos assuntos relacionados à ampliação ou aperfeiçoamento do controle social que surgiram nas reuniões do Conselho Municipal de Saúde nos períodos de 1991-1992 e 1993-1996 - Marília-SP $(\mathrm{em} \%)$.

\section{SÍNTESE}

Com base nesses achados e informações podemos destacar o seguinte, a respeito do CMS no período de 1993 a 1996 :

(1) Um dos papéis do CMS continuou sendo, como no periodo anterior, constituir-se em canal de transmissão de informações, utilizado principalmente pelos poderes formais de governo e por algumas instituições acadêmicas.

(2) As propostas de mudança dos modelos gerencial e assistencial foram menos freqüentes e implementadas em menor número do que no período anterior. Isso se deveu, provavelmente, à menor capacidade de resposta do governo local no período de 1993 a 1996.

(3) O poder local, como instância de implementação de políticas formuladas nas outras instâncias de poder, foi bem sucedido no encaminhamento da execução de campanhas e programas sanitários e no avanço da institucionalização da participação popular e controle social. Nesse último caso, inclusive, o poder local passou a formular políticas adicionais com 
a finalidade de aperfeiçoar a participação e o controle, provavelmente por influência do Pro-UNI.

(4) a solução de demandas de usuários e prestadores de serviço, colocadas sob a forma de reivindicações e reclamações, mesmo quando consideradas pertinentes, não tiveram, em geral, possibilidade de encaminhamentn por esse processo político, em virtude da fragilidade e da falta de autonomia do poder local. Isso ocasionou também redução da pressão exercida por esses atores no CMS, o que se deveu, provavelmente, à maior visibilidade da fraqueza do CMS como instância decisória.

\subsubsection{Conselhos Locais de Saúde}

A formação dos Conselhos Locais de Saúde (CLS) teve grande influência do projeto UNI-Marilia. O apoio à sua constituição foi uma das estratégias de desenvolvimento do componente Comunidade. Foram sendo criados a partir de 1994. Foram analisadas sete atas dos seguintes CLS:

1. CLS do PAS Santa Antonieta

2. CLS da UBS São Judas

3. CLS da UBS Bandeirantes

4. CLS da UBS Altaneira

5. CLS da UBS Vila Coimbra

6. CLS da UBS Aeroporto

7. CLS da UBS Castelo Branco

Esses conselhos realizaram, nesse período, 100 reuniões e trataram de 213 assuntos. A distribuição das reuniões e o total de assuntos analisados encontram-se na tabela 19 
Tabela 19 - Número de reuniões e de assuntos discutidos nas reuniões dos Conselhos Locais de Saúde de 7 (sete) Unidades de Saúde no periodo de 1993 a 1996 - Marilia-SP

\begin{tabular}{lll}
\hline Unidade de Saúde & $\mathrm{N}^{\circ}$ de reuniões & $\mathrm{N}^{\circ}$ de assuntos \\
\hline Santa Antonieta & 12 & 27 \\
São Judas & 23 & 51 \\
Bandeirantes & 19 & 46 \\
Altaneira & 3 & 4 \\
Vila Coimbra & 27 & 53 \\
Aeroporto & 12 & 23 \\
Castelo Branco & 4 & 9 \\
\hline Total & 100 & 213 \\
\hline
\end{tabular}

Fonte: Atas dos CLS

Os regimentos internos dos CLS eram geralmente divididos em tópicos que se referiam à definição do Conselho e determinavam sua composição e estrutura e a competência de sua atuação. O da UBS Coimbra, para exemplificar, è sintetizado a seguir

Definição do Conselho: É uma equipe formada por membros da Comunidade e do Serviço. Tem caráter deliberativo, normativo, fiscalizador e consultivo com relação às questões de saúde da área de abrangência da UBS Vila Coimbra.

Composição: O Conselho será composto pelo Presidente, por quatro membros titulares (da Comunidade e dos Serviços - quatro de cada) e quatro suplentes (da Comunidade e dos Serviços - também quatro de cada). O mandato será de 2 (dois) anos com direito à reeleição de $50 \%$ dos seus membros, quaisquer que sejam. A Comunidade elege seus representantes e os Serviços, os seus. O Presidente é eleito pelos membros. Todos os presentes (titulares e suplentes) terão direito a voto, desde que haja número paritário entre os suplentes também. Os restantes não têm direito a voto.

Competência do Conselho: (1) identificar os problemas da área de abrangência e buscar solução para os mesmos; (2) discutir o funcionamento da UBS; (3) realizar debates - com base nas informaçōes de morbimortalidade; (4) realizar reuniōes periódicas uma por mês; (5) procurar, junto aos órgāos competentes, soluçāo para os problemas levantados; (6) trazer problemas da comunidade; (7) trazer problemas dos serviços 
$\mathrm{Na}$ composição dos CLS, estabeleceu-se que os seus membros teriam metade de usuários e metade de representantes da UBS. O regimento interno do CLS da UBS Coimbra têm uma falha em sua redação, ao propugnar a escolha do presidente entre os seus 16 membros (quatro titulares e quatro suplentes dos serviços e da comunidade) e discriminar em sua composição o presidente do CLS como sendo um membro a mais. Na prática o que se observou nos diversos CLS foi a utilização do critério de paridade e o presidente habitualmente era um dos componentes do segmento serviços, sendo geralmente o coordenador da UBS. A paridade em conselhos locais não é uma prática comum, pois è aplicada habitualmente apenas aos conselhos municipais de saúde Para os CLS, o número de participantes da Comunidade costuma ser limitado apenas pelo interesse dos moradores da área de abrangência em partıcipar. Essa paridade foi extinta no ano de 1997 , sendo substituida por no minimo $50 \%$ de representantes da comunidade. O número médio de partıcıpantes nas reuniōes, que registraram sua presença nas atas, foi de 9,8 pessoas.

A distribuição dos assuntos é mostrada na tabela 20. 
Tabela 20 - Distribuição dos assuntos que surgiram nas reuniões dos CLS das UBS Santa Antonieta, São Judas, Bandeirantes, Altaneira, Vila Coimbra, Aeroporto e Castelo Branco, realizadas no período de 1993 a 1996 - Marilia-SP.

\begin{tabular}{|c|c|c|}
\hline Tipo de assunto & $\mathrm{N}^{\circ}$ & $\%$ \\
\hline Relacionados à divulgação de informações & & \\
\hline conselheiros/usuários & 48 & 22,5 \\
\hline Reclamações e reivindicações relacionadas à UBS & 47 & 22,1 \\
\hline $\begin{array}{l}\text { Estudo de clientela e ligados a mudanças do modelos gerencial } \\
\text { e assistencial; reflexües sobre o processo saúde/doença e }\end{array}$ & & \\
\hline problemas de saúde da área de abrangência & 32 & 15,0 \\
\hline Reclamações e reivindicações relacionadas à demanda & & \\
\hline reprimida na assistência básica e especializada & 25 & 11,7 \\
\hline $\begin{array}{l}\text { Relacionados à mobilização da população para a soluçào de } \\
\text { problemas de bairros (mutirões) }\end{array}$ & 19 & 8,9 \\
\hline $\begin{array}{l}\text { Relacionados a sugestões dos conselheiros/usuários aos outros } \\
\text { membros do CLS }\end{array}$ & 16 & 7,5 \\
\hline Regimentais & 15 & 7 \\
\hline Ligados à desmotivação dos conselheiros à participar & 7 & 3,3 \\
\hline $\begin{array}{l}\text { Justificativa dos gestores (locais ou municipais) às reclamaçōes } \\
\text { dos conselheiros/usuários }\end{array}$ & 4 & 1,9 \\
\hline Total & 213 & 100,0 \\
\hline
\end{tabular}

Fonte: atas dos CLS.

Pela análise das freqüências com que surgiram nas reuniões verificou-se o seguinte:

1. Os CLS foram utilizados muitas vezes para que os gestores transmitissem informações aos usuários. Esses temas corresponderam a $22,5 \%$ do total de assuntos tratados.

2. Os usuários utilizaram-se desse canal para reclamar e reivindicar. Se somarmos os assuntos referentes a reclamações e reivindicações da UBS (infra-estrutura), equivalentes a $22,1 \%$, com os referentes à demanda reprimida, $11,7 \%$, este tema foi o mais freqüente, tendo correspondido a $33,8 \%$ do total.

3. $15 \%$ dos assuntos disseram respeito a reflexões e propostas sobre os modelos gerencial e assistencial. 
4. A mobilização da população para solucionar problemas dos bairros da área de abrangência, caracterizando tipo bem específico de participação comunitária, já analisado no capítulo 2 , teve freqüência significativa, com $8,9 \%$ do total.

5. Os assuntos que tiveram como origem os conselheiros-usuários corresponderam a $7,5 \%$ dos assuntos discutidos.

A análise dos assuntos mais comuns, mostrada a seguir, contribuiu para a compreensão do papel dos CLS no processo decisório das políticas locais de saúde no periodo.

\section{DIVULGAÇÃO DE INFORMAÇÕES AOS CONSELHEIROSIUSUÁRIOS}

Esse grupo constituiu 22,5\% da agenda dos CLS, refletindo a preocupação de instituir uma forma de participação que tem como alvo a capacitação e a transmissão de informações aos usuários. Embora tendo essa intenção, verifica-se que sua operacionalização não se dá de forma sistematizada. Os assuntos surgem por "estimulos" diversos, pois o que os torna relevantes para a agenda do CLS são geralmente externos à Unidade Básica de Saúde, devendo ser assinalados:

(1) realização de campanhas de vacinação, combate ao vetor do dengue, etc. Esses eventos são aproveitados pelos CLS para ressaltar a importância de vacinar, promover mobilização contra o dengue, etc.;

(2) pré-conferências ou conferências de saúde, normas operacionais novas, etc. Constituem tópicos de discussão em que os "experts" transmitem informações sobre esses temas; 
(3) eventos da saúde, tais como Feira da Saúde, Semana da Criarça e Bebe-Clínica;

(4) divulgação de cursos de capacitação para conselheiros e utilização das reuniões do CLS para convidar os presentes para participar;

(5) palestras sobre problemas de saúde da área e doenças de elevada prevalência - hipertensão e diabetes, por exemplo -, com ênfase na prevenção.

Percebe-se que o "fluxo" se dá dos que detêm o saber, que são os técnicos em saúde ou alguns experts em assuntos específicos, para os que não os detêm. A assimilação desse saber, ou seja a eficácia dos CLS em transmitir informações, e sua influência no processo de mudanças das políticas locais são assuntos ainda em aberto, para os quais serão realizadas inferências mais adiante. O número reduzido de presentes às reuniões certamente limita a avaliação do alcance e da efetividade dessas medidas.

\section{RECLAMAÇÕES RELACIONADAS ÀS UBS}

Compreenderam $22,1 \%$ do total e estiveram ligados a temas relacionados a: (1) estrutura física inadequada de UBS; (2) solicitação de telefone comunitário; (3) falta de medicamentos; (4) falta de conforto para usuários e funcionários; (5) falta de material de consumo; (6) não cumprimento de horários pelos funcionários etc.

Constituem elementos de pressão dirigidos geralmente à Secretaria de Saúde. Estabelece-se quase sempre uma aliança entre conselheirosgestores e conselheiros-usuários e, portanto, o fluxo é entre o CLS e outros niveis de poder. A efetividade dessa pressão política revelou-se, além de reduzida, bastante variável, na dependência do tipo de assunto e do grau de 
pressão. A baixa governança do governo municipal em um contextっ de grande demanda por investimentos foi um dos fatores para o pouco atendimento a essas reivindicações. Isso, em muitas reuniões, gerou descontentamento e desmotivação.

ESTUDO DE CLIENTELA E LIGADOS A MUDANÇAS DOS MODELOS GERENCIAL E ASSISTENCIAL; REFLEXÕES SOBRE O PROCESSO SAÚDE/DOENÇA E PROBLEMAS DE SAÚDE DA ÁREA DE ABRANGÊNCIA

Correspondendo a $15 \%$ do total de assuntos, esse grupo refere-se a temas como: (1) estudos epidemiológicos da área de abrangência; (2) diretrizes de planejamento de gestão; (3) regionalização nos processos de gestão e assistência.

Representaram, em geral, momentos de reflexão crítica e análise de propostas de mudança do modelo de saúde tradicional, tornada relevante por "experts". Os CLs não se constituíram em arena com capacidade de formulação sistematizada de medidas de planejamento. Seus componentes não expressavam discordância com as propostas de mudança. Essas, no entanto, constituiam apenas "intenções" e não projetos suficientemente viáveis para envolver as unidades básicas de saúde na sua operacionalização, oferecendo as condições necessárias e incorporando-as, de fato, como sujeitos de mudança do modelo de saúde vigente.

RECLAMAÇÕES RELACIONADAS À DEMANDA REPRIMIDA NA ASSISTÊNCIA BÁSICA E ESPECIALIZADA

Esse grupo, embora semelhante ao de "reclamações relacionadas às UBS", tem uma característica que o diferencia: a relação entre a oferta e a demanda no modelo assistencial vigente. Corresponderam a $11,7 \%$ do total e apareceram na agenda da seguinte forma: (1) filas e demora no atendimento de consultas médicas básicas - clínica geral, pediatria e ginecologia/obstetrícia - ou odontológicas; (2) demora no agendamento de consultas nos outros niveis de atenção (especializadas); (3) tentativas de 
alteração nas formas de agendamento para reduzir esperas; (5) zrises ocasionadas por situações particulares, nas quais um atendimento de urgência não foi efetuado ou um encaminhamento não foi feito, gerando danos ou riscos ao paciente; (6) queixas sobre grosserias e atendimentos muito rápidos etc.

RELACIONADOS À MOBILIZAÇÃO DA POPULAÇÃO PARA A SOLUÇÃO DE PROBLEMAS DE BAIRROS (MUTIRÕES)

Nesse grupo, que representou $8.9 \%$, estão as medidas discutidas e eventualmente implementadas, nas quais a preocupação foi a de mobilizar a comunidade para resolver problemas. As iniciativas partiam tanto de conselheiros/gestores quanto de conselheiros/usuários. Exemplos mobilização para providenciar reparos na UBS; (2) mobilização para obter doadores criando ou aderindo à "semana de doação de sangue"; (3) arrecadação de medicamentos sem uso; (4) mobilização para reativar equipamentos públicos de lazer e esportes; (5) mobilização para ajuda social a familias carentes com problemas graves de saúde em algum de seus membros.

RELACIONADOS A SUGESTÕES DOS CONSELHEIROSIUSUÁRIOS AOS OUTROS MEMBROS DO CLS

Correspondendo a $7,5 \%$ do total de assuntos, esse grupo tem fluxo usuário-gestor. Ou seja, o que os tornou relevantes e os incluiu na pauta de discussões do CLS é a comunidade. Apresentaram-se da seguinte forma: (1) preocupação com prostituição e consumo de bebida e drogas por menores; (2) preocupação com o Centro Comunitário da área; (3) preocupação com a segurança pública no bairro; (4) reivindicação de reforma do centro poliesportivo; (5) preocupação com esgoto a "céu aberto": (6) preocupação com destino inadequado do lixo urbano. 
Alguns estudos realizados em Marilia procuraram analisar o papel dos Conselhos Locais de Saúde durante esse periodo. O projeto UNI-Marilia, em seu relatório anual do $2^{\circ}$ ano (Projeto UNI-Marilia ${ }^{* 6} 1995$, p. 83-88) realizou pesquisa com um grupo de 23 conselheiros, aparentemente todos usuários, escolhidos aleatoriamente, obtendo os seguintes resultados:

(1) $52 \%$ dos conselheiros consideraram que os individuos adoeciam em decorrência de sua situação sócioeconômica;

(2) $56 \%$ entendiam que o papel dos conselhos era o de resolver os problemas de saúde da unidade de saúde, e $22 \%$ que era o de contribuir para a melhoria de saúde da comunidade;

(3) questionados sobre as dificuldades de atuação dos CLS, 35\% consideravam que essas se deviam a não receberem respostas das autoridades, enquanto $22 \%$ disseram que quando conseguiam respostas, elas demoravam muito;

(4) $65 \%$ dos entrevistados colhiam informações sobre os problemas da comunidade, conversando e ouvindo as pessoas, e $17 \%$ através de visitas a áreas de risco;

(5) $65 \%$ conheciam o Conselho Municipal de Saúde, mas nảo conheciam seus representantes nesse fórum.

Estudando a participação comunitária no projeto UNI-Marilia, LÓPEZ ${ }^{62}$ (1996), em sua dissertação de mestrado, traz informações sobre esse tema. Para os propósitos deste estudo interessa-nos focalizar mais particularmente alguns aspectos dessa pesquisa que contribuem para analisar a influência dos CLS no processo decisório. Essa autora refere-se em diversas ocasiões às dificuldades de encaminhamento das queixas, reivindicações e reclamações oriundas dos CLS. Os problemas que não pudessem ser resolvidos na própria UBS deveriam ser encaminhados para o Conselho Municipal de Saúde, segundo decisão tomada pelo próprio CMS em janeiro de 1995. Isso raramente ocorria, por não existirem mecanismos que facilitassem esse fluxo. Não existiam mecanismos institucionalizados para o encaminhamento dos problemas. As reivindicações das UBS, quando valorizadas, eram tratadas de forma individualizada, por esforços de 
lideranças ou de chefias de serviços, intermediando soluções diretamente na Secretaria de Saúde e, portanto, favorecendo práticas de clientelismo.

Os estudos dessa autora reafirmaram a pouca capacidade de resposta da Secretaria Municipal de Saúde às reivindicações. Diz ela: "É interessante observar o quanto os CLS conseguiriam expressar e manter independência através de divergências articuladas, ainda que com graus escassos de articulação. Segundo a perspectiva da Secretaria de Saúde não existe uma 'divergência' de fundo entre os CLS e a mesma, e este seria um 'mau sinal'. O que estaria acontecendo é que os Conselhos Locais 'estão em uma fase de reivindicações' e a Secretaria de Saúde não tem suficiente autonomia econômica para atender tal demanda; aparecem, assim, como divergência com a comunidade, situações que na realidade são fruto de sua incapacidade de resposta" (p.151).

\section{AVALIAÇÃO DA INFLUÉNCIA DOS CLS NO PROCESSO DECISÓRIO}

A análise da atuação dos CLS durante esse periodo permite evidenciar a pouca influência que esse fórum exerceu no processo decisório das politicas locais de saúde. Comparando o papel desses conselhos com o Conselho Municipal de Saúde, há, segundo nosso ponto de vista, algumas semelhanças, entre as quais devem ser ressaltadas:

(1) assim como o CMS, os CLS contribuiram para a ampliar o alcance de campanhas e programas sanitários. Quanto aos CMS, ocuparam 11,2\% do total de assuntos abordados. Nos CLS, essa freqüência não foi obtida de forma individualizada, mas é também um assunto freqüente;

(2) ambos os conselhos tiveram dificuldade de encaminhar a solução das demandas dos atores políticos locais referentes a reivindicações e reclamações que exigiam investimentos, em virtude da falta de autonomia e governança locais. 
Existiam grandes expectativas com a formação dos conselhos locais de saúde. Em documento do Projeto UNI-Marilia (1995, p.82), essas expectativas estavam assim explicitadas: "Considera-se que esses conselhos contribuirão para a gestão descentralizada das Unidades Básicas de Saúde e constituirão um modelo de participação da comunidade no setor saúde, além de contribuirem com o Conselho Municipal de Saúde na gestão de política municipal para o setor".

É difícil avaliar, durante periodo tão curto, a influência dos CLS na gestão descentralizada das unidades de saúde e no sistema de saúde como um todo. Não nos podemos esquecer do caráter processual de democratização de gestão e avanços nesse sentido, mesmo que pequenos, podem ter tido significado importante. É possivel perceber, no entanto, que as UBS não adquiriram, ao menos até essa época, condição de gestão autônoma e os CLS constituíram-se em uma instância praticamente destituida de poder. As demandas que surgiram nos CLS foram transferidas de forma não sistematizada para o poder executivo e para o Conselho Municipal de Saúde.

Essas "arenas políticas", por sua vez, também tinham poder de decisão e capacidade de solução das demandas apresentadas bastante limitada. Podemos observar, como já mencionamos, que a capacidade de resposta dessas arenas depende do tipo de assunto. $\mathrm{Na}$ situação de fragilidade do poder local e da dificuldade em dar resposta aos "problemas" da saúde, que caracterizou esse periodo, os assuntos que exigiam investimentos e mudanças mais profundas nos modelos gerencial e assistencial não tiveram encaminhamento adequado.

As dificuldades de resposta do poder local às reivindicações por mudança, reclamadas nos conselhos locais de saúde, não chegaram a gerar conflitos entre os atores. Muitas vezes, ao contrário, serviam para amenizar 
situações conflituosas entre os governantes locais e os usuários que reclamavam por melhorias. O registro abaixo mostra esse tipo de situação:

A participação da comunidade é uma coisa muito distorcida ... . Nas primeiras reuniões com a Comunidade (nos CIS) faziam criticas, por exemplo, da falta de medicamentos, falta de médicos. Mas quando você fala de toda dificuldade de licitação, contratar pessoas, fazer concursos, recrutar pessoas ... publicar, fazer a prova, esperar tempo pra recursos. Então ela falava: Há! mas é assim. Porque na interpretação deles o médico estava a disposição. Chega lá e põe ele. Mas não é bem assim (Gestor 4).

Os CLS amenizavam situações de tensão e tiveram também a função pedagógica de expor aos conselheiros os limites do poder local na solução dos problemas de saúde. Os assuntos que podiam ser encaminhados dentro desses limites seguiam adiante. Outros, situados fora dos mesmos, eram descartados ou encaminhados a outros processos politicos.

É necessário considerar que a influência dos CLS depende não só da dimensão do poder local, mas também da sua legitimação como fórum de decisão pelos governantes locais. Ou seja, os CLS precisam ser valorizados como instâncias de decisão por esses governantes, para que se constituam verdadeiramente em espaços de poder, mesmo que limitados pelas dificuldades estruturais que conformam o poder local. Estes fóruns, por não serem legitimados pelos níveis de decisāo superiores, na prática foram atores com poder meramente "virtual".

O estímulo que os atores locais deram para a criação de CLS em Marilia foi bem visivel, especialmente por intermédio do projeto UNI-Marilia. Estimularam-se e capacitaram-se lideranças comunitárias e, com o apoio do projeto, os três parceiros - comunidade, serviços de saúde e academia investiram esforços de forma sistematizada em sua criação, como comprovam os documentos de avaliação do projeto. A institucionalização dos CLS como instâncias de decisão e influência não se deu, no entanto, de maneira satisfatória. Para isso haveria necessidade não só de esforços para 
a sua criação, mas também para a sua inserção nos mecanismos decisórios, o que acabou não se verificando por causa das dificuldades já referidas.

É importante registrar que, apesar de restrita, a influência do CLS ocorreu. Ou seja, sua criação não foi inócua. Essa influência deu-se no âmbito de algumas politicas regulatórias, ligadas à construção de um incipiente controle sobre o funcionamento das UBS. Propiciou também, mesmo que não tenhamos elementos para analisar sua eficácia, o desenvolvimento de ações de educação em saúde e de ampliação do que costumamos chamar "consciência sanitária". 


\subsection{Periodo de 1997 a 1999}

Com a mudança na administração municipal, como decorrência das eleições de 1996, retornou ao comando do governo o mesmo prefeito, do PMDB, do período de 1983 a 1988. A aliança político-eleitoral que garantiu a sua vitória teve a participação de amplo segmento dos "aliados do movimento sanitário". Esses atores, que exerceram grande influência nos rumos da municipalização da saúde, em sua fase inicial, passaram nesse periodo a constituir o núcleo central do poder formal da Secretaria de Saúde, com a escolha de uma de suas lideranças para ser o novo secretário.

Esse, por sinal, juntamente com alguns de seus principais assessores, teve participação direta em muitos acontecimentos relevantes ocorridos nos últimos anos e relacionados a mudanças no sistema de saúde e nas práticas de ensino para os profissionais de saúde ocorridos em Marilia. Entre esses sobressaem o projeto UNI-Marilia e as mudanças no processo de formação de profissionais de saúde. A FAMEMA, por exemplo, desde meados da década de 1990 planejava alterações curriculares no seu curso de medicina. Essas mudanças, consideradas bastante inovadoras e que ficaram conhecidas como "Aprendizado Baseado em Problemas" (ou PBL em inglês), foram implementadas a partir de 1997.

Uma das primeiras estratégias adotadas pelos novos governantes da saúde foi preparar o município de Marilia para habilitar-se à "gestão plena do sistema municipal", a forma mais avançada de gestão municipalizada da NOB SUS 01/96, publicada no ano anterior e que ainda não estava em vigor. Como já mencionamos, o fato de Marilia estar na gestão parcial e não na semiplena, na norma presentemente em vigor (NOB SUS 01/93), incomodava os gestores que tinham como prioridade ampliar sua autonomia na gestão da saúde, pois isso era indispensável para a implementação das mudanças que julgavam necessárias 
Entre as medidas tomadas para habilitar-se à gestão plena do sistema municipal, assim que a nova norma operacional fosse implementada, podem ser destacadas: (1) criação da "Divisão de Avaliação, Controle e Auditoria" (MARÍLIA $^{73}$, 1998), com o objetivo de ampliar a capacidade de reprogramação e de regulação dos serviços realizados; (2) criação de instrumentos de informação que facilitassem a gerência e a mudança do modelo assistencial, como a implantação de Sistema de Informações em Mortalidade (SIM), Sistema de Informação de Nascidos Vivos (SINASC), Sistema de Informaçōes de Agravos de Notificaçāo de Vigilância Epidemiológica (SINAM); (3) readequações no Fundo Municipal de Saúde (MARILIA $\left.{ }^{73,75}, 1998\right)$.

Outro requisito obrigatório para que o municipio assumisse a gestão plena foi a aprovação do Plano Municipal de Saúde (PMS) pelo Conselho Municipal de Saúde. O PMS, aprovado em 18 de agosto de 1997, tinha as seguintes prioridades para o periodo de 1997 a 2000:

(I) Desenvolver as bases territoriais de atuação das UBS;

(II) Definir políticas voltadas para o desenvolvimento dos recursos humanos da Secretaria Municipal de Higiene e Saúde;

(III) Construir e implementar um modelo de atenção voltado para a vigilância à saúde :

(IV) Implantar o sistema de avaliação por desempenho

Diretrizes de planos municipais de saúde elaboradas no início da gestão costumam ser revistas e readequadas ao longo do periodo de governo. Como já comentamos, costumam representar "intenções" dos governantes e tanto os obstáculos administrativos do "dia-a-dia", como aspectos contextuais e conjunturais influem para a revisão das diretrizes estabelecidas. Um exemplo foi a IV Conferência Municipal de Saúde (MARÍLIA ${ }^{74}$, 1998), realizada em maio de 1998, que ocasionou algumas revisões no plano elaborado no ano anterior. 


\subsubsection{O município em condição de gestão plena do sistema municipal}

O pleito de habilitação à gestão plena é aprovado pelo CMS no dia 17 de fevereiro de 1998 e no dia $1^{\circ}$ de junho do mesmo ano o municipio de Marilia foi habilitado a essa forma de gestão. Passou, a partir dessa habilitação, a receber repasses de recursos federais do Fundo Nacional de Saúde (FNS) para o Fundo Municipal de Saúde (FMS). Esses recursos correspondiam a R\$8.457.572,63 (oito milhões, quatrocentos e cinquenta e sete mil, quinhentos e setenta e dois reais e sessenta e três centavos) por ano. Nesses valores estavam incluidos o Piso da Atençāo Básica (PAB) os destinados a pagar os procedimentos ambulatoriais mais complexos $\boldsymbol{e}$ as internações hospitalares, o incentivo a programas especificos, taıs como o Programa de Saúde da Familia (PSF), o Programa de Agentes Comunitarios de Saúde (PACS), o Programa de Combate às Carências Nutricionais (PCCN) e os destinados a financiar as Ações Básicas de Vigiláncia Sanitária.

A entrada do município na gestão plena do sistema municipal inaugurou nova etapa no processo de municipalização. Algumas das pessoas entrevistadas, quando indagadas a respeito de sua percepção sobre a municipalização da saúde em Marilia, referem-se à mesma como tendo tido inicio nesse periodo, em virtude da visibilidade que teve essa mudança de gestão, especialmente para os prestadores de serviço. Ou seja, para diversos atores locais a municipalização ocorreu em $1^{\circ}$ de junho de 1998.

\subsubsection{A incorporação de novos atores ao sistema de decisões}

Durante esse periodo, com a ampliação da autonomia de gestāo, ampliou-se também o número de atores que passaram a influenciar o processo decisório das politicas locais de saúde. Até esse momento, como vimos no relato referente aos periodos anteriores, tinham maior visibilidade 
no sistema de decisões os governantes locais, os aliados do movimento sanitário, o Conselho Municipal e os Conselhos Locais de Saúde. A partir da habilitação à gestão plena do sistema municipal fica mais evidente a participação dos prestadores de serviço das áreas pública e privada nas arenas politicas locais. Seus interesses têrn, obrigatoriamente, que ser representados nas instâncias locais e não mais no âmbito dos governos estadual e federal. Esses vários atores que interagem nos componentes do sistema de decisões - governantes locais, aliados do movimento sanitário, CMS, CLS e prestadores de serviços - serão analisados a seguir.

\section{OS GOVERNANTES LOCAIS DA SAÚDE}

O secretário e seus principais assessores têm forte identificação com a Reforma Sanitária, como já mencionamos. Sempre fizeram parte do grupo de "aliados do movimento sanitário". Agora, no poder, têm o desafio de colocar em prática um projeto mais consistente de gestão da saúde.

Esse projeto, segundo eles, tinha dois grandes eixos de ação: um voltado para as mudanças na relação com os prestadores de serviço das áreas especializada e hospitalar e outro direcionado à Secretaria de Saúde, visando reorganizar a atenção básica, como mostra o registro abaixo:

Um (dos eixos de ação) é o relacionamento com os prestadores. Refazer todos os convênios (...) viabilizar os níveis secundários e terciário para a atenção primária. Realmente fechar o sistema. Fazer referência e contrareferência, com regras colocadas por nós. Isso é um ponto concreto. Por causa disso, um projeto muito importante é a "Central de Agendamento". Não entra nenhuma cirurgia eletiva de nenhum prestador se não for agendado por nós. Essa é a primeira prioridade.

Uma segunda prioridade do Plano é a questão da Atenção Básica mesmo. É resgatar a atividade programática. Não em detrimento ao pronto atendimento que a gente sabe que é preciso. Por isso a gente está montando dois PAs. Um numa área bem distante. Em cima de dados. De planejamento. Então essa coisa de atenção primária é uma coisa forte. Junto com isso a gente está usando a estratégia do PSF, não como o Ministério está propondo. (Com) cobertura de 100\%. A gente está priorizando áreas periféricas, áreas pobres (procurando fazer com que) pressione a UBS para mudar sua lógica de atendimento. 
Tem o Programa de Internação Domiciliar, que é um proposta forte (do Plano). Agora quando eu falo atividade programática é tudo, não é. Mulher, na área da criança. Em cada uma dessas áreas (o plano) definiu prioridades. Então na criança é o bebê de risco. Na mulher é o Pré-Natal e o Câncer ginecológico (Gestor 6).

Um dos obstáculos para a execução desse projeto, segundo a percepção dos governantes locais, é a organização interna da Secretaria de Saúde. As debilidares da Secretaria para a execução dessa nova missão são bastante destacadas, como mostra esse depoimento:

Então eu acho que tem algumas coisas que não tem jeito. Minha angústia é o fortalecimento técnico da Secretaria. Eu tenho colocado muito isso. E muito complicado. É de dar pena. Tem de pegar na mão. (algumas pessoas) que nào sabem fazer um relatório (...) não sabem trabalhar a informação. (...) você precisa estar mostrando como é que trabalha. (Gestor 6).

Os governantes não parecem ter enfrentado resistências significativas às mudanças propostas. Existe aparente unanimidade à habilitação à gestão plena. Mesmo os aliados do movimento sanitário que não estão participando da administração concordam com os pontos mais importantes:

Acho que no geral (refere-se aos aliados do movimento sanitário) partilham das mesmas idéias. Acho que hoje já não existe uma uniformidade como chegou a existir anos atrás. Essas pessoas partilhavam do mesmo grupo. Tinham a mesma linha. As discussões eram feitas em conjunto. Hoje, já ocorreram algumas rupturas. Mas em termos de ideal de saúde, de um projeto, ainda prevalece o objetivo semelhante. Então eu acho que isto dá uma certa consistência. É claro que cada um tem um projeto diferente. Mas quando vai analisar a questão da municipalização acho que não tem grandes choques. Podem ter visões diferentes mas não tão significativas, que mudem o rumo das coisas (Profissional de saúde 1).

Essa impressão foi reafirmada por outros dados coletados. É preciso ficar claro que os "aliados do movimento sanitário" não constituem um grupo uniforme. Existem projetos distintos no interior desse grupo que geraram, inclusive, disputas politicas acirradas na Faculdade de Medicina. Apesar 
dessa falta de uniformidade na ação politica todos concordam com a proposta de adesão à municipalização da saúde.

Existe também uma imagem de credibilidade dos governantes locais, em especial do Secretário de Saúde, perante a maioria dos outros atores, mesmo entre aqueles que discordam da eficácia da gestão:

O (citando o Secretário) é uma pessoa experiente. (...) Então é uma pessoa que tem uma certa visão. Isso facilitou. Acabou fazendo que a coisa acontecesse. Porque senão estávamos discutindo até hoje. (todo mundo dizendo que a gestão plena) É bom! É bom! E ninguém tomava atitude nenhuma (l - : a rio 1$)$.

Quando se anunciou a municipalização de Marilia, a gestão plena, a primeira sensação que todo mundo teve foi de pânico. Por quê? Porque é sabida a questão da Prefeitura ... utilizar os recursos da maneira que ela bem entende. E a gente não conhecia muito bem a dinâmica. Esse dinheiro: como ele vinha, como ele estava vinculado. Quem estaria usando. Qual era a liberdade do executivo estar metendo a mão nesse dinheiro, ou não. İ ... esse foi o primeiro momento. Num segundo momento, com a indicação do (atual Secretário) como Secretário de Saúde, isto pelo menos trouxe para a gente um cunho de seriedade. $O$ (atual Secretário) não iria se sujeitar a "meter a mão em cumbuca". Então a gente ficou mais tranqüilo (Prestador 1).

O (atual Secretário) é uma pessoa que tem muita experiência na área ... então, ele tem essa visão da coisa. E essa visão aberta dele permitiu que nós construíssemos essa parceria (Prestador 2).

Acontece que, desde que Marilia entrou na gestão plena, eu acho, eu não tenho assim muita idéia, diante de outros lugares. Mas em Marilia eu acho que está funcionando bem. Nós temos um prefeito que está dando muito apoio. Nós temos um Secretário que, além de capacitado, muito capacitado, é uma pessoa excelente (Prestador 3).

Em primeiro lugar é necessário registrar que o nosso Secretário de Saúde é um profissional muito atento às questões de saúde aqui da nossa cidade (Jornalista 1).

A valorização de algumas das caracteristicas pessoais de um dos principais atores na condução da gestão municipal, entre as quais foram ressaltadas a visão e a competência técnica, tiveram influência na interação 
entre os atores. Os governantes locais eram percebidos pela maioria dos atores relevantes como tendo liderança adequada e projeto coerente de mudanças:

(A Secretaria) passou a ter um comando. Uma secretaria que tinha um projeto. (em outros momentos) o Conselho (CMS) (existia) para cumprir a lei. $E$ os conselhos locais de saúde eram uma coisa do UNI. Precisava juntar essas coisas. Não tem cabimento. Aí o (Secretário) vai juntando essas coisas. Ele tem a visão do todo, do projeto (Prestador 4).

Entre os opositores ao grupo político que estava no poder, apesar de não terem sido ressaltadas ou explicitadas essas qualidades, elas não foram negadas. Não foram identificados opositores declarados ao projeto dos governantes locais. As reações contrárias referiam-se a acusações de um certo marketing exagerado utilizado pelos governantes locais. Outros se referiam a centralização na condução do processo, atribuindo caracteristicas de "centralizador" ao seu responsável:

Eu acho que se o Secretário de Saúde tivesse essa linha aberta ... da descentralização ... acho que aí a coisa poderia até funcionar. Mas a gente sabe que ele é centralizador. Ele até fala né ... ele até acredita nisso ... só que o discurso dele é um e a prática é outra ... Então é difícil ... Nós fizemos duas plenárias de saúde. Para estar ouvindo a população. Para estar ajudando nesse processo de municipalização. Estar preparando as pessoas para participarem. E o que ele fez? Ele achou que a gente estava fazendo as plenárias para falar mal do prefeito. Eles devem satisfação para esse povo ... Fica tudo muito difícil. A gente fica muito desesperançoso viu (Usuário 1).

Em sintese, podemos considerar que o projeto proposto pelos governantes locais não encontrou resistências políticas articuladas por parte dos outros atores locais com os quais interagia. Os obstáculos que os governantes locais encontraram para a implementação mais efetiva do seu projeto de governo serão analisados mais à frente. 


\section{OS PRESTADORES DE SERVIÇO}

Com a entrada em vigor da gestão plena municipal de saúde, os prestadores de serviço do SUS, públicos e privados, passaram a negociar seus interesses mais freqüentemente com os governantes locais da saúde. A imagem favorável que tinham dos que conduziam a Secretária de Saúde, conforme acabamos de analisar no tópico anterior, facilitou a pactuação de interesses e o estabelecimento de parcerias. As medidas de regulação e de readequação do papel dos prestadores tomadas pelo gestor não geraram resistências ou discordâncias significativas dos prestadores. As exceções foram a municipalização de gestão financeira dos serviços do Hospital das Clínicas de Marilia e a centralização do atendimento hospitalar de urgência/emergência, de que trataremos adiante.

Entre as diversas parcerias firmadas entre o gestor e prestadores de serviço sobressairam os convênios para a operacionalização de programas como a Saúde da Familia e a Internação Domiciliar. A nova forma de gestão aparentemente contribuiu para desencadear mudanças no interior de algumas organizações hospitalares. Um exemplo foi o da Santa Casa, conforme manifestação de um de seus principais dirigentes:

(Com a ) gestão plena ... nós conseguimos retomar um relacionamento que não era muito bom com a saúde pública e conseguimos resgatar esse processo de transparência na administração. Então, para nós, a negociação com o sistema público local ficou muito mais fácil de ser feita, porque ficou muito mais próximo da realidade do hospital. É muito mais fácil mostrar o hospital hoje ao gestor municipal, do que quando era o estado (governo do Estado) o gestor. Era muito mais difícil esse processo porque ele acabava centralizado de uma certa forma em São Paulo. A descentralização no município facilitou muito. Por que? Porque nós estamos muito mais presente, mostrando a nossa realidade. $E$ isso pra nós foi extremamente positivo, essa reaproximação com o sistema público. Nós tínhamos perdido um pouco a confiabilidade no sistema público. E eu acho que conseguimos resgatar isso. Nós somos um parceiro extremamente importante mas não tínhamos a confiança do poder público. E também, internamente, não tínhamos muito claro aquilo que nós queríamos. Então, a partir do momento que verificamos que temos uma vocação pública. Apesar de sermos um hospital privado nós 
temos uma função pública relevante porque a filantropia no sentido clássico não existe mais. Agora todo cidadão tem direito ao atendimunto. E o Estado paga por esse atendimento. Então aquela filantropia no sentido clássico ela praticamente não existe no setor de saúde. Então, o papel da Santa Casa é um papel que tem que ser um papel ligado ao sistema publico. Só se justifica hoje nesse sentido ... até porque (a Santa Casa) é sem fins lucrativos. Mas tínhamos um relacionamento com o poder público, horrível. Principalmente o governo estadual, que era o gestor ... e fizemos uma política de reaproximação que ficou extremamente positiva. E com a municipalização ficou mais fácil (Prestador 2).

A percepçāo desse e de outros dirigentes dessa instituição de que teriam de readequar-se aos novos tempos, redefinir a sua missão e promover processos de mudança interna ficou bem evidente nas informações obtıdas

Quando a municipalização foi instituída e na prática os recursos passaram a vir pela Secretaria de Saúde (...) a gente pôde sentir que seria um processo interessante. Interessante em que sentido: primeiro, na proximidade com o gestor. É muito melhor você estar conversando com quem vocé conhece. Não no sentido de clientelismo, mas de conhecer profissionalmente. E de estar trabalhando com alguém que também conhece a realidade do município e sabe da importância do hospital no contexto do atendimento loco-regional. A partir daí, a Santa Casa, que tinha um relacionamento muito ruim com o SUS ... mesmo em relação a DIR, era um relacionamento distante. Era um relacionamento onde o hospital cobrava do SUS recursos e o SUS cobrava do hospital a questão do atendimento, a questão de cobrança de diferença (refere-se a "cobranças por fora" para realizar o serviço). Ou seja, a questão do nãocomprometimento do hospital com a questão SUS.

A visão (que se tinha era) de que o grande vilão do déficit do hospital, da crise econômica do hospital era o SUS. E aí (o Hospital) começou a restringir drasticamente $o$ atendimento. $E$, nesse momento, o relacionamento que já não era bom, deteriorou. E aí, a partir de 98 , o hospital entrou numa política de reconstrução de credibilidade através de uma melhora no relacionamento, procurando tentar entender as necessidades do gestor, e ao mesmo tempo fazer o gestor entender as necessidades do hospital. Isso caminhou por uma série de ações das duas partes. Termo aditivo de urgência/emergência. Termo aditivo da unidade de queimados. $\dot{E}$ um dos poucos da região que tem uma unidade desse tipo. Houve um reatamento de relações no sentido de construir um atendimento da população voltado para os interesses dela, através do interesse do gestor. $O$ gestor definia o que ele tinha de gargalo, demanda reprimida de hospital, tentando logicamente atender essas reivindicações (Prestador 1). 
A identificação de propósitos entre os dirigentes, ou ao menos parte deles, e os gestores com os objetivos do SUS não provocou, obviamente, mudança radical no papel tradicionalmente desempenhado por essas instituições. Dificuldades e obstáculos no âmbito interno dessas organizações ficaram mais visiveis para seus dirigentes. Boa parte dos obstáculos estão relacionados com a autonomia do trabalho do médico e com as dificuldades de conciliação dos distintos interesses que coexistem no Hospital.

Aí (com as tentativas de mudança no papel do Hospital) começaram os nossos problemas internos. Porque, essa questão da autonomia do trabalho médico, na Santa Casa era, e ainda ć, maior até do que nos outros hospitais. Porque houve um total deslocamento do trabalho médico da missão institucional. Todo mundo faz aquilo que é de interesse pessoal em detrimento do interesse institucional. Então hoje essa é a maior dificuldade que a gente enfrenta que é de cooptar o corpo clínico para desenvolver um projeto que seria de estar atendendo em função da necessidade e não em função de tabela de remuneração. Eu acho que isso aí é um problema que compromete toda gestão hospitalar privada e filantrópica neste país (Prestador 1 ).

Esses dirigentes estão procurando enfrentar as dificuldades internas através de processos de gestão e planejamento que representam inovações às gestões tradicionais anteriormente desenvolvidas nesses hospitais. Foge dos propósitos deste estudo analisar mais detalhadamente essas dificuldades, sendo suficiente para os nossos objetivos constatar que a municipalização da saúde constituiu fator de estímulo para as mudanças organizacionais. Isso torna-se mais evidente quando os dirigentes hospitalares se colocam como atores politicos aliados dos propósitos do SUS, como pode ser observado, pela manifestação do dirigente, transcrita a seguir:

Eu acho que a municipalização trouxe para o hospital uma série de vantagens. Não só essa questão da proximidade, mas (especialmente) das negociações caminharem e "rolarem" de uma maneira muito mais rápida. $O$ gestor (pode) atender as necessidades agudas do hospital. De repente você tem um problema de folha de pagamento no início do mês e a gente 
consegue adiantamento da Prefeitura ... não adiantamento pra frente mas de serviço já prestado, para poder manter o hospital rodando (Prestador 1).

Em sintese, a percepção dos dirigentes entrevistados foi nitidamente favorável ao processo de municipalização. Isso constituiu fator positivo para avançar na reorganização do sistema de saúde. Depreende-se, das manifestações colhidas, porém, que persistem obstáculos organizacionais nas instituições hospitalares. De acordo com a opinião dos entrevistados, a municipalização da saúde cria condição mais favorável para a superação desses obstáculos. Entendem, no entanto, que persıstem problemas dificeis, especialmente aqueles ligados à incorporação do corpo clínico à lógica do SUS e à alteração de aspectos da cultura da organızação hospitalar, que resistem à mudanças, por estarem ligados a rotinas e valores já consolidados.

Uma das medidas tomadas pelos governantes locais gerou controvérsias: a municipalização da gestão dos recursos do SUS dos hospitais - HC1 e HC2 - da Fundação de Ensino Superior de Marilia, em julho de 1999. É necessário ressaltar que a gestão dos recursos oriundos da prestação de serviços ao SUS realizada pelos hospitais universitários localizados em municipios em gestão plena tem ficado no teto financeiro do governo estadual. Isso não ocorre em todos os estados, mas tem sido uma regra para o Estado de São Paulo. Marilia quebrou essa regra. Os governantes locais, em Marilia, assumiram a gestāo desses dois Hospitais, ampliando com isso o espaço de atuação do poder local.

Essa mudança teve a resistência explícita do governo estadual e no embate entre os dois niveis de governo o secretário de saúde local foi vitorioso ao articular alianças nos fóruns decisórios estaduais, como a Comissão Intergestores Bipartite (CIB) e o Conselho Estadual de Saúde (CES). 
As manifestações de discordância de alguns atores locais a respeito dessa medida são por eles justificadas de três formas diferentes. Uma delas, ao considerar que o controle dos recursos do $\mathrm{HC}$ pelo município poderia reduzir sua abrangência regional. Isso limitava o acesso de pacientes externos. Gestores municipais, no futuro, poderiam "fechar as portas" do municipio aos pacientes de fora para reduzir custos. Isso prejudicaria o municipio, pois toda a estrutura hoje existente - capacidade instalada e recursos humanos capacitados - resultou do papel de referencia regional historicamente desempenhado por esses serviços:

A única, (ressalva que eu faço a respeito da municipalização) é uma questão muito particular, que é o que aconteceu com o Hospital de Clínicas, que pertence à Fundação de Ensino Superior de Marília. A idéia era que você mantivesse esse hospital de uma forma regional. Que ele estivesse ligado à Secretaria Estadual da Saúde e não à questão municipal. Até pelas questões regionais, que ele responde. $O$ que a gente sabe é que as negociaçōes município a município, pra você viabilizar um sistema hierárquico ela é bastante complicada, ainda mais quando envolve as questões financeiras. E todas essas coisas precisam ter uma negociação que não agiliza o processo onde o grande prejudicado acaba sendo o paciente que precisa de um atendimento mais sofisticado. Então, na minha visão, a idéia que eu tinha é que esses hospitais de referência, como é o caso do hospital-escola, deveria ficar no âmbito regional, e não ficaria nessa questão de disputa das verbas da municipalização. (Profissional de saúde 1).

(...) a cidade acaba perdendo muito. O corpo médico foi estruturado para uma questão Regional. E essa regionalização partiu dos hospitais da Fundação. (...) A cidade toda teve (uma) ampliação de seu corpo médico. (Ocorreu) contratação de docentes, qualificação de docentes. Então ... (esta situação) foi avançando e hoje você tem quase 900 médicos para uma população de 180.000 - 190.000 habitantes. A hora que os hospitais da Fundação perdem essa característica regional toda a cidade perde. Agora isto não está sendo sentido mas, ao longo dos próximos anos, Marilia vai ter que repensar toda essa estrutura médica que ela tem. Por que eu acho até que (esta estrutura) está superestimada, agora que ela está só com a questão do município (Profissional de saúde 1).

Existia a preocupação de que a gestão dos recursos do $\mathrm{HC}$ alterasse a atual estrutura de atendimento em virtude de redução da demanda regional histórica. isso tornaria ociosa a capacidade instalada e ocasionaria 
no futuro, fatalmente, segundo esse último entrevistado, modificarões prejudiciais a alguns interesses locais. Entre esses, os dos médicos, do ensino médico e dos serviços especializados de diagnose-terapia e atenção ambulatorial e hospitalar. Isso se daria, basicamente, por meio da redução da influência regional desempenhada pelo municipio, trazendo, conseqüentemente, reflexos no mercado de trabalho e de ensino.

Outra manifestação dessa discordância refere-se ao fato de que essa medida concentra poder nas mãos de um grupo político, podendo vir a ser utilizada como instrumento de manobra politica no futuro

(referindo-se ao HC) sempre teve um vinculo muito forte com o PMDB de Marilia. A Prefeitura e a Secretaria Municipal estão nas mãos do PMDB. Eu vejo que essa disputa por espaços políticos pode vir a prejudicar, ou ao menos não deixar avançar aquilo que poderia avançar. Tem a questào do poder. De você deter o poder financeiro, na ordem de 10, 12 milhỏes de dólares/ano. Deter o número de empregos, que até se equipara à questảo de número de empregos da própria prefeitura, se não passar até dos numeros da prefeitura ... (Profissional de saúde 1).

E, finalmente, uma terceira percepção dos que discordavam da munipalização do controle do HC é o possivel prejuizo financeiro que ele poderia trazer aos outros hospitais que prestam serviços ao SUS no município, como a Santa Casa, a Maternidade Gota de Leite e o Hospital São Francisco:

Até que ponto é interessante um hospital ligado à Faculdade de Medicina, que tinha um caráter regional, ser municipalizado? Tudo bem, pode até ser que ele continue a ter caráter regional. Agora, para continuar a ter esse caráter regional é fundamental uma câmara de compensação. Isso não existe. A minha grande preocupação é a seguinte: Como é que o gestor vai fazer para manter esse hospital funcionando, com uma demanda que não conhece, que não controla. O medo da gente é que o recurso acabe mudando um pouco de caminho. A gente perca teto aqui em função de um hospital que tinha tudo para continuar sendo do Estado. Porque a folha de pagamento continua sendo coberta pelo Estado. É uma Autarquia Estadual. Tem lá recursos de custeio que chegam para ele. Enfim, acho que ele deveria estar funcionando numa outra lógica. Houve um empenho muito grande do (cita o atual secretário de saúde local) para conseguir essa municipalização. 
Se você me perguntar se é favor ou contra eu não saberia responder Mas eu te pergunto o seguinte: essa municipalização está equacionada? $O$ que vai acontecer nesse cenário municipal com a entrada desse gigante que é o hospital escola. Esse complexo hospitalar. São dois grandes hospitais. O que vai acontecer com os outros que são o Hospital São Francisco, a Gota de Leite, que é a Maternidade, e a Santa Casa (Prestador 1).

Outra coisa que a gente tem temor é que esse dois Hospitais, de Clínicas e Municipal, vão entrar numa disputa de verbas da Santa Casa, da Gota de Leite, do Hospital São Francisco. E logicamente por ser um Hospital Público ele teria preferência na disputa dessas verbas. Esses senões, não significando que seja contra a filosofia da municipalização, é que podem tumultuar a plenitude do processo (Profissional de saúde 1).

A explicitação dessa divergência è importante para a presente investigação porque se trata da manifestação de um dos poucos conflitos bem visiveis que tiveram como centro a arena local, em decorrência do processo de municipalização. A mudança do controle dos recursos/SUS do governo do estado para o governo municipal, de aproximadamente um milhão de reais por mês, que é o equivalente à receita/SUS do Hospital das Clínicas, ocasionou preocupação para algumas pessoas e instituições que imaginaram que seus interesses poderiam ser contrariados no futuro.

\subsubsection{O Conselho Municipal de Saúde em uma condição de maior autonomia de gestão}

Nesse período, caracterizado por maior autonomia de gestão, teria aumentado a influência do CMS no sistema de decisão das políticas locais?

Para procurar resposta a essa pergunta, fizemos uma análise dos assuntos discutidos pelo Conselho nesse periodo, comparando com os períodos precedentes. O CMS realizou 39 reuniões de 1997 a 1999 (33 ordinárias e 6 extraordinárias), nas quais surgiram 204 assuntos. Houve predomínio dos assuntos gerenciais e assistenciais, com 39,7\%, seguindose os relacionados à ampliação ou ao aperfeiçoamento do controle social, 
com $27 \%$, e as reclamações sobre a qualidade da assistência ou sobre a remuneração dos serviços prestados pelo SUS, 21,1\% (Tabela 21).

Tabela 21 - Assuntos que entraram na agenda do Conselho Municipal de Saúde, no período de1997 a 1999 - Marília-SP.

\begin{tabular}{lll}
\hline Assuntos & $\mathrm{N}^{\circ}$ & $\%$ \\
\hline Regimentais & 7 & 3,4 \\
$\begin{array}{l}\text { Assuntos gerenciais e assistenciais } \\
\text { Relacionados a campanhas e programas de saúde nacionais }\end{array}$ & 81 & 39,7 \\
$\begin{array}{l}\text { estaduais } \\
\text { Reclamações sobre qualidade da assistência ou sobre remuneração }\end{array}$ & 18 & 8,8 \\
$\begin{array}{l}\text { dos serviços prestados para o SUS } \\
\text { Relacionados à ampliação ou ao aperfeiçoamento do controle social }\end{array}$ & 21,1 \\
\hline Total & 204 & 27,0 \\
\hline
\end{tabular}

Fonte: atas do CMS.

A comparação entre os três periodos, como se pode verificar na Figura 12, mostra que se mantém o padrão de freqüência dos assuntos, a não ser para as reclamações, que foi maior no primeiro período, caiu bastante no segundo e voltou a crescer no último. É necessário ressaltar que a figura mostra as freqüências relativas dos assuntos em porcentagem. Em números absolutos, o último periodo apresentou valores bem maiores que os dos anos precedentes, tendo sido registrado, em média, cerca de 68 assuntos por ano, enquanto nos outros anos (referentes aos períodos de 1989 a 1992 e 1993 a 1996) registraram-se 53 e 27, respectivamente. 


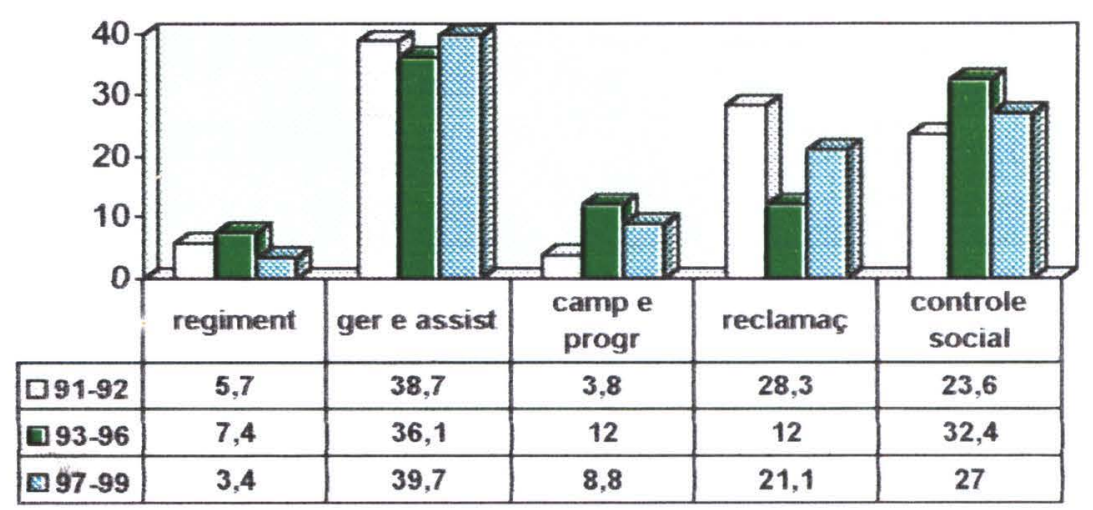

Figura 12 - Comparação entre as freqüências dos assuntos que surgiram nas reuniões do Conselho Municipal de Saúde, nos períodos de 1991 a 1992, 1993 a 1996 e 1997 a 1999 - Marília$\mathrm{SP}(\mathrm{em} \%)$.

A seguir, são analisados os grupos de assuntos mais freqüentes.

\section{ASSUNTOS GERENCIAIS E ASSISTENCIAIS}

As Tabelas 22 e 23 mostram que os informes corresponderam a cerca da metade (ou mais precisamente 50,6\%) dos assuntos relativos a este grupo e foram trazidos principalmente pelos governos federal e estadual $(52,1 \%)$, governantes locais $(33,3 \%)$ e outros - projeto UNI e HC - $(8,3 \%)$.

Tabela 22 - Distribuição dos assuntos gerenciais e assistenciais que surgiram nas reuniões do Conselho Municipal de Saúde, no periodo de 1997 a 1999 - Marília-SP.

\begin{tabular}{lcc}
\hline Assuntos & $N^{\circ}$ & $\%$ \\
\hline Informes & 41 & 50,6 \\
Ligados a mudanças de infra-estrutura - física e de recursos & & \\
humanos - e capacidade instalada da rede de serviços & 17 & 21,0 \\
Ligados a mudanças do modelo assistencial - projetos inovadores e & 23 & 28,4 \\
estudos de clientela. & 81 & 100,0 \\
\hline Total & & \\
\hline
\end{tabular}

Fonte: atas do CMS 
Tabela 23 - Fatores que tornaram relevantes os informes referentes a assintos gerenciais e assistenciais discutidos no Conselho Municipal de Saúde, no período de 1997 a 1999, em Marília-SP.

\begin{tabular}{lll}
\hline Fatores & $\mathrm{N}^{\circ}$ & $\%$ \\
\hline Governos federal e estadual & 25 & 52,1 \\
Governantes locais & 16 & 33,3 \\
Usuários & - & - \\
Prestadores de serviço & 1 & 2,1 \\
Profissionais de saúde & - & - \\
Crise ou eventos dramáticos & 2 & 4,2 \\
Outros & 4 & 8,3 \\
\hline Total* & $48^{*}$ & 100,0 \\
\hline
\end{tabular}

* o número total de informes não é necessariamente igual ao número de fatores que os tornaram relevantes porque mais de um fator pode interagir simultaneamente.

Os ligados a mudanças de infra-estrutura e do modelo assistencial constituiram-se, em sua maioria, de propostas dos governantes locais (90\%), tendo sido implementados em $75 \%$ dos casos (Tabelas 24 e 25 ).

Tabela 24 - Fatores que tornaram relevantes os assuntos ligados a mudanças de infra-estrutura e do modelo assistencial discutidos no Conselho Municipal de Saúde, no periodo de 1997 a 1999, em Marília-SP.

\begin{tabular}{lll}
\hline Fatores & $\mathrm{N}^{\circ}$ & $\%$ \\
\hline Governos federal e estadual & 4 & 10 \\
Governantes locais & 36 & 90 \\
Usuários & - & - \\
Prestadores de serviço & - & - \\
Profissionais de saúde & - & - \\
Crise ou eventos dramáticos & - & - \\
Outros & - & - \\
\hline Total & 40 & 100.0 \\
\hline
\end{tabular}

Tabela 25 - Destino dado aos assuntos ligados a mudanças de infra-estrutura e do modelo assistencial que entraram na agenda do Conselho Municipal de Saúde, no período de 1997 a 1999 - Marília-SP.

\begin{tabular}{lll}
\hline Destino & $\mathrm{N}^{\circ}$ & $\%$ \\
\hline Descartado & - & - \\
Permanecem na agenda & 10 & 25,0 \\
Priorizados & 30 & 75,0 \\
\hline Total & 40 & 100,0 \\
\hline
\end{tabular}

As Figuras 13 e 14 comparam os três periodos. Nota-se que os governantes locais trouxeram mais freqüentemente esses assuntos às 
reuniões do CMS em 97-99 do que nos períodos anteriores. Isso sugere uma atitude mais propositiva do governo local durante esse periodo. Verifica-se também que os governantes locais não só trouxeram proporcionalmente mais assuntos como aumentou, também, o porcentual de sua implementação.

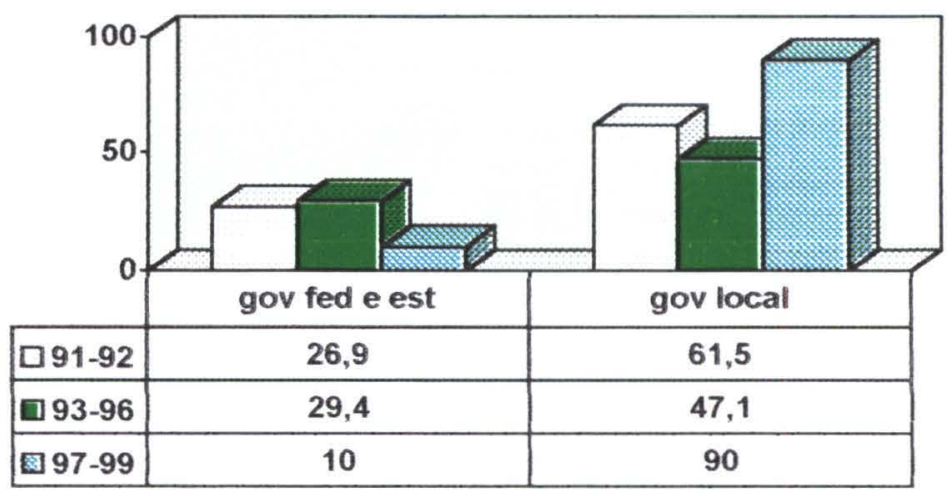

Figura 13 - Comparação entre as frequêencias com que os governos federal/estadual e o governo local trouxeram assuntos gerenciais e assistenciais relacionados a mudanças de infra-estrutura e do modelo assistencial às reuniões do Conselho Municipal de Saúde, períodos de 1991 a 1992, 1993 a 1996 e 1997 a 1999 - Marília-SP (em \%).

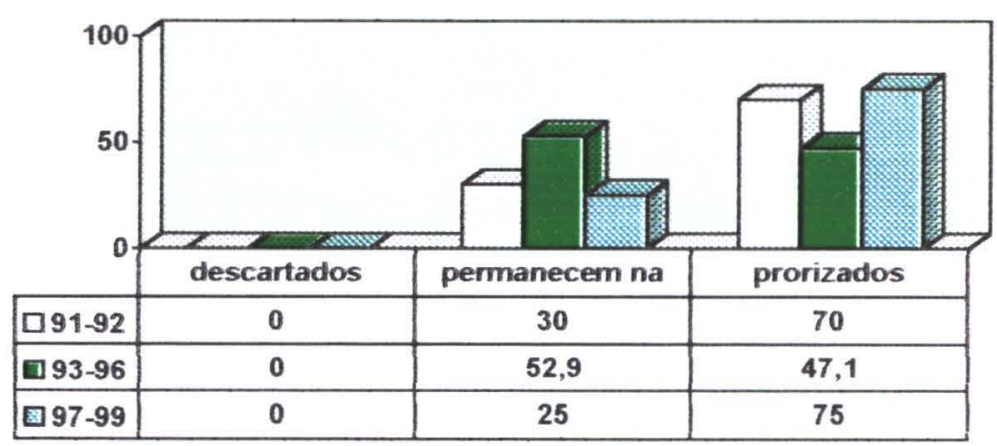

Figura 14 - Comparação entre as frequências dos destinos dados aos assuntos gerenciais e assistenciais relacionados a mudanças de infraestrutura e do modelo assistencial que surgiram nas reuniões do Conselho Municipal de Saúde, nos períodos de 1991 a 1992, 1993 a 1996 e 1997 a 1999 - Marilia-SP (em \%) 
A capacidade de implementação dos assuntos aumentou ano a ano, como mostra a Figura 15. Lembramos que o município entrou em gestão plena do sistema municipal em junho de 1998. Esses achados mostram a ampliação da capacidade de intervenção dos governantes locais com a sua habilitação à gestão plena do sistema municipal e, portanto, reafirmam a expectativa que existe em torno dessa forma de gestão.

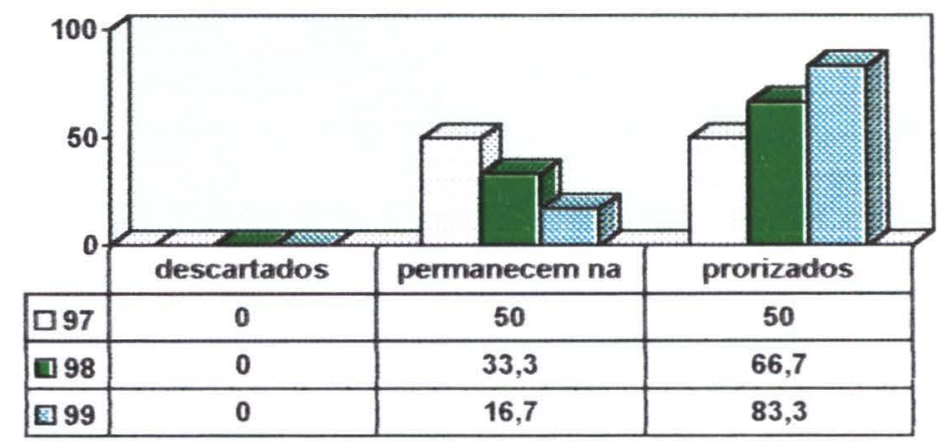

Figura 15 - Comparação entre as freqüências dos destinos dados aos assuntos gerenciais e assistenciais relacionados a mudanças de infraestrutura e do modelo assistencial que surgiram nas reuniões do Conselho Municipal de Saúde, períodos de 1991 a 1992, 1993 a 1996 e 1997 a 1999 - Marília-SP (em \%).

A ampliação da capacidade de implementação das propostas apresentadas pelos governantes locais no último ano desse período fica mais clara quando analisamos o tipo de assunto tratado. Alguns exemplos: (1) implantação do PSF; (2) convênio com prestadores para implantar alguns programas inovadores; (3) implantação do pronto-atendimento em convênio com hospital do município; (4) realização de estudos epidemiológicos; (5) implantação da internação domiciliar etc.

Nota-se que os governantes locais do último período ficaram mais pró-ativos, mais formuladores. Passam a ocupar a agenda em uma situação de maior governança. Enquanto em períodos anteriores discutiam-se predominantemente as "intenções" de mudanças nos modelos gerencial e 
assistencial, neste periodo, além das "intenções", que também estão presentes, passaram a discutir-se "açōes". Passa a ocorrer com mais freqüência "o diálogo entre as intenções e as ações", como afirma HOPPE e col. (apud USP ${ }^{125}, 1988$ ) ao definir o processo decisório; ou seja, passa a haver, mais freqüentemente, decisão no âmbito do poder local.

\section{ASSUNTOS RELACIONADOS À AMPLIAÇÃO OU APERFEIÇOAMENTO DO CONTROLE SOCIAL}

Esse grupo de assuntos tornou-se relevante por influência dos governantes locais $(52,7 \%)$ e governos federal/estadual $(36,5 \%)$ (Tabela 26 ). Nenhum dos temas relacionados à ampliação e ao aperfeiçoamento do controle social foi descartado, tendo sido priorizados por expressiva maioria $(89,1 \%)$ (Tabela 27$)$.

Tabela 26 - Fatores que tornaram relevantes os assuntos relacionados à ampliação ou ao aperfeiçoamento do controle social discutidos no Conselho Municipal de Saúde, no período de 1997 a 1999, em Marilia-SP

\begin{tabular}{lll}
\hline Fatores & $\mathrm{N}^{\circ}$ & $\%$ \\
\hline Governos federal e estadual & 27 & 36,5 \\
Governantes locais & 39 & 52,7 \\
Usuários & 3 & 4,0 \\
Prestadores de serviço & - & - \\
Profissionais de saúde & - & - \\
Crise ou eventos dramáticos & - & - \\
Outros & 5 & 6,8 \\
\hline Total & 74 & 100,0 \\
\hline
\end{tabular}

Tabela 27 - Destino dado aos assuntos relacionados à ampliação ou ao aperfeiçoamento do controle social que entraram na agenda do Conselho Municipal de Saúde, no período de 1997 a 1999 - Marília-SP.

\begin{tabular}{lll}
\hline Destino & $\mathrm{N}^{\circ}$ & $\%$ \\
\hline Descartado & - & - \\
Permanecem na agenda & 6 & 10,9 \\
Priorizados & 49 & 89,1 \\
\hline Total & 55 & 100,0 \\
\hline
\end{tabular}

Comparando os três períodos, como mostra a Figura 16, verifica-se que o comportamento foi semelhante. A implementação dos mecanismos formais de aperfeiçoamento e ampliação do controle social trazida pelos três 
níveis de governo foi bem sucedida em todos. Ou seja, mesmu em momentos de pouca autonomia de gestão, que foi uma das características dos dois primeiros períodos, foi possivel implementar essas medidas. Essas políticas "regulatórias", como mostram os dados, têm facilidade de se institucionalizar nas arenas locais.

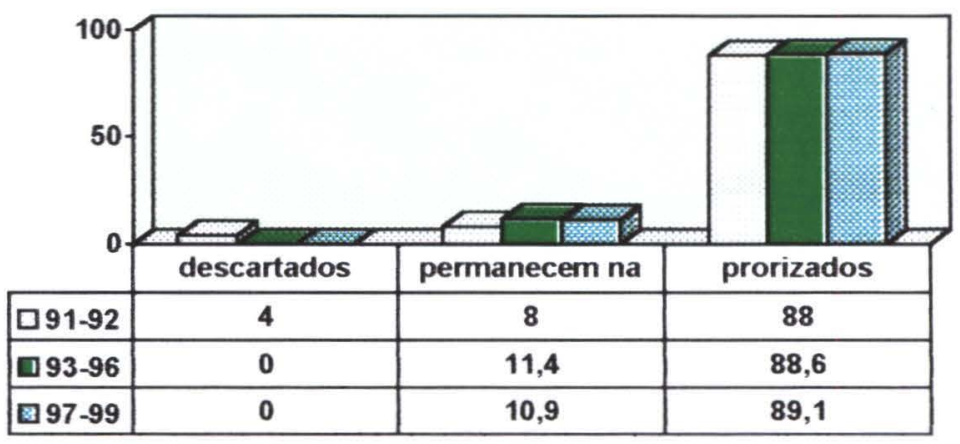

Figura 16 - Comparação entre as freqüências dos destinos dados aos assuntos relacionados à ampliação ou aperfeiçoamento do controle social que surgiram nas reuniões do Conselho Municipal de Saúde nos períodos de 1991 a 1992, 1993 a 1996 e 1997 a 1999 - Marilia-SP (em \%).

As políticas propostas pelos governos federal, estadual ou municipal, cujo propósito é o de ampliar a participação da população no setor saúde, têm sido implementadas. Grande número dessas diz respeito a prestação de contas de recursos do fundo municipal de saúde, formação de conselhos gestores de unidades, realização de conferências etc.

Esses achados mostram, como comentamos acima, que essas propostas podem também ser implementada em situações de pouca autonomia de gestão. Coincidem com os dados dos estudos de TEIXEIRA ${ }^{123}$ (1997) que, em pesquisa sobre municipalização da saúde, identificou a dimensão social, a que se refere à participação social, como a que mais avançou. É importante lembrar que nesse estudo a maioria dos municípios pesquisados estava habilitada em condições de gestão que Ihes conferiam baixa autonomia. A NOB SUS/96 ainda não estava em vigor. Isso confirma 
que os avanços na dimensão social ocorrem independentemente da condição de gestão.

É necessário destacar, no entanto, que a ampliação ou aperfeiçoamento da participação e do controle social se dá em seus aspectos formais, com a consolidação dos instrumentos legais, tais como constituição de conselhos, realização de conferências e fiscalização de contas. Os aspectos mais substantivos de controle social em saúde serão analisados no próximo capitulo.

RECLAMAÇÕES SOBRE A QUALIDADE DA ASSISTÉNCIA OU SOBRE A REMUNERAÇÃO DOS SERVIÇOS PRESTADOS PARA O SUS

As reclamações ou reivindicações originaram-se mais freqüentemente dos usuários $(45,1 \%)$ e dos prestadores de serviço $(31,4 \%$ ) (Tabela 28 ). $O$ destino dado às reclamações foi o descarte para $23,2 \%$ delas. A priorização foi de apenas $18,6 \%$, sendo que $58,1 \%$ tiveram aparente reconhecimento dos presentes, permanecendo como assuntos de agenda, porém não tiveram encaminhamento, mantendo-se como queixas ou reivindicações consideradas sem solução (Tabela 29).

Tabela 28 - Fatores que tornaram relevantes os assuntos relacionados às reclamações sobre qualidade da assistência ou sobre remuneração dos serviços discutidos no Conselho Municipal de Saúde, no periodo de 1997 a 1999, em MaríliaSP.

\begin{tabular}{lll}
\hline Fatores & $\mathrm{N}^{\circ}$ & $\%$ \\
\hline Governos federal e estadual & 1 & 2,0 \\
Governantes locais & 4 & 7,8 \\
Usuários & 23 & 45,1 \\
Prestadores de serviço & 16 & 31,4 \\
Profissionais de saúde & 4 & 7,8 \\
Crise ou eventos dramáticos & - & - \\
Outros & 3 & 5,9 \\
\hline Total & 51 & 100,0 \\
\hline
\end{tabular}


Tabela 29 - Destino dado às reclamações sobre qualidade da assistência ou ssbre remuneração dos serviços que entraram na agenda do Conselho Municipal de Saúde, no período de 1997 a 1999 - Marília-SP.

\begin{tabular}{lll}
\hline Destino & $\mathrm{N}^{\circ}$ & $\%$ \\
\hline Descartado & 10 & 23,2 \\
Permanecem na agenda & 25 & 58,1 \\
Priorizados & 8 & 18,6 \\
\hline Total & 43 & 100,0 \\
\hline
\end{tabular}

A Figura 17 compara a freqüência de reclamações de usuários e prestadores de serviço nos três períodos analisados. Verificou-se maior freqüência na reclamação dos usuários no último, que atingiu 45,1\% do total. Analisando os três anos do último período de forma separada, como mostra a Figura 18, verifica-se que esse aumento foi progressivo, tendo atingido $61,5 \%$ no ano de 1999 .

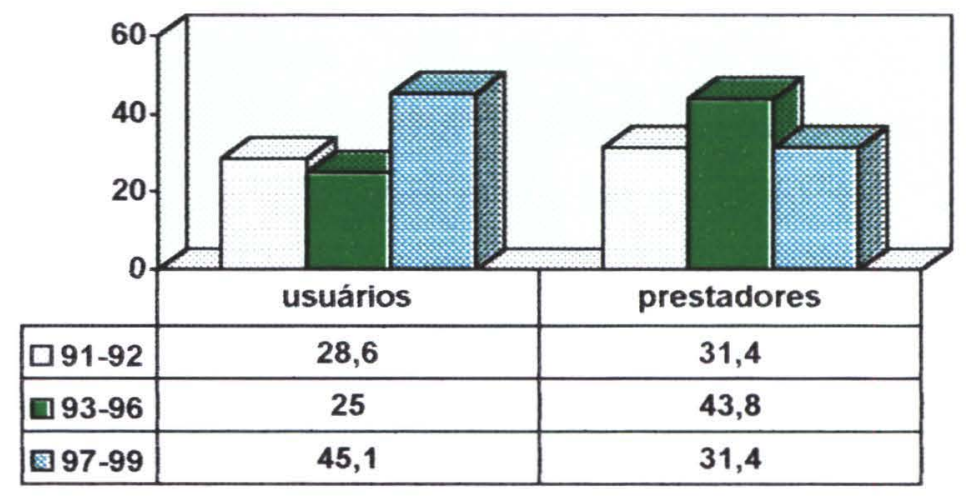

Figura 17 - Comparação entre as freqüências com que os usuários e os prestadores de serviço trouxeram reclamações sobre a qualidade da assistência ou sobre a remuneração dos serviços prestados às reuniões do Conselho Municipal de Saúde, períodos de 1991 a 1992, 1993 a 1996 e 1997 a 1999 - Marília-SP (em \%). 


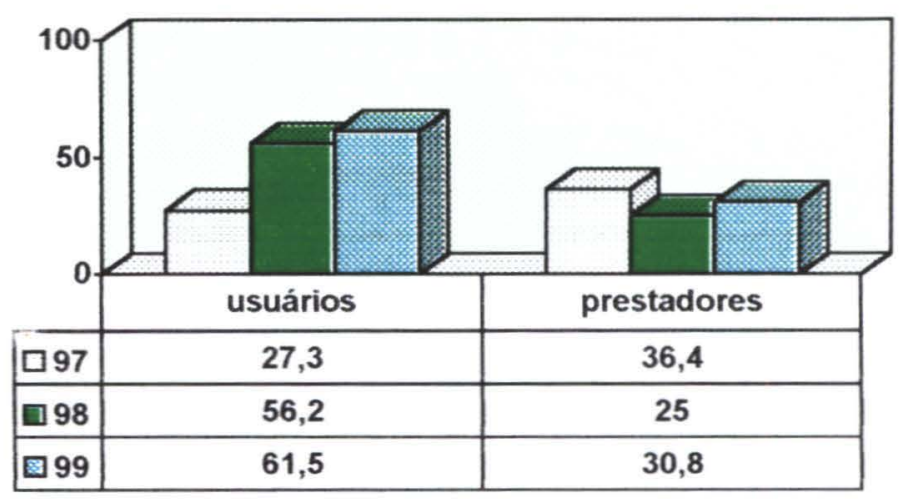

Figura 18 - Comparação entre as frequêencias com que os usuários e os prestadores de serviço trouxeram reclamações sobre a qualidade da assistência ou sobre a remuneração dos serviços prestados nas reuniões do Conselho Municipal de Saúde, nos anos de 1997,1998 e 1999 - Marília-SP (em \%).

É importante registrar que, em números absolutos, conforme mostraram tabelas anteriores, esses assuntos foram maiores no período de 1991 a 1992 (30 assuntos), diminuíram no periodo de 1993 a 1996 (13 assuntos) e voltaram a subir no período de 1997 a 1999 (43 assuntos).

Como mostra a Figura 19, essas queixas foram pouco solucionadas nos três períodos, tendo sido observada pequena tendência de melhora no último. 


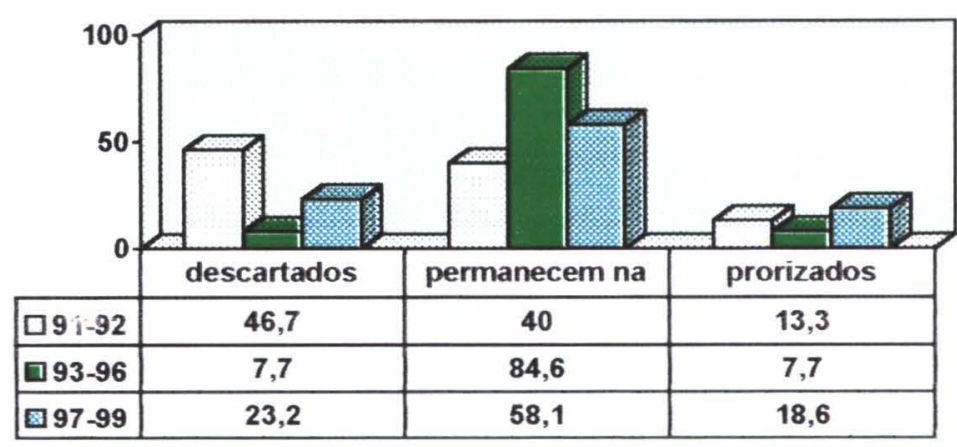

Figura 19 - Comparação entre as freqüências dos destinos dados às reclamações sobre a qualidade da assistência ou sobre a remuneração dos serviços que surgiram nas reuniões do Conselho Municipal de Saúde, nos períodos de 1991 a 1992, 1993 a 1996 e 1997 a 1999 - Marília-SP (em \%).

Mesmo não tendo comportamento muito uniforme, os dados mostraram a pouca capacidade do poder local em solucionar a maioria dessas queixas. É interessante observar que, com a maior autonomia de gestão, as queixas dos usuários tornaram-se mais comuns do que as dos prestadores. Verifica-se também que as reclamações não estão tendo possibilidade de solução, mesmo com a maior autonomia propiciada pela gestão plena do sistema municipal.

Para melhor compreensão dos limites do poder local, é importante diferenciar a natureza das reclamações trazidas por usuários e prestadores às reuniões do CMS. Os assuntos desse grupo trazidos pelos prestadores de serviço são habitualmente os seguintes, entre outros:

1. solicitação de verbas para reforma de hospitais;

2. mudanças na programação de serviços;

3. reivindicação por equipamentos.

Os usuários, por sua vez, traziam habitualmente os seguintes assuntos, entre outros: 
1. hospitais dão preferência a usuários que têm planos de saúde, em detrimento dos pacientes do SUS;

2. sobrecarga no atendimento dos serviços de emergência em decorrência de baixa resolubilidade das UBS;

3. reclamação sobre falta de acesso a determinados serviços especializados;

4. propostas de atendimento noturno nas UBS;

5. falta de recursos de usuários para adquirir medicamentos;

6. denúncia de casos de mal atendimento.

Os assuntos trazidos por usuários e prestadores foram de natureza diversa. Consideramos que os prestadores trouxeram assuntos que, no seu entender, estavam mais próximos da capacidade de intervençăo dos governantes locais em gestão plena. As parcerias conseguiram acolner boa parte dessas reivindicações. Além disso, os prestadores, com a negocıação das parcerias e com a possibilidade de interlocução direta com os governantes locais em gestão plena, perceberam que o CMS nảo é necessariamente o fórum para o processamento dos seus problemas. Os problemas trazidos pelos usuários, por outro lado, eram, em geral, de solução mais complexa.

Essas inferências do último parágrafo permitem delimitar espaços do poder local. A autonomia de gestão aumenta a capacidade de intervenção no modelo de saúde. Essa capacidade, no entanto, permanece insuficiente para processar muitas políticas que são de interesse do usuário.

Com respeito ao número absoluto de assuntos, a comparação entre os três períodos mostrou que o número foi em média de 54/ano para o primeiro, 27/ano para o segundo e 68/ano para o terceiro periodo. O registro das atas nem sempre é fiel ao que ocorre nas reuniões, podendo variar bastante na dependência de quem as redige, que pode valorizar alguns 
assuntos e não outros, não havendo um controle de qualidade sobre os registros. Os números encontrados, portanto, constituem apenas indicativos que contribuem para a análise. Apesar disso, permitem supor que no início, no primeiro periodo, o CMS debatia mais e que houve refreamento da importância dada a esse fórurn no segundo periodo, enquanto no terceiro o debate se ampliou novamente.

Esse comportamento pode estar relacionado com a importância atribuida ao CMS pelos usuários e prestadores? É possivel, já que nesse último período, com ampliação da autonomia de gestão após a habilitação à plena do sistema municipal, o CMS passou a tratar de um maior número de assuntos relativos a reclamações e reivindicações. Comparando o primeiro e o último ano desse período, verificou-se que, no ano de 1997, quando o municipio ainda não estava em gestão plena, surgiram 45 assuntos no CMS. No ano de 1999, já em plena vigência da gestão plena, o número de assuntos abordados quase dobrou, tendo sido registradas nas atas 88 reclamações e reivindicações.

\subsubsection{Conselhos locais de saúde}

Em reunião realizada no dia 30 de abril de 1997 o CMS aprovou alterações no funcionamento e regimento dos CLS. Entre essas, ficou decidido que, na composição desses conselhos, os usuários correspondiam a no mínimo 50\%, podendo ultrapassar esse número. Essa alteração foi ratificada pela alteração do artigo $2^{\circ}$ do Decreto 7292/96, mas, paradoxalmente, essa mudança foi entendida pela Comunidade como sendo um retrocesso, segundo consta em Relatório de Avaliação do Projeto UNIMarilia (Projeto UNI-Marilia99, 1998, p.94).

O Projeto UNI, no início de 1997, que avaliou o funcionamento dos CLS, identificou fragilidades e fortalezas no seu funcionamento. As fragilidades apontadas foram: representatividade e legitimidade dos 
membros, tendências à resolução pontual dos problemas, preconceitos em relação a fazer política e incipiente discussão sobre as causas dos problemas de saúde. As fortalezas apontadas foram: nova inserção da comunidade nos serviços de saúde; maior interação com os serviços de saúde, inserção de representantes dos conselhos locais de saúde no CMS e desenvolvimento das organizações comunitárias através do enfoque intersetorial

Nesse mesmo ano, em novembro, os coordenadores de área da Secretárıa Municipal de Higiene e Saúde e o Núcleo de Apoio à Comunidade do Projeto UNI-Marília - profissionais responsáveis pela gerência e reorganızaçåo dos serviços de área que compreende várias UBS - fizeram uma avaliação do funcionamento dos Conselhos Locais de Saúde. Essa avaliaçāo concluiu que "os conselhos locais de saúde sofrem problemas de articulaçåo, falta comunicação, alguns conselhos são desestimulados por consequéncia da burocracia e das discussões administrativas que ocorrem nas reunibes" (Projeto UNI - Marilia ${ }^{98}, 1997$ ).

No período de 1997 a 1999, foram analisadas as atas das reuniōes dos mesmos CLS pesquisados no periodo anterior (PAS Santa Antonieta; São Judas; Bandeirantes; Altaneira; Vila Coimbra; Aeroporto; Castelo Branco). Como mostra a Tabela 30, esses CLS realizaram 97 reuniōes e trataram de 211 assuntos. A média de participantes, avaliada pelo número de pessoas que assinaram as atas, foi de 8,8, um pouco inferior a de 9,8, encontrada no período anterior. 
Tabela 30 - Número de reuniões e de assuntos discutidos nas reuniões dos Conselhos Locais de Saúde de sete Unidades de Saúde, no período de 1997 a 1999 Marilia-SP.

\begin{tabular}{lll}
\hline Unidade de Saúde & $\mathrm{N}^{\circ}$ de reuniões & $\mathrm{N}^{\circ}$ de assuntos \\
\hline Santa Antonieta & 11 & 22 \\
São Judas & 9 & 12 \\
Bandeirantes & 12 & 24 \\
Altaneira & 17 & 27 \\
Vila Coimbra & 19 & 64 \\
Aeroporto & 17 & 40 \\
Castelo Branco & 12 & 22 \\
\hline Total & 97 & 211
\end{tabular}

Fonte: Atas dos CLS

Os assuntos mais freqüentes (Tabela 31) foram os relacionados à divulgação de informações aos conselheiros/usuários, com 25,6\% do total, seguidos pelas reclamações relacionadas à UBS $(13,7 \%)$ e pelas referentes a estudo de clientela e ligados a mudanças do modelo gerencial e assistencial, reflexões sobre processo saúde/doença e problemas de saúde da área de abrangência, e os relacionados à mobilização da população para solução de problemas do bairro (mutirões), ambos com 12,8\%.

A comparação desse periodo com o anterior, (Tabela 32), permite verificar o seguinte:

(1) As reclamações referentes à estrutura das UBS relacionadas com problemas de demanda reprimida sofreram uma diminuição. Somadas, eqüivaleram a $33,8 \%$ no período anterior e a $21,3 \%$ no último período.

(2) As sugestões dos conselheiros-usuários aos outros membros do conselho aumentaram de $7,5 \%$ para $12,3 \%$. 
Tabela 31 - Distribuição dos assuntos que surgiram nas reuniões dos CLS das UBS Santa Antonieta, São Judas, Bandeirantes, Altaneira, Vila Coimbra, Aeroporto, Castelo Branco, realizadas no período de 1997 a 1999 - Marília-SP.

\begin{tabular}{|c|c|c|}
\hline Tipo de assunto & $\mathrm{N}^{\mathrm{o}}$ & $\%$ \\
\hline Relacionados $\dot{a}$ & & \\
\hline conselheiros/usuários & 54 & 25,6 \\
\hline Reclamações e reivindicações relacionadas às UBS & 29 & 13,7 \\
\hline $\begin{array}{l}\text { Estudo de clientela e ligados a mudanças do modelo gerencial e } \\
\text { assistencial; reflexões cobre processo saúde/doença e problemas }\end{array}$ & & \\
\hline de saúde da área de abrangência & 27 & 12,8 \\
\hline $\begin{array}{l}\text { Relacionados a mobilização da população para solução de } \\
\text { problemas do bairro (mutirões) }\end{array}$ & 27 & 12,8 \\
\hline $\begin{array}{l}\text { Relacionados a sugestões dos conselheiros/usuários aos outros } \\
\text { membros do CLS }\end{array}$ & 26 & 12,3 \\
\hline Regimentais & 21 & 9,9 \\
\hline $\begin{array}{l}\text { Reclamações e reivindicações relacionados à demanda } \\
\text { reprimida na assistência básica e especializada }\end{array}$ & 16 & 7,6 \\
\hline Ligados à desmotivação dos conselheiros à participar & 6 & 2,8 \\
\hline $\begin{array}{l}\text { Justificativa dos gestores (locais ou municipais) às reclamações } \\
\text { dos conselheiros/usuários }\end{array}$ & 5 & 2,4 \\
\hline Total & 211 & 100,0 \\
\hline
\end{tabular}

Tabela 32 - Distribuição dos assuntos que surgiram nas reuniões dos CLS das UBS Santa Antonieta, São Judas, Bandeirantes, Altaneira, Vila Coimbra, Aeroporto, Castelo Branco, realizadas nos períodos de 1993 a 1996 e 1997 a 1999 - Marília-SP.

\begin{tabular}{|c|c|c|c|c|}
\hline \multirow[b]{2}{*}{ Tipo de assunto } & \multicolumn{2}{|c|}{$93-96$} & \multicolumn{2}{|c|}{$97-99$} \\
\hline & $N^{\circ}$ & $\%$ & $\mathrm{~N}^{\circ}$ & $\%$ \\
\hline Relacionados à divulgação de informações aos & & & & \\
\hline conselheiros/usuários & 48 & 22,5 & 54 & 25,6 \\
\hline Reclamações e reivindicações relacionadas às UBS & 47 & 22,1 & 29 & 13,7 \\
\hline $\begin{array}{l}\text { Estudo de clientela e ligados a mudanças do modelo } \\
\text { gerencial e assistencial; reflexões sobre processo } \\
\text { saúde/doença e problemas de saúde da área de }\end{array}$ & & & & \\
\hline abrangência & 32 & 15,0 & 27 & 12,8 \\
\hline Reclamações e reivindicações relacionados à demanda & & & & \\
\hline reprimida na assistência básica e especializada & 25 & 11,7 & 16 & 7,6 \\
\hline $\begin{array}{l}\text { Relacionados a mobilização da população para solução } \\
\text { de problemas do bairro (mutirões) }\end{array}$ & 19 & 8,9 & 27 & 12,8 \\
\hline Relacionados a sugestões dos conselheiros/usuários & & & & \\
\hline aos outros membros do CLS & 16 & 7,5 & 26 & 12,3 \\
\hline Regimentais & 15 & 7 & 21 & 9,9 \\
\hline $\begin{array}{l}\text { Ligados à desmotivação dos conselhelros à participar } \\
\text { Justificativa dos gestores (locais ou municipais) às }\end{array}$ & 7 & 3,3 & 6 & 2,8 \\
\hline reclamações dos conselheiros/usuários & 4 & 1,9 & 5 & 2,4 \\
\hline Total & 213 & 100,0 & 211 & 100,0 \\
\hline
\end{tabular}


É difícil fazer inferências com esses achados. Um fator que prejıdica a análise é a pouca representatividade desse fórum. As diversas áreas de abrangência das UBS têm milhares de potenciais usuários em cada uma e essas reuniões tinham a participação de oito pessoas, em média, a metade das quais, habitualmente, era constituída de funcionários das UBS

Além disso, a falta de autonomia decisória nas UBS e a ausência de mecanismos que assegurassem que as decisões tomadas nos CLS chegassem aos fóruns de decisão, tornaram essas instâncias praticamente destituidas de poder para dar encaminhamento a muitos dos problemas considerados relevantes pelos usuários.

A intenção de envolver a comunidade, integrando-a com as atividades da UBS, está presente no discurso dos atores relevantes. Reconhecem que esse envolvimento praticamente não tem ocorrido, em virtude da pouca participação e do pouco interesse das pessoas da comunidade em participar. A explicação desses atores a respeito das dificuldades encontradas contribuiu para identificar a percepção que elas têm sobre essa estratégia de participação. Percebem-se diferentes ênfases no discurso dos atores:

1. Falta de compromisso das pessoas:

Eu acho que, particularmente aqui, na Unidade, a participação é ruim. Ela seria boa, ... desde que tivessem participantes ativos. Mas não existem. Nós tínhamos Conselhos Locais. Mas acabamos com os Conselhos Locais. Por quê? Nas reuniões, eu acabei indo nas reuniões sozinha. Nas seis últimas reuniões eu fui sozinha. Vieram eu e uma funcionária da unidade. (...) Agora, com a questão da Carta Sanitária, nós estivemos reunidos aqui de novo, pra trabalhar esse planejamento. Para fazer esse Planejamento, nós tivemos que localizar algumas pessoas da comunidade para estar participando. Está bem no começo ainda ... Eu noto, (quanto) a participação das pessoas, elas não querem ter compromisso ... elas não conseguem trabalhar o macro. Se pra elas aquilo não é problema, elas não querem saber. Elas são representantes da comunidade mas não vêem dessa forma. Isto acaba desmotivando. Principalmente os funcionários que participavam. Eu também, enquanto 
presidente do Conselho (me sinto desmotivada)... estamos fazendo as operações para resolver os problemas (método MAAP)... uma possível operação. Estamos na terceira reunião. E a gente fez a terceira reunião e está caminhando. A gente está tentando integrar as pessoas que estão dentro. Mas é difícil (Gestor 9).

\section{A organização das reuniões (horário, linguagem) não favorece a} ampliação da participação:

(...) marcam reunião as 2 horas da tarde. As pessoas não podem ir as duas horas da tarde. Então, enquanto você não começar a se preocupar com isto ... A idéia até que era boa: passar informações sobre a situação do local. As pessoas iam ouvir. E recolher sugestões da comunidade sobre o que fazer. Ouvir os problemas e escolher um. Para aquele (prioritario) a Secretaria assumia o compromisso de resolver. Mas, a maioria das pessoas que participaram da reunião eram aposentados. Até, se resolvessem o problema daquelas pessoas (já seria bom) (...) me parece que o problema delas era a questão de oftalmologia. Dificuldades ... "séculos" para conseguir uma consulta e tal ... Até que seria bom. Resolvia esse. Depois o outro. Achei fantástico. Só que, por falta de prática democrática, você esquece de fazer um levantamento (da disponibilidade das pessoas). O Centro de Saúde ainda funciona em horário comercial. Fecha em horário de almoço. Se você vê que as pessoas só podem fazer reunião sábado as 4 da tarde (...) tem que ir. As pessoas não tem outro horário. Outra coisa, fazer reunião em Igreja Católica. As pessoas que são de outra seita, até por causa desta questão pentecostal, não pisam na igreja católica. Escola é um local ideal para fazer reunião. As pessoas não teriam dificuldades. São pequenos cuidados. A linguagem. O rapaz que foi apresentar os dados usou uma linguagem que nem eu uso. ... "Repasse de recursos" ... "os recursos são repassados fundo a fundo" ... isto é aqui entre nós (técnicos) É grego (para a população). (...) . Nós não temos essa prática democrática (Profissional de saúde 2).

3. As pessoas não participam das reuniões do CLS porque estão preocupadas com coisas que elas sabem que não podem ser resolvidas nos conselhos:

Eu moro numa área que deve ser uma das áreas mais complicadas aqui do município. E uma área que até pouco tempo tinha um índice de mortalidade infantil alto. E, (referindo-se ao Secretário) sempre cobrava muito do pessoal do Conselho. O pessoal do Conselho não faz nada. Eu falei: primeiro eles não vão fazer mesmo, porque eles (desconhecem este dado). Mortalidade infantil. Isso não é passado (informado) para as pessoas. Segundo: eles vão fazer o quê? $O$ que a gente pode fazer? $A$ gente não tem poder de decisão a não ser pressionar as pessoas ... A Secretaria da Saúde deveria então trabalhar mais articulada com as outras secretarias. Porque as pessoas aqui estão desempregadas. É uma área que tem cinco favelas. Ali tem que ter uma política de urbanizar aquelas 
favelas. Ajudar a gente, porque a gente está tentando formar cooperaivas de trabalhadores de catadores de lixo, de papel de papelão, de produtos recicláveis ... Nós estamos fazendo isso na nossa comunidade, na raça. Por que? Porque a Secretaria de Saúde não tem um trabalho articulado com as outras. E se tivessem, talvez fosse até mais fácil eles perceberem a importância disso. Aí sim, você melhora a qualidade de vida do cidadão as pessoas não vão adoecer. Vão adoecer mas vai ser uma coisa (menos freqüente).... Moram numa favela. As pessoas não tem acesso ao esgoto. A favela não é urbanizada. É um pó danado lá no setor porque as favelas não são asfaltadas. $E$ a coisa é tão assim louca que quando você pergunta pras pessoas que moram na favela o que você acha que precisa melhorar, eles pedem o asfalto. Eles não pedem nem casa. E quando a gente pergunta mas por que o asfalto eles falam: Porque assim não vem pó aqui. É super interessante conversar com o pessoal. Então, talvez se investisse nisso. Se tivesse um trabalho com as outras secretarias, mais articulado, melhoraria muito.

Quando a gente pergunta eles pedem asfalto ... eles pedem a casa, a casa pra morar. Pra urbanizar ou montar um núcleo pra eles estarem pagando. Sem esquema de mutirão.

A compreensão deles de saúde é que tenha mais médico, mais posto. Que você acha que tem que fazer para melhorar? Ah! Eu acho que tem que ter mais médico. (mas também) teria que melhorar a qualidade de vida deles ... é uma população bem carente ... (Usuário 1).

4. As pessoas não participam porque vivem o "hoje"; lutam pela sobrevivência:

(...) a pessoa que é muito pobre, que está desempregada ela vive ali o dia a dia. Por exemplo, ela quer comer: ela tem que batalhar. Outro dia eu estava vendo um pessoal que dizia assim: bom, eu tenho que vender este papelão hoje porque eu tenho que comprar arroz, feijão. Eles tem que comer hoje. Eles vivem o hoje. E essa luta do SUS não é pra hoje ... é pra amanhã ... então como que essa pessoa que vive o hoje vai lutar pra melhorar a área da saúde pra amanhã? Ela vive o hoje. Ela não quer nem saber. Então nós estamos tentando mobilizar a classe média pra entrar nessa luta com a gente. Eu espero que no futuro a classe média esteja mobilizada e exija melhoria de fato, de atendimento, de qualidade de vida não só pra eles mas pras pessoas em geral. Essa luta é uma luta nossa (da classe média). (Somos) nós que vamos ser os futuros usuários disso aí. Então a gente tem que abraçar essa causa pra melhorar (Usuário 1).

\section{Não existe interesse de participar porque os Conselhos não têm poder:}

Você tem os CLS, conselhos regionais de saúde, conselho municipal, estadual ... mas ... você não tem poder de decisão. $O$ poder de decisão ainda está centrado no poder político. Isto prejudica a atuação da 
população. A população ainda não entende bem tudo isto. Mas os conselheiros já (entendem).. porque participam. Mas infelizmente, isto tem mudado muito na papel, mas não tem mudado na prática (Usuário 3).

Essas diferentes racionalidades que procuram explicar o motivo da pouca participação da população nos CLS nos ajudam a entender a complexidade dessa questão. Alguns atores do movimento sanitário, diante desse fato, admitem que se encontram diante de um desafio não-superado:

Acho que a questão da participação comunitária é um nó do sistema de saúde. É um desafio que está posto e que a gente não conceguiu, ainda, resolver. Me recordando um pouco do inicio do processo, quando estava no ERSA, ... CRIS, CIMS, ... foi o primeiro momento em que se tentou trabalhar esta questão. O UNI, também, tem ... o componente comunidade, que tentou estimular, tenta estimular, essa participação. $O$ problema é a dificuldade que a população sente. (...) . F, a questão da

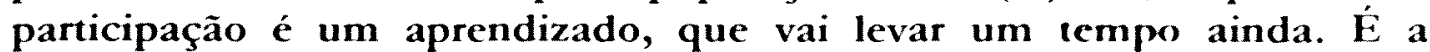
questão da cidadania mesmo. As pessoas se conscientizarem de seus direitos ... é um aprendizado que vai ter que ir devagar mesmo. Avançou. Nós temos o CMS ... Mas eu fico com uma sensação ... t uma questão minha ... fico com uma (preocupação) da questão da representação. Na verdade, na maioria das vezes ele (o representante) representa um segmento, quando não, representa ele próprio. $O$ representante é ele próprio. Não consegue ter uma visão mais ampla. Isso dificulta. Tá certo, a gente faz curso de capacitação e tal ... mas esta e uma questão complicada, na minha visão. Não tenho claro como é que a gente vai desenrolar isto (Gestor 7).

Esses achados, no nosso ponto de vista, reafirmam o que já foi anteriormente comentado a respeito dos limites dos Conselhos Locais de Saúde para o encaminhamento das politicas locais. Quando os assuntos tratados pelos conselhos dizem respeito a políticas regulatórias em sentido restrito, fiscalizatório, meramente formal, relacionado à UBS, os assuntos são processados. Quando se referem a outros assuntos que implicariam em controle social mais substantivo, em geral ultrapassam os limites de poder do Conselho. Nesse segundo caso observam-se duas situações

(1) os assuntos que dizem respeito a reclamações estruturais sobre as UBS ou sobre oferta insuficiente de serviços para atender a demanda dos 
usuários podem ser, e foram em alguns casos, atendidos de forma pontual, pelos gestores locais. Não existe, no entanto, permeabilidade consolidada dos fóruns de poder para essas reivindicaçōes. Essa falta de permeabilidade não legitima os CLS como centro de poder. Eles não têm canais institucionais que the permitam deliberar sobre o funcionamento da UBS;

(2) os assuntos dizem respeito a determinantes mais amplos, ligados a condições de vida, que ultrapassam os limites do setor saúde. Quando os assuntos deixam de ser setoriais podem ocorrer eventualmente ações intersetoriais isoladas, que conseguem atender ocasionalmente alguns problemas. Os resultados dessas ações, no entanto, são pifios, por causa da pouca eficácia das ações intersetoriais e das limitações do poder local em tratar essas questões.

Pode-se inferir que nos dois periodos analisados, 1993 a 1996 e 1997 a 1999, muitos assuntos de caráter regulatório tiveram encaminhamento adequado. Ampliou-se, de certa forma, mesmo limitadamente, a transparência, a fiscalização e a integração da comunidade com as UBS, com a criação dos conselhos. Os outros assuntos que entraram na agenda dos CLS, no entanto, quando tiveram algum encaminhamento institucional, esse foi episódico, circunstancial. Alguns foram tratados com voluntarismo por alguns atores locais, em ações de mutirão, atuando nos moldes clássicos da participação comunitária, conforme mencionamos no capítulo 2. É muito difícil avaliar o alcance desses canais de participação para a ampliação da consciência de direitos e de cidadania. Apesar de tudo não dá para desconsiderar a existência de avanços nessa área.

No periodo anterior, de 1993 a 1996, ocorreram tentativas de envolver a população e os técnicos locais na mudança do modelo de saúde tradicional, vigente nas UBS, com a realização de cursos de capacitação para gerentes de UBS e aplicação de métodos de análise epidemiológica 
local. A expectativa desse processo era de que desencadeasse a const. ução de novo modelo assistencial e gerencial, fato que acabou não ocorrendo, conforme já analisamos anteriormente.

Com a ampliação da autonomia de gestão, ocorrida no último período analisado, alternativas de mudança de modelo assistencial que estão sendo colocadas em prática, como o Programa de Saúde da Familia, têm como uma de suas estratégias o envolvimento da população e dos CLS nesse processo de mudanças. Outro exemplo é constituido pela elaboração das Cartas Sanitárias. Esse instrumento de análise da realidade sanitária, associado com a utilização de instrumentos de planejamento local, tem como um dos objetivos contribuir para a construção de novo modelo assistencial, e nele está implícita a participação da população através dos CLS. Até o momento, essa integração dos CLS com o processo de planejamento local - das UBS - e com o PSF ainda não ocorreu. Esse será um dos temas a ser tratado no próximo capítulo. 


\section{CAPÍTULO 5}

\section{MUNICIPALIZAÇÃO DA SAÚDE: AVANÇOS, OBSTÁCULOS NÃO-SUPERADOS E DESAFIOS PARA A NOVA AGENDA}

Os objetivos deste capitulo final são destacar os avanços propiciados pela municipalização da saúde, suscitar reflexões sobre a origem de obstáculos e dificuldades encontrados e ainda não superados ao longo do processo de descentralização da saúde no Brasil, e apontar desafios para a agenda da descentralização da saúde.

Os pressupostos utilizados por este estudo e apresentados no capitulo 3 foram os seguintes:

PRESSUPOSTO 1:

O deslocamento de poder propiciado pela municipalização da saúde, apesar de limitado por obstáculos que fogem do domínio dos atores locais, permite que os processos politicos que ocorrem no municipio interfiram positivamente no controle social e na ampliação do atendimento aos direitos em saúde.

PRESUPOSTO 2:

A capacidade de interferência do poder local no direcionamento das políticas de saúde está limitada a determinados assuntos. Esse rol de assuntos configura os limites do poder local. Seu descarte ou inclusão na agenda decisória local está condicionado à interação de complexos mecanismos de decisão e de participação política dos atores locais.

\section{PRESSUPOSTO 3:}

A prionização de assuntos e a formulação de políticas locais condizentes com o paradigma da Reforma Sanitária pode gerar conflitos no sistema de decisões e na interação dos atores. Gestores locais comprometidos e capacitados contribuem para a superação desses conflitos, com planejamento e condução adequada da politica.

PRESSUPOSTO 4:

A municipalização da saúde convive com dificuldades relacionadas ao 'que fazer' e ao 'como fazer'. Essas dificuldades não se devem apenas a obstáculos existentes no campo político-administrativo, mas também no campo teórico e prático da Reforma Sanitária. 
Esses pressupostos foram reafirmados pela investigação empírica?

Como assinalamos no capitulo 3 , eles não foram utilizados para serem taxativamente confirmados ou refutados, mas para contribuir na análise dos dados obtidos no estudo de caso. Isso será feito nos tópicos apresentados a seguir.

\subsection{A municipalização da saúde e o deslocamento de poder}

Os pressupostos 1 e 2 referem-se ao deslocamento de poder, aos limites do poder local e à participação política e à interferência dos atores locais no processo de municipalização. Tínhamos considerado, nesses pressupostos, que a municipalização da saúde possibilita interferência dos atores locais no direcionamento das politicas, apesar dessa interferência ser reservada a "um determinado rol de assuntos".

\subsubsection{O deslocamento de poder efetivamente ocorreu com a municipalização da saúde?}

Consideramos que sim, especialmente com a forma de gestão plena do sistema municipal, após a vigência da NOB SUS/96; este tem, no entanto, algumas peculiaridades que devem ser consideradas.

A primeira delas diz respeito às racionalidades que estão impulsionando e determinando a transferência de um poder centralizado para niveis mais periféricos. Consideramos que este estudo reafirma a existência de duas racionalidades distintas envolvidas com o processo de municipalização da saúde.

Uma dessas racionalidades relaciona-se à Reforma da Saúde. Os atores políticos favoráveis ao movimento sanitário utilizam-se da descentralização como estratégia de "democratizar a saúde". Nas arenas 
locais, procuram "ocupar" espaços e imprimir elementos de sua racionalidade - ou seja, expressar os interesses do movimento sanitáı ıo - às políticas em curso. Esses interesses interferem na agenda das decisões politicas, mostrando, na prática, que a reforma sanitária é favorecida com o processo de descentralização.

Por outro lado, essa agenda incorpora também a pauta de uma segunda racionalidade politica, que tem como elemento impulsionador o ajuste estrutural da economia. Nessa, a descentralização também é uma das estratégias, mas, nesse caso, tendo como fim o alcance de objetivos ligados à delegação de responsabilidades a niveis de governo mais frágeis e ao setor privado, em situação que favorece a restrição de direitos. Os reflexos, indiretos, nas arenas locais da saúde, podem ser traduzidos em limitaçōes à implementação de politicas publicas eqüitativas e redistributivas, por causa das dificuldades de financiamento que os novos responsáveis pelas politicas passam a ter. Passa a ocorrer, basicamente, uma transferência dos conflitos decorrentes da restrição dos direitos à saúde para as arenas locais, onde podem ser mais facilmente acomodados

Existem, portanto, associados ao deslocamento de poder, dois movimentos politicos distintos: o sanitário, que procura ampliar direitos e outro, que os limita. A origem deste último, que poderiamos denominar movimento contra-sanitário, tem sido atribuida a organizações internacionais que influenciam e pautam as agendas públicas nacionais. Entre essas destaca-se o Banco Mundial, cuja agenda "subordina a avaliação dos gastos em saúde à preocupação com a consistência macroeconômica dos países em processo de 'ajuste estrutural' (COSTA ${ }^{*}$ 1998, p.129). Segundo este autor, as mudanças propostas pelo Banco Mundial induzem à diminuição do Estado e ao fortalecimento do mercado para o oferecimento de cuidados à saúde, propugnando um "pacote básico de serviços clinicos e de saúde pública" (World Bank, 1993 apud COSTA ${ }^{36} 1998$, p.129). 
Diante dessas duas racionalidades e dessas duas agendas absolutamente distintas, o que conclui este estudo? Qual é a resultante desse processo?

Alguns autores costumam classificar o movimento sanitário, com o que concordamos, de contra-hegemônico $e$, nesse caso, o que denominamos acima de movimento contra-sanitário seria hegemônico. A interação desses dois movimentos no processo de municipalização é complexa. É possivel inferir, confirmando os pressupostos deste estudo, que o deslocamento de poder propiciado pela municipalização favorece o movimento sanitário. Quanto mais autonomia tiveram os gestores locais, mais se ampliou sua capacidade de governar e mais os aliados do movimento sanitário conseguiram avançar na implementação do projeto da reforma sanitária. Eles esbarraram, no entanto, em dificuldades estruturais que não se resolvem com a simples ampliação da autonomia.

Podemos dizer, de outra forma, que na interação dessas duas racionalidades não existem vencidos nem vencedores. Quanto mais o poder se desloca para os municipios, mais o movimento sanitário é favorecido. Isso não significa, porém, que a solução para a implementação do SUS e para o avanço da reforma sanitária seja apenas o deslocamento de poder, porque o poder local tem limites muito evidentes em sua capacidade de intervenção.

Segundo nosso ponto de vista, a existência desses limites se afigura como ponto importante a ser considerado na polêmica histórica entre municipalistas e não-municipalistas na área da saúde. $O$ núcleo da discussão não nos parece que deva ser a defesa ou a posição contrária à municipalização, ou seja, a questão não é saber se a municipalização é boa ou ruim. A polêmica, para nós, deve situar-se nos limites e possibilidades desse processo, considerando quais estratégias são as mais adequadas 
para a ampliação dessas possibilidades e para a atuação fora desses limites.

AS DIFICULDADES DA SAÚDE E SUAS DETERMINANTES

As caracteristicas, o alcance e os limites do deslocamento de poder ficaram evidenciados no estudo de caso. A gestão municipal mais autônoma - gestão plena do sistema municipal - aumentou a capacidade dos gestores locais para formular e implementar políticas. Essa maior autonomia permitiu a implementação de medidas gerenciais e assistenciais inovadoras que estão beneficiando os usuários. Os limites desses avanços, no entanto, ficaram evidentes na ımpotência dos gestores, mesmo quando claramente comprometidos com o movimento sanitário, para solucionar a maioria das reivindicações dos usuários. As reclamações dos atores locais descartadas ou não-resolvidas dizıam respeito a melhorar a eqüidade no acesso aos serviços médico-hospitalares, a dificuldades socioeconômicas dos usuários e a analise dos reflexos dessas dificuldades sobre suas necessidades de saúde - para, por exemplo, adquirir insumos e medicamentos ou desenvolver adequadamente práticas de autocuidados. Evidentemente, esse tipo de problema tem determinantes complexos, que não se resolvem apenas com gestões locais inovadoras.

Quais são as determinantes estruturais das dificuldades da saúde?

MENDES ${ }^{81}$ (1996, p. 18-26) refere-se à chamada "crise da saúde" ligada a "uma determinação estrutural que decorre da impossibilidade de conciliar, nos marcos da prática sanitária hegemônica, o conflito entre as forças expansivas do sistema de saúde com seus mecanismos de controle". Para este autor, as forças que exigem expansão do sistema de saúde são:

(1) a transição demográfica, que tem como conseqüência a ampliação do número de idosos e a elevação da demanda/necessidades por serviços de saúde; 
(2) a alteração epidemiológica que ocorre no país, denominada pelo autor de acumulação epidemiológica, que conforma um quadro complexo no qual as doenças crônico-degenerativas e causas externas se somam às doenças infecciosas, aids, dengue e cólera, entre outras;

(3) a medicalização da sociedade, que dissemina o conceito de que todos os padecimentos humanos são medicalizáveis, o que impulsiona ainda mais o crescimento da oferta/demanda por serviços médicos;

(4) a urbanização e seus reflexos na deterioração das condições de vida;

(5) a incorporação tecnológica descontrolada e seus reflexos na ampliação dos custos da saúde;

(6) o incremento da força de trabalho em saúde e a pressão pela incorporação desses profissionais ao mercado de trabalho; e

(7) o corporativismo empresarial e profissional, cujo comportamento pressiona o sistema de saúde para obter mais lucros, independentemente das necessidades sociais de saúde.

Esse amplo e complexo leque de dificuldades dá uma dimensão dos obstáculos que dificultam o processo de mudanças que envolve o setor. É necessário caracterizar melhor de que forma a municipalização da saúde tem influido na implementação de políticas que possam ter impacto em alguns desses obstáculos. Para essa caracterização, vamos considerar, a seguir, o comportamento das políticas distributivas, redistributivas e regulatórias afetas ao setor saúde no transcorrer do processo de municipalização analisado.

\subsubsection{As políticas distributivas e redistributivas}

Utilizando o esquema de Lowi, apresentado no capítulo 3, como guia de referência, podemos classificar as políticas locais de saúde em distributivas, redistributivas e regulatórias. As regulatórias serão tratadas no próximo tópico. 
As politicas distributivas dizem respeito à expansão de equipamentos públicos na área da saúde.

As politicas redistributivas no contexto da municipalização, segundo nosso ponto de vista, podem ser divididas em dois conjuntos distintos: (1) as relacionadas à assistência médico-hospitalar ou outros elementos que habitualmente compõem o setor saúde e (2) as relacionadas às queixas que têm como determinantes fatores de desigualdade mais flagrantes, tais como a falta de recursos econômicos para autocuidados ou aquisição de insumos em disputa no mercado.

O primeiro conjunto vamos denominar politıcas redistributivas setoriais e o segundo, politicas redistributivas extra-setoriaıs. As setoriais não se referem à simples expansão de equipamentos püblicos, mas à sua expansão, tendo como meta a equidade. Ampliar a oferta para os que "não têm" acesso aos serviços assistenciais. Essa redistribuição relaciona-se às determinantes do setor saúde, por isso estão sendo chamadas de setoriais. As extra-setoriais também se destinam a ampliar a oferta dos que "não têm", embora incluam aspectos de interesse para a saúde fora dos limites desse setor.

De acordo com essa classificação, seguem-se exemplos dessas politicas:

Politicas distributivas: ampliação geral da oferta de assistência médico-hospitalar e mudanças na programação dos serviços sem alterar o modelo vigente;

Politicas redistributivas setoriais: ampliação seletiva - privilegiando grupos de risco e segmentos sem acesso - da assistência médicohospitalar; ampliação do acesso a medicamentos $\mathrm{e}$ insumos a desassistidos sociais e medidas concretas que tenham como meta a eqüidade na alta complexidade; 
Politicas redistributivas extra-setoriais: ligadas às determinantes de saúde relacionadas às condições gerais de vida - emprego, salário, habitação e lazer.

De acordo com $\operatorname{COSTA}^{36}$ (1998, p.105), a descentralização decisória aumenta a capacidade de encaminhamento de politicas distributivas, afirmando que "as políticas governamentais distributivas tendem a favorecer arenas decisórias descentralizadas e multicentradas".

As políticas redistributivas, por outro lado, segundo nosso ponto de vista, nem sempre são favorecidas por processos decisórios descentralizados. Isso só ocorrerá se o deslocamento de poder estiver acompanhado de condições de implementação dessas políticas, se os mecanismos de decisão estiverem permeáveis aos excluidos dos seus beneficios e se os excluidos ou os que defendem seus interesses se fizerem representar com real possibilidade de influenciar o processo político. Como os excluidos sociais no Brasil são, em sua expressiva maioria, "desorganizados sociais", e como nem sempre seus representantes representam, de fato, seus interesses, a influência dos segmentos excluidos nos processos politicos descentralizados geralmente é reduzida.

Como se deu a implementação dessas politicas em Marília no transcorrer do processo de municipalização?

As politicas distributivas locais cresceram. A ampliação de unidades básicas de saúde e a expansão de oferta de serviços do municipio foi bem expressiva. Houve substituição do clássico modelo do INAMPS, no qual os médicos credenciados atendiam os previdenciários em seus consultórios, por modelo em que as UBS passam a responsabilizar-se pela atenção básica e as unidades especializadas, públicas e credenciadas, pela atenção especializada. Além disso, a "prevenção de doenças" deslocou-se da rede estadual e federal para as UBS, que também passaram a desenvolver 
programas. Em virtude da universalização - embora "excludente" como mencionamos no capítulo 1 - incorporaram-se segmentos não assistidos pelo modelo anterior.

Essa expansão deu-se de forma a agradar ambos os grupos de atores em interação - usuários e prestadores de serviço -, pois, como afirma Costa, "as políticas setoriais com esse perfil (distributivas) pressupõem uma ativa opção por veneficiar todos os participantes da arena de poder, valendo-se de uma pulverização de estímulos institucionais" (1998, p.105) Não surgiram conflitos entre usuários e prestadores quando essas politicas ocuparam a pauta de decisões. Nenhum dos componentes do processo decisório se posicionou contra a expansão de equipamentos públicos na área da saúde. Não se estabeleceram vetos de um grupo a outro nas reivindicações propostas.

As políticas redistributivas, por outro lado, apesar de também terem crescido, cresceram menos. Ficou evidenciada a preocupação dos gestores por ampliar a oferta de serviços para segmentos desassistidos, como foi o caso, por exemplo, de implantar PSF nas áreas mais pobres do município, de atender demandas prioritárias de usuários de UBS em áreas de atenção médica especializada e de regular os serviços contratados para que a eqüidade na utilização da oferta pudesse ser ampliada. O crescimento da "redistribuição setorial" foi tolhido pela baixa governança - aqui entendida como a dificuldade de implementar medidas dessa natureza, pela falta de recursos materiais e financeiros para fazê-lo - e pela baixa governabilidade, resultante do domínio limitado que os gestores têm sobre as causas da iniqüidade nos diferentes niveis de atenção do sistema de saúde.

As politicas redistributivas extra-setoriais não tiveram relação direta com a municipalização da saúde. Não dispomos de dados para avaliar o comportamento das políticas municipais de setores que não sejam o da saúde; porém, se durante esse periodo houve crescimento dessas políticas, 
isso não foi induzido pelo deslocamento de poder propiciado pela municipalização. Nos depoimentos obtidos nas entrevistas e por intermédio de outros dados coletados foi possivel verificar, no entanto, que o estimulo, esparso, ao desenvolvimento de atividades intersetoriais ocorreu com alguma eficácia em alguns casos.

Na Figura 20 procuramos esquematizar, de acordo com o nosso entendimento a respeito do processo de municipalização da saúde em Marília, o padrão de comportamento dessas políticas - distributivas, redistributivas setoriais e redistributivas exta-setoriais - durante a ampliação da autonomia de gestão municipal. O esquema mostra a relação entre a autonomia de gestão e o comportamento dessas políticas. Com a ampliação da autonomia, que ocorreu ao longo do processo de municipalização, as políticas distributivas - de aumento geral na oferta de serviços municipais de saúde - crescem de forma mais expressiva. As politicas redistributivas setoriais - de redução das iniqüidades presentes no setor saúde - no entanto, cresceram menos, pois estão limitadas por obstáculos diversos que não podem ser totalmente superados. As políticas redistributivas extrasetoriais - ligadas a condições de vida, por exemplo - apresentam alteração menor, pois conservam pouca relação com a ampliação da autonomia de gestão. 


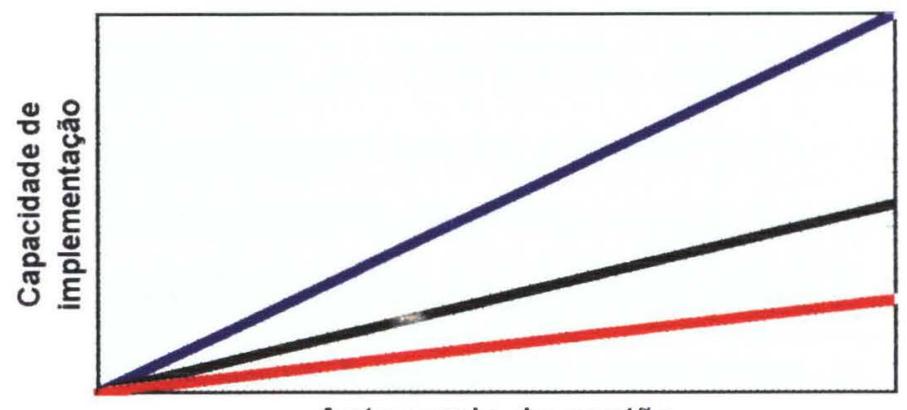

Autonomia de gestão

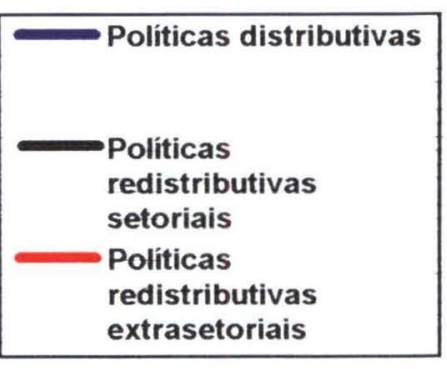

extrasetoriais

Figura 20 - Relação entre a capacidade de implementação de políticas distributivas e redistributivas e a autonomia de gestão propiciada pela municipalização da saúde.

Nossa experiência diz que o padrão geral mostrado na figura 20 apresenta variações nos diferentes municípios, que dependem de contextos e conjunturas particulares, podendo algumas políticas avançar mais e outras menos, sendo esse fato que diferencia as diversas experiências municipais, mais bem sucedidas ou menos bem sucedidas. Visando tornar mais didática a explicação da nossa compreensão sobre os diferentes comportamentos que podem ser observados nessas experiências, vamos expor, a seguir, duas situações polares hipotéticas.

\section{MUNICÍPIOS QUE REPRODUZEM O MODELO HEGEMÔNICO}

Os municípios que se preocupam simplesmente em reproduzir o modelo de saúde centrado na atenção médica e no consumo de ações curativas podem ter crescimento apenas das políticas distributivas. Isso ocorre com aqueles que têm como principal estratégia, por exemplo, a criação de serviços de pronto atendimento para atender a demanda reprimida. Essa não é, lamentavelmente, uma situação incomum. Já nos referimos, nos capítulos precedentes, a autores que criticam a municipalização da saúde pelo fato de que ela reproduz o modelo hegemônico. Nesses municípios as duas linhas da Figura 20 que 
representam as políticas redistributivas - setoriais e extra-setoriais - estarão menos inclinadas e mais próximas do eixo horizontal, mesmo nas sitı ações em que já ocorreu expressiva elevação da autonomia de gestão

Nessa situação podem existir casos extremos nos quais nem sequer as politicas distributivas crescem com a ampliação da autonomia de gestão, sendo representados pelos municipios "compradores de ambulâncias" e que transferem exageradamente os pacientes, mesmo em situações de baixa complexidade, para outros municipios.

\section{MUNICIPIOS QUE PROCURAM INOVAR E MUDAR O MODELO DE SAÚDE}

Os municipios que têm como meta a expansão de serviços aos que mais necessitam e desenvolvem açōes de proteção à vida aproveitam a ampliação da autonomia de gestão para fazer crescer as politicas redistributivas setoriais e extra-setoriais.

Mesmo não sendo situação freqüente, nesses últimos sete ou oito anos, que foi quando a autonomia de gestāo mais se ampliou, diversos municipios conseguiram inovar e obter bons resultados na implementação de politicas, como comprovaram diversos estudos de caso já citados.

Nessas situações, seria observada na Figura 20 maior inclinação das três linhas do gráfico. A ampliação da autonomia permitiria aumento mais expressivo na capacidade de implementação para os três tipos de políticas

É importante ressaltar que, de acordo com o padrão de comportamento, estamos considerando que, mesmo nos municipios inovadores, ocorrem restrições à implementação de politicas redistributivas, condicionadas pelos limites do poder local, dificultando a ação redistributiva dos municipios 
Qual desses dois padrões melhor se aplicaria à situação de Marilia?

O estudo empírico por nós realizado mostra claramente que, especialmente após o município ter entrado em gestão plena do sistema municipal, Marilia está procurando inovar e substituir o modelo de saúde hegemônico. O município tem procurado utilizar as possibilidades propiciadas pela municipalização da saúde da melhor forma possivel, mesmo estando tolhido pelos limites do poder local.

É necessário identificar, dentro desses limites, as condições mais favoráveis e que contribuem para ampliar a viabilização das políticas de interesse do SUS aproveitando ao máximo as potencialidades da municipalização da saúde. Essas condições serão analisadas neste capítulo.

Também è importante ressaltar que nas arenas estudadas conselhos de saúde e governo local - ocorreram poucos conflitos decorrentes do não-atendımento a políticas ligadas à eqüidade em saúde -ou seja, às politicas redistributivas setoriais e às ligadas à eqüidade social, representadas pelas politicas redistributivas extra-setoriais. Esses conflitos, quando aconteceram, não se manifestaram com muita visibilidade; em outras palavras, as reclamações e queixas dos usuários que "não têm acesso" não se transformaram em elementos de influência e pressão que gerassem conflitos nas arenas estudadas.

\subsubsection{As políticas regulatórias, a participação e o controle social}

As políticas regulatórias, no contexto da municipalização da saúde, referem-se à implementação de medidas que têm como objetivo impor sanções a quem infringir as regras do SUS, garantindo que as normas de interesse público sejam cumpridas. Trata-se, em suma, de promover melhor regulação pública na execução dos serviços, para que eles não se desviem de suas finalidades 
Essa regulação deve ser realizada de forma transparente pelos gestores locais, através de revisão de mecanismos contratuais e controle dos serviços executados, procurando enquadrar esses serviços às normas estabelecidas, e propiciando acompanhamento e fiscalização da população. As deliberações e decisões dos gestores devem ser submetidas à aprovação do Conselho Municipal de Saúde.

Como se processaram essas políticas no transcorrer do processo de municipalização? Ampliou-se a capacidade de formular/implementar políticas regulatórias? O controle público foi aperfeiçoado?

A nosso ver, essas questōes devem ser analisadas sob três aspectos: (1) eficiência/eficácia das ações de controle/auditoria implementadas pelos gestores municipais; (2) institucionalização dos mecanismos de controle social, que denominaremos controle social formal, e (3) eficácia dos mecanismos de controle social implementados, que chamaremos de controle social substantivo.

Com respeito à eficiência/eficácia das ações de controle/auditoria, a ampliação da autonomia de gestão está sendo acompanhada pelo aperfeiçoamento das ações de controle por parte do gestor?

Nós acreditamos que em Marília isso está ocorrendo. A Secretaria de Saúde está construindo, ao longo desse processo, nova estrutura de controle, e as responsabilidades crescentes que passa a assumir têm funcionado como estímulo para que essa estrutura se aperfeiçoe. Esse setor tem sido considerado "estratégico" pelos gestores municipais, porque é através do adequado controle dos gastos e da avaliação da qualidade dos serviços executados que se viabilizam mudanças mais consistentes no sistema de saúde. É através da detecção de distorções nos gastos, e correção dos mesmos - como por exemplo na utilização e autorização de 
AlHS para procedimentos passiveis de realização ambulatorial - que se pode gastar menos do que a média histórica de gastos e possibilitar que as "sobras" sejam redirecionadas para financiar projetos inovadores. Além disso, alterações no modelo assistencial, notadamente na revisão dos contratos e convênios com os prestadores de serviço, modifica o "modelo de gastos" e melhora a eficiência na utilização dos recursos do SUS. Em nosso estudo não quantificamos o resultado dessas medidas em Marilia e portanto não podemos dimensionar a eficiência/eficácia das mesmas. O fato, porém, de terem constituido pontos prioritários na agenda dos governantes locais do período de 1997-1999 conforme destacaram nas entrevistas realizadas e, além do mais, de estarem desenvolvendo projetos e parcerias - destacadas em nosso estudo - que só seriam possiveis com a revisão no modelo tradicional de gastos do SUS, nos induz a pensar que essas ações estão dando resultados em Marilia.

O controle social formal, igualmente, foi bem sucedido. Os instrumentos e mecanismos institucionais utilizados para incorporar novos atores ao processo decisório local - conselhos e conferências de saúde consolidaram-se, como mostraram os dados que apresentamos. O Conselho Municipal de Saúde está tendo funcionamento regular, com regimento e normas legalmente constituidas e tem feito suas reuniões com periodicidade adequada. Foram constituidos Conselhos Locais de Saúde, tendo sido, portanto, ampliados, além do exigido, os canais de participação da população. As conferências de saúde também tem sido realizadas com utilização de critérios e regras democráticas e de acordo com a periodicidade preconizada pelas normas legais.

Os achados empíricos mostram que não apenas foi institucionalizada a participação popular através dos conselhos e conferências, como também as contas do fundo municipal e os convênios passaram a ser mais bem fiscalizados. 
O mesmo não ocorreu com o controle social substantivo. A eficácia dos mecanismos de controle social não foi alcançada na medida que se esperava. O êxito do "formalismo" da participação de prestadores de serviço, usuários e profissionais de saúde, entre outros, não ocasionou influência significativa no processo decisório. Deve-se ressaltar, como fazem diversos autores, entre os quais SILVA e col. ${ }^{10 x}$ (1999, p.39), que a participação no

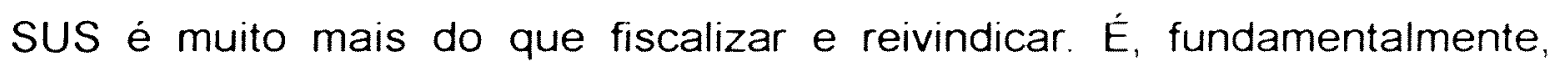
deliberar em conjjunto e partilhar o poder, e isso não está ocorrendo

Existe um descrédito, perceptivel nas entrevistas realizadas com os gestores, sobre o alcance das medidas fiscalizatórias implantadas. Consideramos que esse descrédito se deve ao fato de que a dimensão institucional de avanço, reconhecida pelos atores locais como tendo efetivamente ocorrido, e que constitui um dos componentes do que denominamos accountability, não tem sido suficiente para satisfazer as expectativas desses atores.

Nós, igualmente, reconhecemos essas medidas como importantes, porém o respeito ao cidadão e a responsabilidade social em saúde estão um passo à frente dessas medidas. Podem-se criar conselhos e realizar conferências obedecendo ao rito formal exigido pelas normas vigentes, sem necessariamente democratizar as decisões. Existe risco de que se promova tutela desses canais de participação por parte do poder executivo. Indicamse conselheiros ou cooptam-se os mesmos, e produz-se um "faz-de-conta" que cumpre as exigências da lei. Em Marilia não observamos isso. Observou-se um esforço no sentido de promover verdadeira participação. Por que, apesar disso, seu alcance foi e está sendo limitado?

Essa não é, evidentemente, uma situação apenas observada em Marilia; arriscariamos a dizer que ocorre em praticamente todos os municipios. Em nossa opinião, a tentativa de democratizar as decisões está presente apenas em algumas das arenas de poder. Outras, diferentes 
daquelas em que a participação está institucionalizada, ainda se mantêm impermeáveis ao deslocamento de poder propiciado pela municipalização Esse assunto foi analisado por CECÍLIO ${ }^{28}$ (1999), que dá as seguintes explicações para os "serviços de saúde (funcionarem) como verdadeiras 'caixas pretas' quando se pensa o controle dos usuários sobre a qualidade da assistência prestada":

(1) as organizações de saúde são 'arenas' onde se disputam distintos projetos politicos: os dirigentes - que buscam legitimidade politica - os trabalhadores de saúde - que buscam salários e boas condições de trabalho -, existindo entre estes distintos interesses, inerentes a cada categoria profissional, e os usuários, sob cujo rótulo se abrigam diferentes expectativas e interesses;

(2) a falta de clareza do conceito de qualidade, que deveria considerar tanto a opinião dos usuários quanto os critérios científicos, dos técnicos, mas que na prática os primeiros se acabam submetendo aos segundos, e

(3) o modelo de gerência habitualmente adotado pelo setor público, que não explicita a missão e os objetivos organizacionais e não institui mecanismos reguladores de avaliação de desempenho e de prestação de contas. Além disso os médicos resistem a qualquer controle externo ao seu trabalho, exercendo o monopólio do saber e da prática de cura.

Concordamos com esse autor no que diz respeito aos limites do controle social em saúde, que ficaram bem-evidenciados em nosso estudo de caso. As diversas unidades que compōem o sistema de saúde ainda estão alheias ao controle da sociedade. Os diversos interesses presentes nessas organizações e os pactos que se estabelecem entre os atores é que determinam o funcionamento das unidades. A lógica do SUS, com seus principios de equidade, respeito ao usuário, qualidade técnico-cientifica etc. não está prevalecendo no confronto com as diferentes lógicas ligadas a esses distintos interesses.

Para superar essa fragilidade do controle social em saúde haveria necessidade do fortalecimento dos "interesses do SUS" no interior das organizações. Não basta estarem esses interesses presentes em conselhos 
e conferências de saúde. Esses são espaços importantes, mas insuficientes para garantir que ocorram as mudanças necessárias para melhorar a qualidade na atenção à saúde. Na singularidade das organizações, onde se dá o contato entre o usuário e o trabalhador em saúde, os interesses do usuário também devem estar representados.

Observou-se, no entanto, no estudo de caso, influência positiva da municipalização no interior de uma das organizações de saúde analisadas: a Santa Casa local. Nesse hospital está ocorrendo inicio de mudança na lógica de gestão, na qual os interesses do SUS, aparentemente, estão sendo fortalecidos. A reengenharia interna observada nesse hospital o está fazendo rever elementos de sua doutrina e de seus valores, procurando construir nova pactuação de interesses. O reconhecımento que seus diretores estão fazendo dos distintos interesses ali presentes, legitimando-os mas submetendo-os à missão do Hospital, que por sua vez procura ser coerente com a lógica do SUS, e consequentemente com os interesses dos usuários, é representativo de um processo positivo de mudanças.

Podemos considerar, com base nos argumentos apresentados, que a municipalização da saúde, mesmo de forma ainda incipiente, constituiu-se, ao menos em Marilia, como um indutor de mudanças organizacionais. Como afirma $\mathrm{KISIL}^{60}(1998$, p.3) "a reforma do setor saúde pela qual vem passando - Brasil é em si mesma um agente provocador de MUDANÇA ORGANIZACIONAL que afeta todo o Sistema de Saúde”. Segundo esse autor, um fator de mudança das organizações é o surgimento de forças desestabilizadoras de seu status quo. Essas forças podem situar-se dentro da própria organização - ou seja, no seu "ambiente interno" - ou fora dele, no denominado "ambiente externo".

Em nosso ponto de vista a municipalização da saúde induz à mudança nas organizações de saúde públicas e privadas do SUS em virtude da nova relação de poder que se estabelece entre os prestadores de serviço 
e o gestor público, na qual a lógica do SUS é fortalecida. Esse movimento de mudanças, no entanto, como nos referimos há pouco, nos parece, ainda, incipiente. Um dos desafios que temos de superar na construção do SUS é a aceleração dessas mudanças. Esse tema será analisado no último tópico deste capitulo.

De acordo cum essas considerações, o comportamento das políticas regulatórias observado em Marília pode ser ilustrado sob a forma esquematizada na Figura 21.

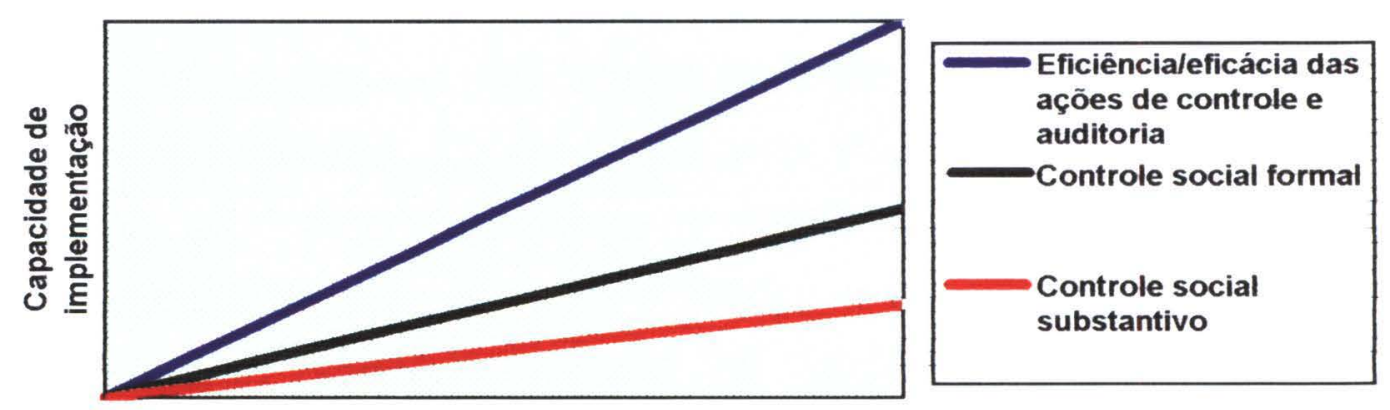

Autonomia de gestão

Figura 21 - Relação entre a capacidade de implementação de políticas regulatórias e o deslocamento de poder propiciado pela municipalização da saúde.

Observamos nessa figura que o deslocamento de poder favoreceu o aperfeiçoamento das medidas de controle e auditoria implementadas pelo gestor e a institucionalização das medidas de controle social, ampliando o que optamos por denominar controle social formal. Mas o controle social substantivo, que poderia exercer impacto positivo na ampliação da eqüidade, hegemonizando a lógica preconizada pelo SUS ao conjunto dos serviços de saúde, avança menos. 


\subsection{A municipalização da saúde e a liderança do processo de mudanças}

O pressuposto 3 deste estudo valoriza o papel de gestores locais comprometidos e capacitados na liderança do processo de mudanças. A influência de lideres locais na implementação do projeto da reforma sanitária pode ser analisada em três diferentes perspectivas: (1) na identificação dos líderes com esse projeto; (2) na capacidade de articulação e de visão de governo, e (3) nas características pessoais do líder.

A IDENTIFICAÇÃO DOS LÍDERES LOCAIS COM O PROJETO DA REFORMA SANITÁRIA

É necessário que atores politicos impulsionem, liderem a Reforma Sanitária nos espaços concretos onde ela se realiza. ESCOREL (1987 apud SILVA JR ${ }^{107} 1998$, p.23) refere-se a esse tema, atribuindo à Saúde Coletiva a existência de dois campos: o teórico e o politico. Segundo esse autor, o Movimento Sanitário, situado no segundo campo, utilizou-se de três caminhos para viabilizar a reforma: o legislativo/parlamentar, o sóciopolitico, que procurou envolver a sociedade nas questões de saúde e o institucional.

No estudo de caso, em Marilia, o papel exercido pelos aliados do movimento sanitário, dispersos nas instituições locais, constituiu fator importante para impulsionar o processo de descentralização. Eles atuaram de forma mais organizada no campo institucional, mas conseguiram consolidar aliados ao projeto da reforma em outras campos de atuação legislativo/parlamentar e sóciopolítico - também.

\section{A CAPACIDADE DE ARTICULAÇÃO E DE VISÃO DE GOVERNO DOS LÍDERES}

A liderança necessária a um adequado processo de mudanças pressupõe competência para governar. $\operatorname{MATUS}^{16}(1996$, p.51) afirma: " ... o líder só dirige se for capaz de ver além da curva, além do que vêem seus 
seguidores". De acordo com Matus, o governante, para governar, deve articular constantemente três variáveis: projeto de governo, governabilidade e capacidade de governo. Essas variáveis compõem os vértices do Triângulo de Governo (Figura 22), no qual uma depende das outras para que se mantenham numa relação harmônica.

\section{PROJETO DE GOVERNO}

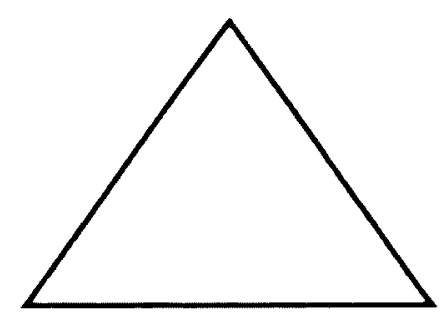

GOVERNABILIDADE

CAPACIDADE DE

GOVERNO

Figura 22 - Triângulo de governo de Matus (referência: Matus

C. Adens, senhor presidente: governames governados $3^{3}$ ed

Sào Paulo: FUNDAP; 1996 p. 51).

A capacidade de governo é constituida pelo dominio da teoria, métodos e técnicas de planejamento de que a equipe de governo dispõe e que the facilita governar.

O projeto de governo diz respeito ao "conteúdo propositivo dos Projetos de Ação" que a equipe de governo pensa em colocar em prática.

A governabilidade é a relação entre as variáveis controladas e não controladas pela equipe de governo.

A ampliação da autonomia de gestão propiciada pela municipalização da saúde aumenta a governabilidade dos dirigentes locais. Eles passam a controlar mais recursos de poder - recursos financeiros federais, contratos e 
convênios com prestadores de serviço, autonomia gerencial de unidades de saúde etc.

Em Marilia foi possivel identificar algumas características das três variáveis que compõem o triângulo de governo da saúde municipal, no contexto da municipalização da saúde:

(1) Governabilidade as novas prerrogativas obtidas com a ampliação da autonomia de gestão aumentaram o poder dos gestores municipais. Eles passaram a controlar variáveis que anteriormente estavam sob o controle de outros niveis de governo. Isso, no entanto, não deu aos gestores todas as condiçōes de solucionar numerosos problemas de saúde, como destacamos no capitulo 4 e nos tópicos anteriores a este. Não lhes permitiu solucionar, por exemplo, muitas queixas de usuários especialmente no campo da eqüidade da atenção - e de prestadores, na correção de remuneração distorcida de valores de remuneração.

(2) Projeto: os componentes do projeto de governo para a área da saúde têm sua articulação lógica construida ao longo do processo. Se o fazem, fazem-no muitas vezes por intermédio de "experimentações" e readequações sucessivas, pois o ambiente em que se processam as mudanças é muito instável e exige freqüentes adaptaçōes. A municipalização da saúde traz consigo componentes de um projeto, representados pelas políticas formuladas ou tornadas relevantes pelos niveis de governo centrais (federal e estadual). O projeto completo para a área da saúde, no entanto, deve ser elaborado localmente e representa a união dos componentes formulados pelos outros níveis com as ações inovadoras propostas pelos gestores locais. Deve haver, em sintese, uma articulação conduzida pelo núcleo local onde se processam as mudanças. É necessário registrar que o projeto UNI desempenhou o papel de projeto de governo em um dos periodos analisados, conforme já referimos. 
(3) Capacidade de governo: habitualmente os municipios não têm capacidade de implementar as ações de governo condizentes com todas as responsabilidades que assumem. Um dos primeiros desafios que os gestores locais enfrentam é desenvolver esse vértice do triângulo de governo. A municipalização da saúde induz os municípios, em decorrência das novas responsabilidades que assumem, a ampliar sua capacidade de governar.

O nosso estudo de caso mostrou que, nos primeiros periodos analisados, quando a autonomia de gestão era menor, os governantes locais desenvolviam poucos projetos. Com a maior autonomia obtida no último periodo cresceu um dos vértices do triângulo: a governabilidade. Com mais poder, mesmo que esse deslocamento de poder tenha sido seletivo e insuficiente, como mencionamos, o desafio dos que estavam liderando o processo de mudanças era fazer crescer os outros vértices do triângulo, para manter a harmonia. Ou seja, precisavam ter um projeto viável e condizente com seu poder de gestão e sua capacidade de implementá-lo.

Após o município de Marilia entrar em gestão plena do sistema municipal, os governantes locais procuraram implementar o projeto que consideravam mais adequado à realidade local. Estavam conscientes da necessidade de ampliar sua capacidade de governar, o que significava, em sintese, investimento na capacitação de recursos humanos e aperfeiçoamento da estrutura administrativa.

A capacidade de implementação desse projeto ampliou-se, como mostraram os achados empíricos. Os gestores conseguiram melhorar e utilizar de maneira apropriada sua capacidade de governo. Os governantes locais, de 1997 a 1999, implantaram diversos projetos novos, muitos até inovadores, pois souberam utilizar-se adequadamente do contexto de mudanças da reforma sanitária - de recursos adicionais para o PSF, por 
exemplo - e da ampliação de sua governabilidade que thes permitiu formular projetos próprios -, entre os quais se destacam intervenções na média e alta complexidade assistencial médico-hospitalar.

\section{CARACTERISTICAS PESSOAIS DO LIDER}

Além da necessária visão e capacidade de articulação política, a capacitação pesscal para conduzir as mudanças também não pode ser desconsiderada. De acordo com STEVENS ${ }^{117}$ (1991, p.35), existem diferentes estilos de liderança adequada, que variam com os diferentes contextos. Em qualquer deles é conveniente, segundo esse autor, que estejam presentes seis características no lider: (1) senso de justiça; (2) capacidade de decidir; (3) comportamento ético; (4) capacidade de condução politica; (5) capacidade de transmitir confiança e (6) responsabilidade.

O estudo de caso não dispõe de dados que permitam analisar se essas caracteristicas estiveram presentes ou ausentes nos atores locais que lideraram as mudanças. Foi possivel inferir, no entanto, com base nos resultados das entrevistas, que, no último periodo analisado - de 1997 a 1999 - a capacidade do secretário de saúde para conduzir as mudanças transmitiu confiança e segurança aos outros atores locais. As entrevistas ressaltaram características pessoais positivas do secretário como fatores importantes para o possivel êxito na implantação da nova política: visão, clareza de propósitos, responsabilidade, seriedade e conhecimento do tema.

Consideramos, em sintese, que o pressuposto 3 foi parcialmente confirmado pelo estudo de caso. A capacitação e as características pessoais dos gestores que lideram o processo de mudanças é um fator importante para a condução mais adequada do processo de municipalização. $\dot{E}$ necessário, no entanto, fazer uma ressalva: conforme ressaltamos em tópicos anteriores, praticamente não ocorreram conflitos na interação entre 
os atores, como supunha o pressuposto 3 , e ele não foi, portanto, totalmente confirmado.

\subsection{A municipalização da saúde e as dificuldades de mudança do modelo assistencial}

O pressuposto 4 considera que as dúvidas e incertezas do campo teórico da Reforma Sanitária explicam algumas das dificuldades que se manifestam nos espaços concretos onde se processa sua implantação. A consolidação de novas práticas sanitárias, além de enfrentar obstáculos politicos e institucionais, enfrenta também, como afirma PAIM"1 (1997, p.16), desafios teóricos e práticos ainda não superados. Esses desafios decorrem de dificuldades de transformar em experiências concretas as diretrizes fundamentais da nova politica preconizada pela Reforma, como a utilização do conceito ampliado de saúde e a ruptura com o modelo assistencial negemônico.

Existe na literatura nacional e internacional expressivo acúmulo de publicações sobre o tema modelo assistencial. As estratégias de intervenção preconizadas pela Reforma Sanitária Brasileira e que visam incorporar outros paradigmas ao atual modelo, no entanto, carecem de bases empiricas consistentes.

PAIM $^{94}$ (1999, p. 485) refere-se às formas de organização da atenção dos modelos assistenciais hegemônico e alternativos no Brasil. A diferença entre esses dois modelos, mostrada na Figura 23, consiste fundamentalmente no seguinte:

(1) O modelo médico-assistencial hegemônico organiza-se a partir da demanda espontânea ou expande os seus serviços visando captar clientela e estimular o consumo (caracterizando o modelo médicoassistencial privatista), enquanto os modelos alternativos procuram atender a demanda organizando a oferta de serviços; 
(2) O modelo médico-assistencial hegemônico procura orientar-se para atender o que pressupōe serem necessidades de saúde, visando resolver problemas nessa área através de campanhas ou programas sanitários e através das atuações clássicas das Vigilâncias Epidemiológica - no combate às doenças transmissiveis - e Sanitária no controle de riscos e na proteção à saúde. Os modelos alternativos procuram estruturar-se para atender as necessidades por intermédio de diferentes alternativas: açōes programáticas em saúde, vigilância em saúde, estratégia de saúde da familia, politicas públicas saudáveis etc.

\begin{tabular}{|c|c|c|}
\hline \multirow[b]{2}{*}{$\begin{array}{l}\text { ORGANIZAÇÃO DA } \\
\text { ATENÇÃO }\end{array}$} & \multicolumn{2}{|c|}{ MODELOS ASSISTENCIAIS } \\
\hline & HEGEMÔNICOS & ALTERNATIVOS \\
\hline DEMANDA/OFERTA & $\begin{array}{l}\text { Modelo medico-assistencial } \\
\text { privatista }\end{array}$ & Oferta organizada \\
\hline \multirow[t]{4}{*}{ NECESSIDADES } & Campanhas sanitárias & $\begin{array}{l}\text { Ações programáticas em } \\
\text { saúde }\end{array}$ \\
\hline & Programas especiais & $\begin{array}{l}\text { "estratégia da saúde da } \\
\text { família" }\end{array}$ \\
\hline & PACS/PSF & Vigilância em saúde \\
\hline & $\begin{array}{l}\text { Vigilância epidemiológica } \\
\text { Vigilância sanitária }\end{array}$ & Políticas públicas saudáveis \\
\hline
\end{tabular}

Figura 23 - Organização da atenção e modelos assistenciais hegemônicos e alternativos (retirado de: Paim JS. A Reforma Sanitária e os Modelos Assistenciais. In: Rouquayrol MA, Naomar Fo A. Epidemiologia \& Saucde. $5^{a}$ ed. Rio de Janeiro: Medsi; 1999. p.485.

A experimentação de modelos assistenciais no Brasil tem sido desenvolvida em alguns municipios e regiões brasileiras e constituem, muitas vezes, experiências inovadoras, benéficas para a população e positivas como experiências empíricas. O processo de descentralização aumentou a frequência desses experimentos, como afirma CAMPOS ${ }^{21}$ (1997, p.116): "(com) a municipalização surgiram inúmeras experiências alternativas de construção e operacionalização de política de saúde". Esses experimentos, no entanto, ainda não constituem estratégias definitivamente consolidadas. É necessário reconhecer que a implantação do SUS não tem conseguido alterar substancialmente as práticas curativo-individuais do modelo hegemônico.

Essa preocupação com a reorganização da assistència e mudança do modelo assistencial no SUS não é recente. Há quase uma década 
TEIXEIRA (1992 apud SILVA JR ${ }^{107}, 1998$ ) afirmava: " ... não se tem, durante os anos 80, nem agora - 1992 - uma clara concepção acerca dos modelos assistenciais e organizacionais de prestação de serviço de saúde no SUS" (p. 25).

Essa realidade não alcançou mudanças substanciais nos últimos anos. Os projetos estruturantes do SUS não conseguiram, ainda, superar esse desafio. $\mathrm{Na}$ implantação de novas práticas sanitárias, a dificuldade mais evidente é a efetiva incorporação do conceito ampliado do processo saúde-doença, que signifique a ruptura com o reducionismo do modelo hegemônico. Além de divergências que se manifestam quando se procura compreender os complexos fenômenos relacionados às causas do adoecer e de morrer, são grandes as dificuldades de mudar as práticas sanitárias (TARRIDE ${ }^{119}$ 1998, p. 25-29).

VAITSMAN (1992 apud SILVA JR $\left.{ }^{107}, 1998\right)$ ressalta com propriedade uma das dimensões dessas dificuldades: "Uma concepção de saúde não reducionista deveria recuperar o significado do individuo em sua singularidade e subjetividade na relação com os outros e com o mundo" ( $p$. 33).

O Programa de Saúde da Família (PSF), concebido pelo Ministério da Saúde com o propósito de modificar o modelo de assistência, conforme já abordamos no capítulo 1 , vem se consolidando nos últimos anos como a principal estratégia estruturante da inversão das práticas sanitárias no SUS, com a adesão cada vez maior dos municipios. Apesar da grande adesão e do amplo apoio que recebe de diversos autores que pertencem ao campo do movimento sanitário, o PSF também recebe críticas, não se constituindo uma unanimidade. Autores como FRANCO e MERHY ${ }^{50}$ (2000) tem se referido a "contradições de um programa destinado à mudança do modelo assistencial" e fundamentam essas contradições nos seguintes aspectos: 
O PSF tem como foco principal da estratégia de mudança do modelo a utilização de tecnologias de planejamento para intervir em um determinado território visando atuar nas variáveis que se relacionam ao adoecimento da população. Nesse "território-processo" - conceito difundido pela OPAS que abrange território social, econômico, político, epidemiológico - as intervenções propostas tem como principais instrumentos a epidemiologia e a vigilância à saúde. Essa proposta de intervenção valoriza ações sobre o território em questão utilizando conceitos de "áreas de abrangéncia" e "micro-áreas de risco" - delimitações geográficas que procuram caracterizar um perfil homogêneo de "riscos de adoecer" baseado nas condições sócioeconômicas - e situações de risco dos diferentes grupos populacionais

Esses autores consideram que essa estratégia tem limitações pois "não dá muito valor ao conjunto da prática clínica, nem toma como desafio a necessidade de sua ampliação na abordagem individual nela contıda ..." (p.21). Dessa forma ao não "cuidar da clinica o PSF não entra no terreno da competência da corporação médica, ficando no âmbito da saúde coletiva e age como linha auxiliar do Modelo Médico Hegemônico".

Retornaremos, mais à frente neste capitulo, quando nos referirmos aos desafios da nova agenda da descentralização, a essa polêmica entre os que apoiam e os que questionam as possibilidades do PSF como estratégia estruturante de inversão do modelo assistencial.

Entre os experimentos que também visam inverter o modelo assistencial, merece destaque as propostas de acolhimento, responsabilização e vínculo (FRANCO e col. ${ }^{49}, 1999$ e FRANCO e MERHY ${ }^{50}, 2000$ ), que tem sido compreendida como estratégias direcionadas á intervir nos microprocessos de trabalho da unidade, na relação dos usuários com os trabalhadores de saúde e na capacidade efetiva de absorver a demanda e resolver os problemas de saúde. A operacionalização dessa proposta obedece os seguintes principios: 
(1) Atender a todas as pessoas que procuram os serviços de saúde, garantindo a acessibilidade universal (...);

(2) Reorganizar o processo de trabalho, a fim de que se desloque seu eixo central do médico para a equipe multiprofissional (denominada) equipe de acolhimento (...);

(3) Qualificar a relação trabalhador-usuário, que deve desenvolver-se segundo princípios humanitários de solidariedade e cidadania" (p. 347)

Estudo de caso - realizado em Betim-MG - sobre o impacto dessa proposta de acolhimento mostrou que houve: (1) melhora na acessibilidade, com aumento significativo da média de atendimentos/mês; (2) aumento no rendimento (produtividade no trabalho) de todos os profissionais, mas especialmente do profissional não-médico - enfermeiro e assistente social, e (3) aumento na resolubilidade, em virtude de solução mais freqüente dos problemas dos usuários pela equipe. Entre os problemas encontrados, o mais expressivo foi a fraca adesão dos profissionais médicos à proposta.

É necessário registrar que a proposta de acolhimento surgiu inicialmente em Belo Horizonte-MG para organizar a assistência médica de pronto-atendimento em pediatria e, posteriormente, passou a ser aplicada também nas outras áreas de assistência nas UBS. Em nossa opinião ela constitui uma forma aperfeiçoada de triagem e seus beneficios à população usuária serão maiores se aplicar adequadamente protocolos clínicos de conduta - ampliando, por exemplo, o papel assistencial dos profissionais não-médicos e referenciando adequadamente os pacientes para os niveis mais complexos de atenção - com bom-senso e solidariedade ao usuário.

Retornando ao nosso estudo de caso, a investigação empírica permite algumas inferências a respeito das dificuldades de mudança do modelo assistencial. O municipio de Marília, no último periodo analisado - de 1997 a 1999 - optou por adotar duas estratégias de inversão do modelo 
assistencial: (1) a "estratégia de saúde da familia" em algumas regiões da cidade e (2) a "distritalização sanitária" através do estudo da realidade epidemiológico/sanitária local - "cartas sanitárias" - associado ao planejamento em UBS com a participação dos CLS, utilizando variante do método MAPP - Método Altadir de Planejamento Popular (MATUS ${ }^{76} 1996$, p. 36).

Que resultados vêm apresentando essas estratégias em Marilia?

Nosso estudo não teve como objetivo avaliar os resultados de projetos particularizados, mas o de avaliar essas politicas em suas diretrizes e na perspectiva de exercerem impacto sobre as mudanças das práticas sanitárias. O Programa de Saúde da Familia foi implantado em algumas regiōes da cidade. Existe a intenção de ampliá-lo, mas não para todo o munıcipio. A outra atividade - distritalização sanitária - aparentemente não está tendo a continuidade desejada. Ou seja, além do desinteresse em utilizar o PSF, ao menos até o período em que isso foi analisado - final de 1999 - como a principal estratégia estruturante na construção de novo modelo de saúde, foi possivel perceber o sentimento de pouco entusiasmo com os potenciais resultados da descentralização do planejamento para as UBS.

Os gestores locais sabem da importância de implementar atividades estruturantes que tenham impacto na mudança do modelo assistencial. Eles têm, porém, clareza dos inúmeros obstáculos que essas medidas encontram para consolidar novas práticas sanitárias além das práticas curativoindividuais.

Os obstáculos mais perceptiveis, já citados em outras partes deste estudo, situam-se em distintas dimensões: no perfil dos recursos humanos que atuam na rede de saúde, na cultura prevalecente em usuários/comunidade, hegemonicamente ligada ao modelo tradicional, e na 
cultura das organizações que resistem a mudanças. Além disso, as "demandas do cotidiano" - o eterno apagar de incêndios com o qual os gestores têm que conviver - reduzem a consistência do planejamento desses modelos alternativos. Os projetos de mudança nem sempre têm a continuidade desejável, como foi o caso do planejamento descentralizado nas UBS.

Percebe-se claramente a dificuldade de integração efetiva entre as atividades preventivas e as curativas, apesar das mesmas, diferentemente do periodo pré-SUS, ocorrerem no mesmo local - a Unidade Básica de Saúde. A integralidade, com a uniāo dos diferentes campos de atenção prevenção, cura, promoção e reabilitação - continua sendo uma imagemobjetivo que não se consubstancia, concretamente, na prática.

No que refere aos niveis mais complexos da assistência - nas áreas especializada e hospitalar - percebemos mais entusiasmo dos gestores do último período - 1997 a 1999 - com as medidas que estão sendo implementadas após o advento da gestão plena do sistema municipal. Esses gestores conseguiram modificar, ao menos em parte, as relações contratuais e conveniais que existiam até esse periodo com os prestadores de serviço, tornando-as mais condizentes com os interesses do SUS. Consubstanciaram-se em parcerias e modificações de modelo, tais como: centralização da "porta de entrada" na atenção de urgência/emergência, internação domiciliar etc. Nessa área de assistência, no entanto, pelo fato da oferta ser predominantemente privada e de existirem lacunas assistenciais em alguns niveis de complexidade, especialmente na média complexidade, foi possivel identificar limites para a ação do poder local. Esses limites especialmente para alterar de maneira efetiva as formas de remuneração e incorporar novos serviços privados para atender as necessidades do sistema - dificultaram a reorganização da oferta. 
Consideramos, em síntese, no que se refere à atenção básica, que o estudo de caso confirmou parcialmente o pressuposto 4 . Os gestores locais reconheceram a importância de substituir o modelo assistencial tradicional, que se encontrava "esgotado" e convivendo com elevada demanda reprimida e problemas gerenciais que comprometiam sua qualidade, porém os caminhos que poderiam ser utilizados para isso aparentemente não estavam suficientemente claros. Nos níveis mais complexos da assistência, ao contrário, os gestores se mostraram mais seguros na explicitação e na implementação das diretrizes de mudança. É importante destacar, no entanto, que em ambas as situações, tratando-se da atenção básica ou dos niveis mais complexos a reorganização da oferta assistencial para a atenção individual está tolnıda pela baixa governança local.

Esses achados nos levam a concluir que as diretrizes para mudança do modelo assistencial estavam mais claras quando se referiam a organizar a assistência aos "danos à saúde" - aqui entendidos como atenção curativa - pois dizem respeito a demanda individual nas áreas básica, especializada e hospitalar, e visavam reorganizar a oferta para adequa-la às necessidades. A implementação dessas diretrizes foi parcial, pois constrangimentos especialmente os ligados ao financiamento - que ultrapassam os limites de solução pelo poder local impediam o equacionamento de todos os problemas.

Quando se tratava, no entanto, de organizar o modelo para intervenções nos "riscos à saúde" - aqui entendidos como intervenções em fatores de risco, situações de risco e implementação da vigilância à saúde ou nas determinantes do processo saúde/doença - aqui entendidas como fatores ligados a condições de vida -, os gestores não tinham clareza de que diretrizes implementar. Nesse caso, em nosso ponto de vista, as dificuldades se explicam por dois fatores. O primeiro diz respeito à presença de constrangimentos de caráter nitidamente estrutural, especialmente os que dizem respeito a aspectos redistributivos, conforme já abordamos 
anteriormente. O outro refere-se à dificuldade de integrar estratégias de reorganização da atenção clinica individual - por si só tolhidas pela pouca governança dos gestores locais - com as ações preventivas e de promoção da saúde.

\subsection{Os desafios para a nova agenda da descentralização da saúde}

Vislumbram-se indícios de significativas mudanças na agenda da descentralização da saúde no país. A principal proposta, já em fase de implementação, é a "Regionalização de Assistência à Saúde". Essa proposta, consubstanciada na NOAS SUS 01/2001, já abordada no capitulo 1, também conhecida como "microrregionalização" e "organização de sistemas funcionais de saúde", tem como justificativa o propósito de superar dificuldades do processo de descentralização, entre as quais sobressaem as seguintes

(1) alocação de serviços ainda fortemente vinculada à lógica de oferta de serviços e não a necessidades epidemiológicas;

(2) ampliação desordenada da capacidade instalada pública e da incorporação de serviços privados ao SUS, impedindo a criação de rede regionalizada e resolutiva, mantendo-se um modelo de ações superpostas, sem organização do acesso e fluxo de pacientes, especialmente de alta complexidade;

(3) falta de integração entre as diversas politicas de descentralização.

A Regionalização da Saúde prevê reorganização do fluxo de pacientes entre os diversos niveis de atenção e, especialmente, entre diferentes municipios, e melhoria do acesso, ao definir com mais clareza a responsabilidade pela assistência.

É nesse contexto de readequação da agenda da descentralização da saúde que vamos apresentar as conclusões deste estudo. Consideramos que algumas das informações obtidas com a presente investigação podem 
somar-se às contribuições que tem como objetivo o aperfeiçoamento desse processo. Essas contribuições para os desafios da nova agenda da descentralização da saúde, a nosso ver, situam-se em diferentes campos e serão analisadas a seguir:

\section{a) RECURSOS HUMANOS}

Esta área ıem sido considerada um dos principais pontos de estrangulamento do SUS. O CONASEMS (Jornal do CONASEMS ${ }^{57}, 2000$ ), por exemplo, sistematicamente tem se referido às preocupações dos secretários municipais de saúde com esse tema., considerada "prioridade máxima (...) e um dos principais problemas do SUS atualmente". Para o CONASEMS, um ponto fundamental da agenda da descentralização é a política de recursos humanos.

Em nosso ponto de vista a preocupação com a inexistência de uma política de recursos humanos para o SUS se justifica tanto por seus aspectos qualitativos, de capacitação e preparo dos profissionais de saúde para o exercicio das diferentes atividades necessárias para a continuidade de implementação do SUS, quanto pela quantidade de profissionais que está sendo disponibilizada para o sistema tendo em vista a presente forma de organização dos serviços.

A inserção de novos profissionais de saúde no SUS, mesmo tendo sido crescente nas duas últimas décadas, tem sido, ultimamente, constrangida por fatores conjunturais e estruturais que poderão ter forte repercussão negativa na agenda futura do SUS. Com a transferência de unidades assistenciais dos niveis mais centrais para os mais periféricos de governo - por exemplo, transferência dos antigos PAMs do INAMPS para as Secretarias Estaduais, ou de centros de saúde estaduais para os municipios -,que ocorreu com o processo de descentralização, os servidores que atuavam nessas unidades também foram transferidos. Sua reposição, no 
entanto,- em decorrência de aposentadorias, exonerações ou afastamentos por outros motivos - não ocorreu, ficando esse encargo para o nivel de governo que assumiu as unidades descentralizadas

Essa situação ampliou significativamente o quadro de servidores ativos dos municípios porque, além de assumir as responsabilidades impostas pela transferência de serviços, esse nivel de governo passou a ser responsável por manter toda a estrutura de recursos humanos que atua nas redes básicas de saúde. Com o esgotamento da capacidade de expansão do quadro de pessoal, em decorrência da falta de recursos financeiros e das dificuldades impostas pela legislação - tais como a Lei de Responsabilidade Fiscal - os municipios estão tendo dificuldades em ampliar a oferta de serviços para atender lacunas na assistência.

É necessário que se regulamente uma legislação compativel com o contexto da descentralização da saúde e que contribua para superar esses obstáculos e, além disso, que os municipios sejam apoiados solidariamente pelos outros niveis de governo no financiamento da saúde, para enfrentar as dificuldades nessa área.

Além desses, outros aspectos quantitativos da estrutura de recursos humanos para o SUS devem ser enfrentados com políticas públicas consistentes. Não é propósito deste estudo aprofundar-se neste tema, sobre o qual existem diversas publicações e análises consistentes, mas apenas destacar que a falta de profissionais adequados se devem, muitas vezes, não só à concentração inadequada dos mesmos nos grandes centros urbanos, mas também ao número insuficiente de profissionais de saúde, em algumas áreas especializadas, para atender às necessidades do país.

Com respeito aos aspectos qualitativos, a formação, capacitação e educação continuada são temas de inquestionável importância e mais apropriados de serem tratados em estudos especificos. Ressaltamos, a 


\section{GESTORES}

A capacitação de recursos humanos e, em especial, de gestores municipais, é indispensável para o aperfeiçoamento da descentralização. Ficou bem evidenciada, no estudo de caso, a importância desses personagens na implementação das mudanças. Gestores com as caracteristicas desejáveis nem sempre estão presentes nas arenas locais. Suas presenças nessas arenas, com possibilidade efetiva de articular estratégias factiveis e viáveis coerentes com a reforma da saúde, transformando-se em verdadeiros "sujeitos de mudança", é fundamental para a o êxito da municipalização da saúde.

Os cursos de capacitação de gestores municipais que estão sendo promovidos por instituições de ensino na área de saúde pública - entre as quais citamos como exemplo a Faculdade da Saúde Pública da USP e a Escola Nacional de Saúde Pública (ENSP) da Fundação Instituto Oswaldo Cruz (Fiocruz) - têm grande importância no aperfeiçoamento da descentralização. Seria desejável, no entanto, que a essas iniciativas se somassem ações mais ousadas dos governos estaduais e do Ministério da Saúde. Essas atividades de capacitação de gestores deveriam contemplar mais intensamente algumas áreas de formação que são especialmente úteis no desafio das gestões municipalizadas, tais como: (1) Estado, sociedade e políticas públicas; (2) administração, planejamento e estratégia; (3) economia da saúde; (4) liderança e mudanças; (5) teoria de organizações Entre essas áreas de formação, uma destaca-se como tendo importância particular: a capacitação de lideranças pois, como registrou este estudo, a atuação de lideres com conhecimento técnico, capacidade de articulação politica e vontade de mudar foi imprescindivel para o sucesso na implementação das políticas locais de saúde. 


\section{EQUIPES DE PSF}

$O$ perfil nem sempre adequado dos profissionais que atuam nas equipes de Saúde da Familia tem dificultado muito as mudanças das práticas sanitárias e do modelo assistencial. Esse "nó crítico" tão ressaltado nos diferentes fóruns de discussão e avaliação da implantação do SUS continua um desafio em aberto. A revisão da formação profissional, a capacitação e a educação continuada desses profissionais necessitam de planejamento mais consistente que analise a viabilidade dessas operações e estabeleça metas de curto, médio e longo prazo

\section{b) APERFEIÇOAMENTO DA DEMOCRATIZAÇĀO DO PROCESSO DECISÓRIO}

O deslocamento de poder propiciado pela municipalização da saúde não está garantindo, com a qualidade necessária, a democratização das decisões e o controle social. A institucionalização dos conselhos de saúde está sendo um passo à frente nesse sentido. Esses canais de participação, no entanto, têm sua influência limitada por diversos fatores. Alguns deles, já abordados ao longo deste estudo, dizem respeito aos limites do chamado poder local Ou seja, os conselhos podem tomar algumas decisōes que estão dentro de seu espaço de poder - ou de sua governabilidade -, porém muitos problemas que atingem os usuários só poderão ser enfrentados com politicas públicas conduzidas e implementadas por um Estado mais democrático e respeitador dos direitos do cidadão. Outros fatores dizem respeito ao micropoder que existe no interior das organizações de saúde. Ou seja, procurando explicar de outra forma, os conselhos municipais e locais de saúde encontram, por um lado, obstáculos que ultrapassam os seus limites de poder e que se processam em arenas politicas situadas fora dos limites do poder local e, por outro lado, não estão atuando nas distintas arenas que compõem as organizaçōes de saúde, dentro dos seus espaços concretos de intervenção. 
$\dot{E}$ necessário aperfeiçoamento dos canais institucionais de participação - conselhos e conferências de saúde - já que muitos desses fóruns ainda são verdadeiras participações do "faz-de-conta", sendo também indispensável que o controle social atinja as esferas de poder existentes no interior das organizações de saúde, atualmente inacessiveis ao controle público.

Operacionaimente, essas mudanças poderão dar-se promovendo mudanças nos modelos de gestāo das unidades de saúde e com nova institucionalização dos conselhos gestores de unidades. CECíliO ${ }^{* x}$ (1999, p. 34-35) chama a atenção para esse assunto, de cuja posição ressalto os seguintes aspectos:

(1) a importância de implementar modelos de gestão participativa nas unidades de saúde, com criação de mecanismos colegiados de decisão, associado a estabelecimento de missão e objetivos organizacionais claramente definidos:

(2) a incorporação de conselhos gestores de usuários ao processo de gestão da unidade, criando condições para que o controle social seja exercido na concretude de missão, objetivos e metas.

Consideramos que controle social mais efetivo só será possivel se conseguirmos pactuar "contratos de gestão" entre a população usuária e os serviços de saúde, reconhecendo os distintos interesses que coexistem nas organizações de saúde, e, ao mesmo tempo, estabelecendo parâmetros prioritários que interessem ao público que se utiliza dos serviços. $\dot{E}$ preciso respeitar esses interesses, quando legitimos, mas simultaneamente, nos pactos estabelecidos, submetê-los aos interesses do SUS. Isso só será possivel se houver maior inserção dos usuários dentro das organizações onde esses interesses se manifestam. 
c) GARANTIA DA DIRECIONALIDADE E DA CONTINUIDADE DO PROCESSO DE MUDANÇAS

É natural que a alternância de poder nos governos locais ocasione reorientações do projeto de governo para a área da saúde. $O$ incipiente processo democrático brasileiro, no entanto, tem particularidades que mostram que a alternância politica não se processa com alternância de projetos. Na maijria das vezes por sinal, e isso foi observado em nosso estudo de caso, os governantes locais nem sequer conseguem esboçar um projeto consistente de governo ou projetos setoriais suficientemente claros que possam ter impacto na forma de governar e de exercer o poder.

\section{Como enfrentar essa questão?}

Infelizmente é muito difícil superar totalmente esses problemas. $\dot{E}$ necessário tentar evitar, no entanto, que governantes opositores, quando assumem o poder, interrompam projetos inovadores e bem-sucedidos, fazendo a política da chamada "terra arrasada", apenas porque foram implantados pela administração anterior.

Muitas vezes os projetos não são formalmente interrompidos mas as mudanças que estavam em curso não tem continuidade. Uma gestão bem sucedida é interrompida ao não ter sua direcionalidade mantida. Os novos gestores não tem a mesma percepção ou os mesmos interesses dos gestores que saíram e imprimem um novo "projeto", em outra direção, interrompendo um processo de mudanças que poderia trazer bons resultados no futuro.

Como impedir que isso ocorra?

Trata-se de um desafio dificil de ser superado, pois a institucionalização de um processo de mudanças depende de fatores 
diversos, tais como grau de aceitação e satisfação do usuário e cultura política dos governantes, entre outros.

É necessário que no âmbito do poder local a institucionalidade dos projetos de mudança coerentes com os princípios do SUS seja ampliada, envolvendo outras arenas de poder além do executivo. A homologação das decisões do Conselho Municipal de Saúde, logo após terem sido tomadas, e a realização de audiências públicas no espaço do legislativo, são exemplos de medidas recomendadas pelas normas do SUS e raramente cumpridas

\section{d) CUSTO/EFETIVIDADE}

A otimização na utilização dos recursos e a criação de mecanismos de escala que possibilitem melhorar a eficiência econômica em saúde é outro desafio da nova agenda. O custo/beneficio no SUS não deve ser analisado de forma desvinculada da eficácia social das ações desenvolvidas, sendo, por esse motivo, mais conveniente tratar esse tema como custo/efetividade, que no atual contexto significa relação entre recursos empregados e impacto obtido na população-alvo.

Esse tema tem sido tratado de diversas formas. MENDES ${ }^{\times 2}$ (1998, p.57), por exemplo, considera que a adequada gestão na saúde deve atingir os seguintes objetivos: eqüidade, eficácia, eficiência, qualidade e satisfação dos usuários. As propostas apresentadas por esse autor, "destinadas a aumentar a eficiência e a qualidade da atenção e satisfação dos usuários" (p. 64) têm como estratégia a promoção da "reengenharia dos sistemas de serviços de saúde", na qual são componentes de destaque a preocupação com a economia de escala nos serviços mais complexos e a adequada utilização da tecnologia.

No estudo da municipalização de Marilia não foram investigados assuntos ligados à economia da saúde. Foi possivel perceber, porém, que 
os mecanismos de integração entre o municipio-polo - Marília - e os municipios da região têm falhas não supridas pela Programação Pactuada e Integrada (PPI), que, na prática, ainda funciona muito mal.

A nova agenda da descentralização que se vislumbra, aperfeiçoando a regionalização, descrita no início deste tópico, tem como um dos objetivos suprir essas falhas. Reconhecemos como necessárias essas mudanças. Destacamos, porém, que é fundamental que seja preservada a autonomia politica e administrativa própria do pacto federativo brasileiro. A nãopreservação dessa autonomia poderá interromper o processo de democratização das decisões e o aperfeiçoamento da gestāo do sistema de saúde, que, apesar dos percalços, encontram-se em curso.

Em nosso entendimento essas mudanças devem ter objetivos claros: (1) otimizar a utilização dos recursos de abrangência regional; (2) criar mecanismos de escala que ampliem a eficiência econômica, e (3) promover a eqüidade locorregional.

A nova agenda da descentralização poderá contribuir, se o processo for bem conduzido, para ampliar a cooperação da União e dos governos estaduais e municipais entre si, otimizar os serviços de maior densidade tecnológica e criar instâncias intermunicipais (regionais) de planejamento participativo.

e) MODELO ASSISTENCIAL

Devemos reconhecer as dificuldades de mudança de modelo assistencial que as atividades estruturantes do SUS têm encontrado, como analisado no item 5.3. As estratégias utilizadas, quando não são associadas à intervenção nos microprocessos da gestão da saúde, têm pouco impacto na mudança do modelo, como ficou evidenciado em nosso estudo de caso e como já mencionamos anteriormente. 
Com o crescimento do PSF vislumbra-se a agudização de uma polêmica, especialmente nas instâncias acadêmicas e nas discussões entre gestores, sobre se esta proposta é a melhor alternativa para a estruturação de um novo modelo assistencial.

Em nosso ponto de vista, devemos ter o cuidado de não adotar, dogmaticamente, つ PSF como o único modelo de inversão do modelo assistencial. Além disso é conveniente flexibilizá-lo na sua aplicaçāo quando isso for conveniente nos contextos local e regional e incentivar outros modelos tecno-assistenciais que partilhem do mesmo ideárı de :...danças. Esse ideário pode ser traduzido, em nosso ponto de vis:a :.. alguns conceitos e objetivos, tais como: (1) vinculação da equipe de aterıấ básica a um determinado território onde exista um contingente compativel de usuários à capacidade de trabalho da equipe; (2) responsabilzação da equipe pela promoção da saúde e pela oferta e referenciamento de atividades assistenciais adequadas à população adstrita - inciuindo os diferentes campos de atenção: prevenção, cura, reabilitação e promoção e (3) incorporação dos usuários como sujeitos coletivo e individual das ações de saúde, considerando que as mudanças não devem ser feltas para eles mas com eles.

Os desafios de reorganização da atenção básica são tão amplos que diferentes estratégias e tecnologias podem ser incorporadas ao modelo de saúde desde que apropriadas para alcançar os objetivos acima. Não vemos incoerência entre implementação da proposta de acolhimento, padronização de protocolos de conduta clínica, gestāo de cuidados etc., com vinculação e responsabilização desde que estejam inseridas em uma mesma lógica de gestão e se constituam em estratégias articuladas entre si

Em cidades de maior porte, que normalmente têm uma rede consolidada e com forte inserção de profissionais médicos especializados 
das áreas básicas - pediatras, ginecologistas e clínicos - e também, em algumas situações, contam com serviços de internação domiciliar, serviços inovadores na área de saúde mental, serviços de acompanhamento de diferentes grupos de risco - tais como lactentes, gestantes etc. -, não devemos simplesmente substituir essas tecnologias mas integrá-las com outras propostas e modelos que permitam avançar no processo de mudanças.

Como disse o poeta japonês Matsuo Bashô, aliás citado em texto de avaliação da estratégia de saúde da familia em meados da década de 1990 publicado pelo Ministério da Saúde. "Não façam o que eles fizeram. Antes, procurem o que eles procuravam". Não exıstem fórmulas prontas para inversāo do modelo assistencial em saude. Algum grau de pluralismo na implementação das estratégias e a preservação de autonomia para os gestores locais utilizarem as medidas mais pertinentes e adequadas ao contexto local são aconselháveis.

Como regra geral algumas sugestóes que se aplicam a qualquer realidade, desde que submetidas às necessárias adaptações, são resumidas nos itens que se seguem:

(1) modificar o funcionamento dos centros de saúde tradicionais incorporando ou não equipes de saúde da familia -, mantendo estes equipamentos públicos como bases operacionais - planejamento e atendimento à demanda - das equipes. Essas equipes atuariam na unidade e fora dela, realizando, por exemplo, monitoramento de situações, grupos e individuos de risco, assistência e internação domiciliar;

(2) as equipes locais deverão ser estimuladas a estruturar um sistema de informações em saúde que, integrado ao sistema geral de informações do municipio, Ihes permita analisar e monitorar permanentemente a situação de saúde de sua área adstrita.

(3) as equipes locais e os representantes da comunidade estabelecerão sua missão institucional e os objetivos e metas no processo de planejamento descentralizado e participativo; 
(4) esse reordenamento das práticas sanitárias na área de atenção básica deverá procurar superar alguns obstáculos comuns a um processo de mudanças dessa natureza, tais como dificuldades de trabalho em grupo e falta de dominio de instrumentos e técnicas necessários, entre outros, os governantes locais da saúde terão o papel de disponibilizar os instrumentos e apoiar o processo;

(5) é necessário diferenciar dois niveis distintos de problemas que deverão ser enfrentados: o primeiro diz respeito à substituição do modelo de saúde caracteristico dos centros de saúde tradicionais - centrados na atenção médica e em programas de saúde - por nova estruturação do processo de trabalho que tenha como paradigma a vigilância à saúde e a reorganização da oferta assistencial nos diferentes niveis de atenção da população da área. Devemos valorizar e aproveitar as experiéncias bem sucedidas e os esforços desenvolvidos pelas equipes dos ceriros de saúde para melhorar a qualidade da assistência, construindo u, eles e não para eles - esse novo modelo ; o segundo diz respelto a relação da equipe entre si e com os usuários, tendo como paradigma a solidariedade com o outro, o respeito à vida e a revisão e a substıtuição de conceitos arraigados na cultura dos profissionais, da população e das organizações de saúde;

(6) desafio especifico desse processo de mudanças refere-se à pactuação dos diversos interesses corporativos presentes nas equipes de saúde com os interesses do SUS; nesse tema o profissiona médico desempenha papel especial pelo poder de que dispōe no modelo hegemónico. Como propõe CECíliO (1999), é necessário integrar o profissional médico com os objetivos da organizaçāo e. para isso, protocolos de cuidados clínicos, componentes da lógica corporativa, devem-se submeter a regras e normas que seguem os principios e a doutrina do SUS

(7) Nas áreas de mais flagrante exclusāo social, tais como regıbes de favelas e subhabitaçōes, deve-se procurar integrar a implementação da estratégia de saúde da familia com outras políticas de governo - nas áreas de educação, assistência social, meio ambiente, infra-estrutura urbana, geração de empregos, etc. - visando a "integração das politicas de inclusão social".

(8) Nos niveis de complexidade maiores devem-se adotar estratégias que possibilitem repactuar a relação contratual e convenial com os prestadores de serviço e com municipios de referência. As propostas que estão atualmente em discussão sobre a regionalização da saúde, já referidas, se bem aplicadas podem contribuir na implementação dessas estratégias. 
Para finalizar, é necessário reconhecer a estreita relação que əxiste entre a ação política local, a cargo de gestores comprometidos com a transformação dos sistemas de saúde em seus espaços concretos de atuação, e a ação politica mais geral, que procura democratizar as relações entre a sociedade e o Estado. No local, da forma como foi considerado neste estudo, existem inúmeros desafios a superar para melhorar a qualidade na atenção à saúde. Os limites para a sua transformação, no entanto, associam essa ação transformadora aos outros niveis de poder

A articulação entre o local e o geral e um dos desafios do Movimento Sanitário para a consolidação de sua identidade no atual contexto de implantação da Reforma Sanitária. A democratızação do processo decisório e a redução das desigualdades sociais, fatores indissociáveis da reforma da saúde, estão intrinsecamente ligados à eficiência e eficácia na gestão da saúde. É necessário recuperar essa dimensão mais ampliada da Reforma para não limitar nossa ação transformadora a medidas gerenciais inovadoras desvinculadas do contexto político em que elas são implementadas.

A estratégia politica dos que procuram reformar a saúde deve considerar dois diferentes campos, igualmente importantes, para a ação política: o campo singular, onde se deve dar o aperfeiçoamento da gestão dos sistemas de saúde, e o outro, mais amplo, onde a agenda prioritária é constituida pela superação de obstáculos estruturais que dificultam as mudanças. Esses elementos têm como pressuposto o reconhecimento de que os obstáculos de caráter estrutural - decorrentes de determinantes socioeconômicas e seus reflexos sobre as condições de vida e saúde remetem a reforma da saúde à luta pela reforma do Estado em busca de lıma sociedade mais justa

Nesse, sentido é necessário reconhecer a fragilidade das bases politicas que dão sustentação à Reforma Sanitária brasileira. A ampliação 
das forças políticas que tentam assegurar a continuidade de mudanças que restabeleçam o direito à saúde só será possivel com a permarente articulação do Movimento Sanitário. 


\subsection{Considerações finais}

Para finalizar, podemos concluir que este estudo de sujeitos, atores e políticas envolvidos com o processo de municipalização da saúde suscita diversos temas para reflexão, resumidas a seguir:

1. A municipalização permite, dentro dos limites do poder local, que sejam colocadas em prática ações de saúde inovadoras que tenham como objetivo a eqüidade em saúde e o desenvolvimento de práticas intersetoriais;

2. A consolidação de modelos de saúde alternativos, resultantes de experiências municipais que adotam o paradigma do SUS em situações favoráveis como as descritas no tópico anterior, enfrenta três niveis distintos de dificuldades: (1) estruturais, de caráter socioeconômico, que se refletem nas condições de saúde dos usuários; (2) de oferta inadequada e de desorganização na utilizaçăo dos serviços assistenciais, especialmente os de média e alta complexidade; e (3) ligadas aos aspectos mais particularizados da relação entre usuários, trabalhadores e serviços de saúde;

3. Enquanto, no pacto federativo brasileiro, o primeiro nivel relaciona-se com aspectos macroeconômicos e o segundo com a suficiência de recursos e a organização dos fluxos de atendimento, o terceiro está mais claramente situado nos limites de ação do poder local;

4. Existem diferentes instâncias - federal, estaduais e municipais - de formulação e implementação de politicas e estratégias que tem como objetivo superar o segundo e terceiro niveis de dificuldades, citados acima; neste trabalho preocupou-nos estudar a instância municipal, no transcorrer do processo de municipalização da saúde, 
5. A municipalização contribui para a democratização da gestão da caúde; os mecanismos de prestação de contas e de transparência na aplicação de recursos públicos são aperfeiçoados com a institucionalização de canais de participação direta da sociedade;

6. A interferência no processo decisório, no entanto, só terá impacto na qualidade dos serviços se forem construidas novas relações entre os dirigentes das organizações, os trabalhadores de saúde e os usuários esse "pacto de gestão" poderia contribuir para que a missão social das organizações de saúde fosse gradativamente viabilizada;

7. Além disso, a articulação das diferentes politicas e estratégı́s nos municipios - espaços concretos em que se efetivam as mudanças das práticas sanitárias - depende de "sujeitos de mudança"; esse núcleo de mudanças deve ser coordenado pelos gestores locais que devem es:ar capacitados e motivados para isso, e esses gestores estarão preparados para exercer a liderança necessária nesse processo desde que possuam algumas caracteristicas, entre as quais destacam-se a responsabilidade. a credibilidade, a capacidade para a condução da politica e o comportamento ético;

8. Além da democratização do processo decisório e da presença, nas arenas de decisão, de gestores com perfil adequado para liderar e conduzir as mudanças, também é necessário que as diversas estratégras e experiências, cuja finalidade é estruturar os sistemas locais de saúde, tenham factibilidade e viabilidade. Atividades estruturantes que se hegemonizam na "cultura da Reforma Sanitária" e que, muitas vezes, constróem sua viabilidade politica e se transformam em ações institucionais oficiais nem sempre são factiveis; transformam-se rapidamente em modismos, caem no esquecimento e são substituidas por outras; 
Alguns desses temas apontam para a necessidade de reflexão mais aprofundada em estudos futuros, constituindo tópicos para novos estudos acadêmicos. Outros, em nosso ponto de vista, constituem tópicos a serem incorporados na agenda da descentralização da saúde, e colocados em prática pelos administradores da saúde. 


\section{REFERÊNCIAS BIBLIOGRÁFICAS}

1. Almeida ES, Castro CGJ, Lisboa CA. Distritos sanitários: concepção e organização. São Paulo: Faculdade de Saúde Pública da Universidade de São Paulo; 1998. (Série Saúde \& Cidadania).

2. Bardin L. Análise de conteưdo Lisboa: Edições 70; 1995

3. Bittar OJNV. Hospital, qualidade e produtividade. São Paulo Sarvier; 1997

4. Bobbio N. Qual socialismo? Discussão de uma alternativa Rio de Janeiro: Paz e Terra; 1983.

5. Bobbio N Politica, In Bobbio $N$, Matteuci $N$ Pasquino $G$ Dicionário de Politica $2^{a}$ ed. Brasilia Editora Universidade de Brasilia; 1986. p.329-335.

6. Bobbio N Estado, governo, sociedade: por uma teoria geral da politica $7^{\text {a }}$ ed. Rio de Janeiro: Paz e Terra; 1999.

7. Bowman $M$, Hampton W. Democracias locales: un estudio comparativo. México: Fondo de Cultura Económica; 1989.

8. Brasil. Ministério da Saúde. Municipalização das açōes e serviços de saúde: a ousadia de cumprir e fazer cumprir a lei. Saúde em Debate $1993 ; 38$ (mar):4-17.

9. Brasil. Ministério da Saúde. Portaria 545, de 20.05.93: estabelece normas e procedimentos reguladores do processo de descentralização das açōes e serviços de saüde e aprova a NOB 01/93. Diário Oficial da União, Brasilia, 20 mai 1993

10. Brasil. Ministério da Saúde. Plano diretor da reforma do aparelho do Estado Brasilia: Ministério da Administraçāo Federal e da Reforma do Aparelho do Estado. 1995.

11. Brasil. Ministério da Saúde. Portaria 2.203, de 06.11.96: redefine o modelo de gestão do Sistema Único de Saúde e aprova a NOB 01/96. Diário Oficial da Uniāo, Brasilia, 06 nov 1996.

12. Brasil. Ministério da Saúde. Secretaria de Assistência à Saúde Coordenação de Saúde da Comunidade. Saúde da Familia: uma estratégia para a reorientação do modelo assistencial Brasilia. Ministério da Saúde, 1997. 
13. Brasil Ministério da Saúde. Portaria 1.329, de 12.11.99: estabelece nova sistemática para o cálculo do incentivo financeiro ao programa de saúde da familia, parte integrante do piso de atenção básica PAB. Diário Oficial da União, Brasilia, 12 nov 1999.

14. Brasil. Presidência da República. Lei n.101, de 05 de maio de 2000 estabelece normas de finanças públicas voltadas para a responsabilidade na gestão fiscal e dá outras providências. Diário Oficial da União, Brasilia, 05 mai 2000.

15. Brasil. Ministério da Saúde. Situação atual do processo de habilitação. Disponivel em <http //umw saúde gov br/descen/habilita htm/>. [2.000 Set 16].

16. Brasil. Ministério da Saúde A descentralização do sistema de saúde no Brasil. Uma proposta de investigação sobre o impacto de politicas Junho de 1998 Disponivel em <http //mun datasus gov.br/cns>. [2.000 Set 18].

17. Brasil. Ministério da Saúde. PACS/PSF. Onde estamos? Disponivel em <http://mwn gov br>. [2.000 Set 20]

18. Brasil. Ministério da Saúde. Portaria 95, de 26.01.01: aprova a NOAS-SUS 01/2001. Diário Oficial da União, Brasilia, 26 jan 2001

19. Bueno WS, Merhy EE. Os equivocos da NOB 96: uma proposta em sintonia com os projetos neoliberalizantes? Disponivel em $<$ http://muw. datasus.gov.br/cns>. [1998 Out 13].

20. Campos GWS. Um balanço do processo de municipalização dos serviços de saúde no Brasil. Saúde em Debate 1990, 28: 24-27.

21. Campos GWS. Análise critica das contribuiçōes da Saúde Coletiva à Organização das práticas de saúde no SUS. In: Teixeira SMF, organizadora. Saúde e democracia. A luta do Cebes. São Paulo: Lemos; 1997 . p. 113-124.

22. Carvalho Al. Conselhos de Saúde no Brasil: participação cidadã e controle social. Rio de Janeiro: Fase/lbam; 1994.

23. Carvalho Al Conselhos de Saúde, responsabilidade pública e cidadania: a reforma sanitária como reforma do Estado. In: Fleury S, organizador. Saúde e democracia: a luta do CEBES. São Paulo Lemos; 1997. p.93-111. 
24. Carvalho AM. A Pesquisa no debate contemporâneo e o Serviço Social. Cadernos ABESS 1995; 5: 43-66.

25. Carvalho SN, Costa V. Politicas públicas, tomada de decisões e formação da agenda governamental. Cadernos Fundap 1988; 8(15) 103-110.

26. Castro MHG. Governo local, processo politico e equipamentos sociais: um balanço bibliográfico. BIB 1988; $25: 56-82$.

27. Castro R, Bronfman MN. Algunos problemas no resueltos en la integración de metodos cualtitativos y cuantitativos en la investigacion social en salud. In IV Congresso Latino-Americano de Ciências Sociais e Medicina; 1997 Jun 2 a 6; México. Local: Cocoyoc, Mor [mimeografado].

28. Cecilio LCO. Pensando mecanismos que facilitem o controle social como estratégia para a melhoria dos serviços públicos de saúde. Saúde em Debate 1999; v. 23 (53): 30-36.

29. Chioro A, Almeida ES, Zioni F. Politicas públicas e organização do sistema de saúde. Antecedentes, reforma sanitária e o SUS. São Paulo; 1997. [Apostila de curso de gestão de sistemas de saúde]

30. Chirelli MQ. O processo de municipalização dos serviços públicos de saúde em Marilia, SP - 1983 a 1992. Ribeirão Preto; 1995. [Dissertação de mestrado - Escola de Enfermagem da USP].

31. Chorny AH. El enfoque estratégico para el desarrollo ca recursos humanos. Educ Med Salud. 1990; 24 (1).

32. Clarke M, Stewart J Choices for local government for de 1990's and beyond. Harlow Longman; 1991

33. Cohn A. Os governos municipais e as politicas sociais In: Soares JA Caccia-Bava S, organizadores. Os desafios da gestāo municipal democrática. São Paulo: Cortez; 1998 p. 143-192.

34. Conferência Nacional de Saúde, VIII, 1986, Brasilia. Anais. Brasilia: Centro de Documentação do Ministério da Saúde; 1987

35. Contrandriopoulos A, Champangne F, Potvin L, Denis J, Boyle P. Saber preparar uma pesquisa. Definição, estrutura, financiamento. $2^{a}$ ed. São Paulo: Hucitec/Rio de Janeiro:Abrasco; 1997 
36. Costa NR. Políticas públicas, justiça distributiva e inovação. Saúde e Saneamento na agenda social. São Paulo: Hucitec; 1998.

37. Coutinho CN Gramsci/Carlos Nelson Coutinho Porto Alegre L\&PM: 1981.

38. Coutinho CN. Representação de interesses formulação de politicas e hegemonia In: Teixeira SF, organizadora Reforma sanitária: em busca de uma teoria. São Paulo: Cortez/Abrasco; 1989 p.47-60

39 Dowbor L. Prefácio In Rezende J Reforma e politica tributária: as formulaçōes do atual sistema tributário na constituinte de 1987/88. Londrina: Editora Jornal de Londrina: 1998.

40. Elias PEM. Das propostas de descentralização da saúde ao SUS: as dimensões técnica e politico-institucional São Paulo, 1996 [Tese de Doutorado - Faculdade de Medicina da Universidade de São Paulo].

41. Escorel S. Reviravolta na saúde: origem e articulação do movimento sanitário. Rio de Janeiro: Fiocruz; 1998

42 Fadul W. Minha politica nacional de saúde Saúde em Debate 1978; $7 / 8$ (abr/jun): $67-76$

43 Felicissimo JR Os impasses da descentralização politicoadministrativa na democratização do Brasıl Rev. Adm. Empr 1992 $32(1) \cdot 6-15$

44. Ferreira $\mathrm{ABH}$. Novo dicionário da lingua portuguesa. $2^{\mathrm{a}}$ ed. Rio de Janeiro: Nova Fronteira; 1986.

45. Fiori JL. Os moedeiros falsos Petrópolis: Vozes; 1997

46. Fischer $T$ O poder local no Brasil temas de pesquisas e desafios da transição local Rev. Adm. Públ. 1991; 25(2):86-92

47 Fischer $T$, organizador Gestão contemporânea. Cidades estratégicas e organizações locais. $2^{a}$ ed Rio de janeiro Fundação Getulio Vargas; 1997

48. Fleury S, organizador. Saúde e democracia: a luta do CEBES São Paulo Lemos; 1997. A questão democrátıca na saúde, p 25-44

49 Franco TB, Bueno WS. Merhy EE. O acolhimento e os processos de trabalho em saúde: o caso de Betim. Minas Gerais. Brasil Cad Saúde Pública $1999 ; 15(2)$ 345-353. 
50. Franco TB, Merhy EE. Psf: contradições de um programa destinado à mudança do modelo assistencial. Campinas, 2000 (mimeografado).

51. Gerschman S. Sobre a formulação de politicas sociais. In: Teixeira SF, organizadora. Reforma sanitária: em busca de uma teoria. São Paulo: Cortez/Abrasco; 1989. p.119-137.

52. Goulart FAA. Municipalização: veredas. caminhos do movimento municipalista de saúde no Brasil. Rio de Janeiro Abrasco/Conasems; 1996

53. Guimarães Neto L, Araújo TB. Poder local, governos municipais e politicas de indução do desenvolvimento econômico no Brasil. In: Soares JA, Caccia-Bava S, organizadores. Os desafios da gestão municipal democrática. São Paulo: Cortez; 1998. p.9-60.

54. Hobsbawn E. Era dos extremos. O breve século XX. 1914-1991. $2^{\mathrm{a}}$ ed. São Paulo: Companhia das Letras; 1999

55. Hochman G. A era do saneamento. São Paulo: Hucitec/Anpocs; 1998.

56. Huertas F. O método PES: entrevista com Matus São Paulo: Fundap; 1996

57. Jornal do Conasems. Conselho Nacional dos Secretários Municipais de Saúde. Brasilia 2000; Ano 5 (65), ago.

58. Junqueira LAP, Inojosa RM. O processo de municipalização na politica de saúde em São Paulo. Rev . Adm. Públ. 1997;31(5):13052

59. Kisil $M$, Chaves $M$. Programa UNI: uma nova iniciativa na educação dos profissionais de saúde. Battle Creck: Fundação W. K. Kellogg; 1994.

60. Kisil M. Gestão da mudança organizacional. São Paulo: Faculdade de Saúde Pública da Universidade de São Paulo; 1998. (Série Saúde \& Cidadania)

61. Lobato L. Algumas considerações sobre a representação de interesses no processo de formulação de politicas públicas. Rev. Adm Públ. 1997; 31(1):30-48. 
62. López LOJGB. Uma aproximação à avaliação da participação comunitária em SILOS: o projeto UNI - Marilia. São Paulo; 1996. [Dissertação de mestrado -Faculdade de Saúde Pública da USP].

63. Lowi TJ. American business, public policy, case-studies, and political theory. World Politics 1964; 16

64. Ludke M, André MEDA. Pesquisa em educação: abordagens qualitativas. São Paulo: EPU; 1986.

65. Magaldi C. Politicas de saúde no Brasil Londrina: 1995. [Apostila de textos de apoio de politicas de saúde]

65. Maingón T. Las politicas sociales: discusion teorica, conceptual e metodologica. Washington: Centro de intormación y documentación (CID). Programa de desarrollo de polıucas de salud; 1992. (Série informes técnicos, 4 - mimeografado)

67. Marilia (SP). Lei n.3286, de 26 de janeiro de 1988. Autoriza a celebrar convênios com o Governo do Estado de São Paulo objetivando integração dos serviços de saúde que atuam no Municipio e fortalecimento do processo de municipalização. Secretaria Municipal da Administração, Marilia - SP, 26 de jan 1988

68. Marilia (SP). Lei n.02 de 14 de dezembro de 1990. Regulamenta o Conselho Municipal de Saúde. Secretaria Municipal de Administração, Marilia - SP, 14 dez 1990.

69. Marilia (SP). Lei n.07, de 27 de setembro de 1991. Cria o Fundo Municipal de Saúde. Secretaria Municipal de Administração, Marilia - SP, 27 set 1991.

70. Marília. Anais da I Conferência Municipal de Saúde; 1991 set. 27; Marilia, Brasil.

71. Marilia. Prefeitura Municipal. Secretaria Municipal de Higiene e Saúde. Plano Municipal de Saúde; Marilia (SP); 1992

72. Marilia. Prefeitura Municipal. Secretaria Municipal de Higiene e Saúde. Plano Municipal de Saúde. Marilia (SP); 1997

73. Marilia (SP). Decreto n.7527 de 20 de março de 1998. Modifica o decreto n.6326/92, referente às atribuições da divisão de avaliação, controle e auditoria, da Secretaria Municipal de Higiene e Saúde. Secretaria Municipal da Administração, Marilia - SP, 20 de mar 1998 
74. Marilia. Anais da IV Conferência Municipal de Saúde; 1998 mai 2931; Marilia, Brasil

75. Marilia (SP). Lei complementar n.178, de 29 de junho de 1998. Modifica a lei complementar n.7, de 27 de setembro de 1991, que criou o Fundo Municipal de Saúde e dá outras providências. Secretaria Municipal da Administração, Marilia - SP, 29 de jun 1998

76. Matus C. Adeus, senhor presidente: governantes governados $3^{\mathrm{a}}$ ed. São Pau'́: FUNDAP; 1996.

77. Matus C. Politica, planejamento \& governo. $3^{a}$ ed. Brasilia: IPEA: 1997

78. Meirelles HL. Direito municipal brasileiro. $6^{\text {a }}$ ed. São Paulo: Malheiros; 1990

79. Melo MABC. Municipalismo, nation-building e a modernização do Estado no Brasil. RCBS. 1993; 23(8) 85-99.

80. Mendes EV. As políticas de saúde no Brasil nos anos 80. In: Mendes EV, organizador. Distrito sanitário: o processo social de mudança das práticas sanitárias do sistema único de saúde. São Paulo: Hucitec/-Rio de Janeiro:Abrasco; 1993. p.19-91

81. Mendes EV. Uma agenda para a saúde. São Paulo: Hucitec; 1996

82. Mendes EV. A descentralização do sistema de serviços de saúde no Brasil: novos rumos e um novo olhar sobre o nivel local. In: Mendes EV, organizador. A organização da saúde no nivel local. São Paulo: Hucitec; 1998. p.17-55.

83. Miliband R. O Estado na sociedade capitalista. Rio de Janeiro: Zahar; 1972.

84. Mills CW. A Elite do poder. $4^{\mathrm{a}}$ ed. Rio de Janeiro: Zahar; 1981

85. Minayo MCS. O desafio do conhecimento: metodologia de pesquisa social (qualitativa em saúde). Rio de Janeiro; 1989. [Tese de Doutorado - ENSP, Fiocruz].

86. Minayo MCS, Sanches O. Quantitativo-qualitativo: oposição ou complementaridade. Cad Saúde Publ. 1993; 9 (3): 239-262.

87. Minayo MCS. O desafio do conhecimento. Pesquisa qualitativa em saúde $6^{\text {a }}$ ed. São Paulo: Hucitec/Rio de Janeiro: Abrasco, 1999 
88. Moises JA. Poder local e participação popular. In: Dallari $P$, organizador. Política Municipal. $2^{\mathrm{a}}$ ed. Porto Alegre: Mercado Averto; 1986.

89. Muller Neto JS. Políticas de saúde no Brasil: a descentralização e seus atores. Saúde em Debate. 1991; 31: 54-66.

90. Nunes ED. Saúde coletiva: história de uma idéia e de um conceito. Saúde e Sociedade $1994 ; 3(2): 5-21$

91. Oliveira Júniur M. O financiamento da área social e do sistema único de saúde no Brasil. Belo Horizonte; 1998 [apostila do caderno de textos de planejamento e gestão em saúde do Nescon/FM/UFMG]

92 Organización Panamericana de la salud. Formulacion de politicas de salud. Santiago, 1975. (OPAS/Centro Panamericano de Planificacion de la salud).

93. Paim JS. Bases conceituais da Reforma Sanitária Brasileira. In Teixeira SMF, organizadora. Saúde e democracia. A luta do Cebes São Paulo: Lemos; 1997. p. 11-24

94 Paim JS. A Reforma Sanitária e os Modelos Assistenciais. In Rouquayrol MA, Naomar $F^{\circ}$ A. Epidemiologia \& saúde $5^{\text {a }}$ ed. Rio de Janeiro: Medsi; 1999. p.473-487.

95. Paim JS. Políticas de descentralização e atenção primária à saúde In: Rouquayrol MA, Naomar $F^{\circ}$ A. Epidemiologia \& saúde. $5^{a}$ ed. Rio de Janeiro: Medsi; 1999. p.489-503.

96. Projeto UNI: relatório de avaliação do $2^{\circ}$ ano/Faculdade de Marilia...et al./Marilia, 1995.

97. Projeto UNI: relatório de avaliação $3^{\circ}$ ano, julho/95 a junho/96/ Faculdade de Medicina de Marilia.../et al./ - Marilia, 1996

98. Projeto UNI: avaliação dos conselhos locais de saúde, novembro de 1997. Marilia, 1997. [documento encaminhado à coordenação do projeto pelo núcleo de apoio à comunidade - mimeografado]

99. Projeto UNI - Marilia: relatório de avaliação - fase de consolidação $1^{\circ}$ ano, março/97 a março/98/ Faculdade de Medicina de Marilia.../et al/Marilia, 1998

100. Quivy R, Campenhoudt LV. Manual de investigação em ciências sociais. Lisboa: Gradiva; 1992 
101. Rezende J. Reforma e politica tributária: as formulações do atual sistema tributário na constituinte de 1987/88. Londrina: Editora Jornal de Londrina; 1998

102. Rosseau JJ. O Contrato Social. São Paulo: Cultrix; 1975.

103. Roversi-Monaco F. Descentralização e centralização. In: Bobbio N

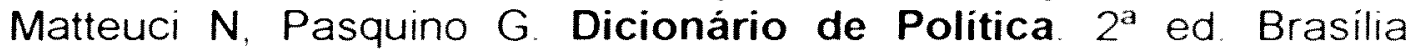
Editora Universidade de Brasilia; 1986 p.329-335.

104. Sadek MTA. Poder local: perspectivas da nova ordem constitucional São Paulo perspect $1991 ; 5(2): 9-15$.

105. Saes D. Democracia. São Paulo: Ática; 1987

106. Salazar-Vargas C. Las politicas pủblicas. Colombia: Pontificia Universidad Javeriana; 1995.

107. Silva Jr. AG. Modelos tecnoassistenciais em saúde. O debate no campo da saúde coletiva. São Paulo: Hucitec; 1998.

108. Silva GGA, Egydio MVRM, Souza MC. Algumas considerações sobre o controle social no SUS usuários ou consumidores? Saúde em debate $1999 ; 23(53): 37-42$

109. Simioni AMC, Lefèvre F, Pereira IMTB. Metodologia qualitativa nas pesquisas em saúde coletiva: considerações teóricas $e$ instrumentais. São Paulo: Universidade de São Paulo. Faculdade de Saúde Pública. Departamento de Prática de Saúde Pública; 1996 (Série monográfica n.2).

110. Singer $P$. Desafios com que se defrontam as grandes cidades brasileiras. In: Soares JA, Caccia-Bava S, organizadores. Os desafios da gestão municipal democrática. São Paulo: Cortez; 1998.

111. Souza C. Reinventando o poder local: limites e possibilidades do federalismo e da descentralização. São Paulo Perspect 1996; 10(3): 103-12.

112. Souza HM. Estratégias para a organização da atenção básica no Brasil. In: Anais da Reunião técnica dos polos de capacitação, formação e educação permanente em Saúde da Familia; 1999 Mai 26-28. Brasilia: Ministério da Saúde. Secretaria de Politicas de Saúde; 2000. p. $13-17$. 
113. Spink MJP. Pesquisa qualitativa em saúde: superando os horrores metodológicos. In: México: IV Congresso Latino-Americano de Ciências Sociais e Medicina.; 1997, Jun 2-6. Local: Cocoyoc, Mor [mimeografado]. Trabalho preparado para orientar a discussão do tema "Metodologias quantitativas e qualitativas nas investigações em saúde: problemas, diferenças e complementaridades".

114. Spitzer RJ. Promotin policy theory. In: McCool DC. Public policy. Theories, models and concepts. New Jersey: Prentice Hall; 1995. p. $233-244$

115. Stein E. Dialética e Hermenêutica: uma controvérsia sobre método em filosofia. In: Habermas J. Dialética e Hermenêutica. Porto Alegre: L\&PM. 1987. p. 98-134

116. Stein RH. A descentralização como instrumento de ação politica e suas controvérsias. Serviço Social \& Sociedade. 1997; 54: 75-97.

117. Stevens GH. The strategic health care manager. San Francisco: Jossey-Bass Publishers; 1991. Responsive Leadership; p. 34-56.

118. Stocker G. The politics of local government Houndmills: Macmillan. 1991

119. Tarride MI. Saúde Pública: uma complexidade anunciada. Rio de Janeiro: Fiocruz; 1998.

120. Teixeira EC. Sociedade civil e participação cidadã no poder local São Paulo; 1998. [Tese de doutorado - Faculdade de Filosofia, Letras e Ciências Humanas da USP].

121. Teixeira SMF. Descentralização dos serviços de saúde: dimensões analiticas. Rev. Adm. Publ. 1990; 24(2): 78-99.

122. Teixeira SMF. A questão democrática na saúde. In: Teixeira SMF, organizadora. Saúde e democracia. A luta do Cebes. São Paulo: Lemos; 1997. p. 25-41

123. Teixeira SMF, coordenador. Municipalização da saúde e poder local no Brasil: relatório de pesquisa. RAP 1997; 31(3):195-298.

124. Triviños ASN Introdução à pesquisa em ciências sociais. São Paulo: Atlas; 1987 
125. Universidade de São Paulo. Faculdade de Saúde Pública. Abordagens metodológicas em politicas públicas. Sä̀ Paulo; 1988. (Cadernos de Pesquisa n. 5).

126. Vianna SM, Piola SF. O financiamento da saúde no Brasil. Brasilia OPAS; 1994. Reavaliando o gasto público em saúde. p. 15-25. (Série Economia e Financiamento, n.4).

127. Vieira L. Cidadania e controle social. In: Pereira LCB, Grau NC, organizadores. O público não estatal na reforma do Estado. Rio de Janeiro: 'GV; 1999.

128. Wanderley LEW. Participação popular, poder local e conselhos São Paulo perspect $1991 ; 5(2): 23-30$ 


\section{ANEXO 1}

\section{INFORMAÇÕES SOBRE OS ENTREVISTADOS}

\author{
DENOMINAÇÃO
}

Gestor 1

Gestor 2

Gestor 3

Gestor 4

Gestor 5

Gestor 6

Gestor 7

Gestor 8

Gestor 9

Usuário 1

Usuário 2

Usuário 3

Prestador de

serviços 1

\section{Prestador de}

serviços 2

Prestador de

serviços 3

Prestador de

serviços 4
FUNÇÕES DESENVOLVIDAS EM MARILIA, EM UM OU MAIS DOS PERIOODOS ANALISADOS

Prefeito.

Secretário de saúde.

Secretário de saúde

Assessor do secretário de saúde

Secretário de saúde

Assessora do secretário de saúde.

Assessor do secretário de saúde.

Diretor da DIR.

Gerente da UBS Coimbra

Conselheira de saúde e representante do componente Comunidade no projeto UNI

Conselheiro de saúde do CMS; conselheiro de CLS do PAS

Planalto; representante dos usuários na congregação e no conselho de curadores da FAMEMA.

Conselheiro do CMS e lider comunitário de favela.

Diretor técnico da Santa Casa de Misericórdia.

Provedor da Santa Casa de Misericórdia.

Diretora-presidente da Maternidade Gota de Leite.

Diretor superintendente da FAMEMA 
Profissional de saúde 1

Médico e diretor executivo da FUMES.

Profissional de

saúde 2

Médica e professora da FAMEMA.

Profissional de

saúde 3

Sindicalista e conselheira do CMS.

Parlamentar 1

Médico e vereador.

Jornalista 1

Jornalista do Jornal da Manhã. 